\title{
AMERICAN CREOLES
}

The Francophone Caribbean and the $\Lambda$ merican South

EDITED BY MARTIN MUNRO AND CELIA BRITTON
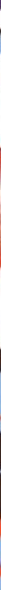

1
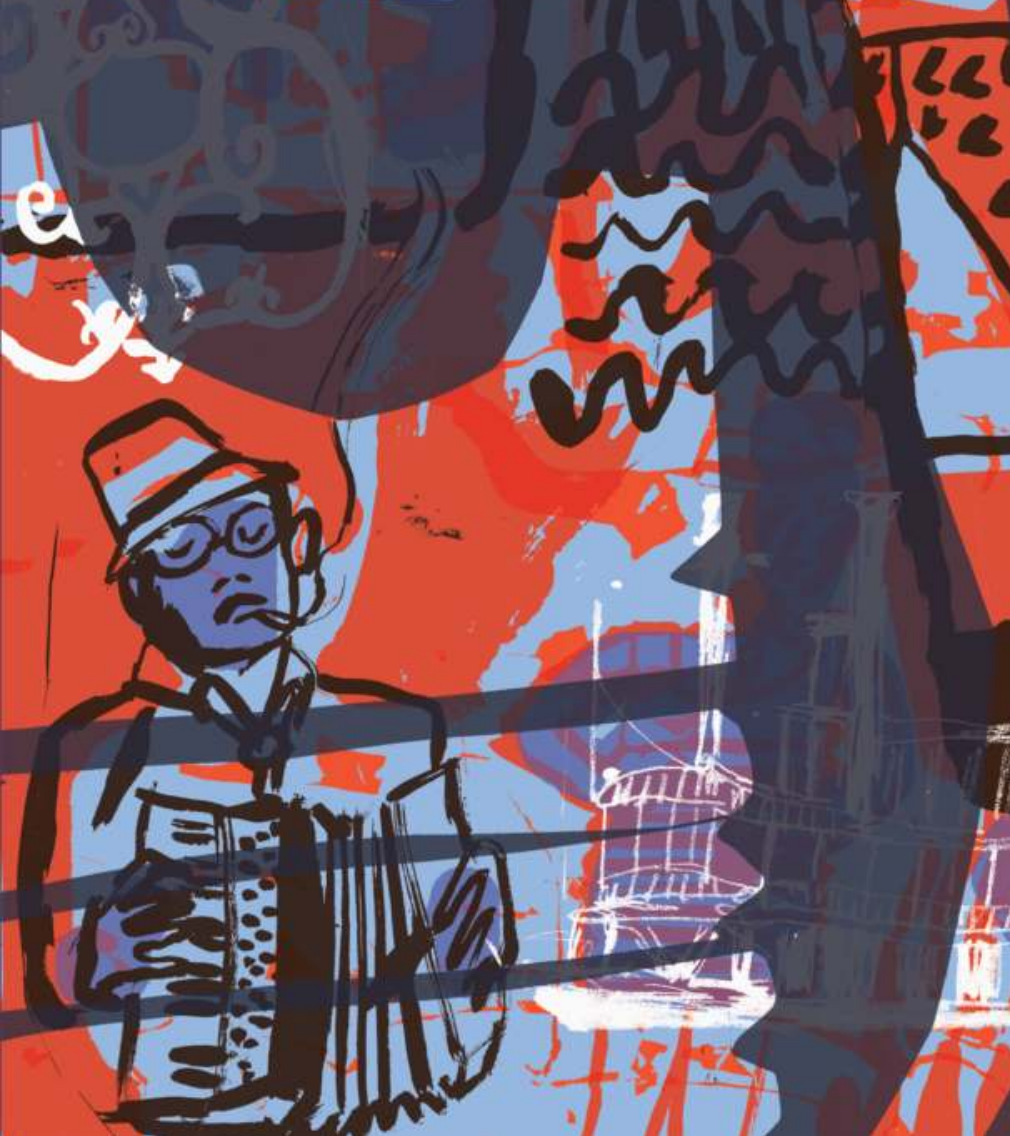

N

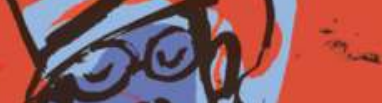

1.

$1 \%$

,
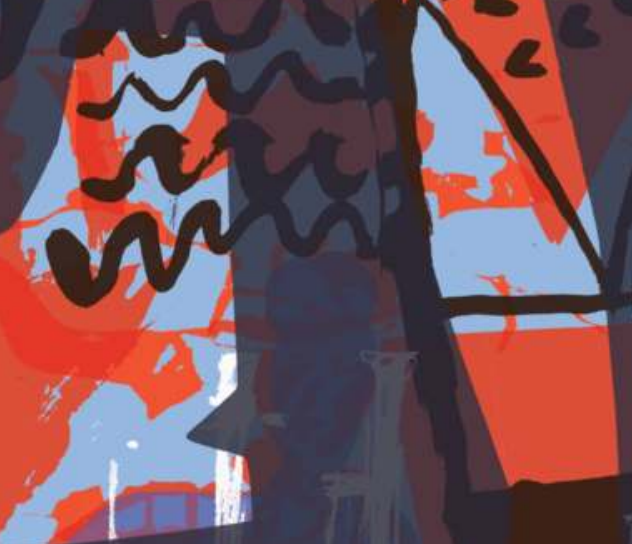

6

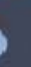

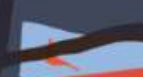




\title{
AMERICAN CREOLES
}

\author{
The Francophone Caribbean \\ and the American South
}




\title{
Francophone Postcolonial Studies
}

\author{
New Series, Vol. 3, 2012
}

The annual publication of the Society for Francophone Postcolonial Studies

The Society for Francophone Postcolonial Studies (SFPS) is an international association which exists in order to promote, facilitate and otherwise support the work of all scholars and researchers working on colonial/postcolonial studies in the French-speaking world. SFPS was created in 2002 with the aim of continuing and developing the pioneering work of its predecessor organization, the Association for the Study of Caribbean and African Literature in French (ASCALF). SFPS does not seek to impose a monolithic understanding of the 'postcolonial' and it consciously aims to appeal to as diverse a range of members as possible, in order to engage in wide-ranging debate on the nature and legacy of colonialism in and beyond the French-speaking world. SFPS encourages work of a transcultural, transhistorical, comparative and interdisciplinary nature. It implicitly seeks to decolonize the term Francophone, emphasizing that it should refer to all cultures where French is spoken (including, of course, France itself), and it encourages a critical reflection on the nature of the cognate disciplines of French Studies, on the one hand, and Anglophone Postcolonial Studies, on the other.

Our vision for this new publication with Liverpool University Press is that each volume will constitute a sort of état present on a significant topic embracing various expressions of Francophone Postcolonial Cultures (e.g., literature, film, music, history), in relation to pertinent geographical areas (e.g., France/Belgium, the Caribbean, Africa, the Indian Ocean, Asia, Polynesia) and different periods (slavery, colonialism, the post-colonial era, etc.): above all, we are looking to publish research that will help to set new research agendas across our field. The editorial board of Francophone Postcolonial Studies invites proposals for edited volumes touching on any of the areas listed above: proposals should be sent to Professor David Murphy: d.f.murphy@stir.ac.uk. Fur further details, visit: www.sfps.ac.uk.

General Editor: Nicki Hitchcott (University of Nottingham)

Editorial Board: Chris Bongie (Queen's University, Canada)

Dominique Combe (Wadham College, Oxford, UK/Paris III, France)

Charles Forsdick (University of Liverpool, UK)

Pierre-Philippe Fraiture (University of Warwick, UK)

Sam Haigh (University of Warwick, UK)

Alec Hargreaves (Florida State University, USA)

Jane Hiddleston (Exeter College, Oxford, UK)

Lieven d'Hulst (KU Leuven, Belgium)

Lydie Moudileno (University of Pennsylvania, USA)

David Murphy (University of Stirling, UK)

Andy Stafford (University of Leeds, UK)

Dominic Thomas (UCLA, USA) 


\title{
AMERICAN CREOLES
}

\section{The Francophone Caribbean and the American South}

\author{
Edited by \\ Martin Munro \\ and \\ Celia Britton
}


First published 2012 by

Liverpool University Press

4. Cambridge Street

Liverpool

L69 7ZU

Copyright @ 2012 Liverpool University Press and the Society for Francophone Postcolonial Studies

The right of Martin Munro and Celia Britton to be identified as the editors of this book has been asserted by them in accordance with the Copyright, Designs and Patents Act 1988.

All rights reserved. No part of this book may be reproduced, stored in a retrieval system, or transmitted, in any form or by any means, electronic, mechanical, photocopying, recording, or otherwise, without the prior written permission of the publisher.

British Library Cataloguing-in-Publication data

A British Library CIP record is available

ISBN 978-1-84631-753-8 cased

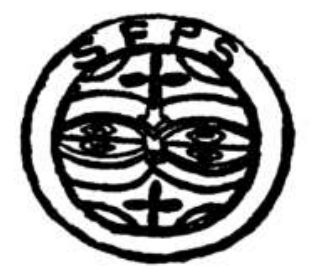

Typeset by Carnegie Book Production, Lancaster

Printed and bound by CPI Group (UK) Ltd, Croydon CR0 4YY 


\section{Contents}

List of Illustrations vii vii

Acknowledgements viii

$\begin{array}{ll}\text { Introduction } & 1\end{array}$

Martin Munro and Celia Britton

\section{Creolizations}

Lafcadio Hearn's American Writings and the Creole Continuum Mary Gallagher

Auguste Lussan's La Famille créole: How Saint-Domingue Émigrés Became Louisiana Creoles

Typhaine Leservot

Caribbean and Creole in New Orleans

Angel Adams Parham

Creolizing Barack Obama

Valérie Loichot

Richard Price or the Canadian from Petite-Anse: The Potential and the Limitations of a Hybrid Anthropology

Christina Kullberg

\section{Music}

'Fightin' the Future': Rhythm and Creolization in the Circum-Caribbean

Martin Munro 
Leaving the South: Frantz Fanon, Modern Jazz, and the Rejection of Négritude

Jeremy F. Lane

The Sorcerer and the Quimboiseur: Poetic Intention in the Works of Miles Davis and Édouard Glissant

Jean-Luc Tamby

Creolizing Jazz, Jazzing the Tout-monde: Jazz, Gwoka and the Poetics of Relation

Jerome Camal

\section{Intertextualities: Faulkner, Glissant, Condé}

Go Slow Now: Saying the Unsayable in Édouard Glissant's Reading of Faulkner

Michael Wiedorn

Édouard Glissant and the Test of Faulkner's Modernism

Hugues Azérad

The Theme of the Ancestral Crime in the Novels of Faulkner,

Glissant, and Condé

Celia Britton

An American Story

Yanick Lahens

Notes on Contributors 


\section{Illustrations}

Fig. 1. La Baraqu' Obama, Sainte-Luce, Martinique. January 2010. Photo courtesy of Anny Dominique Curtius.

Fig. 2. Rue Barack Obama, Le Diamant, Martinique. March 2010. Photo by Valérie Loichot.

Fig. 3. Laurent Valère's Memorial, Anse Cafard, with Diamond Rock in the background. Le Diamant, Martinique. March 2010.

Photo by Valérie Loichot. 


\section{Acknowledgements}

Many of the chapters in this volume were first presented at a conference organized by the Winthrop-King Institute for Contemporary French and Francophone Studies at Florida State University in February 2010. We thank Alec Hargreaves for his generous support, Anthony Cond, David Murphy and Charles Forsdick for their interest in and enthusiasm for this project, and Teresa Bridgeman for her excellent translation work. We dedicate this volume to the memory of Édouard Glissant (1928-2011), whose work has inspired a great number of the essays in this book. 


\title{
Introduction
}

\author{
Martin Munro and Celia Britton
}

There is a curious relationship between the birth of an academic field and its death. In the manifestos and declaration of intent that mark the invention of a field there is often a recognition of its limitations and an intimation of its future demise. In some cases there is even a tacit challenge to bring about and hasten that expiration, or at least quickly to render the field's initial manifestations and conceptual apparatus redundant. Such would seem to be the case with Francophone Postcolonial Studies, a field of study that itself came into being through the end of another, the Association for the Study of African and Caribbean Literature in French. From the first issues of the new society's self-named journal, statements establishing the field and setting its parameters existed alongside self-reflexive critiques that questioned already the durability of many of its founding concepts (see, e.g., Assiba d'Almeida, 2003; Britton, 2003; Harrison, 2003).

This critical self-questioning has been an important and indeed salutary element in the subsequent development of the field. Key works edited by Charles Forsdick and David Murphy have primarily sought to prise open and 'decolonize' the terms 'Francophone' and 'postcolonial': through including France in their investigations of the former term they emphasize the complex, connected relationship between France and its former colonies; while by stressing the importance of French-language works to the postcolonial field more generally they seek to disrupt the almost exclusively anglophone focus of that discipline (Forsdick and Murphy, 2009: 4-5). One of the consequences of the rapid evolution of Francophone Postcolonial Studies and its distinctively self-reflexive nature is that its two constituent terms - Francophone 
and postcolonial - are put under a particular conceptual and semantic stress that seems both to load them with meaning and deprive them of some of their critical usefulness. In a sense, they appear at once to mean too much and too little. Significantly in this regard, the second of Forsdick and Murphy's edited volumes jettisoned the term Francophone in favour of the more neutral 'French-speaking' - a move that acknowledges the ongoing difficulties of dissociating the notion of the Francophone from colonial connotations. It is similarly significant that a further edited work, Transnational French Studies: Postcolonialism and Littérature-Monde, likewise excludes the term Francophone and introduces a new term, transnational, which to some extent shifts the emphasis away from exclusively colonial and postcolonial situations and onto contacts and relations between, across and beyond nations no matter their history. Thus, the more its founding concepts are brought to light, the more they disappear, and the more the field develops, the more it in a sense breaks up. Paradoxically, too, the demise of the field, or at least some of its early incarnations, is a sign of its inherent health.

Our primary intention in this volume is to further this process of productive reinvigoration through directing attention towards a neglected though important dimension of 'Francophone' studies: the relations between the French-speaking Caribbean, including Haiti, and the American South. This shift in focus is prompted by several factors. First, a number of innovative recent works have altered the map of French studies in ways that resituate France into Atlanticist frameworks and asserted the importance of the Americas to French cultural and economic history. Christopher L. Miller's landmark study, The French Atlantic Triangle: Literature and Culture of the Slave Trade (Miller, 2008), provides a timely reminder of the importance of the oceanic circuits of capital and human bodies to hexagonal prosperity and intellectual activity. Because slavery did not take place in France, it has been relatively easy, not to say convenient, to forget it and to leave its many and enduring consequences unacknowledged and misunderstood. Miller's work addresses this historical blind spot and in effect seeks to bring the experiences of slavery, and the social, political and philosophical conditions that allowed it to flourish, out of the shadows of memory and time to which much French political and historiographical discourse has cast them. Building an analytical model that is determined principally by both geography and economics, he shifts his analyses around the three points of the 'French Atlantic triangle' - metropolitan France, West Africa and the Caribbean - and retraces the trajectory that shaped the lucrative commerce between the three Atlantic sites. Miller's particular geographical focus reflects most obviously that of Paul Gilroy, though Miller works still in a largely colonial context and does not incorporate the United States. 
Also, Miller's Atlantic is not exclusively 'black', in that it is concerned as much with Enlightenment-era 'white' literature and philosophy as with the representations of slavery in the work of prominent Francophone Caribbean authors such as Aimé Césaire, Édouard Glissant and Maryse Condé. A closer point of reference - and a further significant influence in recasting the map of French studies - is the work of Bill Marshall and his French Atlantic projects, which do not confine themselves to a triangular shape, but consider more broadly the relationship between France and the Americas. In prising open a broader area of inquiry that emphasizes Franco-American relations in all their diversity and complexity, Marshall redirects critical attention among 'Francophone' scholars to the Americas, inviting us to develop the many fertile areas of investigation that he opens up (Marshall, 2005; 2009).

While Miller and Marshall have opened up this broadly American dimension of Francophone studies, the field of Francophone Caribbean studies has arguably remained more exclusively focused on the two-way relations with Europe, at least in comparison with the rest of the Caribbean. The aim of this volume is therefore to reorient Francophone Caribbean studies and examine in detail the connections between the Francophone Caribbean, including Haiti, and the American South, including Louisiana, which among the Southern states has had a quite particular attachment to France and the Francophone world, being under French rule from 1682 to 1763 and from 1800 to 1803, and having received migrants from Acadia and Saint-Domingue (Haiti) at important points in its history.

These are sites born of the plantation, the common matrix for the diverse nations and territories of the circum-Caribbean. The basic configuration of the plantation, in terms of its physical layout and the social relations it created, was largely the same in the Caribbean and the American South. Such are the similarities that, when Édouard Glissant visited Mississippi and Louisiana, he found himself explaining to Americans the ways in which their world mirrored and echoed his own homeland of Martinique, how the families that fled the French and Haitian revolutions brought a distinctive culture that persists still in various forms: in cooking, in architecture and in music, which are 'principally the same in the culture of this whole area' (Glissant, 1999: 29). The African trace, Glissant says, was kept alive and reconfigured according to the 'inspiration' of particular places in this circum-Caribbean world, a zone shaped by a common, interconnected history that 'travels with the seas' (ibid.). The volume aims to examine these interconnections in depth, and to develop our understanding of the cultural, social and historical affinities between the Francophone Caribbean and the American South.

An important consequence in redirecting the discipline in this way is that it bypasses to a large extent the metropole and reduces greatly the anxiety 
that runs through much of Francophone Postcolonial Studies over the fate of metropolitan France and its apparent inability to come to terms with its colonial past and postcolonial present. This anxiety has tended to deflect attention away from the non-metropolitan, postcolonial world and created an exaggerated sense of France's importance to the postcolonial world, particularly the circum-Caribbean, which encompasses a great variety of territories and states, ranging in historical and political terms from the US South and Haiti, both of which became independent from Europe more than 200 years ago, to the French Overseas Departments of Martinique, Guadeloupe and Guyane. In redirecting Francophone Caribbean studies in the way we propose, we highlight a set of relations that do not require the mediation of France. Taking the French out of Francophone studies liberates the discipline, reduces the significance of France to the 'Francophone world', and shifts the focus away from metropolitan political and social intransigence and onto issues of history, language, politics and 'culture' in more or less tangible forms: for example, literature, dance, music, theatre, architecture, cooking, religion.

In other words, it focuses attention on the notion of 'Creoleness', that elusive, slippery, contested concept that is a peculiarly American invention, a term rooted in, born and indicative of contact between European and African people and cultures in the Americas. Its contested nature is epitomized in the debates it has provoked in the Francophone Caribbean in the past twenty years. The Créolité movement was effectively launched in 1989 with the publication of Eloge de la créolité, which later appeared in a bilingual edition with the English title of In Praise of Creoleness. The principal figures in this movement are the Martinicans Jean Bernabé, Patrick Chamoiseau and Raphaël Confiant. Créolité centres on a belief in the importance of Creole language and culture, and an interest in the processes of creolization. Like Glissant, the Créolité group challenges the traditional, colonially inherited mimetic impulses in French Caribbean culture. Whereas they cite Glissant as an important influence, they have posed a very direct challenge to Aimé Césaire and négritude. Because Césaire wrote only in French, they say, he neglected the island's 'authentic' language, and the rich oral tradition. In their turn, however, the Creolists and their doctrine of Créolité have been criticized for their apparent desire to fix Antillean identity in their new, essentialized version of Creoleness. Critics say that, unlike Glissant, the Creolists have underplayed the evolving, non-teleological elements of creolization, and sought to ground identity once more in a new oneness. Perhaps the most strident critic of the Creolists has been Maryse Condé. She argues that the Martinican school of Créolité 'is singular because it presumes to impose law and order', and in implying a notion of 'authenticity', which inevitably 
engenders exclusion, as "authenticity" is based on the very normative ideology that for so long consigned us to the world's periphery' (Condé, 1998: 106). Like Condé, this volume promotes an idea of Creole culture and creolization as open-ended, non-prescriptive phenomena. Like Sidney Mintz and Sally Price in Caribbean Contours, we insist that the terms remain some of the most useful for conceiving the circum-Caribbean as a cultural and historical unit, an overarching, polyvalent and malleable concept that does not deny internal diversity and difference, but which indeed incorporates these as constituent elements of Creole societies and cultures (Mintz and Price, 1985: 6). The book's chapters are organized into three sections (under the headings Creolizations, Music, and Intertextualities: Faulkner, Glissant, Condé) that group the essays thematically, though our objective is that the sections and chapters be read not in isolation but comparatively, as particular inquiries into topics that are fundamentally related.

\section{Creolizations}

Many of our contributors comment on the semantic instability of the term 'Creole': it has had a complex history, from designating the original white settlers of Louisiana to the potentially worldwide Glissantian dynamic of creolization. There is also a connection to be made between this linguistic indeterminacy and the hybridity and fluidity that are so prominent in its referent - Creole culture itself. As a cultural identity, 'Creole' seems to be definable only as a shifting set of differential terms which depend upon the particular context: French-versus English-speaking, mixed-race versus either black or white, culturally as opposed to biologically defined racial identity, and so on. Thus, Angel Adams Parham, for instance, groups her Creoleidentifying interviewees according to the term that they define themselves against. In a rather different sense, however, binary oppositions are also deeply antipathetic to Creole culture. One of its most prominent features is its three-tiered racial classification as opposed to the Anglo-American binary black-white divide. Similarly, the characters of the play analysed by Typhaine Leservot are shown as building an identity as American citizens of Louisiana in opposition to both revolutionary Saint-Domingue and revolutionary France.

The chapters in this volume that deal explicitly with definitions of Creole culture and Creole identity discuss a wide range of types of text: journalism, ethnography (amateur and professional), interviews, drama, novels, political slogans, autobiography. This generic hybridity is indeed often in evidence within the work of one particular figure. Mary Gallagher's analysis of Lafcadio Hearn's writing on nineteenth-century Louisiana and Martinique 
shows how it veers from journalism to a kind of proto-ethnography (in his descriptions of popular culture, and his published collections of Creole folk-tales, songs, etc.) to fiction: he also wrote two novels, one set in Louisiana and one in the Caribbean. Gallagher shows how for Hearn Louisiana and the French-speaking Caribbean form a 'Creole continuum' that disregards national boundaries; and how even this continuum lacks clear boundaries, as Hearn's writing on black communities in Cincinnati reveals the similarities between these communities and those that he defines as strictly Creole. She stresses his long-standing fascination with Creole culture: not only his intense intellectual investment in Creole issues but also - despite his always positioning himself as an outsider - a strong emotional attraction and aesthetic delight that, she suggests, result in his production of imaginative literature as well as quasi-ethnographic journalism. It is above all the phenomenon of racial mixtures that fascinates him: the aesthetics of skin colour and the 'depth of the inter-ethnic and inter-linguistic palimpsest that distinguished post-plantation culture' (29).

Staying with nineteenth-century Louisiana, Leservot's analysis of Auguste Lussan's 1837 play La Famille créole has a very different emphasis. It is more explicitly concerned with the mechanisms of a construction of collective identity, and less in relation to racial differences (except in so far as these are carefully excluded by the play) than in terms of an emerging national American identity. Leservot notes the importance of theatre as a forum for identity politics in the 1830 s, when Louisiana was still regarded with some suspicion by the rest of the United States. A major factor in this was the influx of refugees fleeing the revolution in Saint-Domingue, of which Lussan's 'Creole family', the Clairvilles, are an example. The play is set in 1794, and opens with the Clairvilles' arrival in New Orleans, having abandoned their land and their wealth in Saint-Domingue. Rather than staying in America, however, they plan to settle in France, but get caught up in the French Revolution, are nearly guillotined, and return to Louisiana, which now assumes the status of a safe American haven for innocent victims of political persecution. Leservot shows how the journey to France and back is an essential stage in the play's manoeuvring of the Clairvilles into a position where they identify with America rather than France and are politically acceptable as American citizens. The way in which the French Revolution is superimposed on the Haitian one allows the latter to disappear: as victims, the Clairvilles can be presented not as slave-owning colonial planters but as innocents wrongfully accused of treason, neither revolutionaries nor royalists. Thus divested of any inconvenient allegiances, they are ready to become American citizens.

Angel Adams Parham's 'Caribbean and Creole in New Orleans' is an ethnographic study of the continuing significance of the Saint-Domingue 
refugees in the present-day racial identifications of the Creoles of New Orleans. At the time of this migration Louisiana, because of its distinctive colonial history, was far more racially tolerant than the rest of America, and its large mixed-race community - the free people of colour - included individuals of considerable wealth and status; but all of this had been under threat since the Louisiana purchase in 1803. The refugees from Saint-Domingue more than doubled the numbers of the free people of colour in New Orleans and so helped the community resist the pressures of the American binary racial divide and retain its Creole culture. Parham's interviews with descendants of the refugees demonstrate their continuing awareness of the Caribbean component of their ancestry, and their feelings of affinity with the Caribbean. But she also distinguishes four 'cultural scripts' in which their self-identifications as Creole are formed by differentiating between themselves and, for the white subjects, either 'Américains' or the binary black-white divide, and for coloured subjects, either in opposition to or as part of the wider community of African Americans. This approach reveals the mobility of the signifier 'Creole'; it allows the complexity of racial and ethnic identities in Louisiana to emerge; and it also emphasizes the extent to which racial identification is not a biological given but a discursively constructed choice of a particular cultural script.

Valérie Loichot's analysis of representations of Barack Obama in France, the USA and Martinique moves the discussion of 'Creoleness' out of Louisiana but places an even more explicit emphasis on the cultural, as opposed to biological, nature of racial identity. She does this by contrasting biological 'métissage' (with its etymological roots in plant-breeding) with 'creolization'; in Glissant's sense of unpredictable cultural contact and exchange, 'métissage' stabilizes and creolization destabilizes racial constructs. Most French journalists describe Obama as a 'métis', while in Martinique he is referred to as 'créole'. Thus the French press essentializes Obama's racial identity; it does so, moreover, with a concept that is completely foreign to American definitions of race: in the binary opposition of the 'One-Drop Rule', the 'métis' corresponds only to the pejorative 'half-caste'. Conversely, the appellation 'African American' is not used by the French, because it transgresses the republican principle that citizenship is independent of ethnicity. These mismatches illustrate the 'untranslatability of race' between different national cultural discourses. But, in any case, Obama is not African American in the dominant sense of being a descendant of slaves. Since neither 'métis' nor 'African American' can satisfactorily define him, Loichot argues we must turn away from fixed biological or historical determinations and look at the freer identifications made possible by creolization. During his election campaign, the Martinicans enthusiastically adopted Obama as one 
of themselves: Loichot cites a video of him dubbed into Creole in which he is made to say 'Moin cé un Matinikè' [I am a Martinican]. Obama is a Creole precisely because of his racial indeterminacy - 'his complex cultural, familial and racial diversity impossible to fix in one static definition' (88). Moreover, he is an agent of creolization through the chosen identifications of which he is both subject and object.

Christina Kullberg's chapter on Richard Price also focuses on Martinique, and brings together two themes that we have encountered in previous chapters: the hybridity of Creole culture and the ethnographic perspective. But she is most centrally concerned with another characteristic of Price's The Convict and the Colonel, one which is curiously similar to Lafcadio Hearn's writing a century earlier. Unlike Hearn, Price is a professional anthropologist; like him, however, Price's writing is, some of the time, openly subjective and emotionally involved with a Martinican culture that he is not only observing but to which (unlike Hearn) he also claims to belong. If Price's book thus combines anthropology and autobiography, it does so of course with a sophisticated reflexive awareness that is entirely lacking in Hearn's naively expressed attachments and prejudices. Indeed, Price is consciously participating in an ongoing debate within his discipline as to the validity of so-called postmodern anthropology, whereas Gallagher attributes Hearn's love of Creole culture to his own personal history of mixed Greek-Irish descent and childhood displacement. But they have in common, beyond the basic incorporation of affect into conventionally impersonal ethnographic description, a strong nostalgia for Creole cultures that they both see as disappearing: what Gallagher sees as Hearn's 'antiquarian' perspective is not all that far removed from Price's critique of the trivialization and commodification of cultural memory in a rapidly modernizing Martinique. Equally, Price's book develops in a far more deliberate fashion the generic diversity of Hearn's mixture of reportage, aesthetic appreciation and fiction; it combines anthropological analysis with travel writing and imaginative reconstruction (of, for example, the convict's years in French Guyana, of which there is very little documentation). One major difference between the two writers is that while Hearn always maintains the role of observer of a foreign culture, Price adopts a stance of emotional involvement with his Martinican subjects and writes as a participant in, as much as an observer of, their community, alternating between intimacy and distance to produce the 'staging of a distance which is then superseded' (101). Kullberg argues that the 'poetic' qualities of Price's anthropological narrative work to inhibit a fixed view of the other, and ultimately relates this lack of fixity to the nature of Creole culture itself. That is, she concludes that the reason for the hybridity of his discourse is not so much a move in a scholarly debate on the status of anthropological knowledge 
as it is a recognition and replication of the heterogeneous nature of Creole culture itself and the difficulty of capturing its elusive reality: 'a representation of Creole society which can itself be described as creolizing' (105).

\section{Music}

This notion of a creolized and continually creolizing cultural sphere across the circum-Caribbean is developed and expanded in four chapters - by Martin Munro, Jeremy Lane, Jean-Luc Tamby and Jerome Camal - that focus on the particular contributions of music and musicians. Music appears as a distinctively fluid and effective conduit for the kinds of non-hierarchical exchanges that creolization thrives on. Munro's essay deals specifically with rhythm and starts from the idea that European colonists in the plantation world created anti-rhythmic societies that lacked the basic rhythmic socialization (a common, functional understanding of time, culture and work) that has been a fundamental element in bonding communities from the beginning of human history. As Munro argues, however, among the enslaved people more organic and benign rhythms persisted and helped them survive the plantation and its anti-rhythmic foundations. A crucial aspect of Munro's thesis is that rhythm was not the property of one group, and that it became one of the most effective means of transgressing social and racial divides and in creating the unique social order and culture of the circum-Caribbean. The chapter examines some of the ways in which rhythm has functioned and continues to serve as a particularly malleable and persistent social and cultural element both in the Caribbean and in the American South. The initial focus is on James Brown's rhythmic innovations in the 1960s, and Brown's interpretation of his rhythms not as echoes of a recoverable racial past but as pre-echoes of the future, and of sounds and ways of thinking yet to be realized. The chapter discusses Brown's rhythms in relation to other instances in Haiti, Martinique and Trinidad where rhythm has been a prominent factor in moments of social and personal transformation. Rhythm, Munro argues, has been a primary force in creating these creolized societies, and remains a dynamic element of the circum-Caribbean world.

Jeremy Lane writes on Frantz Fanon, a figure not normally associated with creolization or with circum-Caribbean cultural relations. As Lane shows, however, Fanon's interest in one prominent manifestation of creolized American culture - jazz music - formed an important, if neglected, part of the Martinican's critique of Romantic interpretations of black cultures in the Americas. Arguing that Fanon's biographer David Macey misunderstands and underestimates the significance of Fanon's allusions to jazz, Lane calls into question Macey's assumptions about ethnic or national identity and the 
particular cultural forms appropriate to that identity. He similarly questions Françoise Vergès's critique of what she sees as Fanon's 'disavowal' of the 'reality' of his Creole identity, in favour of a reinvention of his 'filiation' and 'symbolic ancestry in Algeria' (Vergès, 1997: 579). As Lane sees it, Macey's and Vergès's critiques are underpinned by fundamentally Romantic ideas about the organic relationships between ethnic identity, bounded geographical location and their associated forms of cultural and linguistic expression. Ironically, as Lane shows, Fanon's scattered allusions to jazz show him attempting precisely to question and re-formulate each of those Romantic assumptions, chiefly through the Martinican's critique of Léopold Sedar Senghor's conception of négritude. In his early essays and poems, Senghor had presented jazz as an important expression of négritude, that is to say of an essentialized nègre identity, rooted in the unchanging rhythms of an organic rural community, of which West Africa was the archetype and the American South its faithful reproduction in the New World. As Lane shows, Fanon's allusions to jazz form an integral part of the Martinican's critique of Senghor's négritude and, as such, involve Fanon seeking to uncouple jazz's potential cultural and political significance from any organic links the music might be assumed to possess either to essential racial identity or to its putative geographical place of origin in the American South.

Jean-Luc Tamby carries out a music-based comparison of two figures that are rarely discussed together: Édouard Glissant and Miles Davis. Davis is not conventionally associated with the South - indeed, he seems to illustrate Fanon's critique of the essentialist association of jazz and the South - but Tamby's comparison of his and Glissant's aesthetics makes many telling connections between the two that implicitly expand the boundaries of the circum-Caribbean into the Northern states to which many African Americans migrated from the South during the twentieth century. Basing his analysis on a statement made by Glissant that his writing style is virtually the same as Davis's jazz style, Tamby asserts that the literature of the Caribbean and jazz music in the United States belong to areas of cultural activity which have comparable histories, despite their dissimilarities. Tamby's comparative approach to the two artists leads to reflections on their common 'strategies of resistance' and their individual formal concerns. Style and rhythm are Tamby's primary areas of interest - means of bridging historical differences between Caribbean literature and African American music. As Tamby argues, Glissant's concepts of langage and the (African) trace bring together different cultural phenomena within a single community and connect groups with a common history of slavery and colonialism but which are separated by either geography or linguistic differences. Glissant similarly conceives of an aesthetic community that joins several artistic disciplines, and, as Tamby 
says, style in this case has a primarily collective value. Careful analyses of the rhythmic qualities of Glissant's and Davis's work lead Tamby to conclude that the power of the artists' rhythms cannot be reduced to their shared history, and that through rhythm they manage to escape the confines of history and attain a style that transcends their place in time, reaching perhaps a kind of ultimate destination of creolization, a space that incorporates all of history yet is freed from it.

Jerome Camal's essay similarly employs Glissantian concepts to frame its analyses of circum-Caribbean musical forms. Camal reflects on musicological debates concerning the usefulness of the concept of creolization in globalization studies as a means of emphasizing the fluid and unstable nature of culture, and in postcolonial studies as a marker of the putative creative ingenuity of 'subaltern and deterritorialized peoples' (Khan, 2007: 237). Noting that a number of anthropologists have argued that the historical process of creolization in the Caribbean has been fundamentally different from contemporary processes of globalization, and that creolization not be divorced from its original historical and geographic contexts, Camal sets out to test the usefulness of creolization through a study of American saxophonist David Murray's collaboration with Guadeloupean musicians. Drawing on written, ethnographic and musical sources, Camal compares musicological understandings of Glissant's créolisation with the meaning of creolization for the musicians involved in the Creole Project in Guadeloupe. Camal shows that 'creolization' - and its related terms 'Creole' and 'Créolité' - continue to hold specific and disputed meanings in Guadeloupean society, which render difficult their wider application as concepts capable of describing global processes of cultural exchange or identity formations.

\section{Intertextualities: Faulkner, Glissant, Condé}

Glissant also figures centrally in three chapters in this volume which are concerned with his work on William Faulkner; in other words, the connections between the American South and the French-speaking Caribbean are also embodied in the relationship between two of their greatest writers. Glissant's admiration for Faulkner is evident throughout his career, culminating in the book Faulkner, Mississippi (1996), which he wrote while he was himself living in the American South, teaching at Louisiana State University in Baton Rouge. This book, whose title immediately proclaims the importance of Faulkner's affiliation with the South, is the subject of the chapters by Michael Wiedorn, Hugues Azérad and Celia Britton. Azerad emphasizes the impact that Faulkner, Mississippi had on existing critical assessments of Faulkner, both in its original form and in the English translation that 
came out three years later, in 1999. Whereas Faulkner had previously been valued on formalist, aesthetic grounds for the modernist obscurity of his writing technique, he had also been castigated for his loyalty to the reactionary attitudes of the traditional white South and his tolerance of its racism; the idea that he could have a positive influence on African-American and Caribbean writers would have seemed ridiculous and even offensive. This, however, is what Faulkner, Mississippi very controversially proposes: Glissant in effect reclaims Faulkner as a 'Creole' writer and argues that his novels are, ultimately and perhaps despite themselves, politically progressive in their intuition of the possible future creolization of American society. Wiedorn shows how Glissant's view of Faulkner derives from his more general conviction that all writers belonging to the post-plantation societies of the circum-Caribbean, whether they write in English, Spanish, French or Portuguese, have a common 'langage', or way of using language - and that this 'langage' is characterized by one of Glissant's most important concepts: opacity. ${ }^{1}$ As Wiedorn puts it, 'a literary method characterized by paradox and contradiction is necessitated by the particularity of this place or group of places' (183). Faulkner shares this 'langage'; in fact, Glissant at one point suggests, even more contentiously, that he originated it and that other writers such as Carpentier, Wilson Harris, Césaire and Glissant himself 'borrowed' it from him. The obscurity of Faulkner's style, therefore, has less to do with European modernism than with his roots in a Creole plantation culture; and his novels' refusal to render their black characters transparent to the reader is a form of respect for their difference. But Wiedorn goes on to argue that the importance of opacity for Glissant is that it has the potential to extend far beyond Creole societies. It becomes a creative force in all literature, producing new genres and styles. But nor is it simply a literary technique: as the recognition of the unknowable dimension of the other, it is also both an epistemological and an ethical concept. As such, it allows Glissant to present literature as 'the final revelation of the other as concealed and unknowable finally' (189). Equally, this means that Faulkner's opacity bestows on his writing an ethical relationship to the other that outweighs the reactionary stance of Faulkner qua private citizen.

It will be clear from the above that Glissant's perspective on Faulkner is closely bound up with his own literary work, and his own ideas on literature in general. This relationship is developed more explicitly by Azérad, who sees Faulkner, Mississippi as a 'mirror structure in which the work of each

1 In a chapter of Poétique de la relation entitled 'Lieu clos, parole ouverte' Glissant derives this deliberate use of obscurity and indirect meaning from the slaves' need to hide their culture from their masters (Glissant, 1990: 82-83). 
author would be tested out by that of the other' (201). It is through his reading of Faulkner, in other words, that Glissant can test out his own 'poetics of Relation' as a new form of thought and literary criticism. For Azérad, Faulkner's affinity with Creole society is based on the loss of history that both suffer from, although the loss is not identical: the historical void created by transportation and slavery that resonates through Glissant's work is put in parallel with Faulkner's obsession with the original crime of the American South, namely the unacknowledged stain of slavery that vitiates the attempt to found a legitimate lineage. In both cases, but from opposite sides, the institution of slavery causes an 'abyss' preventing both historical memory and historical progression.

But it is on the issue of Faulkner's modernism that Azérad sees the most far-reaching connection with Glissant's own work. Modernism is not a central term in Glissant's thought; but to the extent that it is commonly opposed to realism, and therefore sometimes seen as antagonistic to more straightforwardly political postcolonial fiction, it is highly relevant to his insistence that realism is an inadequate genre for expressing the opaque, 'unsayable' realities of Creole culture. Azérad compares Glissant's position with Adorno's theorization of 'modernist negativity', that is, the idea that it is precisely the autonomy of the modernist work of art, its refusal simply to imitate existing reality, that guarantees its 'truth' and its ability 'out of the depths of its negativity, to restore a form of hope to the world' (205). Modernism's refusal to represent is the negative moment of a dialectic which brings about future change. For Glissant, too, Azérad points out, the 'Negator' - the figure who refuses to accept society as it is - is a central value; and this can be linked to Glissant's belief that it is the 'literariness' of literature rather than its capacity for accurate realistic representation that gives it the potential to be a political force.

Celia Britton's chapter is not concerned exclusively with Faulkner, Mississippi but uses it as a framework within which to examine Faulkner's influence on two Caribbean novels: Glissant's Le Quatrième Siècle (1964) and Maryse Condé's Traversée de la mangrove (1989). Whereas the opacity of both Faulkner and Glissant is defined by Wiedorn as the foundation of an ethics of alterity, and by Azérad as the 'positive negativity' of a politically relevant modernism, Britton sees it rather differently as, in Faulkner's case, stemming from an unresolvable, largely unconscious contradiction in his attitude towards the white South and, in Glissant and Condé, a very conscious authorial representation of a different kind of repression or deferral of meaning on the part of the characters. Rather as in Azérad's account the abyss of history takes different but parallel forms in Faulkner's and in Glissant's novels, so for Britton the structure of repressed meaning 
operates on different but parallel levels in their writing (and in that of Condé).

Britton sets Faulkner, Mississippi in the context of Glissant's more general discussions of the opposing principles of creolization and 'filiation', and his claim that Faulkner's novels are dominated by his sense of the 'damnation' of the South, that is, the crisis of filiation that stems from the crime that lies at its origins. Although this crime is usually taken to be the institution of slavery, Glissant shows how Faulkner never states this explicitly, and how it generates narrative structures in which a shameful secret buried at the origin of the novel is revealed only gradually, as though reluctantly, and incompletely. Britton analyses this deferred and/or concealed meaning in Machereyan terms as the text's determination by 'what it cannot say'; Faulkner's opacity is compulsive, and he is not wholly in control of his writing. Glissant, in contrast, constructs Le Quatrième Siècle more lucidly around a similar crime at the root of a lineage and mimics the long-delayed revelation of this secret as an expression not of the guilt of the slave-owners but the shame of the slaves - but also shows how in contemporary creolized society such questions of lineage and ancestral crimes have become irrelevant. Condé, similarly, organizes the narrative of Traversée de la mangrove so that the repressed awareness of slavery as it were bursts through to the surface of the novel only at the end; she also provides a clearly ironic reworking of the Faulknerian themes of the ancestral crime, miscegenation and incest.

Glissant's reclamation of Faulkner - despite the latter's ambivalent, even reactionary, ideas on race - as a 'Creole' writer ultimately indicates some of the paradoxes involved in relations between the American South and the Caribbean. Writers and artists from the Caribbean are often both repelled by the South and irresistibly drawn towards it. As the short piece of fiction 'An American Story' by the Haitian author Yanick Lahens shows, the South figures in Caribbean writing as a bastion of white racism, an often nightmarish world of segregation and fear. Set in 1963, it tells of a journey made by the Haitian narrator and her American companion through the South, a journey that feels like a trip to 'an abyss from which a Black person in those years could only return banged up or dead' (231). The South, to the narrator, with the Ku Klux Klan and the John Birch Society still powerful forces, is 'like a big trap'. Her experiences in the South lead her to reflect on Haiti's contemporary experience of dictatorship, to find some consolation in Haitian history, and the banishment of white rule from her country. Of colonial history, she says, Haiti 'bore only the scars. Today, we witness our own errors, our own grandeur and weaknesses. We pay the price dearly, but they are ours' (232). As Lahens's story demonstrates, the South is a site in which Caribbean people are emotionally and historically invested; the struggles of 
the South echo those of the islands, which have their own particular ongoing tensions around class and colour. From a Caribbean perspective, the South appears almost like a distant branch of the same family, connected by blood and history. Aimé Césaire expresses such a Caribbean view of the South in the following passage from Cahier d'un retour au pays natal:

Qui peut se vanter d'avoir mieux que moi? Virginie.

Tennessee. Géorgie. Alabama

putréfactions monstrueuses de révoltes

inopérantes

marais de sang putrides

trompettes absurdement bouchées

terres rouges, terres sanguines, terres consanguines.

(Césaire, 1983: 25)²

Césaire's evocation of these four Southern states as monstrous, putrefying products of 'révoltes inopérantes' [stymied revolts] seems to suggest the failure of the American Revolution or indeed the Civil War to establish racial equality there. These are to Césaire, and to many other Caribbean artists, nightmarish places, bogged down in the putrid swamps of history. As he suggests, it is as if the land itself is soaked in blood, and bleeds still. Strikingly, though, the abject, repulsive South is not only a 'sanguine' land; these are also 'terres consanguines', that is, lands connected by blood to Césaire's own. The blood of history thus attaches the Francophone Caribbean to the South and creates an enduring bond and a sense of common destiny that continue to be dynamic elements in the ongoing evolution of this Creole, creolizing world.

\section{Works Cited}

Assiba d'Almeida, Irène. 2003. 'A Necessary Uneasiness'. Francophone Postcolonial Studies 1.1: 25-28.

Bernabé, Jean, Patrick Chamoiseau, and Raphaël Confiant. 1989. Éloge de la Créolité. Paris: Gallimard.

Britton, Celia M. 2003. 'New Approaches to Francophone Literature'. Francophone Postcolonial Studies 1.1: 29-32.

Césaire, Aimé. 1983 [1939]. Cahier d’un retour au pays natal. Paris: Présence africaine.

2 'Who can boast of being better off than I? Virginia. / Tennessee. Georgia. Alabama / monstrous putrefactions of stymied / revolts / marshes of putrid blood / trumpets absurdly muted / land red, sanguineous, consanguineous land' (Eshleman and Smith, 1983: 47). 
Condé, Maryse. 1998. 'Créolité without the Creole Language?'. In Kathleen M. Balutansky and Marie-Agnès Sourieau (eds), Caribbean Creolization: Reflections on the Cultural Dynamics of Language, Literature, and Identity. Gainesville and Kingston, Jamaica: University Press of Florida/University of the West Indies Press: 101-09.

Eshleman, Clayton, and Annette Smith (trans.). 1983. Aimé Césaire, The Collected Poetry. Berkeley: University of California Press.

Forsdick, Charles, and David Murphy (eds). 2009. Postcolonial Thought in the French-Speaking World. Liverpool University Press.

Glissant, Édouard. 1990. Poétique de la relation. Poétique III. Paris: Gallimard. —. 1996. Faulkner, Mississippi. Paris: Stock. English translation by Barbara B. Lewis and Thomas C. Spear, Faulkner, Mississippi, 2000 [1999], Chicago, IL and London: University of Chicago Press.

Harrison, Nicholas. 2003. 'Postcolonialism and the Object of French Studies'. Francophone Postcolonial Studies 1.1: 42-48.

Khan, Aisha. 2007. 'Creolisation Moments'. In Charles Stewart (ed.), Creolization: History, Ethnography, Theory. Walnut Creek, CA: Left Coast Press: 237-53.

Marshall, Bill. 2005. France and the Americas: Culture, Politics and History. 3 vols. Santa Barbara, CA; ABC-CLIO.

-. 2009. The French Atlantic: Travels in Culture and History. Liverpool University Press.

Miller, Christopher L. 2008. The French Atlantic Triangle: Literature and Culture of the Slave Trade. Durham, NC and London: Duke University Press.

Mintz, Sidney W., and Sally Price. 1985. Caribbean Contours. Baltimore, MD: Johns Hopkins University Press.

Vergès, Françoise. 1999. Monsters and Revolutionaries: Colonial Family Romance and Métissage. Durham, NC and London: Duke University Press. 


\section{Creolizations}





\title{
Lafcadio Hearn's American Writings and the Creole Continuum
}

\author{
Mary Gallagher
}

Les écrivains, de plus en plus, auront du mal à tracer leurs frontières. Signalons pour mémoire le cas extraordinaire de l'écrivain anglo-hellène, de nationalité américaine, Lafcadio Hearn qui, à la fin du XIX ${ }^{e}$ siècle, recueillit les contes créoles de Louisiane et de la Martinique, vécut avec délices dans le Saint-Pierre d'avant l'éruption, publiant également des ouvrages pleins d'amour pour les paysages et les hommes martiniquais, paraissant un instant s'enraciner ici-là, avant de partir pour le ... Japon où il épousa une femme du cru et écrivit des ouvrages en japonais. Homme à l'identité multiple, Lafcadio Hearn a eu l'intuition de la Diversalité. ${ }^{1}$

Patrick Chamoiseau and Raphaël Confiant, Lettres créoles: tracées antillaises et continentales de la littérature, 1635-1975, pp. 169-70

\footnotetext{
1 'More and more often, writers will find it difficult to define the limits of their identities. We could quote from memory the extraordinary case of the Anglo-Greek writer of American nationality, Lafcadio Hearn, who, at the end of the nineteenth century collected the Creole folktales of Louisiana and Martinique, who lived with delight in pre-eruption Saint-Pierre and who also published works full of affection for the Martinican landscapes and peoples; Hearn seemed even to settle over here, before leaving for ... Japan, where he married a local woman and wrote books in Japanese. As a man of multiple identities, Lafcadio Hearn had a premonition of "diversality"'.
} 


\section{Lafcadio Hearn's Creole (Pre)Disposition}

Lafcadio Hearn (1850-1904) is famous principally for having 'interpreted' Japan for the West in the closing years of the nineteenth century. Even if his life and work are recognized as falling into two main periods, the American and the Far Eastern, the latter is usually seen as outshining the former. It is less, however, the work of Hearn's Japanese period than the inscapes of his American/Caribbean writings that hold the key - if not to the overall significance, then certainly to the contemporary resonance of this unusual fin-de-siècle figure and of his work. These writings are clearly founded on what one might call a Creole gravitation. The object of this study is to show how the expression of Hearn's apparently inexorable Creole tropism illustrates a profound post-plantation cultural continuum which links the American Deep South to the Caribbean basin and also points forward to contemporary paradigms of cultural crossing, palimpsest or (as the authors of my epigraph put it, in a performative neologism) 'diversalité'.

Not only does the idea of cultural continuum have, according to that epigraph, contemporary and universal purchase, but it is originally associated with specifically Creole spaces. The epigraph is a quotation from Lettres créoles, a literary survey of 'Creole literature' co-authored by two contemporary Martinican authors, Patrick Chamoiseau and Raphaël Confiant. Emphasizing the notion of continuum as a denial or cancellation of borders, the two Martinicans claim that it is becoming more and more difficult to 'confine' writers of the contemporary age within a single, simple label. Their complex identities and their mobility defeat efforts to contain them within the boundaries set by a single national, ethnic or cultural tradition. In that sense, the authors of Lettres créoles claim Hearn for Creole letters, identifiying him as having been almost a century ahead of his time. His refusal, or failure, to settle within (or for) just one place, culture, nationality, language etc. illustrates the extent of his engagement with cultural interrelation or 'diversalité', an engagement to which he may appear to have been predestined by the plurality of his mixed family origins and by the instability of his childhood and early life.

In his preface to a recent edition of Hearn's Two Years in the French West Indies, Confiant makes three claims about Hearn. First, 'though largely ignored by historians of English and American literature, [he] is one of the most modern writers of the second half of the nineteenth century'. Secondly, he 'displayed a visionary conception of personal identity' (which Confiant links to his 'unusually mixed parental origins'). And thirdly, he 'invented what today we might call "multiple identity" or "creoleness"' (Hearn, 2000 
[1890]: ix-xii). ${ }^{2}$ However hyperbolic this latter claim might seem, Confiant makes it with some authority as one of the three author-signatories of the vastly influential pamphlet Éloge de la Créolité (Bernabé, Chamoiseau and Confiant 1989). ${ }^{3}$

In the present chapter, Hearn's writing trajectory will be shown to outline the basis of the Creole cultural continuum and to suggest the manner in which that continuum might cancel the boundaries between different geographical spaces, states, nations, cultures, genres and languages. Hearn's work will also be shown, however, to undermine what we might be tempted to regard as the limits of the Creole continuum itself: in other words what we might want to see as separating the Creole continuum from what lies beyond or outside it. To begin with, however, the questions studied here relate not to this latter, expanded heuristic paradigm of 'Creoleness', but more specifically to Hearn's interest in the parameters of the Creole world per se. When did Hearn first feel drawn towards these parameters? Which latent tensions or dynamics within his own background or constitution might have programmed this fascination with Louisiana and the Caribbean, leading him to devote more than twelve years of his life to these pre-eminently Creole locations? Which parts of his literary odyssey can be identified as Creole? Are the Ohio writings, which preceded his Creole sojourns, and perhaps even the Japanese work, which succeeded them, in some way related to his Creole gravitation?

More than most other labels of cultural identity, the term 'Creole' opens up highly complex questions of (inter-)cultural identity, difference and relation (see Stewart, 2007). 'Creoleness' is primarily the cultural consequence of the colonial expansion of Europe in the so-called 'New World'. Hearn's New Orleans writings explicitly address from early on the problematic semantics of the term 'Creole'. In an article entitled 'Los criollos', he writes about the plurality of definitions offered for the expression, most of them place-sensitive and many more race-sensitive. ${ }^{4}$ Hearn's article is impressively well informed and lucid for its time and shows that he was well aware of the complexity and ambiguities of the trans-linguistic and inter-linguistic connotations of this most slippery of signifiers, even if some of these connotations were constants: linguistic associations with the creolization of French and Spanish especially; associations with particular places (the American South, but also South and

2 Confiant's Foreword (p. xii) is entitled 'Lafcadio Hearn: The Magnificent Traveler'.

3 Gallimard subsequently published a bilingual (French/English) edition.

4 'Los criollos' appeared in 1877 in the Cincinnati Commercial just months after Hearn's arrival in New Orleans. 
Central America and the Caribbean); and, of course, most fundamentally an association with the moral and political catastrophe of slavery and with the racial and cultural combinations and relations founded on the coercive colonial history of transportation and exploitation. Hearn's article emphasizes in particular what he represents as the correct understanding of the term as deployed in Louisiana to refer exclusively to the descendants of the white French and Spanish aristocracy of the old South, now in decline. However, as his writings on and from the Caribbean clearly show, Hearn would himself use the term 'Creole' in a much less exclusive sense. ${ }^{5}$ It is no accident that the title of Hearn's article is in Spanish rather than English, for he was well aware of the fact that creolization was linguistically and culturally, if not ethnically or racially, a phenomenon pre-eminently associated with Latin, Mediterranean or Southern cultures. Indeed, as we shall see further on, in Hearn's explicit view the more Southern cultures blended or mixed much more intensively and successfully than did the more Northern English population, language and culture. However, as Hearn's mastery of Spanish was minimal in comparison with his knowledge of French, he naturally tended to dwell more on the French-Creole than on the Spanish-Creole world. Indeed, Hearn's francophilia seems to have been a key factor in his Creole tropism. Not only does his own work suggest that he had a keen interest in French (some of his most specifically literary labours were in the area of literary translation from the French), ${ }^{6}$ but his paternal uncle, Richard Hearn, had painted with the Barbizon School in France and Hearn later claimed that he himself had been educated for a time in France. Some of his biographers have decided that he spent a year at school in Yvetot (where Guy de Maupassant was also a pupil) although there is no evidence to substantiate that claim nor has any proof been adduced to the effect that he ever spent any significant period of time in France at all. ${ }^{7}$

If one of the major fixations of Hearn's entire 'American Period' was on the racial, cultural and aesthetic legacy of the New World plantation, he

5 Hearn's use of the term 'Creole' is not systematic. It is sometimes capitalized, but usually not, even when it refers to the Creole language, and is certainly not used exclusively in the narrow sense which is presented in 'Los criollos' as its most authentic meaning. See, for example, in 'Martinique Sketches', the reference to the 'creole negress or mulattress' (Hearn, 2009: 446).

6 Although many of his translations from the French appeared in periodicals, Hearn also published book-length translations of stories by Gautier, France and Maupassant, the first being the Gautier translation. See Works Cited for details.

7 For the most recently published overview of Hearn's French connection, see Lemoine, 2006. 
was particularly obsessed, then, with the Francophone and Hispanophone contexts, which gave rise to much more intense mixing or métissage. The general post-plantation obsession pre-dated, however, his move to New Orleans or to the Caribbean and, in this sense, Ohio seems to have offered him a proto-Creole experience.

If creolization was a direct consequence of colonial displacement and transportation, Hearn's affinities with Creoleness can be attributed in part at least to the texture of his own colonial and peripatetic origins and to his mixed descent and inheritance. Having been born in 1850 on the island of Levkas to a Greek mother and an Anglo-Irish surgeon in the British army, stationed in the Ionian Isles, Hearn's early childhood was marked by a radical and serial experience of dislocation and discontinuity. He was transplanted at the age of about three from his native Greece to Ireland and abandoned there by both his mother and father. He had little or no further contact with his father, who moved to India and started a second family, nor with his mother, who moved back to Greece and did likewise. To these factors of dislocation and dispossession as an orphan raised in Dublin by a widowed and childless great-aunt, must be added his education at boarding school in Durham, whence he drifted in his later teens to London and thence to New York.

\section{Hearn's Literary Trajectory in America}

Following the unsettled upbringing outlined above, Hearn emigrated to the United States in 1869 at the age of nineteen. He made his way to Cincinnati, home to a family contact of his Dublin grand-aunt and guardian, where he found work in the printing and publishing industry. He was hired in late 1872 as a reporter on the Cincinnati Enquirer. Hearn's copy for the Enquirer was not notably 'literary' or 'aesthetic' in orientation. It consisted indeed almost exclusively in prosaic reporting, although his literary inclinations surfaced in some of his more sensational or lurid articles. Most significantly, however, Hearn's work from this period suggests that he was drawn especially by the socially or ethnically marginalized and displaced. He thus reported not only on the dockland proletariat and on its squalid rim of prostitutes and criminals, but in particular on the 'black' ghettos around the levees, inhabited primarily, according to him, by the displaced ex-slaves of Kentucky and by other diasporic and minority communities - Irish, Italian and Jewish, for example. It was not simply the exotic aura of otherness surrounding the marginalized, the outlaw or the outcast that attracted him, but also the exoticism of racial difference and mixture and the dynamic of post-slavery (im)migration. The headlines of his Ohio journalism give a sense of the 
strength of this fascination, ${ }^{8}$ as does the fact that he married Mattie Foley, a black ex-slave with Irish connections. The marriage was short-lived, however, and, perhaps partly because of the cloud caused by his flouting of the colour code, Hearn ultimately left Cincinnati for the Deep South, and New Orleans. However, although the Cincinnati Enquirer dismissed him, perhaps for reasons related to his 'illegal' mixed-race marriage, a rival newspaper, the Cincinnati Commercial hired him and it was while he was still employed by the Commercial that he moved to New Orleans via Memphis. While he filed a significant amount of copy for the Cincinnati Commercial, it was more travel writing than reporting as such, and eventually, after that newspaper hired a different Louisiana correspondent, Hearn began to work for the New Orleans Item. Subsequently, however, he was appointed as Literary Editor of the New Orleans Times-Democrat, a position that gave him an opportunity to spread his literary wings. Nonetheless, most of the work that he published during his time both in Ohio and in Louisiana, not just in the local press but also in national periodicals such as Harpers, The Cosmopolitan, The Atlantic Monthly etc., and most of his American book-length publications also can best be regarded as amateur ethnography (avant la lettre). Even the titles of his articles and volumes convey this crypto-ethnographic perspective, a perspective that both enacts and highlights inter-cultural and inter-ethnic contact. Hearn's proto-ethnographic work in New Orleans includes, then, in addition to the prolific output of (journalistic) sketches, a Creole cookery book and a book of Creole proverbs (giving transcriptions of the Creole original along with their English translation), and it also includes the first of the two novellas that constitute his only attempts at literary fiction, a short narrative entitled Chita. The more elevated cultural tenor of Hearn's New Orleans writing emerges clearly from even a cursory comparison of the titles of his Ohio sketches with those of the New Orleans portraits: in Louisiana he no longer frequents the underworld of prisons, drinking dens, dumps or slaughterhouses in search of copy. ${ }^{9}$

It was only a small ethnological step from the Franco-Creole world of New Orleans to the pre-eminently Creole world of the Caribbean. In the summer of 1887, Hearn embarked from New York on a Caribbean cruise,

8 For example, 'Within the Bars. How Prisoners Look, Live, and Conduct Themselves: Some Glimpses of Life in the County Jail'; 'Some Pictures of Poverty: Impressions of a Round with an Overseer of the Poor'; 'Haceldama: Hebrew Slaughterers, Gentile Butchers, and Consumptive Blood-Drinkers'.

9 As examples of the New Orleans titles we could cite 'The French Market', 'Les Coulisses: The French Opera'; 'Old-Fashioned Houses'; 'New Orleans in Wet Weather'. 
armed with a commission from Harper's Magazine. His account of the trip, entitled A Midsummer Trip to the Tropics, appeared in that publication in 1888. A short time after his return from the Caribbean journey, Hearn went back to Martinique where he would spend almost two years. He wrote up this experience as a series of portraits of life on the tiny French Caribbean island, and went on to publish them in 1890 under the title Martinique Sketches along with the relatively brief account of the inaugural Midsummer trip, in a single tome entitled Two Years in the French West Indies. Most of these sketches have French titles: 'Les Porteuses, 'La Guiablesse', 'La Vérette', 'Un Revenant', although some have titles in Creole ('Pa Combiné, Chè'). Some contain transcriptions/translations of Creole songs and stories, and all document the local way of life and local expression and belief. Although some of these pieces were published in Harper's Magazine while Hearn was still in Martinique, he also brought back to the United States material that he had collected and drafted in Martinique, including the material for his second novella, Youma, a story of the role of slavery in Martinican plantation slavery and also his transcriptions of Creole folktales (Hearn, 1939; 2002: published posthumously in the Creole version with a French translation by the editors of the two volumes concerned). ${ }^{10}$

\section{An Ethnographic Poetics}

\section{The Ethnographic Continuum of Hearn's American Writings}

As the brief bibliographical summary above indicates, the American period of Hearn's writing career encompasses both literature and journalism, both prose fiction and travel writing, both transcriptions of folklore and literary translation. However, even if a clear generic distinction can be made between fiction, travel writing and journalistic sketches, what unites Hearn's practice of all three genres is both an ethnographic focus and the object of that focus. The continuity of Hearn's American writings from Ohio to Martinique is based on his documentation of the ethos and aesthetic of the folk culture that emerged from plantation slavery.

Hearn's American writings include three particularly striking travel accounts. The first recounts his journey South to New Orleans from Ohio via Memphis; the second records his journey to and within the Caribbean ('A Midsummer Trip to the Tropics'); and the third his 'A Winter Journey to Japan'.11 In this sense, his work bears out Mary Louise Pratt's assertion

10 For a study of the importance of folk narratives in Hearn's work, see Gallagher, 2010 .

11 'Memphis to New Orleans', Cincinnati Commercial, 23 November 1877; 'A 
that 'by the late nineteenth century [...] two [writing] modes [narrative and description] often had about equal weight in travel books, and [that] it was common for a trip to result in two separate volumes' (Pratt 1986: 35). The fact that the travel accounts were followed in all three cases by an extraordinarily prolific series of sketches of the way of life of the traveller-become-ethnographer confirms Pratt's observation that 'the authority of the ethnographer over the "mere traveller" rests chiefly on the idea that the traveller just passes through, whereas the ethnographer lives with the group under study' (ibid.: 38). Hearn's use of informants in New Orleans and in Martinique and his emphasis on the importance of cultivating them (and more generally of living with and among the people whose culture he is studying); his emphasis too, especially in Martinique, on the latter's non-literacy, underlines the modelling of Hearn's writing on the anthropological paradigm of observerparticipation. Similarly, his rehearsal of other conventions of traditional anthropology/ethnography such as a transitive authorial perspective on the objectified culture, the latter's construction as 'other' (often as 'primitive' or 'underveloped'), the utopian undertones of that construction and the anticipated nostalgia in the future anterior tense, further confirm the resonance of the traditional anthropological/ethnological paradigm in Hearn's writing. The primacy of Hearn's ethnographic focus is indeed confirmed by Simon Bronner's edition of selected texts by Hearn belonging to his Ohio and New Orleans periods: a volume entitled Lafcadio Hearn's America and subtitled Ethnographic Sketches and Editorials. As Bronner recognises, the ethnographic specificity of Hearn's writing relates in great part to his object: the underside of contemporary urban life in America. Hearn's ethnological object is in line with the ethnological paradigm of his day in that its predominant orality and its marginality could only be constructed as other in relation to the dominant, analysing culture. Yet that object was out of line with the ethnological paradigm of the day in that it was in many respects coeval (economically integrated into its industrial context) and geographically 'to hand', and above all in that it was in no sense 'other' or 'primitive' in the sense of 'pure' or 'untouched', but was rather thoroughly mixed or 'contaminated' by contact with the culture viewed as 'standard'. Although there is no indication of any real identification on Hearn's part with his 'ethnographic' object in Ohio, his writing on New Orleans and on Martinique certainly suggests an affinity or a fascination bespeaking transient desire and even, perhaps, moments of transference. However, although in some of his New Orleans correspondence Hearn signs himself the recipient's 'creolised

Midsummer Trip to the Tropics', Harper's Magazine, July, August and September 1888; 'A Winter Journey to Japan', Harper's Magazine, November 1890. 
friend', ${ }^{12}$ he rarely ever blurs the insider/outsider distinction. His is a position not just of exteriority but also of assumed superiority. This is expressed less, however, as a racial or political superiority, than as the cultural superiority of the ethnographer qua writer and of the latter's penetrative, encompassing, comparative and aesthetic intelligence.

\section{The Continuity of Hearn's Ethnographic Object}

The 'otherness' of the object of Hearn's ethnographic attention is especially over-determined in the French-Creole context. The groups that he describes in Cincinnati, although they belong to a socially subordinate stratum and are often confined to the racial and cultural ghettos inhabited by ex-slaves, are mostly English-speaking, even if Hearn is at pains to document the local peculiarities of the English dialect that they speak. It is, moreover, the presence of the Irish overlay in that 'ex-slave' dialect that interests Hearn rather than the intrinsic aesthetic quality of the language. In contrast, the culture and language of the inhabitants of New Orleans and Martinique, although they similarly are from the collapsed American plantation culture, are constructed by Hearn as uniquely attractive and refined. For him, the two key attractions of the Creole culture of Louisiana and the Caribbean are its aesthetic grace, based on a higher degree of mixture or blending than in the Anglophone contexts of the Ohio ghettos or the Kentucky plantations, and the inherent qualities of the old French- or Spanish-influenced colonial worlds in which that culture was formed. Two further factors distinguish Hearn's ethnographic perspective on the post-plantation world of New Orleans and Martinique from his focus on the post-plantation population of the Cincinnati ghettos: first, the latter's greater temporal proximity to, and greater spatial distance from, slavery: the ex-slaves of the Cincinnati levees had moved to Ohio directly from slavery on the plantations of Kentucky and other more 'deeply' Southern states; secondly, the role opened up for the imagination. Hearn is particularly inclined to flights of fancy that convert the real New Orleans or Martinican scene to an imagined, remembered, or dreamed one. Because his writing on the Franco-Creole world constantly veers from description to imagination, his processing of his impressions of that world is not restricted as it is in Ohio to factual reportage. Instead, both in New Orleans and in Martinique, Hearn attempts not only to document a given culture, but also to unearth its latent references by comparing it, for example, to the worlds of Ancient Greece and Rome and to use it as inspiration for literary creativity. In fact, Hearn's only two forays into literary

12 This is how Hearn signs a letter that he wrote to Krehbiel from New Orleans in 1883 (Bisland, 1906: 280). 
fiction were based on his research into life on Grande Isle and into the specifics of Caribbean slavery.

Hearn sees this work as providing, above all, a record of post-plantation American folk culture, especially language and oral production. Despite the gulf between the Ohio levee, the French Quarter of New Orleans and the island of Martinique, his descriptions of his collection and transcription of oral culture in all three locations are, in several respects, strikingly analogous. In Cincinnati he dwells in particular on the English dialect of levee culture. Thus, in 'Levee Life: Haunts and Pastimes of the Roustabouts', he phonetically transcribes the lyrics of the songs sung by one Jim Delaney: 'One fact worth mentioning about these negro singers is that they can mimic the Irish accent to [...] perfection' (Hearn, in Bronner, 2002: 45). Similarly, shortly after arriving in New Orleans he writes to his musicologist friend Henry Krehbiel of a 'black nurse' who sings a 'voodoo song', which she herself does not understand. 'I tried to write down the words, but as I did not know what they meant I had to write by sound alone, spelling the words according to the French pronunciation' (Hearn, 2009: 780). ${ }^{13}$ His ambition in New Orleans is, therefore, just as it had also been in Ohio, to document the local language and to collect local folklore: He adumbrates 'a project which I hardly hope to succeed in, but which I feel some zeal regarding [...]: to collect the Creole legends, traditions, and songs of Louisiana' (Hearn, 2009: 780). In another letter from New Orleans, dated 1881, he again mentions this project to Krehbiel: 'I should like one day to talk with you about the possibility of contributing a romantic [...] series of little sketches upon the creole songs and colored creoles of New Orleans, to some New York periodical' (ibid.: 790).

Hearn's perspective is strikingly similar in Martinique. In his 'Martinique Sketches' (1890) he frequently refers to his efforts to live close to his sources. Thus, at the beginning of 'La Vérette', he writes of his good fortune in finding accommodation in Saint-Pierre, noting that 'the poorer the neighbourhood, the better one's chance to see something of its human nature' (Hearn, 2009: 339). In another sketch, entitled 'Yé' (1890), he writes of having 'succeeded in getting [stories] dictated' - stories that he heard children telling to each other in the street 'every night, just before bedtime' (Hearn, 2009: 514).

The continuity of Hearn's ethnographic project in all three locations is clear. What is also clear, however, from his correspondence and from his publication of the two novellas Chita (researched from New Orleans) and Youma (researched in Martinique) is that he harboured in addition more creative literary ambitions, which he was tempted originally to see as an

13 This letter to Krehbiel is dated 1878, just one year after Hearn arrived in New Orleans. 
escape from, or as a more amenable alternative to, the rigours and costs of research. As early as 1881, he had written to Krehbiel from New Orleans, 'I could not write one little story of antique life really worthy of the subject without such hard study as I am no longer able to undertake and a purchase of many costly works above my means. The world of Imagination is alone left open to me. It allows of a vagueness of expression which hides the absence of real knowledge, and dispenses with the necessity of technical precision of detail' (Hearn, 2009: 792).

\section{An Aesthetics of Physical and Linguistic 'Métissage'}

Although each set of writings is written in a slightly different key, with a clear modulation of tone and language from one to the next, the object of Hearn's 'ethnographic writings' shows a certain constancy from Ohio to New Orleans to Martinique. This is not simply because of a common focus on 'port cultures' of the Atlantic World. It is also because of a deeply rooted fascination with America's colonial past, specifically the world of the plantation as dominated by slavery and by racial hierarchy, and an equally clear obsession with the legacy of that past, more specifically with an aesthetics of métissage and with the specificity of the oral, folk culture yielded by that world (especially language, music, songs, stories, dance etc.). Hearn was particularly transfixed by the depth of the inter-ethnic and interlinguistic palimpsest that distinguished post-plantation culture. Three Ohio texts clearly illustrate this double preoccupation with métissage and with cultural specificity. The first is entitled 'Pariah People: Outcast Life by Night in the East End. The Underground Dens of Bucktown and the People Who Live in 'Them' and it clearly underlines Hearn's aesthetic sensitivities. His references both to slave culture and to an aesthetics of miscegenation are clear in the following description:

negresses, stronger than men, whose immense stature and phenomenal muscularity bear strong witness to the old slave custom of human stock breeding; neatly built mulatto girls, with the supple, pantherish strength peculiar to half-breeds; slender octoroons, willowy and graceful of figure, with a good claim to the qualification pretty, - will all be found among the crowd of cotton-turbaned and ebon-visaged throng, who talk alike and think alike and all live and look alike. (Bronner, 2002: 89) ${ }^{14}$

14 'Pariah People' was published in the Cincinnati Commercial on 22 August 1875. It is reprinted in Bronner, 2002. Italics are mine in this and all subsequent quotations, unless otherwise indicated. 
The focus on the bounded specificity of ex-slave culture is much sharper in the following quotation, taken from 'Levee Life'. Hearn is at pains to point out the 'intense uniqueness' of this particular way of life, its 'peculiarities', which are of a 'strictly local quality'. What he wants to stress is its quiddity: 'its boundaries are most definitely fixed':

Roustabout life in the truest sense is, then, the life of the colored population of the Rows, and partly, of Bucktown - blacks and mulattoes from all parts of the States, but chiefly from Kentucky and Eastern Virginia, where most of them appear to have toiled on the plantations before Freedom; and echoes of the old plantation life still live in their songs and their pastimes. You may hear old Kentucky slave songs chanted nightly on the steamboasts, in that wild, half-melancholy key peculiar to the natural music of the African race, and you may see the old slave dances nightly performed to the air of some ancient Virginia-reel in the dance-houses of Sausage Row, or the 'ball-rooms' of Bucktown. There is an intense uniqueness about all this pariah existence, its boundaries are most definitely fixed; its enjoyments are wholly sensual, and many of them are marked by peculiarities of a strictly local character. Many of their songs which have never appeared in print, treat of levee life in Cincinnati of all the popular steamboats running on the 'Muddy Water'. (Bronner, 2002: 38)15

In the third sketch, 'Black Varieties', Hearn particularly admires the ethnic diversity, the racial and cultural variation of the population: 'Every conceivable hue possible to the human skin might be studied in the dense and motley throng that filled the hall' (Bronner, 2002: 171) ${ }^{16}$ He does highlight also, however, the pleasing 'Southern' style of the women's dress and appearances: 'There were full-blooded black women, solidly built [wearing] handkerchiefs of divers colors twined about their curly pates, after the old Southern fashion' (Bronner, 2002: 171). Not only are aesthetic concerns at the heart of Hearn's writing on the Bucktown ghettos, but even if the population and its way of life are unique, they do recall an 'other' time, acting as ghostly reminders of plantation slavery.

Although exactly the same interests and values recur in Hearn's New Orleans and Caribbean writings, they are expressed there in different terms. The population and the culture of New Orleans are represented as being considerably more elevated or refined than those of Cincinnati. The

15 From 'Levee Life: Haunts and Pastimes of the Roustabouts', an article first published in the Cincinnati Commercial, 17 March 1876.

16 From 'Black Varieties: The Minstrels of the Row - Picturesque Scenes Without Scenery', first published in the Cincinnati Commercial, 9 April 1876. 
animalistic comparisons disappear, and although the inhabitants of the city are still racially labelled and objectified, the descriptions are expressed in less (to later ears, repugnantly) zoological and pseudo-scientific terms; the latter register is replaced by a more 'artistic' or 'aesthetic' one. The tone of gothic grotesque gives way to pervasive allusion to ancient Greek and Rome. It is the 'French quarter' and the French and Spanish aesthetic influences that are singled out for particular aesthetic admiration in New Orleans, while, in the Caribbean writings, the Creole-speaking islands, particularly those with surviving French or Spanish Creole cultures, are singled out for praise denied to the language and culture of the English-speaking islands such as Barbados, whose atmosphere Hearn regards as inherently less mixed, less various and (consequently) less aesthetic than that of the French- or SpanishCreole-speaking islands. Of the Barbadian population, Hearn writes that as a mass, [it] strikes one as the darkest of the West Indies [...] by no means an attractive population, physically, - rather the reverse and frankly brutal as well - different as possible from the colored race of Martinique'. Hearn also comments on the 'purity of Barbadian English' and on the fact that 'the commonest negro laborer about the port pronounces as well as a Londoner' (Hearn, 2009: 213-14).

Hearn's literary and linguistic francophilia has already been noted in relation to his translation work. However, it also emerges in his reporting on the Cincinnati ghettos: thus, in 'Pariah People', Eugène Sue's Les Mystères de Paris is the comparator for the 'hideous haunts' (Bronner, 2002: 90) of Bucktown. This French orientation extends even to the journalism based on the poorest of the poor in Cincinatti, the scavengers on the dumps, since he gives a French title, 'Les Chiffonniers', to his article and compares their way of life to the art of Gustave Doré: 'a fantastically dismal and darksome poetry' (Bronner, 2002: 97). ${ }^{17}$ However, not even these French comparators can elevate the sights and sounds of Bucktown as high as the pedestal on which Hearn puts the French- and Spanish-influenced cultural aesthetic of parts of New Orleans and of the Caribbean. Apart entirely, however, from his praise of the inherent musicality of French and French Creole, Hearn's New Orleans and Caribbean writings themselves become more and more marked by the presence of French words and expressions. Several explicit comments on French, English and Creole, as spoken in New Orleans and the Caribbean, are most revealing in this respect. In 'The City of the South', one of the first pieces that he wrote in New Orleans, he notes that 'a large proportion of the

17 'Les Chiffonniers: Rags, Wretchedness and Rascality. The Gnomes of the Dumps, How they Live, Work, and Have their Being' was published in the Cincinnati Enquirer, 26 July 1874. 
lodging houses here are kept by colored women. Especially is this the case in the French Quarter. All these colored concierges speak both French and English. Their English, often deficient, is invested with the oddest French accent imaginable. ${ }^{18}$ He goes on to claim, however, that the 'French language sounds to me far more natural than our own in a black mouth, [because it is] beyond the power of Ethiopian lips to master [...] rugged sounds [and because] French is barren of rugged sounds' (Starr, 2001: 15).

Revealing that he had already been attracted to the Creole language before he had ever set foot in America, he outlines his view of Caribbean Creole as constituting the nec plus ultra of New World dialects.

Yesterday evening, the first time for ten years, I heard again that sweetest of all dialects, the Creole of the Antilles. I had first heard it spoken in England by the children of an English family from Trinidad, who were visiting relatives in the mother country and I could never forget its melody. In Martinique and elsewhere it has almost become a written dialect; the schoolchildren used to study the Creole catechism and priests used to preach to their congregations in Creole. (Starr, 2001: 16)

Caribbean Creole is characterized as intrinsically 'poetic and musical': 'the most liquid, mellow, languid language in the world, especially a language for love-making' (Starr, 2001: 16). To his ears it 'sounds like pretty baby talk' and 'seems to be a mixture of French, a little Spanish and West African dialects' (ibid.). In contrast, '[t]he patois of Louisiana is not nearly so soft [and is] simply corrupted French' (ibid.).

We have already noted that the ex-slave songsters of the levee use an English overlaid with an Irish accent and with pronunciation patterns specific to people of African descent. However, the levee language that Hearn transcribes is almost standard English with only slight variations in phonetic transcription registering what is represented as an Irish accent being mimicked by the singers. If this Levee dialect is regarded less favourably than the Louisiana patois which is denigrated in turn in relation to Caribbean Creole, this is because of the greater degree of métissage, blending or palimpsest at work and also because of the mellifluous musicality French in comparison to the more abrasive sounds of English.

18 'The City of the South' was first published in the Cincinnati Commercial on 10 December 1877. It is reprinted in Starr, 2001: 15. 


\section{Into the Creole Core: Towards an Aesthetic Apotheosis}

In his text 'Memphis to New Orleans', dated 14 November 1877, Hearn writes extensively about the faded, dilapidated splendour of the plantations, which he imagines as they used to be in the old slave days. He dwells on the signs of sad ruin on the face of the great plantations, [...] splendid houses crumbling to decay, and whole towns of tenantless cabins; estates of immense extent were lying almost untilled [...] reflection of a glory passed away, the glory of wealth [...] o fair paradise of the South' (Starr, 2001: 5).

In another 'arrival scene' article entitled 'At the Gate of the Tropics', dated 19 November 1877, Hearn describes New Orleans as being pre-eminently a port city, evoking the river traffic and the levee atmosphere complete with 'swarthy stevedores' (Starr, 2001: 7), these features all recalling his dominant impressions of Cincinnati. Further underlining a sense of continuum between Hearn's chosen American locations, he mentions specifically too the 'shapely craft from West Indian harbours' that grace the New Orleans docklands and notes that the city recalls all 'seaports in the tropics' (ibid.). He observes, however, that New Orleans 'actually resembles no other city upon the face of the earth, yet it recalls vague memories of a hundred cities' (ibid.). Similarly, he considers that the 'fascination which New Orleans exercises upon foreigners is due no less to this peculiar characteristic than to the tropical beauty of the city itself' (ibid.). The city instantly appeals to Hearn, then, because of its tropicality and its faded, dying Southern splendour. But it also appeals because of its transcendence of singularity, its transcendence of its limits. The immense diversity that it suggests renders the city impossible to capture within a single definition, and this diversity stimulates the imagination. 'If this be not the cosmopolitan city of the world, it is certainly the cosmopolitan city of the Americas', Hearn writes, explaining that 'Whensoever the traveller may have come, he may find in the Crescent City some memory of his home - some recollection of his Fatherland - some remembrance of something he loves' (ibid.). Hearn's instant approval of New Orleans seems to be based, then, on its embodiment of two key values: displacement and continuum. This 'port city' is not just a place of arrival and departure, a site of multiple migration, but also a space of multiple memories, echoes and references, which it has registered in a richly textured, memorial palimpsest.

The analogies between the Louisiana and the Caribbean arrival scenes are quite clear from a comparative reading of Hearn's account of his inaugural trip to the Caribbean. Thus, when viewed from the bay, under the green shadow of the hills overlooking it, Frederiksted (in Santa Cruz, the first Caribbean island sighted by Hearn) appears to be, like the post-plantation world of Louisiana, both beautiful and in ruins. It 
has the appearance of a beautiful Spanish town, with its Romanesque piazzas, churches, many arched buildings peeping through breaks in a line of mahogany, bread-fruit, mango, tamarind, and palm trees, - an irregular mass of at least fifty different tints, from a fiery emerald to a sombre bluishgreen. But on entering the streets the illusion of beauty passes: you find yourself in a crumbling, decaying town, with buildings only two stories high. [...] all the buildings look dilapidated; the stucco and paint is falling or peeling everywhere; there are fissures in the walls, crumbling façades, tumbling roofs. (Hearn, 2009: 168) ${ }^{19}$

An implicit reference to slavery, present in the reference to the reconstruction necessitated by a 'negro revolt in 1878', highlights the architectural inscription of time and racial interrelation. Similarly, the language spoken in Santa Cruz, although it reminds Hearn of the English of New Orleans while lacking the aesthetic leaven provided in Louisiana by the influence of French, is nonetheless a 'mixed' language, 'a negro-English that sounds like some African tongue' (Hearn, 2009: 168). This 'English jargon' does not appeal to Hearn, however, nor does he find much to recommend in the costumes of the island's womenfolk, who are 'very simply, almost savagely garbed' (ibid.: 169). However, as his trip takes him on to the more 'French' or 'Spanish' atmospheres of St Kitts, Montserrat, Dominica and Martinique, the resonances of the New Orleans descriptions become much more apparent and the city is indeed referenced in the description of his first impressions of St Pierre:

We are ashore in St. Pierre, the quaintest, queerest, and the prettiest withal, amongst West Indian cities: all stone-built and stone-flagged, with very narrow streets, wooden or zinc awnings, and peaked roofs of red tile, pierced by gabled dormers. [...] The architecture is quite old; it is seventeenth century, probably; and it reminds one a great deal of that characterizing the antiquated French quarter of New Orleans. All the tints, the forms, the vistas, would seem to have been especially selected or designed for aquarelle studies, - just to please the whim of some extravagant artist. (Hearn, 2009: 177)

Hearn proclaims that '[p]icturesqueness and color [are] the particular and the unrivalled charms of St. Pierre' (Hearn 2009, 180). Moreover, in a perhaps not gratuitous description, he identifies the 'characteristic odor of St. Pierre' as 'a compound odor suggesting the intermingling of sugar and garlic in those

19 The 'Midsummer Trip to the Tropics' appears along with many other important texts and letters in Hearn, 2009: 159-246. 
strange tropical dishes which creoles love' (ibid.). As for the population of St Pierre, the town boasts the 'finest mixed race of the West Indies', distinguished by 'dignified carriage and easy elegance of movement' (ibid.: 181). It is deemed 'fantastic, astonishing, - a population of the Arabian Nights. [...] many-colored [...] yellow in the interblending of all the hues characterizing mulâtresse, capresse, griffe, quarteronne, métisse, chabine, - a general effect of rich brownish yellow' (ibid.). Variation and diversity are clearly prized values here, but so too is mixture or 'interblending'. Like the population of New Orleans, deemed 'so mixed up that no human being can tell what nation anybody belongs to' (ibid.: 783), the combinatory richness of the 'mixed races' of the Caribbean appeals to Hearn's intelligence. Furthermore, the supremely blended Martinicans all appear inherently appealing: 'vigorous, graceful, healthy' (ibid.: 189), they remind him of bronze sculptures. He notes that 'all clear tones of bronze [are] represented' (ibid.: 188) and that the people 'have the aspect of sculptural models' (ibid.: 189).

Three themes predominate in Hearn's encomium to the Creole aesthetic of Martinique. First, the aesthetic sense of a compound, richly various perfection; secondly, the temporal or historical depth to which these combinations and mixtures bear witness; and finally, the 'sense of an ending'. In relation to this last point, the fact that the Creole aesthetic of Martinique suggests 'the earliest civilizations ${ }^{20}$ underlines the general sense of decline and ruin that predominates in Hearn's first impressions of the Caribbean (and also, indeed, of New Orleans) and that culminates in his prediction that the mixed races of the Caribbean are doomed to extinction. ${ }^{21}$

\section{The Temporal Depth of Palimpsest: Hearn's Creolophilia as Antiquarianism}

When Hearn claims that there is 'much to gratify an artist's eye in this quaint curious crooked French Quarter' (Starr, 2001: 7) of New Orleans, he is thinking less of its dilapidation than of its suggestiveness of the past. This suggestiveness is expressed both in terms of its evocation of the Ancient World and in terms of its reference to the recent colonial history of the

20 In Grenada, for example, what struck him most was the 'dilapidation of her capital and the seeming desolation of its environs' caused by the 'decay of the sugar industry'. From 'Les Blanchisseuses' in 'Martinique Sketches' (Hearn, 2009: 374).

21 At the end of 'A Midsummer Trip to the Tropics', he writes: 'All these mixed races, all these beautiful fruit-coloured populations, seem doomed to extinction: the future tendency must be to universal blackness' (Hearn, 2009: 246). 
New World. The 'French Quarter' of the city thus suggests to Hearn 'many memories of old France', the France to which the first settlers belonged, even if it also evokes the ruin and decay of the domains of the last 'Great Planters of the South' (ibid.: 8). He dwells upon the very faded glory of the city's 'Great hotels', for example the St Charles, with its 'vast Corinthian columns', 'antique lines of beauty' and 'noble Greek façades' (ibid.). For Hearn, the city's 'elegant, gracious architecture appears adapted to this sky and this sunny clime', and he imagines that 'it was under almost such a sky and such a sun that the Greek architecture was born' (ibid.). Hearn's own Mediterranean origins may well be related to his descriptions of the Creole world that reference classical Greece, but one of the clear effects of this reference is to underline the sense of Creole culture as a 'civilization' in its own right, a civilization that could stand comparison with Ancient Greece and Rome, and, most crucially of all, as a civilization currently in fin-de-siècle decline.

The 'antiquarian' dimension of Hearn's attraction to the Creole world, including the 'antiquated dialect of the French Quarter' (Hearn, 2009: 777) of New Orleans, is primarily illustrated in the Martinican writings by comments on the Creole body as recalling Classical sculptural art and in all Hearn's Creole writings by his comparison of Creole and Ancient Greek architecture. In a more general sense, however, Creoleness per se is temporal and interrelational depth made visible, and in this sense the broad pan-colonial aesthetic that so fascinates Hearn finds its apotheosis in the Creole world of Martinique. In Louisiana also, however, and even outside the French Creole context altogether, in Ohio, the post-plantation aesthetic demonstrates historical interface by conserving and superimposing audible and visible combinations (for example, the Irish-accented dialect of the Ohio ex-slaves).

The greater the intrinsic aesthetic grace of the elements combined and conserved in postcolonial compounds, the greater the number of different combinations and the greater the extent of the combination or mixture, the more intellectual and aesthetic pleasure Hearn declares. This equation explains the particular charm for him of historical superimpositions of different colonial presences, such as the successive combinations allowed by the replacement of the Spanish colonial presence by the French settlement in New Orleans. Hearn's comments on the architecture of New Orleans make the appeal of such colonial palimpsest very clear. Thus, 'The City of the South' mentions 'The old Spanish cathedral' and notes that Hearn was initially 'terribly disappointed about it' (Starr, 2001: 13). After having crumbled, 'it was reconstructed Frenchily, and has lost its Spanish features' (ibid.). He notes, however, that 'You may still find those features preserved in certain old prints that hang, yellow with age and spotted with fly-specks, 
in the offices of certain ancient Notaries of the French Quarter; and you will find that Don André built the cathedral after that curiously mixed, but not unimposing style that characterizes the old cathedrals of Spanish-America' and that it had, for example, 'towers with Roman-arched windows' (ibid.). He goes on to note that tombs in the French Cathedral include that of

the noble French family De Marigny de Mandeville, ante-revolutionary, aristocrats all, who may have strutted in those picturesque costumes we are familiar with in the paintings of the period; who belonged in the age in which gentlemen bowed and took snuff with an ineffable grace which this uncultivated generation are powerless to conceive of. (Starr, 2001: 14)

Hearn's admiration of the manners and style of the French Ancien Régime could not be clearer. His fascination with the architecture of New Orleans is thus based on the historical patina that registers (successively or simultaneously) both Spanish and French features, and on its conservation (in aspic, as it were) of the shared 'Old World' style of these features. 'New Orleans', he writes in a piece entitled 'The Streets', 'alone of American cities, has preserved all the romance of its earlier days in the titles of its streets, and with a simple directory one can recall the entire history of the French and Spanish dominion' (Starr, 2001: 18). Similarly, the palimpsest of the Creole patois as spoken in the Caribbean preserves the 'entire history' of the mutations and exchanges of the old colonial world. In his 'Midsummer Trip to the Tropics', he writes that

Now, in almost every island the negro idiom is different. So often have some of the Antilles changed owners, moreover, that in them the negro has never been able to form a true patois. He had scarcely acquired some idea of the language of his first masters, when other rulers and another tongue were thrust upon him, - and this may have occurred three or four times! (Hearn, 2009: 239)

\section{Conclusion}

The extent to which all of Hearn's work, including his Japanese writings, was underwritten by his fascination with Creole palimpsest is not a matter that can be explored in this study. The various factors that have been suggested here as explaining and sustaining that fascination (Hearn's own culturally diverse origins, his experience of cultural displacement and interrelation and his consequential interest in cultural transcription and translation) may indeed have found another outlet in his Japan writings. Certainly, almost every line of his American writings, stretching over twenty years, testifies 
to his fixation on the Creole continuum of ethnic, cultural and linguistic palimpsest which links the two post-plantation worlds of Louisiana and the Caribbean, a continuum that spills over, however, not just into the Anglophone and Hispanophone post-colonies of the Caribbean, but also into Cincinatti's mixed urban ghettos where Hearn first encountered it. Thus, when claiming for Hearn the status of honorary 'Creoleness' on the basis of his adoption of 'multiple identity', the founders of the 'Créolité' movement are saluting his espousal of a 'diversalité' which is less a function of the particular diverse elements brought into relation with each other in the Creole crucible than of the universal dynamic and aesthetic of contact and interaction produced by all cultural dislocation and relocation.

\section{Works Cited}

Bernabé, Jean, Patrick Chamoiseau, and Raphaël Confiant. 1989. Éloge de la Créolité. Paris: Gallimard.

Bisland, Elizabeth. 1906. The Life and Letters of Lafcadio Hearn. Boston, MA: Houghton Mifflin.

Bronner, Simon J. (ed.). 2002. Lafcadio Hearn's America: Ethnographic Sketches and Editorials. Lexington: University Press of Kentucky.

Chamoiseau, Patrick, and Raphaël Confiant. 1991. Lettres créoles: tracées antillaises et continentales de la littérature, 1635-1975. Paris: Hatier.

Gallagher, Mary. 2010. 'The Creole Folktale in the Writing of Lafcadio Hearn: An Aesthetic of Mediation'. In Janice Carruthers and Maeve McCusker (eds), Le Conte: Oral and Written Dynamics. Berne: Peter Lang: 133-51.

Hearn, Lafcadio (trans.). 1882. Théophile Gautier. One of Cleopatra's Nights and Other Fantastic Romances. New York: R. Worthington.

-. 1885a. La Cuisine Créole: A Collection of Culinary Recipes. New York: Will H. Coleman,

-. 1885b. Gombo Zhèbes: A Little Dictionary of Creole Proverbs. New York: Will H. Coleman.

-. 1889. Chita: A Memory of Last Island. New York: Harper \& Bros.

-. (trans.). 1890a. Anatole France, The Crime of Sylvestre Bonnard. New York: Harper \& Bros.

-. 1890b. Youma: The Story of a West-Indian Slave. New York, Harper \& Bros.

- 1939. Trois fois bel conte. Trans. by Serge Denis, with Preface by Charles-Marie Garnier. Paris: Mercure de France.

-. 2000 [1890]. Two Years in the French West Indies. Foreword by Raphaël Confiant. Oxford: Signal Books.

- 2002. Contes créoles II. Collected by Lafcadio Hearn, transcribed and translated by Louis Solo Martinel. Le Lamentin: Ibis rouge. 
-. 2009. American Writings. Edited by Christopher Benfey. New York: Library of America.

Lemoine, Bernadette. 2006. 'Lafcadio Hearn as an Ambassador of French Literature in the United States and in Japan'. Revue de littérature comparée. July-September: 299-317.

Pratt, Mary Louise. 1986. 'Fieldwork in Common Places'. In James Clifford and George E. Marcus (eds), Writing Culture: The Poetics and Politics of Ethnography. Berkeley: University of California Press.

Starr, Frederick (ed.). 2001. Inventing New Orleans: Writings by Lafcadio Hearn. Jackson: University Press of Mississippi,

Stewart, Charles (ed.). 2007. Creolization: History, Ethnography, Theory. Walnut Creek, CA: Left Coast Press. 


\title{
Auguste Lussan's La Famille créole: How Saint-Domingue Émigrés Became Louisiana Creoles
}

\author{
Typhaine Leservot
}

\section{Introduction}

The 1791 slave uprising in Saint-Domingue, followed by the revolution and Haiti's independence in 1804, had a profound impact on Louisiana. Soon after the uprising began, hundreds of refugees from the island trickled into New Orleans. Around 1803, thousands more arrived. Six years later, in a few months between 1809 and 1810, 10,000 of them poured into the region when they were no longer welcome in Cuba, where they had first settled after fleeing Saint-Domingue. The sheer number of refugees doubled the population of New Orleans, which reached 25,000 by 1810 , turning it into the seventh largest city in the United States; by 1820, it was the fifth largest. The Saint-Domingue refugees' impact on New Orleans in particular, and on Louisiana as a whole, was not just numerical. Within a few decades, they transformed the city into a cultural centre: the refugees created the first newspapers, theatres and opera in New Orleans. Economically, although most refugees were impoverished when they arrived in Louisiana, many became part of a successful middle class as merchants, teachers, journalists, actors, politicians, lawyers and doctors. Politically, they added to the controversies surrounding Louisiana's loyalty to the American government by boosting the number of French speakers, and they reinforced the three-tiered racial system that troubled Americans, who were accustomed to a binary racial organization.

By the late 1830s, at the time of Auguste Lussan's play La Famille créole [The Creole Family] (1837), Louisianians' collective memory of this important community was already beginning to fade as the death of older refugees and exogamy dissolved the community (although not its culture) within the larger 
Creole society of the region (Dessens, 2007: 61-62). Lussan's play acts as a reminder of the centrality of the Saint-Domingue refugees to Louisiana's identity by telling the story of the Clairville family, former planters from Saint-Domingue. But it does so in a way that carefully Americanizes both Louisiana and its Creole refugees. Typical of the genre of the melodrama to which it belongs, it offered entertainment with a conservative ideology that was reassuring for the public during chaotic times (Przybos, 1984: 308). ${ }^{1}$ The portrait of Creoles given by Lussan is indeed a reassuring one, one that avoids the predominant political controversy of Louisiana in the early nineteenth century, namely slavery, while highlighting the Creoles' loyalty to the young United States. Given the important political role theatre played in Louisiana at the time, it should perhaps not be surprising to discover that Lussan's 1837 melodrama could be more than entertainment.

Founded at the turn of the century thanks in large part to Saint-Domingue refugee actors, theatres were booming in Louisiana by the 1830s and 1840s. Part entertainment, Louisiana plays and theatres also participated in the identity politics of the region where French, Creole, Cajun and Spanish influences faced a rising Americanization after Louisiana became a state in 1812. According to Lewis William Newton, Louisiana theatres were one of the social factors that influenced race relations (Newton, 1929: 192-227) as well as relations between the Francophone and Anglophone communities in Louisiana (ibid.: 155-91). Lussan's La Famille créole, with its careful avoidance of the issue of slavery and its equally careful Americanization of the Clairville family, exemplifies this.

Little is know about Lussan himself. Born in France, where it is believed he was a struggling artist, he came to New Orleans in the 1830s to pursue his acting career, became a published poet and playwright, and died in 1842 . He is perhaps best remembered for his tragedy in verse Les Martyrs de la Louisiane (1839), a highly patriotic play that tells the story of the 1768 revolution in Louisiana during which Frenchmen defied the then Spanish governor and were killed. Alcée Fortier reveals that Les Martyrs was particularly successful and became well read by both French and American Louisianians for its patriotic dimension (Fortier, 1886: 39). Although less known than Les Martyrs, Lussan's first play, the romantic drama in prose La Famille créole, is no less important for its subtle contribution to Louisiana's identity politics. Although the play was published and performed in New Orleans, the newspapers of the time do not indicate anything about how it was received. Ruby van Allen Caulfield, however, suggests the play must have had some

1 For book-length studies on melodrama, see Brooks, 1976; Thomasseau, 1984; and Przybos, 1987. 
degree of success given its multiple performances at the French Theater (van Allen Caulfield, 1929: 171). The French Theater in New Orleans where it was performed was indeed a marker of quality, so it would be reasonable to imagine that Lussan's play met a favourable audience.

The five-act play takes place in 1794. It opens and ends in New Orleans, but the three central acts take place in Paris. In the first act, the Clairvilles (father Clairville, mother Clémence, daughters Cécile and Marie, and Clairville's younger brother Alphonse) have just arrived in New Orleans from Saint-Domingue. Initially uncertain about settling in Louisiana, the Clairvilles think about moving to France instead. After preparing for their return to France during the first act, Clairville the father, and his daughter Marie spend the next three acts in Paris. The father hopes to find a way to regain some of his fortune so as to ensure his family's future, and to bring the rest of the family to Paris. While in Paris, however, the father and daughter are falsely accused of treason by revolutionaries and barely escape the guillotine. Following their near-death experience in Paris, they quickly return to Louisiana, which has become by then their only place of salvation.

Beyond reminding its Louisiana audience of the very presence of the Saint-Domingue Creole community that was beginning to be forgotten, the play also defines the Creole community as both deeply Louisianian and American, while avoiding the political issues of slavery and loyalty that plagued Louisiana politics at the time. By presenting a family of planter refugees from revolutionary Saint-Domingue as primarily refugees from revolutionary France fleeing political persecution, the play absolves them of their likely past as slaveholders in the Caribbean and of any revolutionary tendencies. As a result, the family appears as politically innocent, neither linked to the highly political issue of slavery in late eighteenth- to early nineteenth-century Louisiana, nor belonging to the feared category of revolutionaries. The refugees become paragons of injustice in need of Louisiana/America for their salvation. The play thus inscribes the story of the Saint-Domingue refugees in Louisiana into the traditional American story of the United States as a beacon on the hill for refugees fleeing political persecution.

\section{Saint-Domingue: A Place of Oblivion}

Although the family is identified very early on as a family of a 'colon de Saint-Domingue réfugié à la Nouvelle Orléans' (Lussan, 1837: I. i. 1) ${ }^{2}$

2 Owing to the peculiarities of the page numbering of this play, currently only 
[colonial refugee from Saint-Domingue to New Orleans], Saint-Domingue is largely absent from the play's dialogues. However, it is implicitly present in the family's behaviour. For instance, Clairville, the father, enters the stage as a man in shock: his hand shakes as he lifts it. He reveals 'une émotion croissante' (I. i. 2) [a growing emotion] and sheds a tear listening to his brother, who worries about him. But far from lingering on the past, he is ready to face his destiny and move on. He repeats several times that he is ready to read the much-awaited letter from France that is to inform him of the state of his finances, and ready to act upon what it says: 'Je suis bien préparé [...] Je te le répète. Je suis bien préparé!' (I. i. 2) [I am really ready [...] I am telling you again. I am really ready]. The father's insistence on his own readiness to face his future, although obviously mixed in with clear signs of anxiety, reveals how much he is ready to forget about his past in Saint-Domingue.

The rest of the text confirms his desire to forget about the past, if not altogether ignore it, by not allowing the issue of colonialism and the subsequent slave rebellion on the island to enter the narrative, in spite of these events being the catalyst for Clairville's new life. Indeed, the textual references to colonial life in Saint-Domingue amount to barely noticeable hints about the life that was lost: wealth, happiness, a plantation, 'une existence douce et calme' (I. ii. 7) [a sweet and calm existence]. There are only three other references to their life as colonial planters in Saint-Domingue. Furthermore, as if further to distance the Clairvilles from their Saint-Domingue memories, these references are made either for or by Adolphe, who is not a Creole himself but a Frenchman that Marie (Clairville's daughter) is to marry. In the first act, when Clairville remembers the unforgettable 'soirées de l'habitation' (I. i. 4) [evenings at the plantation] they left behind, he is actually quoting Adolphe. In the second act, when Marie devotes a short passage to the beauty of Saint-Domingue, she reveals she only enjoyed these sites thanks to and with her fiancé Adolphe. Far from remembering the island for itself, she remembers it as a wonderful place only when Adolphe was there with her:

Oh! Mon bonheur t'avait suivi! ... [...] cette mer bleue, ces beaux sites de ma patrie, que j'aimais tant à admirer avec toi sur le morne, avaient perdu tous leurs charmes! Je donnai la liberté à mes oiseaux; mes fleurs [...] se fanèrent [...] Une profonde rêverie s'empara de mes sens! [...] Je croyais

available on the Internet, textual references are given in upper- and lower-case Roman numerals to indicate act and scene followed by a page number in Arabic numerals. 
être encore dans le jardin, assise sur le tertre! ... J'étais dans le cimetière,

à genoux sur la tombe de ma sœur Hermine! (II. iii. 5; emphasis added) ${ }^{3}$

As Marie reveals how she stopped caring for the beauties of the island as soon as her French fiancé left, one realizes how little she seemed to care for the island itself, and how much her own relationship with the island was more dependent upon Adolphe than on her own experience of the reality that surrounded her.

The Clairvilles' apparent detachment from Saint-Domingue is further evidenced in the text when the last reference to colonial times there comes directly from Adolphe himself. As Adolphe and Marie are about to die under the guillotine in Paris, he briefly cheers Marie up by telling her they will relive 'nos délicieuses soirées à St. Domingue' (IV. v. 10) [our delightful evenings in Saint-Domingue] in heaven soon after their death. This last mention of Saint-Domingue confirms how the island is, for both Marie the refugee and Adolphe the Frenchman, if not altogether forgotten, at least no longer in existence.

Like the colonial memories about the island, references to the Saint-Domingue revolution barely enter the text and are even more elliptic. Accounts of the revolution amount to four brief references that do not always betray any emotion about the events. In fact, the Saint-Domingue revolution always appears under the guise of euphemisms: never referred to as a revolution or a rebellion, it has become 'les événements de St. Domingue' (I. i. 1) [Saint-Domingue's events], 'notre départ de St. Domingue' (I. iv. 10) [our departure from Saint-Domingue], 'nos malheurs' (II. iii. 5) [our misfortunes], 'nos désastres' (III. iii. 4) [our calamities]. Such references are never contextualized, nor followed by any additional information about the Clairvilles' precipitous departure from the island.

The silence of the Clairville family about Saint-Domingue, as well as the lack of emotion when they do refer to it, may of course be a facade to hide great pain: a way to contain the events so as to render them more bearable emotionally. Such an interpretation, however, is deeply inconsistent with the characters and the rest of the play. Lack of emotions is indeed neither the hallmark of the Clairville family nor a feature of romantic drama, the genre

3 This and all subsequent quotations from this source were translated by the author of this chapter. 'Alas! My happiness followed you! ... [...] this blue sea, my country's beautiful sites that I loved so much to admire with you on the hill, had lost all their charms! I gave my birds their freedom; my flowers [...] died [...] A deep state of dream overtook my senses! [...] I would think I was still in the garden, sitting on the hillock! ... I was in the cemetery, kneeling on my sister Hermine's tomb!' 
to which the play belongs. In fact, emotions abound in this play, but they are never about Saint-Domingue and always about Paris. During the course of the father and daughter's stay in Paris, which the play focuses on, they both display a wide range of feelings: from the satisfaction of Clairville who has recovered most of his fortune (II. i) and Marie's bliss at the prospect of her wedding (II. ii-iii) to their fear, anger, suffering and despair upon being wrongly imprisoned, accused of treason and about to face the guillotine (II. vi-vii; III. v; III viii; IV. iii). This emotional turmoil continues until the end of the play: after the relief of escaping from the guillotine at the last minute by some deus ex machina intervention, they are saddened anew by the news of the mother's madness once back in New Orleans, and happy again when she is finally cured.

This wide range of emotions is typical of the genre of the play. As romantic drama (or melodrama), it is written with the explicit purpose to stir emotions. Epitomized by Victor Hugo's 1830 romantic play Hernani, romantic drama, unlike classical drama, mixes tone (tragedy, comedy, drama) and focus (human, social, historical) while stirring emotions around an innocent hero or heroine who has become the victim of a great injustice. ${ }^{4}$ Typical of the genre, Lussan's play reveals the series of injustices suffered by the Clairvilles, and displays their emotional responses to them. However, his text only allows the display of emotions to narrate the Clairvilles' exile from Paris, but refuses to offer a similar emotional space to reveal anything about their departure from Saint-Domingue. Upon closer scrutiny, even Clairville's initial deeply felt emotion as he first enters the stage is not about his feeling of loss for the island but about his lost fortune. Clairville is indeed more worried about getting his money back from his French business partners than about the island he left behind, suggesting that he used the island mostly to turn a profit. While the scarcity of references to and the lack of emotions towards Saint-Domingue effectively banish the family's Caribbean past from the narrative, these omissions stand out even more strongly once we see the family's reaction to being expelled from France. Whether the Clairvilles' silence over their life in and departure from Saint-Domingue is the result of trauma, or genuine callousness, we cannot know for sure. What we do know is that the expulsion of their past life on the island from the play effectively uproots this family from Saint-Domingue and from their slave-holding past. In the text, the colonial past is past and Saint-Domingue is relegated into

4 Although melodrama and romantic drama can be used interchangeably (as in this chapter), Brooks saw romantic drama as the nineteenth-century continuation of melodrama, which started during the French Revolution in the late eighteenth century. 
oblivion: the place of loss is symbolically a lost place, one to which the Clairvilles will never return.

The muted reaction of the Clairville family towards their life in and departure from Saint-Domingue is clearly revisionist as it conflicts with what we know about how refugees actually behaved. For many refugees from Saint-Domingue in New Orleans, ties to the island remained alive for many years, even decades. Until 1825 when Charles X ordered Haiti to repay its former colonists some of the money they lost in the Saint-Domingue revolution, many Saint-Domingue refugees were still hoping for a return to the island. It is only in 1825 and after, not as early as in 1794 as the play suggests, that Saint-Domingue refugees in New Orleans really severed all ties with the island. Older refugees and their memories of the island were dying, and their wills mentioning properties on the island clearly could not be honoured (Dessens, 2007: 61-62).

Although the text severs the refugees' ties to Saint-Domingue earlier in time, it cannot readily present the Clairvilles as Louisianians until it also rids them of their allegiance to France. The text takes much longer (three acts to be exact) to separate the Clairville family from its French roots, but it does so nonetheless.

\section{Paris: From Salvation to Hell}

The place that dominates the play is neither Saint-Domingue nor New Orleans, but Paris, where the three central acts of the play take place. One could even say that the first act that takes place in New Orleans is already so much about Paris that New Orleans is only truly present in the last act, while Paris occupies the other four. Paris initially appears as the only place where the family can recover, financially but also emotionally, from its losses in Saint-Domingue. The play opens in a modest apartment in New Orleans shortly after the Clairvilles' escape from Saint-Domingue in 1794. Alphonse, Clairville's younger brother, is excited by the arrival of several letters from France addressed to his older brother: 'Enfin! Des nouvelles de France' (I. i. 1) [At last! Some news from France]. As Clairville goes through his mail from France, a list of their contacts in France reveals the strong links (both familial and professional) the Saint-Domingue refugees have with France, all the while underlining the absence of such links with New Orleans. Clairville glances at a letter from a cousin, another from a friend and commandant, before opening the much awaited letter from Germont, a friend and 'négociant en produits coloniaux' (I. i. 3) [trader in products from the colonies] who is to inform him of the status of his finances.

Germont's letter seems reassuring regarding Clairville's ability to recover 
some of his money from former business partners. However, the letter is also terrifying. Sparing no detail, Germont describes the horrors of the French Revolution and the dangers that await Clairville should he decide to go to Paris to claim the money he lost from the French merchants he did business with while in Saint-Domingue. Germont insists on the chaos, the guillotine, the heads that roll daily, the anarchy and the injustices. But nothing discourages Clairville, who quickly becomes obsessed with leaving for Paris, as he sees the latter as the only place for his family's salvation. Refusing to linger on his recent past in Saint-Domingue, or on his present situation in New Orleans, Clairville envisions Paris as the only place where he can ensure a stable future for his family. For him, staying even temporarily in New Orleans would condemn him to poverty (I. ii. 7). By comparison, leaving for Paris is, he explains, a double necessity: one that will allow him to get a hold of his finances, and to secure a husband for his daughter Marie, who is to marry Adolphe, Germont's son. This double goal reveals the intertwined nature of the emotional and financial ties that link Clairville to France. This double bind, however, initially seems to leave no room for New Orleans and, indeed, the family as a whole does not envision a future anywhere else but in Paris.

Clairville's love for Paris is indeed shared by the rest of the family. When he announces his trip to Paris with Marie (I. iii.), during which the mother Clémence and sister Cécile are to stay behind and join them later, Marie is sad for the duo who were so eager to see France: 'Pauvre mère! Pauvre Cécile! ... comme elles vont être douloureusement affectées en apprenant cela! ... c'est que, vraiment, nos parts ne sont pas égales! ... Pour moi tout le bonheur! Pour elles la douleur!' (I. iii. 8). ${ }^{5}$ Clairville's preference for Paris is thus not a personal preference but is shared by the family.

The first three scenes of the second act confirm Paris as the place of salvation for the family. We learn how in less than two months in Paris Clairville was lucky to recover most of his finances, and his daughter's wedding is now imminent. We even enjoy a romantic scene between Marie and her fiancé Adolphe. Everything suggests that the family will soon reunite in Paris and live happily ever after.

This fairy tale ends abruptly, however, when Clairville and his daughter are suddenly involved in France's political turmoil. In the scene following Adolphe and Marie's blissfully romantic moment, the chaos of revolutionary Paris emerges and in less than one scene everything the Clairvilles recovered

5 'Poor mother! Poor Cécile! ... how painfully saddened they will be when they know! ... it's that, really, our shares are not equal! ... For me only happiness! For them pain!' 
is threatened: their finances, the wedding, not to mention their lives. This reversal of fortunes emerges from a twist in the financial and emotional ties that linked the Clairvilles back to Paris. Bernard, Clairville's former administrator, refuses to refund Clairville's lost money and announces that, unless Marie marries him, Clairville will be denounced as a traitor, imprisoned and very likely killed.

The reversal of Clairville's fate radically changes his perspective on Paris. As revolutionary Paris enters his life, Clairville starts seeing Paris as a place of utter chaos. From a city of salvation, Paris becomes a city of 'pygmées audacieux et cruels' (II. vi. 15) [bold and cruel pygmies], governed by illiterates (II. viii.16) without civilization, justice, 'urbanité' [politeness] or 'galanterie' [gallantry] (III. ii. 3). Ironically, the vocabulary used to describe Paris ('pygmées', 'sans civilisation') strangely mirrors that typically used by some colonists to describe native and enslaved populations in the Caribbean. As Lussan's text transfers onto French revolutionaries the critiques uttered against Saint-Domingue revolutionaries, the play transforms the Clairvilles into clear victims of an injustice and political oppression. They are not slaveholders who were intrinsically linked to the slaves that rebelled against them. Instead, they become utterly innocent victims of a turmoil they never helped create. After all, the play makes sure to remind us that they are not aristocrats, that their name is 'Clairville', not the noble 'de Clairville' (III. iii. 4). It also reaffirms that the Clairvilles are not royalists (III. iii. 15). Neither nobles nor royalists, their imprisonment in France's revolutionary prisons is presented as an absolute injustice. Their status as innocent victims from France's revolution further helps the text insert them in the narrative of Louisiana/America as the land of the free for people fleeing persecution at home. But Lussan's text goes even further. To ensure the undeniable insertion of the Creole family into Louisiana society, Lussan not only rids the Clairvilles of their multiple cultural allegiances to Saint-Domingue and France but also, as we will see, its rids them of any political ideology that could have been seen as controversial for the times in Louisiana.

\section{Louisiana: Le nouvel Éden}

As death dominates Paris, the city can no longer be the place for the Clairvilles' future. It is Louisiana that soon emerges as their only place of salvation. The quick degradation of the image of Paris is mirrored by an equally quick emergence of Louisiana as the only place of peace and civilization between Saint-Domingue and France. Indeed, just as Clairville begins to feel threatened in Paris, he starts using a new discourse that anchors him in Louisiana and separates him from France: faced with the terrifying news 
of his imminent imprisonment, Clairville lets out a 'Mais c'est affreux! ... c'est à préférer mille fois nos forêts à votre civilisation!' (II. vii. 15; emphasis added) [But it is horrible! ... it makes one prefer a thousand times more our forests to your civilization!], using the possessive adjectives 'nos' [our] and 'votre' [your] to separate himself from France while anchoring himself in Louisiana. Although Adolphe chastises him for being unjust 'pour notre malheureuse patrie' (II. vii. 15) [for our unfortunate country], re-anchoring Clairville in France with yet another possessive, Clairville's symbolic loss of his French nationality is unmistakable. In fact, others no longer see him as French. When interrogated in prison, revolutionaries ask him why he came to France, a question that Clairville interprets as meaning he is no longer French if he needs a reason to go to France (III. vii. 14). Later on, when the Duke de Jumonville, who shares Clairville's prison cell, thinks of Clairville and his daughter, he hopes they can return to their country ('leur pays') as quickly as possible (IV. iv. 6), confirming that Clairville is no longer seen as French in the eyes of both revolutionary and pre-revolutionary France.

Clairville is not alone in experiencing a change of heart for Louisiana. Marie, who was so excited at the prospect of leaving Louisiana for Paris, begins to have feelings for the region even before the tumultuous events in Paris. While envisioning her future with Adolphe, she expresses her strong desire to live close to her mother, sister and uncle left in New Orleans. Adolphe reassures her not by envisioning that everyone settles in Paris but by thinking about settling in New Orleans next to them, buying a plantation, and ensuring their legacy as 'la mère et le médecin des malheureux' (II. iii. 6) [the mother and the doctor of the poor] (Adolphe being a young doctor). Although Adolphe's idea initially appeared as the fantasy of a young couple, it quickly becomes revelatory of the emotional ties that have begun to blossom between the Clairvilles and New Orleans.

As the horrors of Paris literally reject and repulse the Clairvilles, Louisiana becomes the antithesis of Paris, and the new hope for their salvation. While Paris is chaos and death, Louisiana is peace and life. Ironically, we encounter the heavenly nature of Louisiana literally at the moment the Clairvilles enter their prison cell in Paris. As they step in, their cell companion, the Duke de Jumonville, reads aloud a passage from Chateaubriand's Le Génie du christianisme ${ }^{6}$ [The Genius of Christianity], which presents Louisiana as heaven on earth: 'une délicieuse contrée que les habitants de l'Amérique appellent le nouvel Éden' (III. i. 1) [a delightful region that inhabitants of

6 This is an anachronism since Chateaubriand's text was published in 1802 and Lussan's play, although written in 1837, takes place in 1794, eight years before Chateaubriand published his text. 
America call the new Eden], an expanse extremely fertile thanks to the rich waters of the Meschacebe, a region where 'la grâce est toujours unie à la magnificence' (III. i. 1) [grace is always linked to magnificence]. This passage about Louisiana's natural wealth and abundance of life contrasts sharply with the quote from Clairville's last letter to his wife, in which he describes Paris as utterly disordered, and France as forever lost (III. viii. 15). Ironically, this very description is also the kind of discourse that might previously have been used by colonists to describe Saint-Domingue. ${ }^{7}$ Such an exotic discourse was also often used to attract potential settlers to newly colonized regions and it seems to perform a similar role in the text as the Clairvilles begin to consider settling in Louisiana.

As the play presents the Saint-Domingue refugees as twice exiled, once from the Caribbean, once from France, it strips them of any cultural allegiance to another country. But, most importantly perhaps, it cleanses them of any political ideology that could have rendered them undesirable in Louisiana at the turn of the nineteenth century. Neither royalists nor revolutionaries, neither pro- nor anti-slavery, the Clairvilles paradoxically become apolitical political refugees. In other words, Lussan's play carefully avoids directly addressing the dominant political issues in Louisiana during the same forty years that span the play's story and its publication (1794-1837). Nonetheless, by rendering his characters apolitical, Lussan addresses these issues indirectly.

The first of these is the issue of slavery. On the one hand, the 1791 Saint-Domingue insurrection and the subsequent mass immigration of Saint-Domingue refugees with slaves to the United States gave rise to the fear that such an insurrection could spread to slaves in the southern United States. The fear initially ran so deep that Louisiana Governor Carondelet (1791-7) banned the import of Saint-Domingue black slaves in 1792, preventing Saint-Domingue refugees with slaves from settling in Louisiana. The following year, Thomas Jefferson himself (then US Secretary of State and in favour of gradual rather than sudden emancipation) issued 'an apocalyptic warning of the danger of slave rebellion' (Matthewson, 1995: 216). Several attempted insurrections in the following years only seemed to justify Louisiana's growing fear of an uprising. In early April 1795, there was a failed attempt at a rebellion organized in Pointe Coupée, Louisiana (Baur, 1970: 403). In March 1796, a slave rebellion scare arose on the German Coast in Louisiana. In 1800 and 1802, in Virginia, and in 1804 and 1805, in Louisiana, more slave rebellions were discovered and suppressed (Matthewson, 1995: 218; Dormon, 1977: 392). In 1811, the January slave uprising on the German Coast, the 'largest

\footnotetext{
7 I would like to thank Martin Munro for this remark.
} 
slave revolt in US history' was led by Charles Deslondes, a mulatto from Saint-Domingue (Thompson, 1992: 5-8), and 'modeled its organization after the [Saint-Domingue] revolutionaries' (Kastor, 2001: 839). In 1822, the revolt organized by Denmark Vesey in Charleston, South Carolina, was discovered one day before it was to be launched. Finally, the 1831 Virginia insurrection organized by Nat Turner followed by an 1835 aborted insurrection further contributed to a permanent 'siege mentality' in the South in general and in Louisiana in particular (Rodriguez, 1992: 415). Although fear of rebellions came in 'spurts' in the South, overall, the fear of an insurrection was ever present (Dormon, 1977: 392; Matthewson, 1995: 218).

Lussan's 1837 play was thus written and performed in a politically charged period in Louisiana, a period during which slavery as an institution was beginning to show serious signs of decline. Fear of growing pro-abolitionist sentiments was compounded in Louisiana by the abolition of slavery in most of the British Empire in 1834, and by the rise of pro-abolitionist sentiments in France. Literature was certainly not immune from politics and many French Romantics (Lussan's contemporaries) repeatedly displayed pro-abolitionist sentiments in their writings. ${ }^{8}$ Eventually, French politicians voted to abolish slavery in 1848, ten years after Lussan's play. Paradoxically, this domestic and international pro-abolitionist context helps account for Lussan's creation of characters entirely detached from the issue of slavery. By silencing the Clairvilles' past as slaveholders from the island of Saint-Domingue, and by presenting them as not having imported slaves with them to Louisiana, the play severs any link whatsoever between the Clairvilles and the issue of slavery that permeated Louisianian politics at the turn of the century. This political decision on Lussan's part helped render the Clairvilles less controversial as new Louisianians.

The play further insists on the apolitical nature of the Clairvilles as it details their expulsion from revolutionary France, and, by extension, removes them from the feared category of French revolutionaries. This was yet another important aspect to consider in ensuring a refugee's acceptance into Louisianian society of the time. Indeed, fear of an insurrection in the South did not just focus on blacks and freemen and women of colour. It also included whites, particularly Northerners in favour of the abolition of slavery, and partisans of the French Revolution. In 1790s Louisiana, Governor

8 Claire de Duras' Ourika in 1823 and Victor Hugo's Bug-Jargal in 1826 reveal how both men and women writers in France were concerned by the issue of slavery in the early nineteenth century. For more on the topic of French Romantics and slavery, see O'Connell, 1973. For more on the topic of women writers and slavery, see Kadish and Massardier-Kenney, 1994. 
Carondelet and his successor Governor Miró feared French partisans so much that they 'used propaganda [...] to portray the French Revolution at its worst' (Hanger, 1993b: 7). Fear of those partisans became so intense that, according to Hanger, 'colonial officials [...] accused, jailed, and deported many more whites than free blacks for seditious behavior in the 1790s' (ibid.: 12). By creating characters that fell victim to French revolutionaries, Lussan's play further ensures that his Creole refugees appear as politically non-threatening as possible.

Apolitical yet persecuted, the Clairvilles are bound to appear loyal to Louisiana, thus erasing another worry among American politicians: although French speaking, the Clairvilles offer a portrait of Creoles that reassures Anglo-American politicians who were worried by the perceived lack of 'loyalty and national identity of a [Louisiana] population composed primarily of people born under French and Spanish colonial rule' (Kastor, 2001: 828). Louisiana's large Gallic population was indeed often seen as not American enough by Anglo-Americans. If their language was one issue, their threetiered society was another. Lussan's play indirectly addresses the latter. By focusing exclusively on white Creoles from Saint-Domingue, when in truth Creoles from Saint-Domingue were a multiracial group composed of whites, black Creoles and Creoles of colour, Lussan modifies another Creole reality to make Saint-Domingue refugees more acceptable for the growing Anglophone majority in Louisiana. The play thus illustrates a major shift in 1830s Louisiana society that occurred in large part in response to the Americanization of Louisiana. ${ }^{9}$ The Americanization of the region meant the rise of new forms of racial division within the multiracial Creole community. White Creoles in search of acceptance by the rising Anglophone population in the region felt under pressure to place clear boundaries between whites and blacks. By not inserting any Creole of colour or black Creole characters in his 'Creole family', Lussan participates in the white Creoles' attempts to re-appropriate the term for themselves at a time when they felt under pressure to adopt the Anglo-American binary division between blacks and whites and abandon their historical, social and cultural ties to black Creoles and Creoles of colour.

\section{Conclusion}

Far from being realistic, La Famille créole is a romantic drama, which, as a rule of the genre, is meant to excite emotions. To that end, it is clearly Manichean in its world view, as it presents Paris as hell and Louisiana

9 Louisiana became American territory in 1804, and part of the Union in 1812. 
as heaven on earth, and is melodramatic in tone as it alternates between tragedy, comedy, and drama, and melodramatic in content as it alternates between historical, social, and emotional drama. However entertaining its melodramatic quality might have been for the audience at the time, the play, however, did not escape politics. As it carefully removes any political and cultural layers that could render the Clairvilles controversial, the play portrays the 'Creole family' as desirable Louisianians and even as desirable Americans.

Lussan's 1837 play about Saint-Domingue refugees from the 1790s thus ironically illustrates the changing understanding of what it meant to be Creole in Louisiana by the 1830s. While Saint-Domingue refugees initially redefined Creole identity in Louisiana in the early days of their arrival, Lussan's refugees become emblematic of Louisiana's changing understanding of its own Creole identity some forty years later. As the region faced several political crises (around the issue of slavery on the one hand, and loyalty to the federal government on the other), the Creoles certainly felt the need for a respite from politics. Lussan's play allows such an audience to escape politics by presenting a Creole family that is seemingly apolitical. In the process, however, the play's many silences speak volumes on the very issues that obsessed Louisiana at the time. By focusing on the need for a family of refugees to let go of its ties to both Saint-Domingue and France, the Creoles' French and Franco-Caribbean roots (and their subsequent links to the issues of slavery and revolution) are highlighted only to be erased. In the process, the refugees (and the Creoles they pretend to represent) are rendered more compelling as victims (since they clearly appear to be fleeing France because of unjust persecution rather than Saint-Domingue because of their position as planters), and more compelling as new Americans (since they had to break their ties to any other country in order to survive).

\section{Works Cited}

Baur, John E. 1970. 'International Repercussions of the Haitian Revolution'. The Americas 26.4: 394-418.

Binder, Wolfgang (ed.). 1998. Creoles and Cajuns: French Louisiana - La Louisiane Française. Frankfurt: Peter Lang.

Brasseaux, Carl A. 2005. French, Cajun, Creole, Houma: A Primer on Francophone Louisiana. Baton Rouge: Louisiana State University Press.

Brasseaux, Carl A., and Glenn R. Conrad (eds). 1992. The Road to Louisiana: The Saint-Domingue Refugees, 1792-1809. Lafayette: Center for Louisiana Studies. Brooks, Peter. 1976. The Melodramatic Imagination: Balzac, Henry James, 
Melodrama and the Mode of Excess. New Haven, CT and London: Yale University Press.

Cable, Georges Washington. 1884. The Creoles of Louisiana. NY: Charles Scribner's Sons.

Chateaubriand, François-René. 1802. Génie du christianisme, ou beautés de la religion chrétienne. Vol. 3. Paris: Migneret.

de Durfort Duras, Claire. 1823. Ourika. Paris: De l'Imprimerie royal.

Dessens, Nathalie. 2007. From Saint-Domingue to New Orleans: Migration and Influences. Gainesville: University Press of Florida.

Din, Gilbert C. 1997. 'Carondelet, the Cabildo, and Slaves: Louisiana in 1795'. Louisiana History: The Journal of the Louisiana Historical Association 38.1: 5-28.

Dominguez, Virginia R. 1986. White by Definition: Social Classification in Creole Louisiana. New Brunswick, NJ: Rutgers University Press.

Dormon, James H. 1977. 'The Persistent Specter: Slave Rebellion in Territorial Louisiana'. Louisiana History: The Journal of the Louisiana Historical Association 18.4: 389-404.

Dubois, Sylvie, and Megan Melançon. 2000. ‘Creole Is, Creole Ain’t: Diachronic and Synchronic Attitudes toward Creole Identity in Southern Louisiana'. Language in Society 29.2: 237-58.

Fiehrer, Thomas. 1989. 'Saint-Domingue/Haiti: Louisiana's Caribbean Connection'. Louisiana History: The Journal of the Louisiana Historical Association 30.4: 419-37.

Fortier, Alcée. 1886. 'French Literature in Louisiana'. Transactions and Proceedings of the Modern Language Association of America 2: 31-60.

Hanger, Kimberly S. 1993a. Bounded Lives, Bounded Places: Free Black Society in Colonial New Orleans, 1769-1803. Durham, NC and London: Duke University Press.

—. 1993b. 'Conflicting Loyalties: The French Revolution and Free People of Color in Spanish New Orleans'. Louisiana History: The Journal of the Louisiana Historical Association 34.1: 5-33.

Havard, Gilles, and Cecile Vidal. 2003. Histoire de l'Amérique française. Paris: Flammarion.

Holmes, Jack D. L. 1970. 'The Abortive Slave Revolt at Pointe Coupée, Louisiana, 1795'. Louisiana History: The Journal of the Louisiana Historical Association 11.4: 341-62.

Hugo, Victor. 1826. Bug-Jargal. Paris: Urbain Canel, libraire, rue Saint-Germaindes-Prés, n.9.

-. 1830. Hernani. Paris.

Kadish, Doris Y., and Françoise Massardier-Kenney (eds). 1994. Translating 
Slavery: Gender and Race in French Women's Writing, 1783-1823. Kent, OH.: Kent State University Press.

Kastor, Peter J. 2001.“"Motives of Peculiar Urgency”: Local Diplomacy in Louisiana, 1803-1821'. William and Mary Quarterly, Third Series 58.4: 819-48.

Lussan, Auguste. 1837. 'La Famille créole. New Orleans: Fremeaux et Alfred Moret'. $<$ http://www.centenary.edu/french/lussan.htm>. Consulted 7 December 2011.

Matthewson, Tim. 1995. 'Jefferson and Haiti'. Journal of Southern History 61.2: 209-48.

Newton, Lewis William. 1929. 'The Americanization of French Louisiana'. University of Chicago Ph.D. thesis. Published 1980. New York: Arno Press.

O'Connell, David. 1973. 'The Black Hero in French Romantic Fiction'. Studies in Romanticism: Aspects of European Romanticism 12.2: 516-29.

Przybos, Julia. 1984. 'La Conscience populaire et le mélodrame en France dans la première moitié du dix-neuvième siècle’. French Review 57.3: 300-08.

—. 1987. L'Entreprise mélodramatique. Paris: Corti.

Rodriguez, Junius P. 1992. 'Always "En Garde”: The Effects of Slave Insurrection upon the Louisiana Mentality, 1811-1815'. Louisiana History: The Journal of the Louisiana Historical Association 33.4: 399-416.

Thomasseau, Jean-Marie. 1984. Le Mélodrame. Paris: Presses universitaires de France.

Thompson, Thomas Marshall. 1992. 'National Newspaper and Legislative Reactions to Louisiana's Deslondes Slave Revolt of 1811'. Louisiana History: The Journal of the Louisiana Historical Association 33.1: 5-29.

van Allen Caulfield, Ruby. 1929. French Literature of Louisiana. NY: Institute of French Studies, Columbia University. 


\title{
Caribbean and Creole in New Orleans
}

\author{
Angel Adams Parham
}

While most of the United States has historically been dominated by a 'black/white' racial binary, New Orleans - as well as many other parts of Louisiana - has long been shaped by a tripartite division that included a thriving community of free people of colour who were socially in-between and distinct from enslaved blacks and free whites. This division was nurtured by Louisiana's Spanish and French colonial rulers and then significantly reinvigorated by the migration of nearly 10,000 refugees from the Haitian Revolution, who fled their first refuge in eastern Cuba to settle in New Orleans in 1809. In the research discussed here I examine how these historical ties to the Caribbean continue to shape the way many in New Orleans understand their culture and describe their racial and ethnic identification. I argue that in order to understand its racial and ethnic present, New Orleans must be examined within the larger history and context of the Americas.

This research is based on three years of ethnographic research and thirtyseven in-depth interviews with genealogists who have Louisiana Creole ancestry that extends back to Saint-Domingue/Haiti. I have chosen to work with genealogists because genealogical research encourages participants to investigate the intersection between public histories and personal identities (see Hareven, 1978; Ball, 1998; Hall, 1998; Tyler, 2005). Because individuals with Creole ancestry are a cultural minority within the larger US community, remembering the ancestors either through informal recounting at family gatherings or through carefully documented research serves to keep alive a unique and distinctive history that is little known among those outside of 
the group. Despite the importance of genealogical activity for many Creoles, however, there is no ethnographic work that directly explores the question of how this activity informs the maintenance of Creole identities.

Listening to the stories of these genealogists has also made it possible to examine how individuals incorporate regional histories and cultures into their understandings of who they are. It is especially important to understand this process within regions of the United States that have a significant historical relationship with other regions in the circum-Caribbean. Paying closer attention to the transnational history and character of many US regions may inform and potentially transform our public debates about what it means to be 'American'. This public debate over national identity continues to be relevant and to generate contention as US citizens discuss issues like immigration policy, English-only language laws, reception of immigrants and other related questions. Genealogical research that crosses borders raises awareness among everyday people of the transnational social and cultural influences that have made the United States what it is today. During the course of this work it has become clear, for instance, that historical linkages to Saint-Domingue/Haiti have not been forgotten in Louisiana. Instead, these connections provide some of the cultural materials respondents use to make sense of who they are.

\section{French, Spanish and Caribbean: The Many Roots of New Orleans}

New Orleans is often seen as being 'different'. This is as true today as it was in 1819 when Benjamin Henry Latrobe visited and wrote that everything 'had an odd look'. He found it difficult 'not to stare at [a] sight wholly new even to one who has traveled much in Europe and America' (Johnson, 1995: 1). Today, New Orleans continues to stand out for its unique cultural landscape, and it is often called the northernmost point of the Caribbean. The city's history helps to account for this linkage in the public imagination of New Orleans with the Caribbean. As part of the Louisiana territory during its colonial era, New Orleans was alternately part of the French and Spanish colonial regimes. Its history is thus intimately tied to the histories of the Spanishand French-speaking Caribbean. This diverse colonial heritage has shaped understandings of race and ethnicity in ways that are unique compared to other parts of the United States. In order to understand why this is the case, we must consider the kinds of racial practices carried out under the French and the Spanish in colonial Louisiana. We will then contrast this with social and cultural transformations associated with race that occurred during the period of Americanization that followed the Louisiana Purchase in 1803. 
Finally, we will consider how this legacy continues to inform understandings of race and ethnicity in New Orleans.

\section{Racial Mixture during the French Period, 1718-1763}

Louisiana was a difficult place for the many settlers and residents who embarked upon life in the colony. During its early period it was quite poor, and compared to colonies like Saint-Domingue to the south it was considered to be a cultural backwater. Socially, white men found a significant lack of white sexual partners. As a result, they turned to African and Native American women, with whom they entered into either forced or consensual sexual relationships.

In some cases, the interracial relationships between white men and women of African descent were conducted within the framework of an informal institution called plaçage. In a plaçage relationship, the white man agreed to provide a certain level of economic support to the woman and the offspring that came from the union (for more on this practice, see Foner, 1970 and Martin, 2000). These were complex relationships that could be characterized on a continuum from coercion to consent. In some cases, there was more coercion than consent. In others, however, there was a mutual agreement between the man and the woman to enter into and sustain the relationship. Although the relationships could not be legalized because the law forbade mixed marriages, the system of plaçage became an accepted social institution in the colony.

In many cases, children born of interracial unions remained enslaved because their mother was enslaved; the condition of freedom or enslavement was inherited maternally. In other cases, however, the children born of such relationships were given their freedom by their white father. These children, especially the boys, might even have been sent to France for a formal education. This practice led to a small population of free people of colour who were often quite skilled, well educated and financially well-off. The overall population of free people of colour increased slowly under the French because even if a slave had the money to purchase his or her freedom the owner had the authority to refuse the sale. It was not until the Spanish period that the population of free people of colour increased significantly.

\section{Racial Mixture during the Spanish Period, 1763-1803}

The French ceded Louisiana to Spain in the 1763 Treaty of Paris, which ended the Seven Years War. At the time of the legal transition of power, Spanish authorities were working hard to re-establish control over their 
war-ravaged country. Consequently, the regime was slow to send leaders to the newly acquired territory. It was not until 1765 that the Spanish government sent governor Antonio de Ulloa y de la Torre Guiral to the colony with orders to allow French laws and customs to stay in place. The inhabitants of Louisiana did not, however, respond well to Ulloa's rule. He was viewed as indecisive and unwilling to exert control. As a result, French planters and merchants rose up and banished Ulloa from the colony. In response, the Spanish finally established decisive rule over Louisiana by sending a new governor, Alejandro O'Reilly, along with 2,100 troops, to restore order. ${ }^{1}$

The system of plaçage between white men and women of African descent continued under Spanish control. To this system was added the Spanish practice of coartación, which significantly shaped the racial landscape in Louisiana. Under this practice, slaves had the legal right to purchase themselves if they could come up with their purchase price. If the master was amenable to the purchase, he could set the price and the slave would pay it. If the master was reluctant to allow the slave to purchase his or her freedom, then the courts could intervene and set what was considered to be a fair market price.

This contrasts greatly with the practice under the French. In the French system, a slave could ask to purchase himself or herself, but he or she could not use the courts to compel the owner to accept payment in return for freedom. This right of coartación made it much easier for slaves to purchase their own freedom and many took advantage of it. The exercise of coartación added to the size and strength of the population of free people of colour in Louisiana.

\section{Race in Anglo-American Louisiana, 1803 and Beyond}

While there were differences in the approaches the French and the Spanish took to regulating interracial relationships, the two regimes had more similarities than differences, especially in comparison to the changes imposed by the Anglo-Americans. The French and Spanish colonial regimes had in common the following: a continuum of racial categories; a relatively high tolerance for interracial relationships; a relatively high tolerance for people of colour in positions of wealth and power. These characteristics of the French and Spanish systems allowed for a certain fluidity in racial categories and identities. There was room - especially in Spanish Louisiana - for people of colour - both enslaved and free - to improve their social

\footnotetext{
1 This summary is indebted to Hanger, 1993a: 7-8.
} 
status. This situation would begin to change with the 1803 Louisiana Purchase and the subsequent Americanization which took place across the territory.

The Anglo-Americans who took control of Louisiana were shocked by the cultural and racial practices they found once they got there. In New Orleans, for instance, they found what they considered to be lax supervision of slaves and a relaxed approach to religion. In his work on Congo Square, Jerah Johnson summarizes the perception of Anglo-American residents newly arrived to New Orleans in the early nineteenth century. He writes:

Benjamin Latrobe's reaction was typical. What he saw in the square prompted him to write a long and altogether disapproving entry in his journal [...] on the Creole mode of Sunday observance. And he betrayed his amazement and apprehension at the sight of five or six hundred unsupervised slaves assembled for dancing when he added, in a tone of relief, 'there was not the least disorder among the crowd, nor do I learn on enquiry, that these weekly meeting of negroes have ever produced any mischief.' (Johnson, 1995: 36)

American visitors were also shocked and quite concerned to see free people of colour carrying arms freely in the city and interacting freely and intimately with slaves. As far as they were concerned, this was a situation ripe for rebellion and violence. In response to these 'dangerous' racial practices, the Anglo-Americans attempted to corral the lax and rowdy New Orleanians into racial and cultural categories with which they were more comfortable.

The efforts to Americanize Louisianians were very much resisted by each of the three major social groups. Free people of colour stood to lose their special intermediary status if the Anglo-American preference for a bifurcated racial structure were instituted in place of the more flexible tripartite system under which they had flourished. As far as Anglo-Americans were concerned, anyone with discernible African features or skin colouring - however moderate - was black and little better than those who were enslaved. White Louisianians also resisted adapting to the language, culture and ways of the mainly Protestant Anglo-Americans. They drew clear distinctions between 'Creoles' - who had been born in the colony before 1803 and 'les Américains' who poured into the territory following the Louisiana Purchase. ${ }^{2}$ Finally, the slaves native to Louisiana before the Purchase also had much at stake under the process of Americanization. They were at risk of losing their relative

2 For more on the tensions between these two groups, see Lachance, 1992 and Tregle, 1992. 
freedom to move about on their own and to gather in places like Congo Square for marketing and recreation. Fortunately for these Creoles - black and white, enslaved and free - 1809 brought a development that would dramatically slow the process of Americanization.

\section{The 1809 Migration of Saint-Domingue Refugees}

In 1808, France invaded Spain in an aggression that was part of what is known as the Peninsular War. This was a struggle between France and the allied powers of Spain, Britain and Portugal for control over the Iberian Peninsula. These political troubles between France and Spain ricocheted across the Atlantic and ultimately impacted the Americanization process in New Orleans.

In order to understand why this is the case, we must go back to the year 1791 in the French colony of Saint-Domingue, which is known today of course as Haiti. In August 1791, a network of slaves organized an insurrection that began in the northern part of Saint-Domingue and made its way relentlessly across the entire colony. This was the beginning of the Haitian Revolution. Thirteen years later, on 1 January 1804, black leaders in the colony declared victory against the French and claimed their independence.

During the course of the thirteen-year revolution, thousands of whites and free people of colour fled Saint-Domingue and took their slaves with them. A good number of these refugees ended up on the neighbouring island of Cuba. There they did their best to reconstruct their lives until hostilities broke out between France and Spain in 1808. Once this occurred, the Spanish governors of Cuba looked upon the French-allied refugees in their midst with great suspicion. The Saint-Domingue refugees were required to renounce their ties to France or to leave Cuba. Many chose to flee the Spanish colony. As they considered where to go, Louisiana, with its French heritage, language and culture, was an inviting choice.

Nearly 10,000 Saint-Domingue refugees left Cuba and landed on the shores of New Orleans in 1809. In order to put the magnitude of this migration into context, it is important to know that the 1809 population of urban New Orleans before the refugees arrived was only about 10,000. The newcomers nearly doubled the population of the city. This in itself is extraordinary. The situation becomes even more interesting, however, when we consider how the demographic breakdown of the new arrivals shaped the racial and cultural landscape of the city.

Paul Lachance, who reports the figures in Table 1, explains that even though the total population of all of Orleans Parish was 17,000 before the refugees arrived, the population of urban New Orleans was only about 
10,000. This is where we draw the conclusion that the population of New Orleans was nearly doubled by the migration. Another important observation is that this migration also more than doubled the population of free people of colour. This is very significant because it provided strength in numbers for a group that felt itself vulnerable in the face of the rigid racial system the Americans were trying to impose. In fact, the migration did prove to be a huge setback to the project of Anglo-Americanization in Louisiana. The refugees brought with them French and Creole languages, cultures and mores and helped to re-infuse the area with racial and cultural practices that the Americans found to be abhorrent. Because of their sheer numbers, the process of Americanization slowed dramatically. Many scholars credit this migration with keeping Louisiana, and especially New Orleans, culturally distinctive long after the 1803 Louisiana Purchase (see Dessens, 2007; also Brasseaux and Conrad, 1992).

Table 1. Post-1809 Saint-Domingue refugee impact in New Orleans

\begin{tabular}{lccrr}
\hline & White & $\begin{array}{r}\text { Free people } \\
\text { of colour }\end{array}$ & Slaves & Total \\
\hline Orleans Parish (1806) & 6,311 & 2,312 & 8,378 & 17,001 \\
Refugees (1809) & 2,731 & 3,102 & 3,226 & 9,059 \\
Orleans Parish (1810) & 8,001 & 5,727 & 10,824 & 24,552 \\
\hline
\end{tabular}

Source: Lachance, 1992a: 248. Lachance got these numbers from the Mayor's Report, 18 January 1810, published in the Moniteur, 27 January 1810.

Although the process of Americanization did eventually prevail in many ways, the Americans were never completely successful in stamping out the intermediary status of free people of colour. ${ }^{3}$ Many of their descendants today identify themselves as Creoles of colour and the people I have been interviewing are very aware of their unique roots. They are aware of these roots partly because of their genealogical research, but also because of the stories passed down by family members who resisted the rigidities of

3 See Thompson, 2009 for a useful historical account of the pressures of Americanization on Creoles of colour. See Hirsch and Logsdon, 1992 for several essays that discuss various aspects of the process of Americanization in New Orleans. See Dominguez, 1986 for an account of how contemporary Creole identities looked in the 1970s. 
Jim Crow segregation by either passing into whiteness or retreating into their own Creole social circles and institutions, where they were able to live in dignity and maintain their distinctive cultural practices such as the Creole language and Catholic heritage. The following sections turn to what has been discovered during the course of this research.

\section{Methods}

Because Louisiana's regional history is so closely tied to the French-speaking Caribbean, the research has been focused on the population of Louisiana genealogists who have roots going back to colonial Saint-Domingue - an ideal population for studying the impact of regional history on racial and ethnic identities. The primary methods used have been participant observation and interviewing. Participant observation was carried out over three years, from August 2005 to the summer of 2008, with two genealogical groups: the Saint-Domingue Special Interest Group, which is mainly comprised of white Louisianians with Saint-Domingue ancestry, and LA Creole, which is a cultural and genealogical group devoted to Creoles of colour from Louisiana. I completed thirty-seven interviews.

The number of interviews was limited by several factors. The population of people from Louisiana who are actively undertaking genealogy and who know that they have ancestry going back to Saint-Domingue is relatively small in number and it is therefore somewhat challenging to find them. Although this specific population is relatively small, their experience speaks to the larger population of native Louisianians in that nearly everyone native to Louisiana is familiar with the term Creole and has some opinion of what it means in terms of race and ethnicity. It is also not uncommon in New Orleans for there to be black and white branches of a family that may or may not interact, depending on their approaches to the issue of race. Therefore, although it is difficult to find people who can actually document ties to the French Caribbean, the racial and cultural legacy of these ties is evident in the larger population of Louisiana. The number of interviews was also limited because of their labour intensive nature. Many of the recorded interviews were accompanied by a larger body of data that included the documentation of ancestral ties from Louisiana back to Saint-Domingue. While some interviewees had relatively little documentation, many others had numerous records located in archives across the city of New Orleans. For these respondents, the recorded interview was simply the top layer of a larger pyramid of data that had to be unearthed from the archives. The amount of work and data involved thus limited the target number of interviews for this study. 
In the following sections we consider how respondents use the practice of genealogy to reinforce, question or reinvent their taken-for-granted understandings of race and identity.

\section{Caribbean and Creole in New Orleans}

During the course of the interview respondents were asked to talk about their sense of racial and ethnic identification and how their genealogical research may have contributed to this. I found that many respondents had a connection to the idea of being 'Creole' - either they themselves identified as Creole or they discussed older family members who as recently as the twentieth century drew clear distinctions between Creoles and 'Américains'.

Because the term is highly politicized and often misunderstood, it is important to enter this discussion of Creole identification with a working definition of 'Creole'. Rather than trying to provide a substantive definition that would integrate all the ways 'Creole' can be used, I have developed a structural definition so that the content may differ depending on the person or group under consideration. From here on, Creole refers to an ethnic identification that allows a person to maintain a distinctive and sometimes oppositional relationship to the dominant Anglo-American culture and/ or its norm of black/white racialization. This definition applies equally well to several different ways of being Creole that will be discussed below. The very endurance of Creole identification testifies to the fact that even after generations of Americanization the Anglo-Americans were never completely successful in stamping out an alternative 'Creole' identity that was culturally distinctive and racially more complex than the system of Anglo-America. Indeed, the descendants of Saint-Domingue/Haiti in Louisiana who were part of my study have developed a variety of what I call 'Creole cultural scripts' which help them to distinguish themselves from US Americans who do not have a Creole heritage. In the course of my interviews and ethnographic work I identified four kinds of Creole cultural scripts.

White interviewees tend to adopt one of the following scripts:

$$
\text { Creole v. Américain }
$$

Creole v. the black/white racial system

Interviewees of colour tend to adopt one of the following scripts:

Creole v. African American

Creole AND African American

These choices act as 'cultural scripts' because each of them provides a 
certain way of thinking about and explaining to the self and others what it means to be Creole in the context of the overwhelmingly Anglo-American black/white racial system of the United States. In the sections below, we consider each cultural script by examining examples from the interviews that illustrate how individuals use their script to identify themselves racially and/or ethnically.

\section{Creole v. Américain}

The Creole v. Américain cultural script expresses the heart of the original struggle between the inhabitants of pre-Purchase Louisiana and the Anglo-Americans who came to take over the territory after 1803. J.E. is a good example of this form of Creole identification. ${ }^{4}$ His family has been in New Orleans for many generations. J.E. is a white, native Louisianian who was forty at the time of the interview. He is well educated and lives in an upper-middle-class New Orleans neighbourhood. J.E. is a direct descendant of Jean (James) Pitot, the first mayor of the incorporated city of New Orleans. ${ }^{5}$ It is noteworthy that although the city was officially American, its head was a French-speaking Creole.

J.E. recounts the story of his ancestor Pitot with great pride. It is clear, however, that he does not simply see this as a bit of interesting history. He understands himself and his family to be part of a long line of Creoles with a distinct history, culture and contribution to the city. When asked how he became interested in researching his family history as it relates to Saint-Domingue, here is how J.E. responded.

I'm the product of a mixed marriage. My father is a white Anglo-Saxon

Protestant and my mother is a true Creole. I mean, both of her parents come from true French New Orleans and Louisiana families. So, I spent a

4 When a respondent is referred to by two initials, those are the true initials corresponding to the real names of the respondent. Although all respondents whose initials are given consented to have their full true names used, the initials are used here to provide some measure of privacy.

5 While the city of New Orleans had existed for nearly 100 years, until its official incorporation on 17 February 1805 it was just one part of a large colonial empire under the French or the Spanish. The incorporation provided the city with a measure of independence and a charter akin to a state operating according to a constitution. It is thus significant that a French-speaking immigrant became the first mayor of the incorporated Anglo-American city of New Orleans. For more, see Pitot, 1968 and the 200th anniversary exhibit of the New Orleans Public Library, available at <http://nutrias.org/exhibits/charter/charter.htm>. 
lot of time with my maternal grandparents growing up, and they [...] had retired over to Bay St Louis, Mississippi and [...] I always had the sense of the family from them. They were both very knowledgeable about [...] their family history. And I always had a sense [...] of particular Saint-Domingue relatives, James Pitot, for example. And a gentleman by the name of Garrigues de Fleur Jacques. They were just names I knew growing up and I heard stories about them. And one reason, obviously, James Pitot was probably at the forefront is because the house is down at Bayou Saint John, so he's a pretty visible guy.

In examining the language here, one thing that immediately stands out is J.E.'s reference to himself as being the product of a 'mixed marriage'. Generally, in the twenty-first-century United States, we would tend to think of a mixed marriage as one that is racially mixed. J.E. is referring, however, to cultural mixture - a Catholic Creole married to an Anglo-American Protestant. This description of his parents' marriage as mixed indicates the sense of real difference between these two branches of his family.

The time spent with the maternal grandparents also clearly shaped his understanding of himself as Creole. The family's distinguished Creole history was also certainly a factor contributing to J.E.'s sense of being different from the dominant Anglo-American cultural tradition in the United States. He makes reference in the quotation above to 'the house' at Bayou St John. He is referring here to the Pitot House, which still stands on the Bayou and is a historic landmark that is open for public tours. ${ }^{6}$ This is the house in which James Pitot lived from 1810 to 1819 . J.E. was thus able to grow up steeped in the family's oral tradition and the visible reminder of his family's early presence in New Orleans.

Another example of the Creole v. Américain cultural script comes from L.C., an older woman, who was eighty-six at the time of our interview. L.C. lives in a beautiful condominium with an expansive view of the Mississippi River. Sitting in her living room, we were surrounded by elegant paintings portraits of distinguished ancestors. Like J.E., L.C. is also very knowledgeable about her family's history in New Orleans. She too grew up with oral family history related to the family's Creole roots. When asked how she became interested in family history research, she referred to the influence of her Tante D. and Tante Vaughn and she herself made note of the fact that she used the French word for aunt to refer to them both.

In the passage below, L.C. reflects on how she came to see that New

6 For more on the Pitot House, see Louisiana Landmarks Society <http://www. louisianalandmarks.org/>. 
Orleans was culturally unique. During the time that she describes below, she was mother to three children and the family had just moved back to New Orleans after having been away for a while.

I was so thrilled I was coming back home, you know. When we got home, Tante D. and Tante Vaughn would still talk about 'ces Américains' - [those] Americans. That was just their mindset. [...] And I guess my children were three, nine and twelve when we moved back home and [my son] came to me with eyes as big as saucers and he said, 'Mama, aren't Tante D. and Tante Vaughn Americans?' I said, 'Yes, honey.' 'Well, why do they say, "ces Américains"?' I said, 'Honey, they've never been to France.' [laughs] But that was the way they thought.

In this quotation, it is clear that the two aunts thought of themselves as fundamentally different from the Anglo-American culture they were surrounded by. From her discussion of these two women in other parts of the interview, it is clear that Tante D. and Tante Vaughn were beloved aunts with whom L.C. spent a good deal of time. In the quotation below, she reflects on how much she was shaped by the uniqueness of New Orleans history and culture without even knowing it.

Well, I didn't realize how different New Orleans was until I moved somewhere else because I was talking one day about the neutral ground. Somebody said, 'What's the neutral ground?' And I said, 'You know, on an avenue, that division between the streets.' 'Oh, you mean a median.' Well, I had never heard the word median, you know. It was the neutral ground. I thought that was the name of the thing. I didn't realize how unique that was here. And the same way with 'banket', which is a corruption of banquette. I played hopscotch on the 'banket'. I didn't know there was another word for it. I thought the sidewalk was a 'banket'. So, I had to go somewhere else to appreciate it.

The term 'neutral ground' is still used across the city of New Orleans to refer to what people in other places would call a 'median' ('central reservation' in British English). In the public memory, the term comes from the symbolic significance of the grassy area along Canal Street dividing the French Quarter from the area known as 'Uptown' - where the Americans lived. The animosity between the Creoles and the Americans was so great that from 1836 to 1852 there were three separate municipalities created to legally separate the cultural groups. The French were part of the first district in the French Quarter; the Americans were in the second district known as the Faubourg Saint Mary; and a third district was made up of a mix of French, Germans and people of mixed racial background in the Faubourg Marigny. 
L.C. absorbed many aspects of Creole cultural history and identity and at the time of the interview she described herself as 'Caucasian' and 'Louisiana French'. Her family's oral tradition includes stories about ancestors fleeing Saint-Domingue during the revolution and her time with her aunts reinforced a sense of French cultural identity. For all these reasons, L.C. is another good example of the first cultural script, Creoles v. Américains.

In the following section, we consider the experience of white interviewees who adopt Creole identification in a very different way.

\section{Creole v. The Black/White Racial System}

While the respondents discussed in the previous section have a lifelong history of Creole identification, those discussed here came to see themselves as Creole relatively late in life. Respondents in this category consider themselves Creole partly for cultural reasons, but also because they feel that traditional ways of identifying as 'white' or 'black' in the U.S. do not make sense for them. The stories discussed below deal with the aftermath of racial passing that occurred one or two generations ago.

M.R. is in his forties and grew up in Minneapolis in a white family. When his father passed away a few years ago, however, he found some papers that pointed to an unknown past. As he looked through the papers, it became clear that his father had come from a mixed-race background that he never talked about. Here is how M.R. responded to a question about how he reacted to this new information:

Well, I was stunned initially. I didn't know at the time exactly what it meant - or where it was gonna lead. But I do remember feeling - I remember feeling, uhm, pride in discovering anything about my past, because my father never talked about his father. That was [something] that never came up in my family. And my father never really was raised by his father. So I never met my grandfather. So, to find out anything - I was very proud. But also I was stunned to learn that indeed I came from a Creole past in New Orleans, and that at least at that point I understood that my great great grandfather was mixed race. He was both black and white. He was

7 Whenever reference is made to how an interviewee identified himself or herself on the interview form, it is important to know that these were purely self-identifications. There were no predetermined racial or ethnic categories to choose from on the interview form. The question read: 'With what racial and/ or ethnic groups do you identify?' Respondents filled this in with whatever they found to be appropriate for themselves. 
Creole and Afro-Creole. So, all the sudden, questions in my mind started bubbling about, well, what does that make me?

This is the kind of revelation that would take most white US Americans by surprise. Some would hide the papers away again and never mention it. M.R., however, had a very different reaction. When asked how he came to answer the question, 'What does that make me?', M.R. said,

Well, you know, I - racially - I'm white. So I appear to be white as the driven snow and I was raised white and my father was raised as white. But in understanding that my grandfather was listed on his birth certificate as colored, and his father as ' $c$ ', or colored [...] I began to realize that - there the world isn't just black and white, and that all of a sudden there was this middle ground, this Creole middle ground that had existed in Louisiana that I came out of.

It is important to note here that M.R. does not think of himself as simply bi- or multi-racial. What he does instead is to draw from Louisiana's unique racial and cultural history to find the tools to make sense of his background. There he finds a long tradition of Creoles who are racially mixed and who share a distinct cultural tradition that he has come to identify with.

Another respondent who falls into this category is P.S. She is in her sixties and grew up in Louisiana. She was raised as white, but found out just a few years ago that her family had passed as white. What is interesting in her case is that in other parts of the country P.S. would most likely be labelled a lightskinned black woman. In the context of Louisiana, however, she was able to live as white without that identification being overtly challenged. Below she talks about how she initially found out about her family's racial past.

We were at my aunt who died - at her funeral - and we were just talking about her, and then we realized that we really didn't know a whole lot about her. And we were very close. She was my godmother: I was very close to her. And so that's what, kind of. I said, 'You know, we're going to have to look into this.' [...] So, that very night, because they had a wake - they were still at the funeral home doing the wakes like they did, before - and, uhm, so we just went over to my mom and my aunt who was sitting together, and we said, 'You know, we don't really know a whole lot about ...' We called her nanan. '... my godmother.' We said, 'We don't know a whole lot about nanan.' I said, uhm, 'You know, what can you tell us about ya'll background?' And, in unison, they both said, 'Nothing. Nothing good ever came over looking into the past.'

Soon after the funeral, one of P.S.'s brothers went to the local library to 
look up their grandfather on the census. He found that the man was listed as coloured. When P.S. heard about this, she told her brother that it must be a mistake. She then went to her mother to ask her about the census record designation. To her surprise, her mother refused to talk about it. At this point, she knew something was going on. P.S. and a younger brother travelled to Pointe Coupée Parish, where her grandfather had come from, and went to the courthouse to do some more family research. What they found out was that her grandfather's family had been in Pointe Coupée since the founding of the area. Their research confirmed the mixed race ancestry in the family. P.S. reacted as follows:

So we came back home and I called my daughter who was in school [...] and she couldn't get enough. So she's the one who helped me in the beginning to do the research. [...] My grandparents were both Creoles and my mother, uhm, is Creole, but my grandparents are the ones that must have made a decision that my mother attended white schools. So that says to me that it was my grandparents' decision.

Now, several years after finding out about her family's past, P.S. is actively involved in the Creole community in New Orleans. Even though she grew up as white, in every way P.S. feels at home identifying as Creole. In contrast to M.R., she does not describe herself as racially white. Instead, on her interview sheet, she describes herself as 'Creole' with no other accompanying description. Part of the reason for this may have to do with the fact that, while M.R. grew up in the mid-West, P.S. was raised in New Orleans with traditions that she now sees in retrospect as Creole traditions. While they have very different life experiences, respondents M.R. and P.S. have in common their borrowing from cultural traditions and racial/ethnic categories unique to Louisiana. Next we consider the experience of people of African descent who identify themselves as distinct from non-Creole African Americans.

\section{Creole v. African American}

There is a long history of tension and misunderstanding between Creoles of colour in Louisiana and non-Creole African Americans. The latter often accuse the former of wanting to distance themselves from the black community, of wanting to be 'better' than black Americans. On the other side, many Creoles of colour react with frustration to these claims. They assert that there are real cultural differences between Creoles and African Americans and that it is not helpful or fair for them simply to be lumped into the larger African American category. 
V.F. grew up in New Orleans and is a Creole of colour. In the excerpt below she reflects on the experience of race and culture in her childhood.

The area where I grew up, it was 95 per cent Creole. The New Orleans neighborhoods were not segregated then. They didn't have that many black people in the city like they have now. See, nothing was segregated. You had blacks, you had Creoles and you had white. It was actually a three-class system. I mean, you've heard that before. And where I was it was 90 per cent Creole, and we had - I can honestly tell you that the block that I grew up in, they had two white families and one black family - like this was in this whole street - which you know where AP Tureaud is? OK, well it was London Avenue at the time, and we had one black family in our block, that was it. Everybody else was Creole and we had two or three white families. That was our world. This was all we knew and there was a lot of prejudice, oh Lord. [...] I was born in 1940, so we are talking all the way through the fifties. And then people started to move, but mainly the Creoles because they were tired of the segregation - ended up being in the middle. The thing came up with the black power. And, it's like, I don't really fit in with that and yet you did not fit on the white side. We had our own thing. We had our own schools, our own shows, our own - my mother says her mother used to tell her all the time because my grandfather was more brown skinned so he couldn't pass, but my mother, my grandmother and better than half of the thirteen children, but she said every time they left the house, 'Do not sit in front of that screen on the bus because I don't ever want you to be on the street and see your daddy and can't say hello to him.'

The first thing we note here is that V.F. makes a clear reference to a 'threeclass' system. Although the term 'class' may not be the best description, it is clear that there are three distinct social groups that vary by race and/or culture. When she talks about black people, she does so in a way that shows she does not consider herself to be part of that group.

She also talks about Creoles being 'in the middle' in the sense that they did not quite fit with either blacks or whites. Creoles had, and to this day in New Orleans continue to have, schools and churches that are largely composed of other Creoles. In contrast to the judgements many non-Creole African Americans make of Creoles, however, V.F.'s discussion of her father and her mother's admonition seems to indicate that V.F. was taught not to be ashamed of people who were identifiably black. When V.F.'s mother tells her not to sit 'in front of that screen', she is making reference to the segregated transportation system which compelled blacks to sit in the back of buses or streetcars. In this family there was no attempt to pass for white. Indeed, even 
those who could pass for white were counselled not to, so that they could always acknowledge darker-skinned family members.

Amelie Durant also grew up in a solidly Creole cultural context during the period of segregation. ${ }^{8}$ She was raised in New Orleans and was sixty-six at the time of the interview. In the passage below she explains how Creoles of colour distinguished between Creole and non-Creole people of African descent. The person she is referring to in the beginning of the excerpt is the man who became her husband.

I remember my aunt asking me if he cooked American or Creole and that's the distinction they made if they talked about other black people [...] that generation the way they distinguished verbally or descriptively, the way they distinguished Creole of colour from other coloured people was either they were American or they were Creole. [...] I don't think we ever thought of ourselves as African American.

Here again, as with V.F., there is a clear distinction between Creoles and non-Creole African Americans. It is interesting to note that the deciding factor in this case is style of cooking. It is also significant that the labels chosen to distinguish the two groups mirrors the labels used in the early nineteenth century - Creoles v. Américains. The distinction as Amelie describes it was not simply between Creoles and 'blacks' but rather Creoles and 'Americans'.

Although Amelie is clear about not identifying as African American, it is even more interesting to hear what she says just after this statement about how she identifies and why she does so. She explains,

I told [my friend] that more and more I consider myself more Caribbean than anything. If I am going to put the African, Afro-Caribbean [...] I really don't think of myself as American. I think it's the American part that even now I realized I think we have never considered ourselves American for some reason.

When encouraged to say more about why this is the case, Amelie says,

It's the French and Spanish. We grew up calling ourselves French and Spanish. If somebody didn't know all of our background they would assume that we were what's considered traditional Creoles, I guess. I feel this strong need, and maybe it's holding on to my family, especially since they are gone physically, it's how I can hold on to them spiritually,

8 This respondent did not consent to the use of her true name. For this reason, a pseudonym has been chosen and used here. 
mentally. It's my connection to my heritage, to my background, to hold on to them. I just don't identify with the rest of the country. Especially when you think of there was Louisiana, there was south Louisiana and New Orleans developing, all of these things happening, and then there was the rest of the country parallel. And so much of what is considered American, starting with the Independence, the thirteen states. That to me is foreign. And Louisiana is, really. I feel more of a connection to France, to the French Revolution than to this revolution. I know it's ridiculous. It's a very emotional thing.

In this response, Amelie expresses something in common with J.E. and L.C. from the section on 'Creoles v. Américains', above. The idea of being 'American' is what seems foreign to her. This cultural distinction is the reason that it is really not sufficient to think of Amelie and others like her as being bi- or multi-racial. There is much more than race or colour at issue here. The distinct regional history of Louisiana, with its strong ties to the French, the Spanish and the Caribbean, has shaped its culture in a way that has had lasting effects on its people and their ways of identifying. In the final section on the interviewees we take a look at the experience of those who identify as both African American and Creole.

\section{Creole and African American}

The respondents discussed here firmly identify as Creole, but also see themselves as being African American. The experience of L.R. helps us to understand why many of them have come to this way of thinking.

Now I'm very comfortable with the label 'Creole'. In the 60s, I was not. I fought against it. I thought it meant a pride in being light skinned and privileged because it had no historical connection. I had no source - no academic source - to clearly define what it meant in cultural terms. [...] My mom had a sixth grade education; my dad got his GED from high school. And they were taught that they were Creole and that they were separate and they tended to live apart. They tended to co-marry, co-mingle or intermarry with others of that culture. And so I didn't like the prejudice that I saw. [...] So I was bitter and very confused.

As she looked at the social and racial landscape of the 1960s, L.R. just could not reconcile the prejudice she saw among Creoles of colour with her own sense of what was right. The experience she describes, the way her family reacted to non-Creole blacks, reflects exactly the kinds of criticisms many African-Americans in New Orleans have of Creoles. As L.R. explains here, 
there are indeed some Creoles who see themselves not only as different but as better than non-Creole African Americans. There are many others, however, who do not make this kind of judgement.

Below, L.R. describes how she reacted to the way she was raised.

I believed that I had to show my black ethnicity through my dress and my hair and that's when I stopped using permanents and straightening my hair and began to use [...] wore an afro [...] all through graduate school. So I think I went around the block to get across the street. Now I'm comfortable.

Now, nearly fifty years later, L.R. identifies with both groups. On her interview sheet she wrote that she identifies as African American, with no other racial or ethnic descriptor included. Throughout the interview, however, she makes clear that she also sees herself as Creole.

There are many others as well who see themselves as equally African American and Creole. I encountered several of them in 2004, during the early part of the fieldwork for this project, when I monitored an email discussion group called the Cajun/Creole List. Much of the conversation on that list dealt with the issue of how to reconcile being 'black' and 'Creole'. ' Many writers expressed their identification with both groups.

Outside of Louisiana, native-born blacks of non-immigrant parents generally have one choice in how to identify. Because they cannot point to their families having recently come from another country they are automatically categorized as African American in the Anglo-American cultural tradition. This last cultural script allows Creoles in this group to choose a more nuanced cultural and ethnic identity, one that draws on the multiple cultural and linguistic threads that have helped to create the United States.

\section{Conclusions}

The stories we have examined here make it clear that we must pay closer attention to regional history when focusing on issues of race and identification in the United States. Although there is certainly a dominant black/

9 This work was part of preliminary field work that helped me to gain access to some of the diverse people and points of view in the Louisiana Creole community. I sent out a survey to which 23 people responded. Although the total number of responses was low, there was some interesting variety in responses to the question of how people identified themselves. As with the current project, people were allowed to self-identify. Out of the 23 who sent back a survey, 7 identified as both black and Creole, 5 as black, and only 1 as Creole with no other accompanying descriptor. 
white framework for thinking about and organizing race in the United States, the reality is that the racial and ethnic landscapes in many regions of the United States have been shaped by social and cultural processes that are much more complicated. We have seen here how past migrations from Saint-Domingue/Haiti to Louisiana significantly slowed the process of Anglo-Americanization. The endurance of various forms of Creole identification as reviewed in the sections above testify to the ongoing resistance a subgroup of Louisianians have to the dominant black/white system of racial classification. But Louisiana is not the only place where unique regional histories have helped to shape understandings of race and ethnicity that differ from the dominant US model. We would also find the importance of regional history when looking at the history of migrations and cultural exchanges between South Florida and the Caribbean, between other parts of the Gulf South and the Caribbean, and between parts of the southwest and Mexico. The intricate ways these southern regions have been tied to different parts of Latin America and the Caribbean call for an expanded understanding of what it means to be 'American' in the United States.

\section{Works Cited}

Ball, E. 1998. Slaves in the Family. New York: Farrar, Strauss, Giroux.

Brasseaux, Carl A., and Glenn R. Conrad (eds). 1992. The Road to Louisiana: The Saint-Domingue Refugees, 1792-1809. Lafayette: Center for Louisiana Studies.

Dessens, Nathalie. 2007. From Saint-Domingue to New Orleans: Migration and Influences. Gainesville: University Press of Florida.

Dominguez, Virginia R. 1986. White By Definition: Social Classification in Creole Louisiana. New Brunswick, NJ: Rutgers University Press.

Foner, Laura. 1970. 'The Free People of Color in Louisiana and St Domingue: A Comparative Portrait of Two Three-caste Slave Societies'. Journal of Social History 3.4: 406-30.

Hall, J. D. 1998. “You Must Remember This”: Autobiography as Social Critique'. Journal of American History 85.2: 439-65.

Hangar, Kimberley S. 1997. Bounded Lives, Bounded Places: Free Black Society in Colonial New Orleans, 1769-1803. Durham, NC and London: Duke University Press.

Hareven, T. K. 1978. 'The Search for Generational Memory: Tribal Rites in Industrial Society'. Daedalus 107.4: 137-49.

Haskins, James. 1975. The Creoles of Color of New Orleans. With drawings by Don Miller. New York: Thomas Y. Crowell.

Hirsch, Arnold R., and Joseph Logsdon (eds). 1992. Creole New Orleans: Race and Americanization. Baton Rouge: Louisiana State University Press. 
Johnson, Jerah. 1995. 'Congo Square in New Orleans'. Samuel Wilson, Jr. Publications Fund of the Louisiana Landmarks Society. Originally published (1991) as 'New Orleans's Congo Square: An Urban Setting for Early Afro-American Culture Formation'. Louisiana History: The Journal of the Louisiana Historical Association 32.2: 117-57.

Lachance, Paul F. 1992a. 'The 1809 Immigration of Saint-Domingue Refugees to New Orleans: Reception, Integration, and Impact'. In Carl A. Brasseaux and Glenn R. Conrad (eds). 1992. The Road to Louisiana: The Saint-Domingue Refugees, 1792-1809. Lafayette: Center for Louisiana Studies: 245-84.

-. 1992b. 'The Foreign French'. In Arnold R. Hirsch and Joseph Logsdon (eds), Creole New Orleans: Race and Americanization. Baton Rouge: Louisiana State University Press: 101-30.

Martin, Joan. 2000. 'Plaçage and the Louisiana gens de couleur libres: How Race and Sex Defined the Lifestyles of Free Women of Color'. In Sybil Kein (ed.), Creole: The History and Legacy of Louisiana's Free People of Color. Baton Rouge: Louisiana University Press.

Pitot, Henry Clement. 1968. James Pitot: A Documentary Study. New Orleans, LA: Bacage.

Thompson, Shirley E. 2009. Exiles at Home: The Struggle to Become American in Creole New Orleans. Cambridge, MA: Harvard University Press.

Tregle Jr., Joseph G. 'Creoles and Americans'. In Arnold R. Hirsch and Joseph Logsdon (eds), Creole New Orleans: Race and Americanization. Baton Rouge: Louisiana State University Press: 131-85.

Tyler, K. 2005. The Genealogical Imagination: The Inheritance of Interracial Identities. Sociological Review 53.3: 476-94. 


\title{
Creolizing Barack Obama
}

\author{
Valérie Loichot
}

La créolisation diffracte quand le métissage appauvrit.

Édouard Glissant, 'Métissage et créolisation', p. 50

[Creolization diffracts while métissage flattens $]^{1}$

While the French, during Barack Obama's presidential campaign, overwhelmingly responded in a survey that they would be willing to elect a black president, the French language paradoxically does not have a proper epithet to name the American president. ${ }^{2}$ On 4 June 2008, Figaro journalist Pierre Rousselin described the then winner of the Democratic nomination as 'a 46-year-old métis'. Métis, a word embedded in the French history of slavery and colonialism, and today synonymous with either denigration or praise of racial and cultural mixing, has acted as Obama's default epithet in the French mainstream media. Through a reflection on the naming of the American president in French newspapers and in political or theoretical writings from Metropolitan France and from the French Overseas Department of Martinique - this chapter's main concern is to illuminate the discrepancies between racial perceptions and constructions in continental France and in Martinique. While the Metropolitan French media favour the epithet métis, Martinicans privilege the process of creolization to attempt to describe the

\footnotetext{
1 All translations are mine unless otherwise noted.

2 To the Figaro (2008) survey, 'Seriez-vous prêts à voter pour un président noir en France?', 61.3 per cent of the 25,120 respondents replied that they would.
} 
figure of Obama. The representation of Obama, then, functions as a helpful medium to reflect on contemporary racial and cultural constructions that do not travel well.

Obama as a symbol represents a particularly compelling example of the untranslatability of race since, as the new head of state of a powerful Western Nation, and as an immediately recognizable figure in global consciousness, he cannot be dismissed as a negligible exception. ${ }^{3}$ The notions of métissage - which attempts to stabilize race - and creolization - which destabilizes racial constructs - will guide us through our analysis of the naming and misnaming of Obama in Metropolitan France and in Martinique. My choice of the case of the French-Caribbean island of Martinique is particularly important in understanding the impact of the election of Obama on the collective psyche of a people predominantly issued from the Black Diaspora, located in the Americas, yet still part and parcel of France and of the European Union. The sense of influence between Martinique and Obama goes in both directions. Martinican creolization theory destabilizes the assignation of a fixed racial identity to the American president while Obama as a symbol links Martinican Creole consciousness to a worldwide redefinition of the dynamics between power and race.

\section{The Trap of Métissage}

The Figaro quotation cited above defining Obama as métis illustrates the essentialism to which Obama has been subjected in the French press. He is first and foremost defined by his race, not by his abilities to govern. The description, 'a 46-year-old métis', encompassing age and racial categorization, strangely echoes nineteenth-century bills of sale of enslaved humans. The word métis deserves special attention since it holds no equivalent in the English language, or in the American racial, legal or historical contexts. In the 1967 edition of Harrap's Dictionary, métis is translated as 'half-breed', 'cross-bred' or 'mongrel (dog)'. A 'plante métisse' is a 'hybrid plant'. In the 2007 edition, the definition hasn't changed much, since métis is still translated as 'half-caste' or 'half-breed'. Clearly inscribed in the discourse on race as a manifestation of biological hybridity, the word métis therefore shocks because it is derived from the basic colonial assumption that races are biologically discrete entities. ${ }^{4}$

3 The métis has been historically and legally treated as an aberration, an accident. See Kandé, 1999: 13-34 (Introduction).

4 On the temporal and discursive coincidence between the appearance of the word métis and the invention of racial categories, see Kandé, 1999: 13-14. 
On the level of historical accuracy, the use of the term métissage is also misleading, since it does not have an exact equivalent in the US context. While it resembles the term 'miscegenation', and can sometimes be synonymous with it, the two terms are grounded in different legal practices. Métissage and miscegenation historically differ since the 1685 Code noir comprised a third category of métis born of the union of unmarried free men with enslaved women. The slave and her children, should, according to the letter of the law, be legitimized and emancipated. ${ }^{5}$ In contrast, the US 'One-Drop Rule' allowed for only two categories (Davis, 1991: 4-6). In this absolute black-and-white binary system, métissage disappeared into the 'black' category. The use of métis by the French therefore appears as the projection of a category of thinking foreign to the US context. ${ }^{6}$ Commenting on the use by the French media of words such as métis, at best, or at worst, mulâtre ('mulatto'), to define Obama, American commentator on French politics Arthur Goldhammer sharply warns his readers that: 'words denoting mixed racial origins such as "mulatto," "octaroon," [sic] and "high-yellow" can still be found in Faulkner but have dropped out of everyday American use' (Goldhammer, 2008).?

However, most French journalists bracket out the racialist history and connotations of the word métis. Obama's métissage is often presented as a form of enthusiastic praise of cultural mixing. Philippe Boulet-Gercourt, US correspondent for Le Nouvel Observateur, introduces Obama's success and charisma with three epithets: 'Youth, Idealism, and Métissage' (BouletGercourt, 2008). In this use of métissage as the ultimate example of multicultural success, the racialist origin of the term is banished to oblivion.

5 See Chesnais 1998: article 9. The marriage between free and enslaved will be rendered illegal in the 1724 rewriting of the black code.

6 As Goldhammer points out on his blog: 'French speakers should refrain from describing anyone in English as a "half-breed" or product of "miscegenation" unless they mean to be offensive' (Goldhammer, 2008). Moreover, Obama himself escapes this model of American miscegenation since his mixed double heritage is a result of a postslavery encounter, resulting from immigration. According to Marcus Mabry, Obama has been described as 'postracial' and thus less threatening than a descendant of American slavery: 'His story is, in part, an immigrant's story, devoid of the particular wounds that descendants of American slavery carry' (Mabry, 2008). For Mabry, this specific 'postracial' mixing allows whites to see Obama as 'not too black' to be electable, but also 'not black enough' for some African Americans who consider that his cultural and historical difference does not represent them fully.

7 Goldhammer's comments as well as the postings on his blog provide a good illustration of the issue of positioning Obama racially in France. 
Métis, while deeply rooted in a racialist categorization of humanity, also paradoxically allows one to imagine a simplifying multiculturalism in which difference has ceased to function under the guise of a blind idealism. Indeed, métissage often functions in the media as an unproblematic celebration of difference masking cultural differences and violence (see Amselle, 1999: 35). This sort of multiculturalism, for Kwame Anthony Appiah, seems to 'encompass everything and nothing [...] and designates the disease it purports to cure' (Appiah 2006: xiii). This is precisely the danger of métissage: proclaiming the illusory victory of sameness, while using a word rooted in racialist thinking.

Eighteenth- and nineteenth-century categories of thought tend not to shock the French public, and are used by even the most progressive journalists and writers. For the French, Obama is a 'safe black', or rather a 'safe métis', because he is the exception and his category is fixed ... which makes us wonder who the French readers of the Figaro had in mind when 61 per cent of them responded that they would be ready to elect a black president. ${ }^{8}$

One could argue back that the French embracing of Obama's métissage is good willed and has had positive effects. And, indeed, it has. From blogs showing their support to Obama, to organized political initiatives, France was struck by 'Obamamania'. From the trivial to the serious, from political activism to erotic desire, Obama compelled the French. 'Get out the vote' French initiatives, for instance, brought Americans living in France to cast their ballot in overwhelming numbers. However, we should be suspicious of that love, as long as it remains linked to a fascination for métissage. As Françoise Vergès has shown, in her monumental Monsters and Revolutionaries, the fascination and love for métissage is just the other side of the coin of its denigration. Métissage, Vergès contends, 'contain[s] at heart an ambiguity [...] that to some anticolonialists offered a radical challenge to the process of mono-identification and European racism, and to others meant the disappearance and the lapse of memory' (Vergès 1999: 8-9).

Métissage in the French imaginary thus represents love and hate, fear and desire, lust and disgust. The 'métis' Obama clearly falls on the side of love, often erotic love: KikiBird, a French blogger, asks, 'Why do French women love Obama?' inviting her readers to 'bring sexy back to the White House!' (KikiBird 2008). Obama's erotic appeal is clearly linked to his perceived racial inheritance. Referring to Obama's appearance on television in the

8 Obama's US citizenship and culture also make him more acceptable to the eyes of the French than a man of West-African background. On the 'décalage' or gradation between the perception of black Americans and black Africans in France, see Edwards, 2003: 11-14. 
Ellen DeGeneres Show, KikiBird comments: 'I think he got his dancing skills from his mom's side of the gene pool, but it's soooooooo cute!' (ibid.). Far from claiming that the French who use the word métis to define Obama commit acts of conscious racism, I want to argue that the French language itself fails to seize a figure that escapes quick racial, cultural and historical categories, and that the person of Obama provokes - or should provoke - a paradigmatic shift in our perception and representation of humanity beyond racial categories.

The alternative description of Obama to the word métis is the use of the adjective noir. The black community in France, for whom Obama sparks a 'new black consciousness', according to a June 2008 New York Times article, enthusiastically adopts the term. However, the term 'noir' is as problematic in France as it is in the United States. Literary scholar Louis Chude-Sokei (2007) argues that the 'all-consuming category of "black" misclassifies Obama, who complicates both the black and white divide and the definition of African American.

Significantly, French journalists extremely rarely use the term 'Africain Américain' to describe Obama. A systematic word search in Le Monde revealed that Obama was called 'Africain Américain' in a grand total of four articles from January to June 2008. The French media are not generally resistant to using English words such as 'blogger', 'sniper' or even 'les Blacks'. So, why this dismissal of the term 'Africain Américain'? The French, from the 1789 Déclaration des droits de l'homme et du citoyen to the 1905 Loi de laïcité, two founding legal documents when it comes to the invisibility of race in France, take the separation between citizenship and religious, gender and ethnic specificities seriously. Under a blanket Republicanism, originally implemented to protect individual differences, a French person is only a citizen: not a woman, not a man, not a Muslim, not an Antillean woman. ${ }^{9}$

The term 'Africain Américain' violates the rule of Republicanism precisely because it combines citizenship with cultural or ethnic difference. Translated into a French context, Obama's African Americanness is simply invisible. The hyphenated term 'Français-nord-africains' is equally unthinkable. However, the daily experience of discrimination of 'visible minorities' persistently contradicts the spirit of the Republic. In media representation and

9 Hence the illegality in France - something surprising to Americans used to checking their ethnic box - of polling citizens and migrants about race, citizenship, ethnic and religious background, which prevents affirmative action, or, as the French cynically call it, 'positive discrimination'. This law of invisibility is sacrosanct in France, a matter of French pride that can mask an unwillingness to recognize discrimination. 
stereotypes, in police harassment, in workplace inequities, visible minorities, sometimes French for three and even four generations, sometimes for more than a century, remain highly visible second-class citizens to the so-called 'Français de souche' or 'pure French' (see, e.g., Hargreaves, 2007 [1995] and Rosello, 1998: 1-20).

To summarize, métissage fails to translate Obama's mixed identity and the term 'African American' escapes French categories of thought. If the term 'African American' succeeds in classifying Obama within US census categories, it is nonetheless insufficient to grasp Obama's cultural complexity. By examining the treatment of Obama in Martinique, the next two sections shift the focus from the failure to classify Obama biologically or racially to the more promising gesture of defining him culturally through the lens of creolization theory.

\section{Obama as a Martinican Creole?}

A detour through the French Overseas Department of Martinique and through Martinican thinker Édouard Glissant's notion of creolization helps us to name Obama within the French language, and even perhaps on a global level that would transcend national, linguistic and ethnic boundaries. While Malian cultural theorist Manthia Diawara has called Obama the 'président des terriens' [president of all humans] (Diawara 2008), and while Obama encountered an unprecedented worldwide scream of enthusiasm immediately following his election, he seems to have been particularly readily assimilated within Martinique's cultural and political realms.

One could even say that Obama has been Martinicanized. His name and image have been incorporated into the country's commercial and cultural landscape. His first name, homonymous with baraque or 'shack', was used to name, for instance, a restaurant shack on the beach at Sainte-Luce (Fig. 1). There is a Martinican Obama fan club on Facebook, which uses the creolized slogan 'yes nou ni canne!' and sugar cane stalks as its profile image since 'can' is homonymous with canne, or 'sugar cane'. A street in the town of Le Diamant has been named after the American president (Fig. 2). ${ }^{10}$ Of symbolic importance is also the fact that Glissant elected Le Diamant as his Martinican residence, and that the town has become an important memory site with the edification of a monument - fifteen massive human figures

10 'The newly dubbed Rue Obama extends from the heart of the picturesque city of Le Diamant, located along the island's pristine southern coast, to the sea. Fittingly, the street measures 144 meters for the 44th President of the United States.' See HighBeam Research, 2009. 


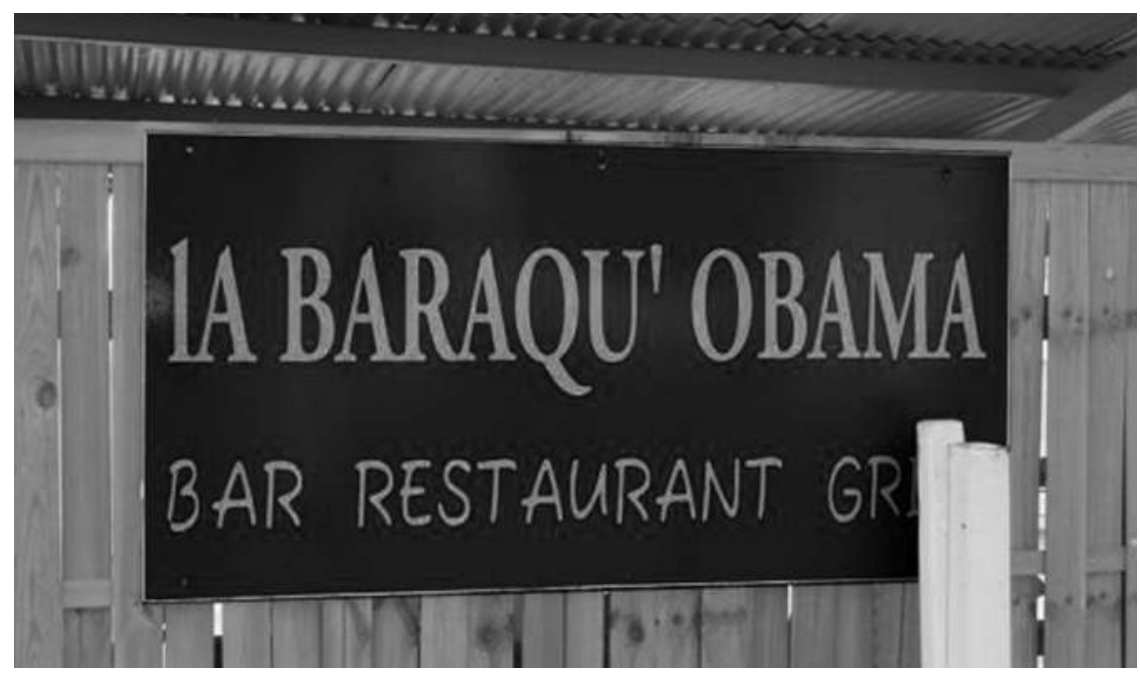

Fig. 1. La Baraqu' Obama, Sainte-Luce, Martinique.

Fig. 2. Rue Barack Obama, Le Diamant, Martinique.

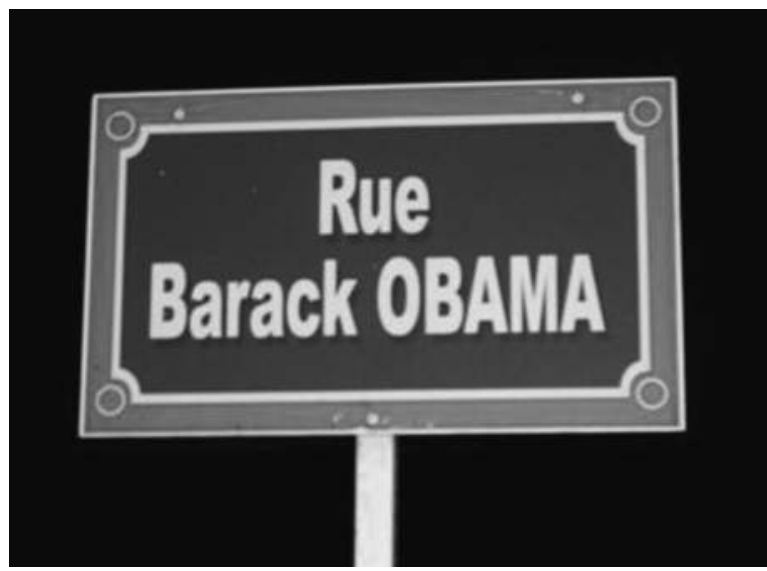

facing the sea, sculpted by Martinican artist Laurent Valère to the memory of the drowned victims of an 1830 slaveship wreck (Fig. 3). ${ }^{11}$ The choice of Le Diamant for the naming of the 'Rue Barack Obama' is thus highly significant because it inscribes Obama's name in the continuum of a landscape memorializing the Martinican Diasporic memory, in a gesture similar to Glissant's vision of Obama as 'son of the abyss', which I analyse below.

11 As J. Michael Dash has shown, the Diamond Rock, located in Le Diamant, is central to Glissantian imaginary (Dash, 2004: 94-109). 


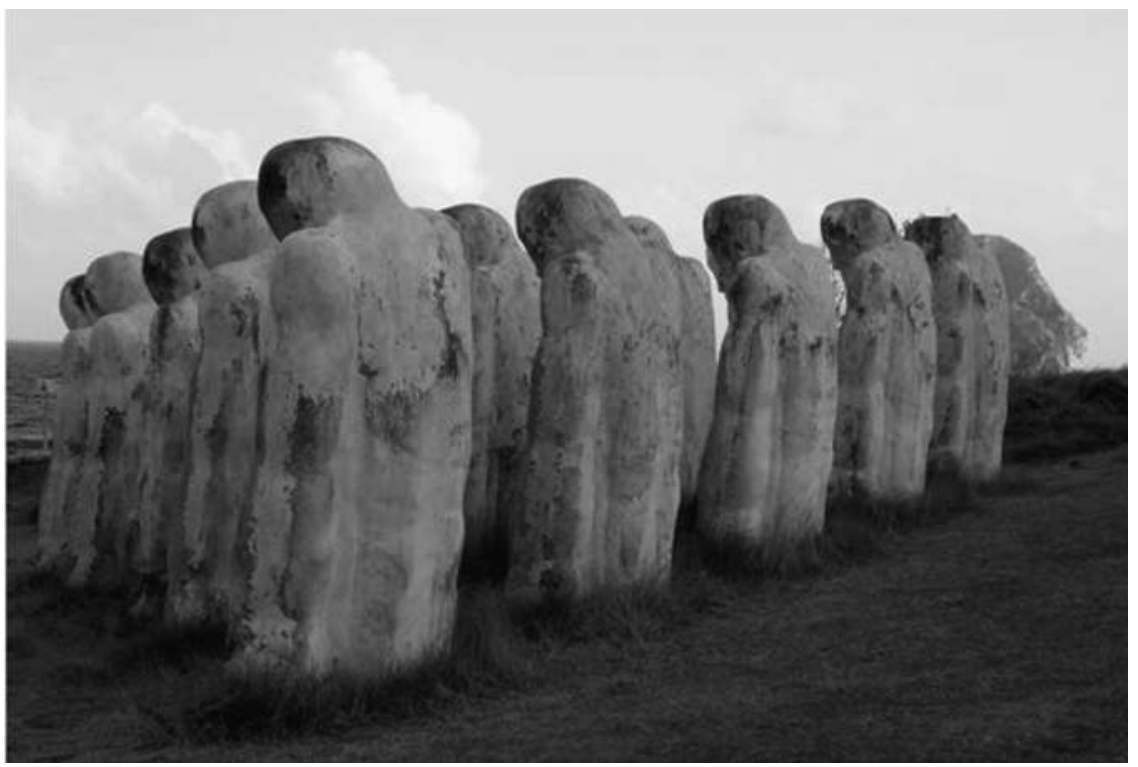

Fig. 3. Laurent Valère's Memorial, Anse Cafard, with Diamond Rock in the background. Le Diamant, Martinique.

In this wealth of integration of Obama into the physical and cultural landscape of Martinique, the video 'Obama martiniquais' (2009) created by the local group S-CREWW Productions, and available on YouTube, stands out. The video dubs one of Obama's campaign speeches in French and in Martinican Creole. 'Martinican Obama' begins his speech with a confession: 'Je n'ai jamais été ni un Américain, ni un Hawaien, en réalité, moin cé un Matinikè' [I was never an American nor a Hawaiian, in fact, I am a Martinican]. Notable is the fact that Hawaii and Martinique are presented as nations on the same level as the United States. ${ }^{12}$ In a parallel nationalist move, Martinican Obama switches from French to Creole as soon as he proclaims his Martinican citizenship. The election of a black man from Hawaii has certainly helped to fuel, at least symbolically if not politically, the recent strikes and protests in Martinique and Guadeloupe for more autonomy from the French government. ${ }^{13}$

12 Obama's birth and early upbringing in Hawaii creates yet another link with Martinicans. The 50th American State occupies a political position similar to the French Overseas Department.

13 Important to note is the temporal proximity of the election of the American president with the generalized strikes in Martinique and Guadeloupe. From 
In the aforementioned video, not only does Obama acquire Martinican Creole speech but soon after evoking his Martinican citizenship in Creole, he lists, as proof of the authenticity of his belonging to Martinique, a selection of his favourite things to eat, which include 'dachine' (dasheen or taro root), 'pois d'angole' (Congo peas) and 'queue d'cochon' (pig tails). Obama does not ingest just any type of Martinican food, but, specifically, ingredients strongly tied to the memory of survival under slavery, to root vegetables linked to the earth and to African ingredients. Obama is not only assimilated to Martinican identity, but also assimilates it, through eating and speaking Creole. The strong association between Creole language and Creole food is particularly significant in the Martinican context. As Celia Britton demonstrated in her essay 'Eating Their Words', literary critics tend to describe the language of Martinican and other Caribbean writers by a profusion of culinary metaphors (Britton, 1996: 15-23). For European critics, Caribbean novelists write a peppery, vanilla-scented and spicy language. In short, 'in the European imagination, the Caribbean has always been associated with things that you put in your mouth' (ibid.: 15). Britton compellingly argues that the literal consumption of the Caribbean by Europeans who ingest its 'rum, coffee, tobacco, coconuts, fruit, etc.' (ibid.) goes hand in hand with the metaphorical treatment of Caribbean novels and Caribbean language as palatable products. In the occurrence of Obama speaking Creole language as he utters the name of Creole dishes, however, we seem to be faced with a different type of encounter. The association of food and language, in this particular example, is not a case of exotic reduction of Creole language to Creole food, but, rather, a case in which language and food contribute to the construction of a complex, creolized self. The food items listed are not the typical tropical dishes of the touristic vision such as bananas, coconuts and spice. Instead, the vegetables, tubers and salt meat are loaded with a historical

December 2008 to February 2009 Guadeloupeans and Martinicans were in upheaval against the high cost of living and demanded more autonomy. The protests included marches of more than 100,000 people at a time. The people were united under the leadership of the autonomist organization LKP (Lyannaj Kont Pwofitasyon, or Union Against Profit), led by figures such as Guadeloupean unionist Elie Domota. The strikes, which were anti-imperialist and autonomist in nature, could not of course have been inspired by American politics. For a chronicle of the strikes in Martinique and for a summary of the movement's ideology, see Nemo, 2009. However, the symbolic power of the election of a black man as president of the United States was undeniably energizing. For a discussion of the adoption of the Obama campaign iconography by Caribbean protestors, see Bonilla, 2010. 
African-Caribbean tradition of resistance (see further my article 'Between Breadfruit and Masala: Food Politics in Glissant's Martinique': Loichot, 2007: 124-37). Additionally, the association of 'Martinican Obama' with food is not a unilateral movement of assimilation whereby the historical figure would be turned into a palatable food item. Instead, 'Martinican Obama' assimilates food and projects it back into a linguistic form in an interactional movement. In this particular case, then, food acts not as a mode of impoverishing assimilation, but as a form of interactive cultural creolization.

The widespread acclaim for Obama in Martinique, however, is not unanimous. Obama's skin, and the history it carries, is not an automatic passport that he could wave to claim an automatic right to Martinican and Creole identity. Martinican writer Raphaël Confiant, for instance, is one of the most virulent detractors of the assimilation of Obama into Martinican culture. In an essay published online after the death of Michael Jackson, 'Pitié pour Michael Jackson', Confiant (2009) laments the symbolic violence experienced in the United States and in the world by imposed European standards of beauty. He presents Jackson as a victim of this symbolic violence, which led him deeply to alter his skin and facial bone structure to conform to European norms of beauty. So far, Confiant's criticism seems fair. However, things start to spoil when he uses the example of Barack Obama as one of the perpetrators of this white symbolic violence imposed on African Americans such as Michael Jackson, contrasting the 'white' president of the United States with the 'black' president of South Africa: 'Pourquoi le chrétien monogame habillé à l'occidentale Obama qui parle un anglais raffiné ("West Coast") nous plaît tant alors que l'animiste polygame vêtu de peau de bête lors des danses tribales et qui ne craint pas de s'exprimer en zoulou Jacob Zuma (président de l'Afrique du Sud) hérisse beaucoup d'entre nous?' [Why does the Christian monogamous Western-dressed Obama who speaks a refined ('West Coast') English so please us while the animistic polygamist clad in animal skin in the tribal dances and who is not afraid to speak Zulu, Jacob Zuma (president of South Africa), irritates many of us?] (Confiant, 2009). Leaving Confiant's rather stereotypical description of the South-African president aside, I will concentrate on his depiction of the American president. For Confiant, Obama's clothing, religion or linguistic orthodoxy strip him of his colour, as if clothing or language could substitute for the visibility of skin, and for the past history and present experience of violence that 'overdetermines' it, to use a Fanonian term (Fanon, 1952: 93).

In his memoirs, Obama addresses at great length what Martinican psychiatrist Frantz Fanon would have called the 'overdetermination' of his skin 'from the outside' (Obama, 2004 [1995]). He describes the long evenings spent reading writers of the Harlem Renaissance as well as Fanon 
himself. More specifically, Obama identifies the foundational moment in which the weight of the colour of his skin hit him frontally, so to speak. While in Indonesia, the child then called Barry was leafing through a daily newspaper when he saw the picture of a man with 'crinkly hair, heavy lips, and broad, fleshy nose, all had this same uneven ghostly hue [...] he must be terribly sick [...] A radiation victim, I thought' (ibid.: 30). After turning the page and reading the whole story, Barry realized that the disfigurement was due to an excessive use of chemical skin whiteners. Obama confessed the physical effect of the realization of the negativity of blackness on his own body, feverish and silenced: 'I felt my face and neck get hot [...] I had no voice for my newfound fear' (ibid.: 30). The event is quickly followed by a Fanonian moment of reassessing Barry's favourite television shows, and of seeing for the first time that 'Cosby never got the girl on I Spy, that the black man on Mission Impossible spent all his time underground' (ibid.: 30; emphasis mine). In this episode Obama is much closer to the black man in the Fanonian cinema than to a commercial-advertising white criterion of beauty: 'Impossible d'aller au cinéma sans me rencontrer', writes Fanon. 'À l'entracte, juste avant le film, je m'attends. Ceux qui sont devant moi me regardent, m'épient, m'attendent. Un nègre-groom va apparaître. Le cœur me tourne la tête' [I can't go to the movies without meeting myself [...] During the break, right before the movie, I expect myself. The people in front of me look at me, spy on me, expect me. A negro-boy will soon appear. My heart makes my head spin] (Fanon, 1952: 113). Obama's and Fanon's experiences of their exteriorized vilified skin, as well as the deep physical discomfort that ensues, are strikingly similar. This epidermalization, to use a Fanonian term, is in itself enough to link Obama to the African Diasporic community as a whole, even if his personal history differs from that of the descendants of deported African slaves.

In 2008, on his website Montray Kreyol, Confiant, along with his editorial team, had described the then presidential candidate as 'un yankee noir. Un Black anglo-saxon protestant aucunement différent, hormis le bronzage, de son compatriote McCain' [a black Yankee. A black protestant Anglo-Saxon in no way different from his compatriot McCain, save for the tan]. While the editorial team's criticism of Obama as a political figure - and of the American imperialism he represents - can be quite justified, it is nonetheless surprising that they strip him of his racial identity. By the reference to his 'tan', Confiant and his team sever Obama from his belonging to a history of racialized America, in a way reminiscent of Italian Prime Minister Silvio Berlusconi, who had described Obama as 'young, handsome, and tanned' (Berlusconi, 2008). The same stroke strips him of his skin and of his history. Even though Obama, as he admitted himself in Dreams From My Father, 
was not socially, culturally, economically like African Americans linked to an inherited history of Diaspora and slavery, he was nonetheless legally and culturally positioned as black. The birth of a child of multiracial parents like Obama was still a crime in 1961. In 1967, anti-miscegenation laws were still enforced in seventeen Southern states (all the former slave states plus Oklahoma), as American poet Natasha Trethewey reminds us poignantly: 'I return / to Mississippi, state that made me a crime' (Trethewey, 2006: 46). More attuned to the political and legal American context than Confiant and his editorial team, Patrick Chamoiseau and Édouard Glissant insist that Obama is 'un Noir, métissé de blanc mais les critères disent que la plus infime goutte de sang noir fait ici de vous un noir à part entière' [a Black man, mitigated with white, but the criteria speak loud and clear: here, the most infinitesimal drop of black blood turns you into a full-blooded black] (Chamoiseau and Glissant, 2009: 7).

\section{Creolizing Barack: A Mutating World}

On the other end of the Martinican intellectual spectrum from Confiant, and contrary to Confiant's depiction in which Obama's racial significance disappears under his cultural and political allegiance to a capitalist power, Chamoiseau and Glissant, in L'Intraitable beauté du monde: adresse à Barack Obama (2009), wrote in praise of the American president. For Chamoiseau and Glissant, Obama's creolized self comes to represent a community - that of the descendants of the African Diaspora - to which he does not belong by inheritance but rather by stance and choice. Obama not only becomes assimilated to a Martinican Diasporic identity, but also acts as one of its main constructive agents.

Chamoiseau and Glissant call Obama 'l'homme de la créolisation' [the man of creolization] (Chamoiseau and Glissant, 2009) because he embodies the process of creolization through his complex cultural, familial and racial diversity impossible to fix in one static definition. Obama is an agent of creolization, let us insist, not the representative of métissage. Glissant is careful to distinguish between métissage and créolisation: 'La créolisation diffracte quand le métissage appauvrit [...] Bref, [la créolisation est] un métissage, mais avec une résultante qui va plus loin et qui est imprévisible' [creolization diffracts while métissage flattens [...] In short, [creolization is] a form of métissage, but with a result that goes further and that is unpredictable] (1999: 50). For Glissant, while métissage is calculable and stifling, creolization is an unpredictable dynamic process, which leads to openness rather than fixity. Moreover, while métissage is rooted in a biological discourse assuming discrete and predictable categories of race, 
creolization, based on a cultural and linguistic model, escapes the rules of Mendel's genetics: 'On peut calculer les effets d'un métissage de plantes par boutures ou d'animaux par croisements. On peut calculer que des pois rouges et des pois blancs mélangés par greffe donneront à telle génération ceci, à telle génération cela. Mais la créolisation, c'est le métissage avec une valeur ajoutée qui est l'imprévisibilité' [The effects of métissage of plants by grafting or animals by crossing can be measured. The result of grafting of red beans with white beans can be calculated in that they will result in such and such a way in various generations. But creolization is métissage with the added value of unpredictability] (Glissant, 1996: 18-19). In his March 2008 speech on race Obama describes his family history as what could be a textbook example of Glissant's creolization:

I am the son of a black man from Kenya and a white woman from Kansas. I was raised with the help of a white grandfather who survived a Depression to serve in Patton's Army during World War II and a white grandmother who worked on a bomber assembly line [...] I've gone to some of the best schools in America and lived in one of the world's poorest nations. I am married to a black American who carries within her the blood of slaves and slaveowners - an inheritance we pass on to our two precious daughters. I have brothers, sisters, nieces, nephews, uncles and cousins, of every race and every hue, scattered across three continents [...] it is a story that has seared into my genetic makeup the idea that this nation is more than the sum of its parts - that out of many, we are truly one. (Obama, 2008)

Obama's final sentence is an almost word-for-word echo of Glissant's definition of creolization: 'la créolisation, c'est bien le métissage des cultures avec une résultante qui va plus loin que les données d'origine' [creolization is indeed cultural métissage, whose result goes beyond the sum of its parts] (Glissant: 1999, 50). Moreover, Obama's self-portrait welcomes unlimited categories: black, white, augmented and complicated by the determinants 'of every race and every hue'. He is black, white, American, Kenyan, Indonesian, Hawaiian, African American, by inheritance, marriage, location, culture and choice. His body stretches out from the wealthiest to the poorest, from the patriotic to the cosmopolitan, from the foreigner to the native, from the wounds of slavery to the preciousness of two daughters, creolizing ad infinitum. 'I am married to a black American who carries within her the blood of slaves and slaveowners - an inheritance we pass on to our two precious daughters'. The 'we' of the previous sentence consolidates around the shared history of slavery, passed on not from parents to child, through the vertical inheritance of 'filiation', as Glissant would have it, but rather through what he would call the horizontal movement of expanse or Relation, through his union with his 
wife Michelle and through the relationship of his wife and daughters to the inheritance of slavery (see ibid.: 59-75).

Also, he relates to the African American community through work, by choosing to become an 'active relay' in the struggle for equal rights: 'Obama est un créole étasunien ayant choisi de participer à la communauté noire américaine' [Obama is a United States Creole who chose to take part in the African American community] (Chamoiseau and Glissant, 2009: 70). In this, as well, Obama performs Relation. This is perhaps why Glissant surprisingly addresses president Obama in the following terms: 'Et vous voilà, vous, fils du gouffre' [And there you are, son of the abyss] (Glissant, 2009: 5). As we know, Glissant associates the gouffre or the abyss with the unfathomable wounds of slavery left on the bottom of the ocean and of the imaginary (see Glissant, 1990: 17-21). Glissant and Chamoiseau remind us of this meaning of the abyss in their letter to President Obama: 'Or la rumeur a quitté les fonds [marins], et à travers vous, monsieur, voilà qu'elle nous fascine de cela même que les nations des hommes connaissent actuellement de plus dominant entre toutes les nations: les États-Unis d'Amérique' [The clamour has left the bottom [of the ocean], and through you, sir, it now captivates us with the very thing that nations of humans currently know as the most dominant among all nations: the United States of America] (Glissant and Chamoiseau, 2009: 2-3).

While Obama's ancestors from Kenya and Kansas did not share with Glissant or Chamoiseau the past of the Middle Passage and enslavement, the election of Obama nonetheless represents the underground or undersea memory of the abyss that has surfaced from the bottom of the American sea of hatred to the centre-stage of North American, Caribbean and world political consciousness and power. It is through him that the abyss entered the political consciousness of the United States: 'Avec lui, la multiplicité est entrée dans la conscience politique du pays, après en avoir marqué le peuplement, la composition sociale, et les convulsions' [After him, multiplicity entered the political consciousness of the nation, after having shaped its demography, its social components, and its convulsions] (Chamoiseau and Glissant, 2009: 15).

Calling Obama 'son of the abyss' also avoids any epithet or definition that would stabilize Obama's human complexity and productive contradictions. The abyss defines him by the hollow, by a hole, which includes but surpasses all the epithets that attempt to seize him, such as, 'Barack Obama, superman', 'un Américain du tiers-monde' [a third-world American], '[L'homme aux] longues mains hypnotiques' [[The man with] long hypnotic hands], 'Barack Obama: Le Basket dans la peau' [Barack Obama: Basketball skin deep], to cite a few striking descriptions in the French press (Duriez, 2008; Jarreau, 2008; Giberné, 2008). 
The abyss shelters a beautiful onomastic disorder without containing or fixing it. The hope is that instead of stabilizing Obama the French are increasingly becoming destabilized in their own thinking of race because of Obama's defiance of categories; that words such as métis and their racialist roots will increasingly lose ground. This dynamism naturally also upsets US categories of racial thinking, as Louis Chude-Sokei has argued: 'Obama's run for the presidency carries the promise of spotlighting this "category crisis" at long last. There is the possibility of a conversation in which Africans in the US, along with other black immigrant groups, may emerge distinctly from the all-consuming category of "black"' (Chude-Sokei, 2007).

The concept of creolization, which Glissant sometimes equates to Relation, or gouffre, as opposed to the flattening and predictable position of the métis, enables the maintaining, around Obama, of a productive disorder. While reading the sign Obama through the lens of creolization theory, it is also crucial to acknowledge what the sign Obama brings to Martinique and to the world. Not only is Obama destabilized in a good way by the process of creolization but, also, his unclassifiable identity helps to destabilize French, American and Martinican categories of racial thinking.

Guadeloupean writer and playwright Alain Foix calls Obama a mutating man, who brings in his wake the mutation of his nation: 'Ce qui fait le caractère révolutionnaire de l'accession au pouvoir d'Obama signifié préalablement comme noir est le fait que ce nous en action est un état nouveau de la nation qui change littéralement de peau, une mue sociale, culturelle, politique et symbolique' [What is revolutionary in Obama's accession to power, a man previously signified as black, is the fact that this "we" at work defines a new state of the nation that literally sheds skin, a social, cultural, political, and symbolic shedding] (Foix, 2009: 66-67).

This is why Obama's surfacing as the face of one of the most imposing Western powers is revolutionary: in his radical performance of the reinvention of epidermalization. What was, for Fanon, the internalization of racial violence in the 'white world' and its projection onto the skin, having effects as disastrous as the literal disfigurement of the user of skin whiteners, or as young Barry's psychological wounds, becomes, with the election of Obama, a projection of the creolized skin onto the surface of the world, and onto the centre-stage of world power (see Fanon, 1952: 88-94). I am not claiming that the Fanonian form of epidermalization has magically disappeared from the surface of the earth with the election of Barack Obama. Nor am I arguing that the election of an African American man as the head of the United States has signalled the beginning of a post-racialized society and the end of racism. ${ }^{14}$

14 US social scientists have convincingly shown that racial discrimination 
I am simply indicating that his visibility slowly contributes to the rethinking of the realm of power that Fanon called 'the world' - read 'the white world' - by slowly dissociating the word 'world' from its accidental epithet 'white' (Fanon, 1952: 88, 103).

\section{Works Cited}

Amselle, Jean-Loup. 1999. 'Black, Blanc, Beur ou le fantasme du métissage'. In Sylvie Kandé (ed.), Discours sur le métissage, identités métisses: en quête d'Ariel. Paris: L'Harmattan: 35-46.

Appiah, Kwame Anthony. 2006. Cosmopolitanism: Ethics in a World of Strangers. New York and London: Norton.

Berlusconi, Silvio. 2008. 'Berlusconi Says Obama is "Tanned"'. BBC News.

8 November. <http://news.bbc.co.uk/2/hi/7715016.stm>. Consulted 11 December 2011.

Bonilla, Yarimar. 2010. 'The Politics of Audacity in Guadeloupe'. Paper presented at the Francophone Caribbean and North America Colloquium. Winthrop-King Institute for Contemporary French and Francophone Studies: Florida State University. February 2010.

Boulet-Gercourt, Philippe. 2008. 'Il fait aimer l’Amérique'. Le Nouvel Observateur. 5 June 2008.

Britton, Celia M. 1996. 'Eating Their Words: The Consumption of French Caribbean Literature'. In Peter Hawkins (ed.), ASCALF Yearbook. Bristol: Association for the Study of Caribbean and African Literature in French: 15-23.

remains an important concern in institutional, social, political, and psychological experiences. See, e.g., Hutchings, 2009: 938, who concludes that while 'the symbolism associated with the election of the first Black president certainly represents a milestone in American history ... the racial divide in political attitudes, as well as in social and economic outcomes, remains stubbornly immune to the passage of time.' Desmond King and Rogers M. Smith (2009: 25) similarly expose persisting concrete racial inequalities. Psychologist Thomas Pettigrew (2009: 285) notes: 'racial violence escalated and erupted in the North as well as the South [during Obama's campaign and thereafter]. Cross-burnings, threats, intimidation, and racist graffiti proliferated across the nation but typically did not receive nationwide publicity.' I would like to extend my gratitude to the participants of the Gustafson Seminar on 'The "Realities" of Race', at Emory University for sharing their interdisciplinary expertise on race in the US and particularly to Professors Regine O. Jackson and Amanda E. Lewis for recommending these articles. 
Chamoiseau, Patrick, and Édouard Glissant. 2009. L'Intraitable beauté du monde: adresse à Barack Obama. Paris: Galaadé.

Chesnais, Robert. Le Code noir. 1998. Paris: L’Esprit frappeur.

Chude-Sokei, Louis. 2007. 'Shades of Black'. Los Angeles Times 18 February 2007. <http://articles.latimes.com/2007/feb/18/opinion/op-chude-sokei18>. Consulted 11 December 2011.

Confiant, Raphaël. 2008. 'Barack Obama: un impérialiste comme les autres'. Montray Kreyol. 29 September 2008. <http://www.montraykreyol.org/spip. php?article1530)=fr.>. Consulted 11 December 2011.

—. 2009. 'Pitié pour Michael Jackson'. Union Générale des Travailleurs de Guadeloupe. 27 June 2009. <http://ugtg.org/article_970.html>. Consulted 11 December 2011.

Dash, J. Michael. 2004. 'Martinique/Mississippi: Édouard Glissant and Relational Insularity'. In Jon Smith and Deborah Cohn (eds), Look Away! The US South in New World Studies. Durham, NC and London: Duke University Press: 94-109.

Davis, F. James. 1991. Who Is Black? One Nation's Definition. University Park, TX: Penn State University Press.

Diawara, Manthia. 2008. 'Le Premier Candidat global'. Le Monde 4 June 2008.

Duriez, Isabelle. 2008. 'Obama, candidat très présentable'. Libération 5 January 2008.

Edwards, Brent Hayes. 2003. The Practice of Diaspora: Literature, Translation, and the Rise of Black Internationalism. Cambridge, MA and London: Harvard University Press.

Facebook. 'Martinican Obama Fan Club'. <http://www.facebook.com/group. php?gid=37797735558>. Consulted 11 December 2011 .

Fanon, Frantz. 1952. Peau noire, masques blancs. Paris: Éditions du Seuil.

Le Figaro. 2008. 'Seriez-vous prêts à voter pour un président noir en France?' 5 November 2008. <http://www.lefigaro.fr/elections-americaines-2008/2008/11/ 05/01017-20081105QCMW WW00109-seriez-vous-prets-a-voter-pour-unpresident-noir-en-france-.php)>. Consulted 11 December 2011.

Foix, Alain. 2009. Noir: de Toussaint Louverture à Barack Obama. Paris: Galaadé. Giberné, Pascal. 2008. 'Barack Obama, le basket dans la peau'. Le Monde 9 January 2008.

Glissant, Édouard. 1990. Poétique de la relation. Poétique III. Paris: Gallimard.

—. 1996. Introduction à une poétique du divers. Paris: Gallimard.

—. 1999. 'Métissage et créolisation'. In Sylvie Kandé (ed.), Discours sur le métissage, identités métisses: en quête d'Ariel. Paris: L'Harmattan: 47-53.

Goldhammer, Arthur. 2008. 'Le Monde on Obama'. French Politics Blog. <http:// artgoldhammer.blogspot.com/2008/03/le-monde-on-obama.html>. Consulted 11 December 2011. 
Hargreaves, Alec. 2007 [1995]. Multi-Ethnic France: Immigration, Politics, Culture and Society. New York: Routledge.

HighBeam Research. 2009. 'Martinique Salutes President Obama'. <http://www. encyclopedia.com/doc/1G1193001312.html>. Consulted 11 December 2011.

Hutchings, Vincent. 2009. 'Change or More of the Same? Evaluating Racial Attitudes in the Obama Era'. Public Opinion Quarterly 73.5: 917-42.

Jarreau, Patrick. 2008. 'Un candidat, américain du tiers-monde'. Le Monde 27 March 2008.

Kandé, Sylvie. (ed.). 1999. Discours sur le métissage, identités métisses: en quête d'Ariel. Paris: L'Harmattan.

KikiBird. 2008. 'Why Do French Women Love Obama?'. Eyes on Obama Blog. $<$ http://www.eyesonobama.com/blog/content/id_12384/title_French-womenlove-Obama/>. Consulted 11 December 2011.

King, Desmond, and Rogers M. Smith. 2009. 'Barack Obama and the Future of American Politics'. Du Bois Review 6.1: 25-35.

Loichot, Valérie. 2007. 'Between Breadfruit and Masala: Food Politics in Glissant's Martinique'. Callaloo 30.1: 124-37.

Mabry, Marcus. 2008. 'Where Whites Draw the Line'. New York Times 8 June 2008.

Nemo. 2009. Matinik Doubout. Paris: Alternative Libertaire.

Obama, Barack. 2004 [1995]. Dreams From My Father: A Story of Race and Inheritance. New York: Three Rivers Press.

—. 2008. 'A More Perfect Union'. Barack Obama. 18 March 2008. YouTube. $<$ http://www.youtube.com/watch?v=zrp-v2tHaDo $>$. Consulted 11 December 2011.

Pettigrew, Thomas. 2009. 'State of the Discipline: Post-Racism? Putting President Obama's Victory in Perspective'. Du Bois Review 6.1: 279-92.

Rosello, Mireille. 1998. Declining the Stereotype: Ethnicity and Representation in French Cultures. Hanover, NH and London: Dartmouth University Press.

Rousselin, Pierre. 2008. Editorial. 'Obama: Candidat historique'. Le Figaro Magazine 4 June 2008.

S-CREWW Productions. 2009. 'Obama martiniquais'. YouTube. <http://www. youtube.com/watch?v=-pj5mRVBJWA>. Consulted 11 December 2011.

Trethewey, Natasha. 2006. Native Guard. Boston, MA: Houghton Mifflin.

Vergès, Françoise. 1999. Monsters and Revolutionaries: Colonial Family Romance and Métissage. Durham, NC and London: Duke University Press. 


\title{
Richard Price \\ or the Canadian from Petite-Anse: \\ The Potential and the Limitations \\ of a Hybrid Anthropology
}

\author{
Christina Kullberg
}

On the cover of the second edition of Richard Price's The Convict and the Colonel: A Story of Colonialism and Resistance in the Caribbean (1998), Maryse Condé comments that the author's 'research is more fascinating than a piece of fiction'. American anthropologist Richard Price's study of the role of memory in modern Martinican society examines the strange fate of a social pariah, Médard Aribot, thief and artist, who, following his return from prison on Devil's Island, divided his time during the final years of his life between Petite-Anse and the town of Le Diamant in the south west of Martinique. The first 100 pages of the work set out the results of a scholarly anthropological investigation, combining documents and interviews conducted by Price on the life of Médard and on the furore surrounding the 1925 municipal elections in Le Diamant. The last portion of the book, by contrast, presents the anthropologist's own life: his encounter with Martinique and his reflections on the process of modernization that the island has undergone. This part aims to explore 'how one generation's powerful historical metaphors could so quickly become the next generation's trivial pursuit' (Price, 1998: 157).

Given the composite and often eclectic construction of this work which combines travel narratives, self-portraiture, documents, letters and critical commentaries, and in which we hear many different voices, it should come as no surprise that Price's anthropological work was cited by James Clifford in Writing Culture as a demonstration of the 'serious partiality' that characterizes a form of anthropology which inclines towards the literary. In Clifford's view, this approach has the virtue of defining the limits of certain epistemological ground rules in anthropological field work and of making explicit the fact that 
it is possible to gain knowledge of a culture without losing sight of the way in which that knowledge has been constructed (Clifford and Marcus, 1986: 7-8). Clifford is referring to Richard Price's First Time: The Historical Vision of an Afro-American People (Price, 1983). For Clifford this 'serious partiality' derives from Price's exposure of the constructed nature of knowledge and from a foregrounding of the techniques of writing. A fictional element (in the sense of fingere, to construct) is added to the scientific research and leads to a new conception of knowledge acquisition. In the promotion of Price's book its literary quality is given as much weight as its scientific significance: the constructed and fictional aspects of his writing are brought out in the material on the cover through quotations from critics who describe the book as a 'fusion', a 'mix' and a 'superb callaloo of a book'. Nevertheless, the text the reader is about to engage with contains no invention and while there are indeed a number of genres in operation in Price's narrative they can hardly be said to mix. They are juxtaposed and are mutually influential without ever really producing a fusion. This brings us back to Condé's remark. According to the novelist, The Convict and the Colonel is not a fiction, not even in part. While she certainly compares anthropological research with fiction, this is to enable her to distinguish between them. In Price, the discourse of knowledge is endowed with qualities which are associated with fiction. But this has very little to do with the truth value of certain fictional aspects of the anthropological narrative and it leads to a different form of knowledge. On the contrary, Condé presents the comparison she makes with fiction as the consequence of the effect on the reader of Price's research. She uses the concept of fiction in order to bring out the anthropologist's ability to convey sensations to the reader. We can thus see that this brief remark by the novelist offers a way out of the current impasse in the debate initiated by Writing Culture (Bonoli, 2007; Colley, 2005; Debaene, 2005; Foster, 1996; Jamin, 1986) on what constitutes fiction and what makes a science. As Debaene comments, the valorization of the fictionality of the anthropological narrative has lost its 'subversive scope' now that the concept of fiction has become banal (Debaene, 2005: 220).Whereas for some all writing has now become fiction, others are still looking for a new 'great divide' between fictional and anthropological narratives (Bonoli, 2007: 55).

This chapter aims to study the style and form of Price's book in order to demonstrate how certain poetic qualities of the anthropological narrative work to inhibit a fixed view of the other and to invite immediate engagement with a living representation whose quality makes it a worthy companion to recent Caribbean discourses that have defined the Creole world in terms of unpredictability and chaos (Glissant, 1990 and Benítez-Rojo, 1988). Taking Condé's observation as our starting point, we propose to view the question 
not as a tension between fictional and referential discourses but as evidence of the anthropologist's desire to use writing as a means to communicate a relationship with the world founded on involvement. The dividing line between matters pertaining to the science of anthropology and those which concern the effects of writing techniques effectively disappears when Price seeks to link the fate of Médard to his own life and that of a Martinican society caught up in a process of modernization. 'By taking the literary equivalents of the circuitous paths through the forest favoured by Médard', explains Price, 'I will try to shed light on how a people's central mnemonic for colonial repression could find itself transformed, in less than two decades, into the anodyne and picturesque icon on the cover of France's best-selling tourist guide to Martinique [published by Gallimard]' (Price, 1998: 157). It is clear from this that Price wants his style of writing to reproduce the wanderings of his object of study in order to give a better representation of a social reality. These words also justify his use of autobiography; in retracing Médard's travels, the latter having now become an emblematic figure of resistance and living memory, the anthropologist allows himself to move around between times, spaces and discourses. Thus, as Bonoli suggests, quoting Schaeffner, Price's narrative replaces the division between fiction and science with the pragmatic dimension of an anthropology which aims to make its readers see and experience its object of research in a move towards the poetic.

\section{The Anthropologist as Outsider}

The Convict and the Colonel opens with a prologue in which the anthropologist evokes a childhood memory of New York City during the Second World War that at first sight seems to have little to do with Martinique. In fact it is modernization which provides the link between the city and the Caribbean island. Just as Price once witnessed the modernization of New York, twenty years later he would become a witness to the transformation of Martinique. There then follow a hundred or so pages of relatively traditional field anthropology, which narrates, with supporting documents, the story of the events surrounding an election in Le Diamant in 1925 in which Médard was said to have been compromised. In accordance with the practices of dialogic anthropology the interviews allow Price's presence to be seen although he assigns himself a secondary role allowing his informant to speak without prompting. In parallel with the latter's narration, the reader is provided with the official version of the events of the election, described by the inhabitants of the town as the 'Le Diamant war'. There is thus a real concern for objectivity and care is taken to establish a link with the referent. The anthropologist allows free rein to his imagination only when he conjures 
up the years spent in prison. In the absence of any authentic witness accounts, Price imagines the sufferings of his subject without making any attempt to camouflage the fictional nature of the reconstruction he has produced from the available documents.

It is at the point where the anthropologist seeks to integrate Médard's fate with a contemporary Martinican society in which he himself is implicated that the question of the position of the foreign observer in relation to his object of study suddenly enters the narrative. In the spirit of postmodern theories of anthropology, Price exposes the weaknesses and the ethical and epistemological limits of his anthropological investigation, emphasizing the necessity of describing the process of knowledge acquisition as much as its results. Although he himself doesn't mention it, the extent of the impact of this approach is highlighted by the fact that it determines the relationship between the anthropologist and the Martinican society he studies. While the link to the referent remains crucial in his anthropological work, such considerations are as much epistemological in nature as they are poetic or even emotional. 'Though I cannot pretend to evoke the world [Médard] experienced, I would like at least to bear witness from my own perspective to that early 1960s world I shared with him' (Price, 1998: 175). Unable to describe Médard's lived experience, he turns instead to his own life, integrating his own memories with his research. The foreign observer must thus not only overcome a representational difficulty, he must also deal with the problem created by his own position. It would appear that the inclusion of his own life makes it easier to write about a society which, in spite of everything, is not his own. This is all the more important in that the severe criticism which the créolistes, a group of militant Martinican writers, have directed towards him is founded less on the relevance of his observations than on his status as an outsider. ${ }^{1}$ The reader soon learns that Price has lived for thirty or so years with his wife Sally, also an anthropologist, in the village of Petite-Anse

1 On the evidence of the recent debate on Creole identity in Martinique, the mistrust felt among writers towards external observers has increased. Since the 1980s, and in particular with the publication of the famous Eloge de la Créolité, Martinique, or rather an intellectual class on the island, would appear to be moving towards a rejection of the gaze of the other as it searches for its own identity as a community. Reactions to commentators on Martinican culture who have, what is more, dared to criticize créoliste discourse have always been violent and sometimes sexist (Lebrun, 1996). In any event, it is not our intention here to question the créolistes; others have done so before us and it seems counterproductive to linger too long over a problematic manifesto which was, after all, only a speech given at a festival. 
where he is known as 'the Canadian' and has gradually gained a reputation as a learned foreign scholar who is an authority on Médard's life. Whatever the créolistes may say, Price is certainly in the position of an insider.

The fact that Price repeatedly reminds us that he is not just any foreigner can be read as an indirect response to the créolistes' criticism. He does this elsewhere: for example, in a contribution he makes with his wife to the debate on the role of memory in Martinique. 'We are not studying people out "there" from a home base back "here", but rather engaging the intellectual agenda with people who are very much our peers in terms of their education, publishing involvements, and access to the media', they state in the article 'Shadowboxing in the Mangrove' (Price and Price, 1997: 3). Placing the emphasis on social group, education and access to the media rather than on ethnicity and origin, the Prices effectively construct a position for themselves which is at least to some extent that of insiders. It also demonstrates how aware Price is of this problem associated with anthropological research. In his formal choices, too, Price appears to have wanted to take advantage of his position as both insider and outsider to enhance his evocation in The Convict and the Colonel of a relationship with a society in a state of perpetual transformation. As the first foreigner to have gained the right to own land in the village, Price portrays himself as its adopted son, although he remains aware of his unusual status as a foreign researcher whose academic post in the United States allows him to divide his time between Petite-Anse, Virginia and Paris. He exploits this mobility most of all within the analysis itself, enacting an anthropological process which expands the notion of fieldwork by opening up the society under investigation to the movements of the anthropologist and of those he studies. The place and time of the investigation are no longer fixed, and it is characterized by a movement which is reflected in the narrative structure, shifting from place to place and from time to time.

Whereas the various locations involved in the fieldwork combine to create an impression of heterogeneity, the relationship between the researcher and the society he studies is articulated, rather, on a temporal plane. First, there is the memory of childhood which opens the study. The narration then shifts to a proper historico-ethnographical narrative of the 'Le Diamant war'. The following section combines the study of the years which Médard spent in jail with the narrative of Price's 1980s quest for traces of Médard. The final part likewise offers a combination of text types, in this case involving Price's autobiographical narrative of his arrival in Petite-Anse in 1962 as a young doctoral student in anthropology and a critical commentary on the tendency in assimilated Martinican society to idealize the past. Moreover, this eclectic mixture is accompanied by photographs and illustrations drawn from the different periods covered by the text. We are thus faced with a complex 
construction combining several temporal levels and linking together several spaces. It could even be described as a nested narration, being composed of several narratives in each of which the narrative voice adopts a different position: heterodiegetic in the Médard narrative and homodiegetic in the case of the more autobiographical narratives. The third part acts in some respects as a bridge between these two principal narrative levels, involving the evocation of the past in the present. This intellectual nomadism makes all the more apparent the less mobile character of the adherents of créolité. Bernabé, Chamoiseau and Confiant associate créolité with a particular place and culture, suggesting that Creole identity is innate, not acquired. Price, by contrast, plays with different standpoints, drawing on other locations and periods in order to construct a heterogeneity within his work which can be described as Creole. The narrative and metatextual play accordingly allow him to engage in the Creole world while representing it.

The juxtaposition of the autobiographical and anthropological narratives establishes points of contact between Price and his object of study on an emotional level. His own narrative is coloured by a marked nostalgia: nostalgia for his youth; for the birth of love; nostalgia, too, for his first experiences of fieldwork (he had previously carried out research in Peru). This last introduces touches to the narrative of his sojourn in Petite-Anse in the summer of 1962 that evoke rites of initiation. This period will subsequently be identified as a pivotal one for Martinican society which, according to Price, was at that time on the threshold of modernization. It would be required to undergo this process very rapidly at the time of the French annexation which made the island a département d'outre-mer. 'I would argue that the early 1960s in fact marked a watershed in Martinique' (Price, 1998: 180), writes Price, after criticizing the patent nostalgia for 'ancestral life' in 1990s Martinique. Price can thus claim that, like the inhabitants of Petite-Anse and like the writers of créolité, he too has had experience of the shift from a rural society to a modern one comprised of motorways, supermarkets, hotel complexes and so on, all funded by France. But the migration of the narrative 'I' from the autobiographical sections into the anthropological ones makes it hard to separate the nostalgia felt by Price himself from that which he is the first to detect in contemporary Martinican society. The shifts in position implied by the combination of the different discourses become vanishing points in the picture he paints of Martinique. Just as this interplay brings one narrative ' $\mathrm{I}$ ' closer to the world under investigation, so the other one is distanced from it. 


\section{A Poetics of Involvement}

A double movement of involvement and distance governs the relationship set up with Médard. Although Price never met him in person and first heard of him only in passing in 1978, the Martinique encountered by the young doctoral student was the same country as that of his hero. On this matter, it is interesting to note that he left Martinique after completing his thesis on the superstitions associated with fishing in Petite-Anse to work on the maroons in Saramanka (Price, 1998: 250 n. 36). Curiously, his rediscovery of Martinique as an object of anthropological study therefore happened to come about at the same time as the créolistes were publishing their first works although this coincidence is barely touched on by him. It was an encounter with a part of Martinique previously unknown to him which inspired him to turn his attention once again towards the island which had in the meantime become his new home. The result is a strange piece of fieldwork that lasted more than ten years and was punctuated by a series of comings and goings between various locations. The facts on Médard's life appear in an unordered way, woven across the years into the narratives which make up the book. It can thus be said that the conditions of research were partly responsible for the hybridity of The Convict and the Colonel.

However, despite the many links established by Price between his own life and that of his adopted island, the anthropologist also generates a certain distance in his writing. This distance is even the necessary condition for the anthropological narrative and its expression. An external viewpoint can be said to be required if Price is to produce a hybrid anthropological form of writing that combines research and self-reflexion. The staging of a distance which is then superseded is thus the result of a conscious strategy on Price's part to achieve the exploration of relationships with the world.

Despite his metatextual awareness, Price does not sense the mediation inherent to this relationship with the world. He never remarks on the fact that the play between levels and positions, the tensions between distance and involvement, are also to be found in his style. The sections on the elections in Le Diamant, on Médard's life and those containing the interviews with local people who were alive during the period in question, some of whom even knew Médard, are written in a more scientific and neutral style. For example, the author almost exclusively employs the present tense and reported speech, and his sources are annotated, analysed and transcribed in the endnotes. The 'I' who is represented here guarantees the process of gathering informants' statements and explains where choices have been made, while sometimes slipping into the academic 'we' (Price, 1998: 5). In those sections which tell the story of the elections and Médard's life in prison we encounter an authen- 
tically historical style of narrative with a focus on action and almost devoid of description. This contrasts with the passages which narrate the search for traces of Médard carried out by Price in the 1980s in preparation for his book. Suddenly, the historical discourse is replaced by descriptions and narratives which plunge the reader into the heart of events.

We were rattling up the dirt track to Morne l'Afrique, high above the bay of Diamant, squeezed into the front seat of Julien's dilapidated pickup truck, its doors tied shut by lengths of rope - Julien, his wife Tina, Sally and me. A kind of joyous Sunday outing, in search of traces of Médard, of people who might have known him, people who might be willing to share their reminiscences. We pull up even with a very old man, walking up the steep slope leaning on a staff. 'Good afternoon', greets Tina out the window in Creole. 'Good afternoon, Madame,' he answers, gracefully tipping his bakoua. 'We're looking for the place where Méda used to live, you know the man who -' 'Madame, no one ever got to the bottom of that fellow! What a tremendous secret he had! ... His house is further up the hill, at Bompì, but it's hard to find, you'll have to ask.' We thank him, and Julien grinds the old Peugeot into first gear for the climb.

Farther along, by the side of the road, we come upon an elderly man lifting a sack of charcoal onto his head. Had he known Médard? We ask, again out the window. 'He was a genius - a genius without the diploma', he replies without hesitation. Could he tell us where Médard had lived? 'I'll bring you there, it's on the path I am taking myself.' So, we pull over to the side and, on Julien's insistence, cut staffs against the snakes and follow the man down a path toward the setting sun.

The scenery takes our breath away. The whole bay of Diamant is spread out at our feet, the white foam of breakers washing the distant beach, and Diamond Rock floating in a sea of turquoise. To the right rises the deep green slope of Morne Larcher, a worn volcanic cone and the highest peak on the island's south. We slip and slide down the narrow path, trying to keep the old man in sight, converting our snake-killers into walking sticks on the steep terrain. Finally he yells up at us and points in the direction of the only house in the little side valley. [...]

This tiny house sits at the edge of a deep ravine amidst lush vegetation - bananas, papayas, lime trees, callalou plants. It's in a verdant cul-de-sac, backed against the hill, and facing, across the ravine, the sweep of the bay and Diamond Rock. (Price, 1998: 53-54)

The above description of a research trip to find information on Médard opens the second chapter. For all that this passage forms part of an anthropological, scientific and referential narrative, we are here fully immersed in 
a novelistic style reminiscent of travel narratives. Its structure, moreover, is that of a detective story: the reader wants to know if Price and his friends will succeed in finding what they are looking for. The description of the setting is detailed and affectionate, as is that of the people he encounters along the way. The portraits of the elderly gentlemen, whose politeness and accoutrements (the bakoua hat and sack of charcoal) evoke a bygone age, add to an effect of wildness in the scenery in their indirect suggestion of a temporal shift. We should also note that their reminiscences concerning Médard are proof, with no need for explanation by Price, of the existence of the living memories sought by the anthropologist. For them, Médard is a legend, a real myth whose memory has not faded. What is more, these exchanges provide the narrative with authenticity and life. Imperceptibly, the tense of the narration shifts towards the present as though about to come to a halt at the end of the passage in front of the splendid view which appears as the group arrive at Médard's house.

However, if fiction is simply equated with evidence of composition, this passage is no more 'fictional' than the more scientific passages, since the latter are just as crafted as this one. In one of the historico-anthropological sections, for example, Price uses a collage technique where he provides parallel accounts of the events of the 1925 election, supplying the right-wing point of view in one column and the left-wing view in the other. The difference lies in the fact that in the above passage the relationship with the world is mediated. It is thus the mode of expression which has changed, not the compositional complexity of the narrative. The logic of this passage is more that of poetry than science; the adjectives and descriptions are markers of a relationship with the world based on feeling. Equally, the landscape which the narrator portrays for us is presented from the point of view of a subject involved in an action which renders the description dynamic. This way of making the description dependent on a subject corresponds to the demands of literary discourse and not of a scientific discourse within which a description would not be legitimated by the presence of a subject. Moreover, the narrative 'I' in the passage expresses an emotional relationship with the surroundings it describes in contrast with the 'I' of the purely anthropological sections where information is accessed more directly. But, above all, the author establishes a different relationship with the reader founded on an appeal to the latter's imagination. The style, based on a concept of engagement and involvement, is designed to involve the reader in the moment of discovery of Médard's house. Although Price has long been familiar with Morne l'Afrique and its surrounding area, he uses a style associated with the experience of the new to paint a panoramic view of the Caribbean sea. Put differently, he composes the passage in such a way as to encourage the reader to discover the sea with 
him as if for the first time and to produce an effect of identification. ${ }^{2}$ This is an essential technique for an author who considers that his audience should first and foremost be able to find themselves in any representation of the past. The particular construction of the narrative not only demonstrates the shifts in position that underlie all anthropological narratives but also provides it with a poetic frame, moving beyond the anthropological context. The result is a strange tension between participation and distance, and the reader 'falls under the spell' of Price's narrative, as Condé suggests.

The recourse to literary techniques demonstrated by such shifts in expressive modality is in no way a break with the referent. Price's writing challenges the idea that the dividing line between fiction and science in anthropology is determined by the relationship with the referent: in such a view scientific discourse would report true events while fiction would be the fruit of invention. In Price, by contrast, it is literary style itself which creates the connection between the researcher and reality and, moreover, between the reader and the Creole world. We can suggest, following Bonoli, that the '[texte] ethnographique apparaît ainsi comme le résultat d'un effort imaginatif qui construit une forme médiatrice, à partir de notre langage, qui nous permet de voir l'autre comme ce qui est présenté dans le texte' [The ethnographic [text] thus appears as the result of an imaginative effort that constructs a mediating form whose starting point is our language use and which allows us to see the other as that which is presented in the text] (Bonoli, 2007: 56). The imaginative element does not compromise the referentiality of the discourse; its function is to allow the reader to visualize the world under observation. Anthropology and fiction share a referential force. In addition, Price submerges himself, as we have seen, in the experience of research. No sooner is otherness constructed than it is wiped out by a process of identification founded on feeling. Involvement, as a product of style, serves as proof to the extent that Price, in this age of commemoration, bases his system of argument on the fate of memory as observed in the field. He himself becomes a witness to what he is about to describe and uses himself to test out the argument and convince us of its validity. It is as though the literary mode of his expression served both to move and to convince the reader.

2 We can compare this description with the first time that Price sees Petite-Anse during the 1960s: 'In June 1962, from the top of a hill in Martinique, I looked down for the first time on what I saw as a spectacularly beautiful, isolated fishing village - Petite-Anse - rimming the blue Caribbean' (Price, 1998: x). It also reminds us of the view of the house currently inhabited by the Prices (see $<$ http://www.richandsally.net/>). 


\section{Concluding Thoughts: An Anthropology of Creolization?}

Price's style is neverthless far from unique, but belongs within a particular movement which has been described as a Caribbean anthropology. His methodology reminds us of what Glissant, in an article on Michel Leiris, calls an 'ethnographie de la Relation' [ethnography of Relation] explicitly linked to Creole experience:

Toute ethnographie des Antilles cesse d'être strictement récapitulative, engage dans le présent tout un avenir, force à considérer les relations entre cultures, à prendre position sur les heurts entre cultures et confirme (malgré le racisme qui sévit dans ces pays) qu'il n'est pas utopique de concevoir l'avènement un jour d'une véritable civilisation composite. ${ }^{3}$ (Glissant, 1969: 127)

In his own unique formulation, the Martinican author dreams of a processual ethnography which would be able to grasp experience as it is lived, to track its movements and transformations, and which would aim to demonstrate that belief in a future composite society is not utopian. According to Glissant, in order to approach Caribbean reality, anthropological discourse must abandon its realist aspirations; its aim should not be simply to make observations in the field and then reproduce those observations. On the contrary, it must not only focus on contemporary encounters but must also create an active role for anthropological narrative in the society which is being created. This concept of a representation of Creole society which can itself be described as creolizing is to be found in the créoliste writers who define créolité as 'le monde diffracté, mais recomposé, un maelström de signifiés dans un signifiant: une Totalité' [the diffracted but reconstructed world, a maelstrom of signifieds in a signifier: a Totality] (Bernabé, Chamoiseau and Confiant, 1989: 27); a 'spécificité ouverte' [open specificity] lived as a question and whose expression is 'réservée à l'art' [reserved for art] (ibid.: 29). With regard to the valorization of the processual in the expression of the Creole world, an issue which is as important to the créolistes as it is to Glissant, we can note that the hybrid composition of The Convict and the Colonel, which appeared about ten years after Éloge de la Créolité, is evidence of the quest shared by

3 'Any ethnography of the Antilles is no longer strictly recapitulative in nature, engages an entire future in the present, requires us to reflect on relationships between cultures, to take a stance on clashes between cultures and confirms (despite the racism which is rife in these countries) that it is not utopian to envisage the eventual appearance of a truly composite civilization.' 
Price and the Martinican authors for a form fit to capture the heterogeneity of the Creole world.

This idea reappears in another anthropological study published in the same year as The Convict and the Colonel, with a preface by Price: Michèle-Baj Strobel's Les Gens de l'or (1998). Like Price, she attempts to engage with her object of study on a formal level through the construction of a narrative, which, like the rivers of Guyana which are so crucial to the life of the gold washers she studies, moves forward in a series of meanders. Strobel draws on Michel Foucault in her explanation of the need to turn to aesthetics when engaging with the silence of histories for which no archive exists. 'Il faut être autant requis par une vibration émotionnelle et esthétique que par les rigueurs des recherches de la rationalité' [You have as much to respond to an emotional and aesthetic call as conform to the the rigours of rational research] (Strobel, 1998: 57). She expands on this later in relation to Creole culture:

S'il fallait rattacher les cultures d'abatis créole à une esthétique ce serait évidemment celle de l'assemblage-collage, ou plus exactement par analogie avec le tissage - activité corrélée à la culture d'un champ, comme on le sait - celle des twèl konwé (toiles des convois) ou patchwork, que les femmes créoles fabriquaient en assemblant les morceaux de vieux tissus et les rubans usagés. ${ }^{4}$ (Strobel, 1998: 134)

A surrealist aesthetic of collage is here compared to the cultivation of the land and to weaving. The same analogies could describe her own book as well as Price's. It is as if these anthropologists were attempting, through the fragmented and heteroclite form of their narratives, to leave the reader with a physical impression of the movement of the underground memory and the composite culture they study. Form and content are bound together in the chaos of their narratives. More than a concern for truth, it is the desire to establish a physical relationship with the world which causes Price to break up his narrative and to juxtapose various discourses in order better to grasp the ineffable aspect of his subject matter: the transformation of a society. Thus we can suggest that an aesthetic imperative is to be found running through writings on the Caribbean insofar as writers and anthropologists

4 'Were it necessary to link the cultivation of the Creole abatis to an aesthetic it would clearly be that of assembly-collage or, to be more precise, by analogy with weaving - an activity which correlates to the cultivation of a field, as we know - in particular the work known as twèl konwé (convoy canvases) or patchwork, which the Creole women created by combining scraps of old fabrics and worn ribbons.' 
agree that the representation of an elusive Caribbean reality needs to be realized in terms of poetics rather than mimesis.

Equally, the only reason that many theoreticians of hybridity, including Clifford, have explored Creole cultures has been the desire to discover in them the promise of a future world and the transformation of the scientific paradigm into a processual and hybrid form of knowledge, emerging out of 'a more ambiguous "Caribbean" experience' (Clifford, 1988: 15). However, the analysis of Price's study allows us to realize that while creolized societies invite the anthropologist to make use of fragments and myriad discourses to stage a relationship with the shifting world, and while this process certainly breaks the links with monocultural tradition, as Clifford suggests in relation to the Caribbean experience, contrasting it with a traditional anthropology which would focus exclusively on one culture henceforth isolated and fixed in time and space (ibid.: 14), it does not constitute a break on the level of the mode of expression. On the contrary, the idea of matching form to content is derived from a classical paradigm. Although the eclecticism which characterizes writings on Martinique, whether anthropological or fictional, hardly figures in Boileau's hierarchy of the genres of Belles Lettres, for instance, it is still the case that the idea that the style should reflect the content is a profoundly classical one. In the same way, Price has recourse to literary techniques in order better to instruct, please and move his reader - an ideal which finds a distant echo in the classical aesthetic. As regards description, the incorporation of a human point of view in the portrayal of nature, such as we have seen in Price's text, belongs according to Philippe Hamon within an aesthetic of description specific to the classical age, in which a description lacking any human reference would have been judged excessive and, above all, uninteresting (Hamon, 1993: 17 and 25). On the other hand, Price remains a modern writer/anthropologist who, in line with Rousseau and romanticism, uses the harmony of form and subject matter not in order to create a distancing effect, to adopt the term that Thomas Pavel uses to conceptualize the aspirations of classical literature (Pavel, 1996), but rather an effect of involvement. The Pricean movere therefore operates in a different mode, one of the reader's identification and participation on a horizontal rather than a vertical level.

However, the analogy with classicism demonstrates that we would be wrong to attach a priori a subversive value to this 'creolizing' writing. Hybridity in and of itself is never processual and can never liberate us from monoculturalism, since in doing so it would risk becoming fixed in a form which would only repeat a pre-established image. In the case of Price's book, we can see that although he creates a hybrid form of anthropology the content of his narrative reveals a trend in the opposite direction: Martinican 
society has become less composite than ever under the pressures of assimilation. In his demonstration of how Médard appears in the imagination of the villagers he suggests that in the reminiscences they produce of this curious figure we might detect the existence of a living and subterranean memory that invalidates theoretical claims that the Caribbean has no past (Price, 1998: 171-73). The problem is thus not the absence of history but the gradual erasure, under the pressure of assimilation, of a certain form of memory. By combining scientific research with the story of his life, Price's narrative attempts to recreate this living memory in writing. ${ }^{5}$ Although Price shares the concerns of many writers from Martinique, in particular the signatories to the manifesto of créolité, his narrative also exposes the dangers of monumentalizing the past by divorcing it from the present.

This chapter thus claims that for Price the literary features of anthropological narrative, which, since Writing Culture, would seem to number among the commonplaces of anthropology (Debaene, 2005), have a function that goes beyond the demonstration of the awakening of anthropology's self-critical faculties or the construction of a new object of knowledge. In his book, the inclusion of the researcher as an object of study, the fragmentation of the narrative and the poetic style would appear, rather, to be intended to reflect this world in transition and this underground Creole memory, and also to involve the reader in them. In the Caribbean, the past does not deliver itself directly into the hands of the observer. It is hidden and calls for the alternative logic of interpretation offered to us by Price in the book. To trace out underground memory we must look for it in 'hidden layers of history, called by other names and inscribed not in books (the people among whom we lived were barely literate), but in language, in proverbs, in metaphors, and in the land (and sea) itself' (Price, 1998: 171). According to this argument, it is the imaginative dimension of the referent itself which provides the justification for the poetic quality of the anthropological narrative. If memory remains unarticulated and exists in the Creole world only in the form of the fragment, the formal and narrative fragmentation of the book is intended to reproduce it. Its logic is one of continuity, not of rupture. Price invites his audience to read The Convict and the Colonel in the same way that he himself has had to interpret the Creole world in order to understand it and to follow it on its transitional path towards new times.

5 Curiously, when translated into French, Price's book became caught in this very trap, as the official launch praised his revival of a forgotten part of Martinican heritage. Price himself comments on this in the epilogue of the second English edition. 


\section{Works Cited}

Benítez-Rojo, Antonio. 1998. La Isla que se repite. Barcelona: Editorial Casiopea.

Bernabé, Jean, Patrick Chamoiseau and Raphaël Confiant. 1989. Éloge de la Créolité. Paris: Gallimard.

Bonoli, Lorenzo. 2007. 'Fiction, épistémologie et sciences humaines'. A contrario 5.1: $51-66$.

Clifford, James. 1988. The Predicament of Culture: Twentieth Century Ethnography, Literature, and Art. Cambridge, MA: Harvard University Press.

Clifford, James, and George E. Marcus (eds). 1986. Writing Culture: The Poetics and Politics of Ethnography. Berkeley and Los Angeles: California University Press.

Colleyn, Jean-Paul. 2005. 'Fiction et fictions en anthropologie'. L'Homme 175-76: 147-63.

Debaene, Vincent. 2005. 'Ethnographie / fiction / littérature: à propos de quelques confusions et faux paradoxes'. L'Homme 175-76: 219-32.

Foster, Hal. 1996. The Return of the Real: The Avant-Garde at the End of the Century. Cambridge, MA: MIT Press.

Glissant, Édouard. 1990. Poétique de la relation. Poétique III. Paris: Gallimard.

—. 1996 [1969]. L'Intention poétique. Paris: Gallimard.

Hamon, Philippe. 1993. Du descriptif. Paris: Hachette.

Jamin, Jean. 1986. 'L'Ethnographie mode d'inemploi: de quelques rapports de l'ethnologie avec le malaise dans la civilisation'. In Jacques Hainard and Roland Kaehr (eds), Le Mal et la douleur. Neuchâtel: Musée d'ethnographie: 45-79.

Lebrun, Annie. 1996. Statue cou coupé. Paris: Jean-Michel Place.

Pavel, Thomas. 1996. L’Art de l'éloignement: essai sur l'imagination classique. Paris: Gallimard.

Price, Richard. 1983. First Time: The Historical Vision of an Afro-American People. Baltimore, MD: Johns Hopkins University Press.

- . 1998. The Convict and the Colonel: A Story of Colonialism and Resistance in the Caribbean. New York: Beacon Press.

Price, Richard, and Sally Price. 1997. 'Shadowboxing in the Mangrove'. Cultural Anthropology 12.1: 3-36.

Strobel, Michèle-Baj. 1998. Les Gens de l’or: mémoire des orpailleurs créole du Maroni. Petit-Bourg: Ibis rouge. 

Music 



\title{
'Fightin' the Future': Rhythm and Creolization in the Circum-Caribbean
}

\author{
Martin Munro
}

The plantation societies of the Americas were set up essentially as modern, profit-driven machines that used human beings as combustible, disposable parts. Far from nurturing cohesive communities, European colonists created anti-societies that relied on the continuous supply and consumption of bodies uprooted and thrown out of step, out of rhythm with the places and cultures they were born into. In the colonial Caribbean, where the indigenous population was more or less wiped out by illness and warfare, the new populations comprised many disparate groups of African slaves and a number of European nationalities. Set up to be dystopian, segregated work factories, these societies lacked the basic rhythmic socialization (a common, functional understanding of time, culture and work) that has been a fundamental element in bonding communities from the beginning of human history. And yet, among the enslaved people more organic and benign rhythms persisted and helped them survive the plantation and its anti-rhythmic foundations. Crucially, however, rhythm was not the property of one group, and it became one of the most effective means of transgressing social and racial divides, and in creating the unique social order and culture of the circum-Caribbean, the expanded regional space that includes the insular Caribbean and the countries linked to it by the sea and history. This chapter considers ways in which rhythm has functioned and continues to serve as a particularly malleable and persistent social and cultural element both in the Caribbean and in the American South, two sites that are connected historically through similarities in the physical and social configuration of the plantation and the societies that have emerged from it. 
The initial focus on James Brown's rhythmic innovations in the 1960s identifies some of the salient aspects of his rhythms, and suggests some of the ways in which Brown ushered in an era in popular music in which rhythm has arguably become the predominant formal and stylistic element. Brown's rhythms were seized upon by Black Power militants and incorporated into a notion of black aesthetics that served a politicized idea of African-American culture as a largely homogeneous, untainted entity. At the same time, Brown himself was less inclined to consider his rhythms to be echoes of a recoverable racial past, and instead preferred to read them as pre-echoes of the future, and of sounds and ways of thinking that were yet to be realized. The chapter discusses Brown's rhythms in relation to other instances in the Caribbean that show the importance of rhythm at moments of social and personal transformation. Rhythm, it is argued, has been a primary force in creating these creolized societies, and remains a fundamental part of the circumCaribbean world, a zone shaped by a common, interconnected history that 'travels with the seas' (Glissant, 2000: 29).

\section{The New Bag}

Revolutions can start in quite innocuous ways, without anyone being aware of the future significance of a certain action, speech or innovation. When James Brown released 'Out of Sight' in 1964 few commentators realized the significance of the moment, or that the track was an audacious step into a new mode, the first pre-echo of the sound of the future. That future, that revolution was built on and made up of rhythm (Guralnick, 2002: 239).

As its title boldly promised, 'Out of Sight' propelled James Brown into a new mode, almost a new dimension of music that was far removed from that of any of his peers. While the song retained something of a basic blues structure, its staccato bass lead, sharp horns, and most of all its driving, irresistible rhythm marked a departure at once from the gospel roots of much of Brown's previous work, and from the conventional melodic structures of Western music. This new thing was the rhythm as song, the song as rhythm. As he would write later, 'Out of Sight' marked a new direction for Brown's music: 'Everything about it was new,' he says, 'the rhythm, the arrangement, the lyrics, and the way the beat kept on jerking up and hitting' (Brown, 2005: 124-25).

James Brown's rhythm revolution stalled for a year after 'Out of Sight' as he worked out his business problems and finally returned to the King label. The hiatus seemed only to foment the revolution, and when he came back in July 1965 the new rhythmic sound developed in spectacular fashion with the release of 'Papa's Got a Brand New Bag'. Recorded in typical, 
improvisatory James Brown style, in less than an hour on the way to a gig, at the post-production stage the track had its intro spliced off and its entire performance speeded up for release (White and Weinger, 1991: 27). Announcing itself with its unexpected light, early accent on an expected strong beat, the rhythm is set with a short toot from the horns, 'a marked attack played as if it were a little early in relation to the basic pulse implied by the rest of the rhythmic fabric' (Danielsen, 2006: 73). In James Brown's own words, this track 'had its own sound: the music on one-and-three, the downbeat, in anticipation' (Brown, 1991: 3). Brown soon adopted 'rhythm on One' as a personal slogan, and the technique itself of playing the One on top, or, as he puts it, a downbeat in anticipation, later became central to the funk sound of the seventies. ${ }^{1}$ He had discovered, he says, "the power of the percussive upbeat, using the rhythm in an untraditional way [...]. I didn't need "melody" to make music. That was, to me, old-fashioned and out of step. I now realized that I could compose and sing a song that used one chord or at the most two' (Brown, 2005: 80).

For James Brown, 'Papa's Got a Brand New Bag' was a statement of black musical independence, 'something that would give us a place in the business'. It was, moreover, a new idiom, 'a slang that would relate to the man in the street' (Brown, 1991: 3). Despite (or, indeed, because of) its atypical, jarringly rhythmic sound, 'Papa's Got a Brand New Bag' was James Brown's first Top 10 hit; moreover, as Dave Marsh says, it declared a 'new order of rhythm and himself as its avatar' (Marsh, 1989: 4). Both the success of the song and its form, its sound, took Brown by surprise: as it hit the charts he told the disc jockey Alan Leeds that 'It's a little beyond me right now. [...] If you're thinking, "well, maybe this guy is crazy," take any record off your stack and put it on your box, even a James Brown record, and you won't find one that sounds like this one. It's a new bag, just like I sang.' Perhaps most tellingly, Brown suggests that the new phenomenon is something almost strange to him and his time, a prophecy of music to come that had an almost unnerving effect on him: 'It's - it's - it's just out there,' he says. 'I'm actually fightin' the future' (quoted in White and Weinger, 1991: 27; emphasis in original). In the

1 Later, to be 'on the One' came to mean more generally to be in rhythmic harmony. As Vincent says, 'When George Clinton is heard chanting onstage, "On the one, everybody on the one," he isn't trying to get his band on the beat (they are already there), he is savoring the rhythmic lock that has brought the entire house together, as one' (Vincent, 1996: 37). Cynthia Rose makes a similar point about funk's rhythmic harmony when she says that it 'is not a reconciliation of opposite rhythmic impulses, but the fusion and transcending of their essential conflict' (Rose, 1990: 53; emphasis in original). 
mid-sixties, Brown says he was not seeking to reproduce 'some known sound' but was 'aimin' for what I could hear. "James Brown Anticipation" I'd call it. You see, the thing was ahead' (Rose, 1990: 59). 'Papa's Got a Brand New Bag' retains that portentous quality, the sense of a rhythmic prophecy that is still being played out, that is still itself 'fightin' the future'. As Dave Marsh says, in the mid-sixties, James Brown 'invented the rhythmic future in which we live today' (Marsh, 1989: 5). ${ }^{2}$

James Brown's musical innovations in the 1960s and 1970s may be the best known and most influential elements in creating the 'rhythmic future' in which we and our music still exist, but he is far from being the only artist from the circum-Caribbean to evoke and remould rhythm in the modern era as a harbinger of times and states of being to come. Indeed, rhythm is conspicuous at virtually every major social and cultural turning point across the circum-Caribbean, in key movements such as Negritude, the Harlem Renaissance, Afrocubanismo and Haitian indigenism. What is fascinating, too, is that while rhythm is in some ways an ancient element in human cultures, it also carries the prophetic qualities that Brown sensed; counter to a folkloric or culturally nationalist understanding of rhythm, he insists that what he was doing was 'untraditional', ahead of him, not yet realized in sound. Rhythm embodies at once a deep cultural and social memory and a reality that is yet to come, and is forever oriented to the future. As Brown says, to be aware of this is always to 'fight the future', to sense what is coming and to be directed towards that future. In his case, the rhythm revolution was part of a broader social and cultural movement that challenged racism and asserted black American culture on its own terms; the freer, less-constrained future that the rhythms portended was as much a social phenomenon as a radical change in musical style. In the remainder of this chapter I will identify and analyse other such rhythmic-musical-social moments in circum-Caribbean history and show some of the ways in which rhythm manifests itself at crucial times as a portent of the future and as a marker of a desire to live in that future. Also, I will suggest that rhythm in the region is one of the most durable and adaptable markers of creolization - broadly speaking, the cultural and social processes that result from the meeting in the Americas of disparate cultures and peoples. ${ }^{3}$

2 Craig Werner similarly argues that “Papa's Got a Brand New Bag” unleashed a polyrhythmic ferocity that eventually reconfigured every corner of the American soundscape' (Werner, 2006: 138).

3 For a fuller discussion of these ideas, see Munro, 2010. 


\section{Rhythm and Haitian Indigenism}

Conventionally seen as an element of popular, 'low' culture, rhythm has often been neglected and disowned by Caribbean elites as a sign of the putatively backward African culture of the (often darker-skinned) masses. Yet, at crucial times in national and regional history, the intellectual elites have turned to rhythm, and strategically sought to incorporate it into anti-colonial or nationalist conceptions of culture, race and society. In this sense, rhythm crosses boundaries of 'high' and 'low' cultures, more effectively perhaps than virtually any other cultural element. The case of Haitian indigenism exemplifies this cultural fluidity and rhythm's strategic displacement from popular to elite culture, again as a means of envisioning a future free from the failings and prejudices of the past.

It is one of the enduring paradoxes of the first black republic in the New World that it has long neglected and repressed, or else selectively appropriated, the 'blackest' parts of its culture, chiefly its religion and its associated rhythmic music and dance. In postcolonial Haiti, rhythm, so long feared by the French colonists as an instigator of slave revolt, was subjected to renewed state control, as the nation struggled to reconcile its modern, Westernized idea of itself with its dynamic, non-Western, yet ever-creolizing cultural traditions. From Toussaint Louverture's laws banning 'Vaudoux' dances, to the anti-superstition campaigns of the 1940s, Haitian elites, often in collaboration with the Catholic Church, have fought a determined campaign against the drumming, dance and rhythm of the masses. In doing so, the elites have effectively waged an anti-rhythm crusade that attacks the very foundations of popular culture in Haiti. For the drum and rhythm occupy a privileged place in Vodou culture. As Alfred Métraux wrote in the mid-twentieth century, the drums symbolize Vodou, and the term 'battre tambour' [to beat the drum] signifies in the popular language, 'célébrer le culte des loa' [to celebrate the cult of the $l w a$ ]. The political importance of the drum is shown throughout Haitian history, Métraux says, in the way that it has been regularly prohibited by the state in its campaigns against 'paganism'. Even if he is not a serviteur himself, the drummer is the mainspring of every Vodou ceremony; it is his 'science du rythme' [science of rhythm] and vigorous beats that determine the ardour of the dancers, and the intensity of the nervous tension that allows the dancers in turn to attain the desired trance-like state (Métraux, 1958: 159). The drum in Haitian Vodou is, however, more than a mere musical instrument; it is also, as Métraux says, 'un objet sacré et même la forme tangible d'une divinité' [a sacred object and even the tangible form of a divinity]. Believed to contain a 'puissance mystérieuse' [mysterious power], the drum is the first of the sacred objects that the serviteurs salute before the 
ceremony starts, and the priests themselves, the houngan and the mambo, will in the course of the ceremony come to kiss the earth before the drums and to pour libations on them (Métraux, 1958: 163).

On the one hand, therefore, the drum and rhythm were reviled and rejected by the elite, and on the other they were the very foundations of the sophisticated cultural and metaphysical system of the masses. Among the elite, Vodou was associated with Africa, and thus with barbarism and primitivism, and for that group the only civilization worth considering in the post-independence period was that of Europe (Nicholls, 1981: 42-43). At the same time, early Haitian intellectuals were wary of being subsumed into this broader, Western civilization. Haiti's uniqueness was held by some to lie in its distinctly hybrid culture. In 1836, for example, the author Émile Nau wrote of how both Haiti and the United States were 'transplanted' nations, 'stripped of traditions', and of how the particular fusion of European and African cultures in Haiti made it 'less French than the American is English' (quoted in Dash, 1998: 46). And yet, if Nau did indeed see Haiti as the primary exemplar of the 'heterogeneous modern American nation' (ibid.), the post-independence history of Vodou indicates the trouble the nation had in assuming this creolized identity and culture. Haiti was a modern state in terms of its early postcolonial status and also of its hybrid racial and cultural composition. ${ }^{4}$ This modern status was not attained through a steady process of change, but through violent, cataclysmic change and upheaval.

In a sense, Haiti's modernity was thrust upon it, and was hurriedly and incompletely, if also enthusiastically and willingly, assumed. This was a new relationship with and conception of modernity; an early example of the 'lived' modernity that Glissant associates with the Americas in general, and which was not 'developed over extended historical space' but was 'abruptly imposed' (Glissant, 1989: 148). This lived modernity in early, post-independence Haitian literature at times generates an exhilarating sense of freedom - the thrill of exploring in full and pushing to its conceptual limits the new entity that Haiti was - but also a tendency to retreat from that same freedom and to at times neglect or deny fundamental, and especially 'African', aspects of Haitian culture. Haiti's early intellectuals and authors seemed to hesitate before accepting the modern, hybrid nature of their culture, its religion and associated rhythms, which is ironic as Vodou was and is surely the most conspicuous example of Haiti's creolized

4 As Nick Nesbitt says, 'Two of the processes that came to distinguish the Twentieth Century were invented in Haiti: decolonization and neo-colonialism' (Nesbitt, 2005: 6). 
culture. Vodou is essentially a distinctly modern phenomenon, a new entity created out of the meeting of diverse Amerindian, African and European cultural and metaphysical systems. It appears in effect that Vodou, far from being embraced by Haitian intellectuals as a sign of their unique, creolized, modern and rhythmic culture, became associated with a kind of internal otherness, and a sign of the unresolved conflicts and contradictions between the nation's urban, light-skinned elite and the black rural peasantry.

This internal cultural dualism began to be revised during the American occupation of 1915-34. Jean Price-Mars's work profoundly influenced, indeed, revolutionized, Haitian intellectualism across every discipline; as he put it himself, his work led to a 'révolution de l'esprit' [spiritual revolution] (Price-Mars, 1959: 44). Artists and intellectuals from various fields - poets, novelists, historians, painters, musicians, architects, sculptors - turned towards indigenous sources, inspired by the historic or prehistoric past, while sociologists and linguists reconsidered Haitian monuments, mores and language to explain and define what was particular and unique about the Haitian way of life. Importantly, too, new research on Vodou legitimized the religion, and brought it into the intellectual sphere as never before (ibid.: 44-45). As René Depestre states, Price-Mars's Ainsi parla l'oncle was a veritable 'déclaration d'identité' [declaration of identity] for black Haitians, an attempt to refigure Haitian culture on its own terms, which invited occupied Haiti to 'se rafraîchir dans le terreau fécondant de ses origines' [refresh itself in the fertile compost of its origins] (Depestre, 1998: 33, 43). The American occupation revitalized the literature of resistance in Haiti, and the repetitive, 'African' rhythmicity of popular music and religion, long a neglected element of national culture, was incorporated into poetry as never before, and was instrumental in imagining a future free from the restrictions and conflicts of the past. In effect, the Creole musical culture was appropriated by elite intellectuals in an attempt to infuse their written texts with some of the rhythmic energy of popular music. Although such an act of cross-cultural and cross-generic appropriation inevitably involves translation and modification, Haitian elite authors seemed in no doubt that they could capture in written works the sounds and rhythms of the masses.

Newly reinvigorated, Haitian poetry broke free from the more fixed forms of the past, and rhythms and repetitions became integral, conspicuous aspects of the new, freer and more irregular poetics. Poems became hybrid, creolized objects as French-inspired prosody gave way to a more markedly rhythmic, 'African' style. Indigenist poets often drew on popular, African elements - chiefly rhythmic music, the drum and Vodou - to construct a 
new, future-oriented discourse that fused race issues with a Marxist interest in class liberation. ${ }^{5}$

The best-known literary text of Haitian Marxist indigenism is not, however, a poem, but Jacques Roumain's peasant novel Gouverneurs de la rosée (1944), a work that presents the returning exile Manuel as the saviour of a divided rural community, who preaches communal action and cooperation to the fatalistic peasants. Like many indigenist intellectuals, Roumain's interest in Africa and Haitian peasant culture (and their associated rhythms) had grown over time, and had gradually supplanted his early focus on non-racialized issues of poetics and politics. In contrast to his earlier prose fiction, Gouverneurs de la rosée focuses almost exclusively on rural Haiti, and on peasant culture. In this work, the hero Manuel's life is sacrificed in order for the community to reunite and return to its previous, idyllic state of pastoral harmony, an idealized anterior world characterized by proto-communist work systems and Africanized cultural practices, of which rhythms, in work and in music, are an integral part. The organic, rhythmic connections between the people, the land, work and the drum are established early in the novel, when Manuel's father Bienaimé recalls the days of the coumbite, the collective, African-derived work system, which stands in sharp contrast to the impoverished, fatalistic present. Bienaimé's memory of the coumbite includes a vivid recollection of the role of the simidor, the drummer who beats out the rhythms to which the workers sing their work songs and raise their hoes 'd'un seul coup' [in one single sweep] (Roumain, 1944: 18). As Bienaimé recalls, the 'pulsations précipitées' [rapid pulsations] of the drum course through the workers 'comme un sang plus ardent' [like a more ardent blood] (ibid.). The rhythms of Roumain's prose mimic those of the drum and the workers, who are taken over, almost possessed, by the rhythm: 'Une circulation rythmique s'établissait entre le cœur battant du tambour et les mouvements des hommes: le rythme était comme un flux puissant qui les pénétrait jusqu'au profond de leurs artères et nourrissait leurs muscles d'une vigueur renouvelée' [A rhythmic circulation established itself between the beating heart of the drum and the movements of the men: the rhythm was like a powerful flow that penetrated them right to the depths of their arteries and nourished their muscles with a renewed vigour] (ibid.: 19-20). Significantly, Roumain celebrates the practical, utilitarian role of rhythm in bonding workers and promoting group labour; if the workers are 'possessed' by rhythm it is for materially useful, tangible ends. In an important sense, too, it is the rhythmic, reciprocal sharing of work and the synchronization of efforts that create the community in the novel; to work together is effectively

5 For examples of this new rhythmic poetry, see Munro, 2010: 64-68. 
'épouser une pulsation collective, vibrer à l'unisson, communier en un même chant' [to espouse a collective pulsation, to vibrate in unison, to be united in a shared chant] (Bona, 2004). ${ }^{6}$

Roumain's novel is thus sensitive to the ways in which rhythm continued to structure peasant life long after the revolution and the pressing need to use rhythm on the plantations as a means of bringing together the ethnically diverse, culturally fragmented slaves. In the post-revolution period, rhythm, in the form of work songs, drums and the repetitive movements of people and their work tools, in effect helped people get back to working the land, the site of their previous forced labour. Collective, rhythmic work came to be organized by 'Sociétés de travail', or work societies, the principal attribute of which were the orchestras of four or five members playing the drum or bamboo trumpets as the work was carried out. Each society was distinguished by the kind of instruments played and the drum rhythms they preferred (Métraux, 1960: 33). In this way, rhythm, work and social organization were inextricably linked in post-independence Haiti. For the new Haitian state, this rhythmic counter-structure posed a threat to the rigid social and work organization that it sought to impose in the former plantations. For Alexandre Pétion, in particular, whose plans to reinvigorate the plantation system relied on the supply of a compliant, docile workforce, the societies were particularly troubling. In effect, the conflict between the state and the autonomous working societies turned around rhythm: who was to have the power to impose the rhythm of work - the state or the workers themselves? In postcolonial Haiti, as in other places, the 'master of rhythm' was the master of work (Barthélemy, 2000: 165-66). Rhythm had been a supplement to slave life, and had become, as in Roumain's novel, the motor of a model of self-sufficient labour generated by the people and which operated outside the control of the state. ${ }^{7}$

While Roumain evokes and promotes the rhythm-centred work of the peasants, he is more ambivalent about rhythm's role in Vodou possession. Manuel does participate in the ethnographically detailed Vodou ceremony that is held to celebrate his return, but this kind of rhythmic possession is ultimately dismissed as a waste of energy. Manuel says that he danced willingly at the ceremony, took his pleasure and responded to the drums 'en tant que nègre véridique' [as a real black man], but for him Vodou is finally 'des bêtises' [foolishness] and 'inutile' [useless] (Roumain, 1944:

6 Rhythm may be seen as an element in Roumain's construction of an 'organic' community in the novel. For more on the organic nature of the community, see Britton, 2006.

7 On the relationship between work and rhythm, see Lefebvre, 1992: 100. 
96). For Roumain, therefore, rhythm was of interest as an aspect of Haiti's ethnographic reality, and as a means of structuring work and society. It was, moreover, as for many Haitian indigenist intellectuals, a source of memory, and a recurring, insistent counterpoint to the educated elite's complacently adopted francophilia. Despite Roumain's misgivings about the practical benefits of Vodou, he and indigenism in general had recognized, and to some extent co-opted, popular culture as valid, politically potent elements of Haitian culture. The drum and rhythm were perhaps the primary elements of this culture, echoes of a past that had been forgotten by the urban elite, but which had continued to evolve dynamically in harmony with the changing lives of the Haitian masses.

Roumain was, in effect, something like James Brown and many others across the circum-Caribbean, using rhythm to transcend the present and imagine a different kind of society, one that retained elements of the past, but was still in essence an unrealized reality and a time to come. Roumain was creating his own rhythm revolution in terms of literary style, too, as his compatriot Lyonel Trouillot would write much later: 'Since Gouverneurs de la rosée (without this being an obligation, a master text, or a model, everyone being free to construct their own grammar) the phrasing of certain Haitian novelists has had hips, an almost carnal swinging quality' (Trouillot, 2010: 182).

\section{Rhythm, Everyday Existence and Creolization}

Rhythm is therefore often evoked in Haitian culture at times of crisis, stagnation or uncertainty and as a means of imagining a future freed from the restrictions of the present. Much the same can be said of the broader Caribbean, too. The crises need not be on a societal or national level, but can be individual moments of uncertainty and anxiety. A striking example of such a rhythm-induced individual moment occurs in Joseph Zobel's classic novel La Rue cases-nègres (1950) when the young protagonist José's repetitive routine of school and chores is dramatically altered and enlivened by the arrival of a travelling fair. The fair seems to offer José and the community a chance to escape the harsh rhythms of the plantation they live and work on. José's personal crisis - his poverty and the realization that he cannot have access to the rhythmic pleasures of the fair - is related to the broader historical situation and his awareness that his community's way of life has changed little since the end of slavery. Initially dismayed by his lack of money, José is receptive, as he is throughout the novel, to the sounds of recreation, and becomes enchanted by the rhythms of the carousel. Indeed, as he says, the whole village is 'enthralled' by the orchestra that accompanies 
the carousel. From a distance, all he can hear of the music is the beat of the tom-tom that scans the waltz to which the carousel rhythmically turns. But the beat has an entrancing effect on him and his senses - he simultaneously listens to and 'feels' the rhythm - and he is drawn irresistibly to its source:

c'était comme autant de coups de gong invitant à la joie, autant de coups frappés à mes entrailles, et qui, à la douleur de ma situation alarmante et quasi désespérée quand l'argent n'arrivait pas, et qui, à tout instant, comme une voix enjôleuse et une force irrésistible et perverse, nous ramenait tous sur la place du marché. ${ }^{8}$ (Zobel, 1950: 150)

In this instance, rhythm works as a palliative for José's despair. What is interesting is that the rhythm does not work against the pain, but with and to it, almost as if it is on a common frequency that does not deny the pain but finds its beat as it were and falls into its rhythm. Similarly, too, discrete personal subjectivity in a sense collapses - the 'we' subsumes the 'I' - and the collective supersedes the individual. The carousel's rhythmic music has, moreover, a visceral, bodily effect that only intensifies as José is drawn closer to it: 'A mesure qu'on approchait se révélaient les baguettes rythmiques, le shasha, et, au moment même où apparaissait le toit pivotant et bordant d'oriflammes, le son de la clarinette éclatait dans ma tête, dans mon ventre, me prenait, m'attirait plus vite.' [As we approached the rhythmic drumsticks, the shasha appeared and at the very moment the revolving, banner-trimmed roof appeared, the sound of the clarinet burst in my head, in my stomach, took me, pulled me ever more quickly] (Zobel, 1950: 150).

In this way the rhythmic sounds of the carousel are complemented and emphasized by the swirling movements of the carousel so that José, in a distinctly filmic scene, feels at once the aural and visual effects in one irresistible rhythmic ensemble. This polyrhythmic effect is narrated in prose that omits periods and gradually reduces the length of clauses to form one long, rhythmic sentence:

Alors, à voir des femmes qui, sous l'effet de la musique, marchaient en roulant des épaules et secouant des fesses, des hommes dont les reins s'imprimaient d'un roulis étrange, à voir de près tourner les chevaux de bois montés d'enfants en robes blanches et à nouds rouges, d'enfants en costumes neufs, d'enfants à chaussures vernies, d'enfants noirs, aux

8 'It was like so many beats of a gong inviting us to its joy, so many beats struck in my guts and which, to the pain of my alarming, almost desperate, penniless situation, and which at any moment, like a coaxing, seducing voice and an irresistible and perverse force, drew us all to the market square.' 
rires clairs et chauds, et sentir au fond de moi la convulsion des coups de tam-tam, forts et doux comme un sang épais, je demeurais dans une sorte de transe d'où j'étais long à revenir. '(Zobel, 1950: 150)

From his perspective as a spectator the carousel swirls and entrances in colour and sound, so that the identity of the children on the horses becomes indistinct, lost, at least for the duration of the ride. Similarly, the rhythmic sounds and motions seem to alter the experience of time, as the children are transported to a state of being outside, or perhaps rather, inside time and space. The penniless José is desperate, however, to switch from spectator to participant, to be the one with the blurred identity. As he realizes, from the perspective of the participant on the horses, turning at great speed to the beat of the tom-tom, it is impossible to see the spectator, while on the outside the crowd could not 'distinguer ceux qui tournaient' [distinguish those who turned] (Zobel, 1950: 151). In other words, it is only from the seat on the horses that identity is completely, albeit momentarily, lost; or, indeed, that it is found, released from the gaze of the community, and from its strictures and hardships. The image of José standing on the outside in his school uniform on the threshold of the absolute liberty and surrender of identity that the carousel offers is a poignant one, and suggests something of his split subjectivity and the difficulty he has and will have later in the novel of reconciling the world of education and respectability with his instincts for escape and rhythmic release. ${ }^{10}$ As such, the rhythms of the carousel portend the future, though the future is not here related to a clear sense of liberation or freedom, but to a more ambivalent time to come and a compromised, partial liberation. It is perhaps significant that the carousel is an object of European origin, in that its rhythms do not evoke a leap into the future, but a circular movement, time and experience turning repetitively on an axis. This seems appropriate more generally, for just as José's rhythmic escape

9 'Then, seeing the women who, under the effect of the music walked rolling their shoulders and shaking their behinds, the men whose hips rolled strangely, seeing up close the carousel horses turning with children in white dresses and red bows, children in new suits, children in polished shoes, black children, laughing clearly and passionately, and feeling in the very depths of me the convulsion of the tom-tom beats, hard and soft like a thick blood, I remained in a kind of trance that lasted for a long time.'

10 Significantly, too, it is only when his friend Jojo arrives with his 100 cent note that José is finally able to ride the carousel and to experience the 'griserie libératrice de mes refoulements puérils' [liberating intoxication from my childhood repression] (Zobel, 1950: 153); access to money and higher social status are tacitly confirmed as the most likely and enduring means of liberation. 
is compromised, temporary and uncertain, so the future that Martinique has known since Zobel wrote his novel in 1950 has been one of continued attachment to France and often ambivalent accommodation of metropolitan culture. José's rhythmic interactions seem to sense this future, incomplete freedom and the difficulties of attaining full liberation on both the personal and societal levels.

Nevertheless, this remarkable sequence presents a striking example of rhythm as a very real force that invites and seduces the poorest in particular into an intimate relationship with it and a different state of consciousness that offers a kind of escape and healing, however temporary. In a sense, Zobel comes close to suggesting, like Aimé Césaire (and others) did, that rhythm is an essential aspect of the black man, something innate, 'fort [...] et doux comme un sang épais' [strong and soft like a thick blood], as José says (ibid.: 150). And yet, however much the people are drawn irresistibly to the rhythm, in grounding the event in the everyday existence of the village, Zobel is able to avoid the questionable mysticism of Césaire's poetry and to present the phenomenon in more ethnographic, phenomenological terms. If the people do have a visceral connection to rhythm, it is grounded in everyday existence and therefore has a function that can be to some extent explained with reference to the hardships of that existence and to the way that rhythm has historically offered escape and healing to the Martinican poor.

Zobel's fairground rhythms are, moreover, creolized in that they mix the African tom-toms with the beats and melodies of the carousel orchestra's European instruments, creating a hybrid musicality that reflects the broader cultural fusions that are truer legacies and reflections of Martinique's complex history than the more monolithic drumming that is evoked in Césaire's work, for example. This is significant, as rhythm has been one of the primary vectors of creolization in the Caribbean and the broader plantation world. It was through rhythm, dance and music that the earliest cultural encounters between Africans and Europeans were mediated in the circum-Caribbean, even in the darkest days of slavery. In Trinidad, for example, despite all the fear and suspicion that separated the various social groups, there was also, just as in colonial Saint-Domingue and other Caribbean sites, mutual fascination and often disavowed identification across race and class barriers. Role reversals and parodies - central aspects of post-Emancipation Carnival - demonstrate the complex exchange of conceptions and misconceptions of the other that in turn destabilized fixed dualistic notions of identity, which were strategically promoted by the colonial administration and its various organs, including the Church. In the pre-Emancipation period, contemporary reports speak of slaves calling at the plantation house at Christmas, receiving their seasonal 'allowances' and then flouring 'each other's black faces and 
curly hair', crying out, 'look at he white face! And he white wig!' (quoted in Cowley, 1996: 17). It was at these times of merriment, and of breaks in the routine of plantation work, that such mutual parodies took place. Similarly, during Carnival season in the early to mid-nineteenth century, the white (French Creole) plantocracy themselves parodied the slaves' celebrations of Canboulay (from the French cannes brulees, or burnt canes), the feast that marked the end of one cycle of plantation work, and which became associated with Carnival celebrations in Trinidad. ${ }^{11}$ When a fire broke out on an estate, neighbouring bands of nègres jardins or field slaves were called to put the fire out, and to save what cane they could, working to the beat of their drums. ${ }^{12}$ The origins of Canboulay lay in the early part of the nineteenth century, at which time the elite of the society took an active part in all aspects of Carnival. According to contemporary accounts, the upper-class white parody of Canboulay contained all of the essential elements of the slaves' celebration: the white women would dress up in mulatresse style, the men in nègre jardin mode, and together they would form separate bands 'representing the camps of different Estates, and with torches and drums to represent what did actually take place on the estates when a fire occurred in a plantation' (quoted in Pearse, 1956: 182). The rhythmic aspects of the whites' parody are further suggested in an observer's recollection of this 'take off' of slave life, and his memory of whites dressed as 'slaves stamping in time and singing a rude refrain, to a small negro-drum'. In addition, the white elite mimicked the slaves' rhythmic drum dances, such as the bamboula, the belair, the calinda and the ghouba. The drum and rhythm have been constant elements in these cross-cultural exchanges. In all, these transracial parodies indicate that whereas work and social structures carefully delineated and perpetuated categories of race and class, in these crucial cultural, rhythmic exchanges these positions were far more fluid, and far less entrenched than one might have expected them to be (see Cowley, 1996: 21$) \cdot{ }^{13}$ It was rhythm that opened up the society, however imperfectly and fleetingly, and which,

11 As Cowley points out, there were direct equivalents of Canboulay in Carriacou and St Lucia, and possibly also in Martinique and Guadeloupe (Cowley, 1996: 233).

12 Jacob D. Elder argues that Canboulay can be examined in four basic ways: as a 'Black resistance ceremony'; a 'recreational pageantry of Africans'; an 'anti-Catholic celebration of freedom from slavery and the origin of the present Carnival'; and as a 'popular street theatre, exhibiting African-style dance, theatre, and music' (Elder, 2004: 49).

13 Stephen Stuempfle also emphasizes 'intercultural exchange' as a salient aspect of early Trinidadian culture (Stuempfle, 1995: 14). 
always turned towards the future, was the most persistent means by which social hierarchies were destabilized, and finally overturned.

In effect, these rhythmic exchanges occurred to lesser or greater degrees across the plantation world. In each case, these were future-oriented performances, which staged a possible society to come, one in which were ended or otherwise lessened the inequities and indignities of the plantation. It was through rhythm that this future world was first imagined. But rhythm was more than a mere means of firing the imagination; as the era of slavery ended, and a new set of challenges presented themselves, rhythm (in songs, dance, poetry, fiction) played a dynamic role in effecting change, in expressing lower-class social aspirations and the desire for a world remade. Rhythm was a force for unification; no 'race' either owned it or was immune to its effects. In every American territory shaped by the processes of creolization, rhythm has been an ever-present (if overlooked and under-theorized) element in imagining and bringing into being the new hybrid societies that constitute the circum-Caribbean world. And if rhythm remains a significant cultural and social force in this region, it is because the processes of change are ongoing, the societies are still being made, and the people are still - as James Brown was - 'fightin' the future'.

\section{Works Cited}

Barthélemy, Gérard. 2000. Créoles - Bossales: conflit en Haïti. Petit-Bourg: Ibis rouge.

Bona, Dénètem Touam. 2004. 'Negros Cimarrones 2'. Africultures. <http:// www.africultures.com/php/index.php?nav=article\&no=3696>. Consulted 11 December 2011.

Britton, Celia M. 2006. "Common Being” and Organic Community in Jacques Roumain's Gouverneurs de la rosée'. Research in African Literatures 37.2: 164-75.

Brown, James. 1991. 'Introduction'. Album liner notes to James Brown, Star Time. Polygram 849 108-2.

-. 2005. I Feel Good: A Memoir of a Life of Soul. New York: New American Library.

Cowley, John. 1996. Carnival, Canboulay, and Calypso: Traditions in the Making. Cambridge University Press.

Danielsen, Anne. 2006. Presence and Pleasure: The Funk Grooves of James Brown and Parliament. Middletown, CT: Wesleyan University Press.

Dash, J. Michael. 1998. The Other America: Caribbean Literature in a New World Context. Charlottesville and London: University of Virginia Press.

Depestre, René. 1998. Ainsi parle le fleuve noir. Paris: Paroles d'aube. 
Elder, Jacob D. 2004. 'Cannes Brûlées'. Culture in Action - The Trinidad Experience. Ed. by Milla Cozart Riggio. New York: Routledge: 48-52.

Glissant, Édouard. 1989. Caribbean Discourse: Selected Essays. Trans. by J. Michael Dash. Charlottesville and London: University of Virginia Press.

—. 2000 [1999]. Faulkner, Mississippi. Trans. by Barbara B. Lewis and Thomas C. Spear. Chicago, IL and London: University of Chicago Press.

Guralnick, Peter. 2002. Sweet Soul Music: Rhythm and Blues and the Southern Dream of Freedom. Edinburgh: Mojo Books.

Lefebvre, Henry. 1992. Eléments de rythmanalyse. Paris: Éditions Syllepse.

Marsh, Dave. 1989. The Heart of Rock and Soul: The 1001 Greatest Singles Ever Made. Harmondsworth and New York: Penguin.

Métraux, Alfred. 1958. Le Vaudou haïtien. Paris: Gallimard. English translation by Peter Leyngel, Haiti: Black Peasants and their Religion, 1960. London: Harrap.

Munro, Martin. 2010. Different Drummers: Rhythm and Race in the Americas. Berkeley: University of California Press.

Nesbitt, Nick. 2005. 'The Idea of 1804'. Yale French Studies 107: 6-38.

Nicholls, David. 1981. From Dessalines to Duvalier: Race, Colour, and National Independence in Haiti. Cambridge University Press.

Pearse, Andrew. 1956. 'Carnival in Nineteenth Century Trinidad'. Caribbean Quarterly 4.2-4.3: 175-93.

Price-Mars, Jean. 1959. De Saint-Domingue à Haïti: essai sur la culture, les arts et la littérature. Paris: Présence africaine.

Rose, Cynthia. 1990. Living in America: The Soul Saga of James Brown. London: Serpent's Tail.

Roumain, Jacques. 1944. Gouverneurs de la rosée. Paris: Éditeurs français réunis. Stuempfle, Stephen. 1995. The Steelband Movement: The Forging of a National Art in Trinidad and Tobago. Bridgetown, Barbados and Kingston, Jamaica: The Press, University of the West Indies.

Trouillot, Lyonel. 2010. 'To the Text'. In Martin Munro (ed.), Edwidge Danticat: A Reader's Guide. Charlottesville and London: University of Virginia Press: 180-83.

Vincent, Rickey. 1996. Funk: The Music, the People, and the Rhythm of the One. New York: St Martin's Griffin.

Werner, Craig. 2006. A Change is Gonna Come: Music, Race, and the Soul of America. Ann Arbor: University of Michigan Press.

White, Cliff, and Harry Weinger. 1991. 'Are You Ready For Star Time?'. Album liner notes to James Brown, Star Time. Polygram 849 108-2.

Zobel, Joseph. 1950. La Rue cases-nègres. Paris: Présence africaine. 


\title{
Leaving the South: Frantz Fanon, Modern Jazz and the Rejection of Négritude
}

\author{
Jeremy F. Lane
}

In his biography of Frantz Fanon, David Macey is somewhat dismissive of the scattered allusions to jazz Fanon makes throughout his work. Thus, according to Macey, the 'parody of the négritude vision of Louis Armstrong's music' in Peau noire, masques blancs (1952) proves that Fanon knew little about the music itself and was interested primarily, if not exclusively, in its sociological significance (Macey, 2000: 124). The promotion of modern jazz, in Les Damnés de la terre (1961), as a model for the 'national culture' of a newly independent Algeria, meanwhile, was simply 'not at all pertinent' to Algeria (ibid.: 378).

This chapter will argue that Macey has misunderstood and underestimated the significance of Fanon's various allusions to jazz. Further, his attempts to adjudicate on the question of precisely which cultural forms were or were not 'pertinent' to any discussion of the Algerian situation appear to rely upon a set of unquestioned assumptions about ethnic or national identity, the particular cultural forms appropriate to that identity and the specified geographical locations to which those cultural forms might hence be considered 'pertinent'. In this sense, his rather dismissive comments regarding Fanon's interest in jazz might be seen as broadly analogous to Françoise Vergès's critique of what she sees as Fanon's 'disavowal' of the 'reality' of his Creole identity in favour of a reinvention of his 'filiation' and 'symbolic ancestry in Algeria' (Vergès, 1997: 579). Where Macey criticizes the impertinence of Fanon's attempts to relate modern jazz to the Algerian situation, Vergès criticizes the impropriety of his pretence to an Algerian 'filiation' that can only, in her view, be based on a 'disavowal' of his true 
identity. Both critics seem to possess a strong and rather sententious sense that agents and cultural forms alike have their rightful place or true identity and should stick to that place or identity. Implicit in Macey's and Vergès's remarks, then, is the call for Fanon to be brought back into line, to acknowledge his true identity, and discuss cultural forms which express that identity only in relation to the specified geographical location from which they are taken to originate and to whose political or cultural dilemmas they remain, exclusively, pertinent.

What lies behind all of this appears to be certain fundamentally Romantic assumptions about the organic relationships between ethnic identity, bounded geographical location and their associated forms of cultural and linguistic expression. Ironically, as this article will seek to demonstrate, Fanon's scattered allusions to jazz show him attempting precisely to question and reformulate each of those Romantic assumptions. In Fanon's case, the most obvious manifestation of the pitfalls attendant upon such organic and essentialized notions of black identity was to be found in Senghor's conception of négritude. In his early essays and poems, Senghor had attributed a very particular role to jazz, claiming it to be an important expression of négritude: that is to say, of an essentialized nègre identity, ${ }^{1}$ rooted in the unchanging rhythms of an organic rural community, of which West Africa was the archetype and the American South its faithful reproduction in the New World. Fanon's allusions to jazz form an integral part of his critique of Senghor's négritude and, as such, involve him seeking to uncouple jazz's potential cultural and political significance from any organic links the music might be assumed to possess either to essential racial identity or to its putative geographical place of origin in the American South.

Whilst it is true, then, that Fanon's allusions to jazz throughout his work are both brief and sporadic, it is important not to underestimate their significance. Through these scattered allusions Fanon does not simply disavow all questions of ethnic identity, however that identity might be understood to relate to the interlinked locations of Africa, the American South and the Francophone Caribbean. Rather he seeks to challenge and reformulate certain enduring, essentially Romantic assumptions about the organic links between geographical location, ethnic identity, cultural expression and political agency. In order to understand quite what is at stake here, it will

1 Since it covers a range of connotations, which are not adequately conveyed by the English 'black' or 'negro', the French term nègre will be retained throughout this chapter. For a detailed analysis of nègre's many meanings, and a justification for retaining the original French term, see Edwards, 2003. 
be necessary to return to the apparently well-worn topic of Fanon's critique of Senghor's négritude, focusing on the dispute over the significance of jazz that is one of its central, but henceforth largely overlooked, elements.

\section{Jazz, Négritude and the American South}

Fanon's best-known and most commented upon criticisms of Senghor's négritude are contained in his 1952 study Peau noire, masques blancs. As Robert Bernasconi points out (Bernasconi 2002), Fanon's critique comprises two interrelated elements. First, he takes issue with Senghor's account, in the 1939 essay 'Ce que l'homme noir apporte', of black identity as comprising an inherent rhythmic sensibility, an essential spirituality and an organic relationship with the natural and social worlds. This account, according to Fanon, represents an essentialist and primitivist conception of black identity, which risks denying black people any capacity for rational thought or historical agency (Fanon, 1952: 98-104). Secondly, Fanon questions Senghor's emphasis on delving into the past, on seeking in the glories of pre-colonial West Africa the key to black identity in the twentieth century. This, too, he argues, represents a kind of essentialism, locking black people into a mythologized past to the detriment of any acknowledgement of their role as active agents in the modern world. As Fanon puts it,

Le problème envisagé ici se situe dans la temporalité. Seront désaliénés Nègres et Blancs qui auront refusé de se laisser enfermer dans la Tour substantialisée du Passé. Pour beaucoup d'autres nègres la désaliénation naîtra, par ailleurs, du refus de tenir l'actualité pour définitive. [...] En aucune façon je ne dois m'attacher à faire revivre une civilisation nègre injustement méconnue. Je ne me fais pas l'homme d'aucun passé. Je ne veux pas chanter le passé aux dépens de mon présent et de mon avenir. ${ }^{2}$ (Fanon, 1952: 183)

As Bernasconi puts it, what this means is that Fanon is unwilling to look to the past of peoples of colour for a solution or for his "original

2 'The problem envisaged here relates to temporality. The Nègres and the Whites who have refused to allow themselves to be enclosed in the substantialised Tower of the Past are the ones who will be disalienated. Moreover, for many other Negres, disalienation will arise from their refusal to accept the present as definitive. [...] In no way should I dedicate myself to reviving an unjustly unrecognised nègre civilisation. I will not make of myself a man of any past. I do not want to exalt the past at the expense of my present and my future' (Fanon, 1986: 226; translation modified). 
calling"' (Bernasconi, 2002: 73). However, Bernasconi neglects to consider the significance of the fact that this passage is immediately preceded by one in which Fanon recounts an anecdote relating directly to jazz. Indeed, the 'problem envisaged' in the quotation above is exemplified, for Fanon, by a particular interpretation of jazz.

Fanon tells of being invited by the Association lyonnaise des Etudiants de la France d'outre-mer to deliver a speech refuting the claims of a white commentator who had claimed that 'la musique de jazz' represented 'une irruption du cannibalisme dans le monde moderne' [jazz music represented an irruption of cannibalism in the modern world]. Fanon explains that he rejected 'les prémices de l'interlocuteur' [the premises of my interlocutor], choosing not 'à prendre position pour la musique noire contre la musique blanche, mais à aider mon frère à abandonner une attitude qui n'avait rien de bénéfique' [to take position in favour of black music against white music, but to help my brother to abandon an attitude that was in no way helpful] (Fanon, 1952: 183 [1986: 226]). He concludes that the 'problem envisaged here relates to temporality', before going on, as we have seen, to argue that this same problem of temporality is manifest in the négritude project of 'reviving an unjustly unrecognised nègre civilisation'. Fanon's point is that the white racist's denunciation of jazz as a form of modern cannibalism and négritude's mythologization of a lost nègre civilization are two sides of the same primitivist coin. He suggests that the proper response to this is not to celebrate the authenticity of black musical forms in opposition to their white equivalents but to abandon that binary opposition altogether as being 'in no way helpful'.

The analogy Fanon draws in Peau noire, masques blancs between négritude, on the one hand, and primitivist interpretations of jazz, on the other, becomes more understandable when we recall the important role Senghor accords to jazz in his early essay 'Ce que l'homme noir apporte'. Rightly considered a seminal statement of Senghor's négritude, the work has elicited much commentary as a result. However, the specific role Senghor attributes to jazz in this essay has, again, been largely overlooked, as has the extent to which Fanon's later critique of Senghor's négritude turns on a disagreement over the precise cultural significance of jazz.

Senghor opens 'Ce que l'homme noir apporte' by citing the German anthropologist Leo Frobenius in support of his contention that there exists a unified 'culture nègre', which was born in Africa and which, 'émigrée en Amérique, est restée intacte dans son style' [having emigrated to America, has remained intact in its style] (Senghor, 1939: 22-23). ${ }^{3}$ He argues that

\footnotetext{
3 This and all subsequent quotations from this source are my translations.
} 
this 'nègre culture' embodies a series of fundamental values which have been lost in an excessively rationalistic and materialistic West - a spiritual transcendence, a sensitivity to the rhythms of the natural world, organic collectivist social and familial structures, unalienated forms of agricultural and artisanal labour. In short, Senghor suggests that everything that is missing in contemporary Western societies can be found in the traditional structures and practices of West Africa or, in their transplanted form, on the plantations of the American South.

Thus Senghor maintains that the 'âme nègre reste obstinément paysanne' [the nègre soul remains obstinately peasant] and this explains why, 'aux États-Unis, les ouvriers du Nord [...] ont la nostalgie des plantations du Sud, où leurs frères vivent en serfs' [in the United States, the workers of the North [...] are nostalgic for the plantations of the South, where their brothers live like serfs] (Senghor, 1939: 31). Such nostalgia reflects the fact that agricultural labour, particularly as practised in rural West Africa, epitomizes honest, 'noble' toil, securing the joys contingent upon an organic relationship with the soil and with the rhythms of nature itself, joys severely lacking from mechanized labour in the West.

C'est que le travail de la terre permet l'accord de l'Homme et de la 'création', qui est au cœur du problème humaniste; qu'il se fait au rythme du monde: rythme point mécanique, qui est libre et vivant; celui du jour et de la nuit, des saisons qui sont deux en Afrique, de la plante qui pousse et qui meurt. Et le Nègre, se sentant à l'unisson de l'univers, rythme son travail par le chant et le tam-tam. Travail nègre, rythme, joie nègre qui se libère par le travail et se libère du travail. ${ }^{4}$ (Senghor, 1939: 31)

Implicit in Senghor's depiction of the rhythms of nègre labour being modelled on and accompanied by the rhythms of song and percussion is the notion that, in West African society, culture has remained integrated into the praxis of everyday life, rather than splitting off to occupy an autonomous cultural sphere, where it might atrophy or degenerate, as in the West. Nègre culture has retained this integrated role 'chez les Nègres occidentalisés,

4 "Working the land allows for the unity between Man and "creation" that is at the heart of the humanist problem. It allows him to adapt to the rhythm of the world, a rhythm which is in no way mechanical, which is free and alive; the rhythm of the day and the night, the rhythm of the seasons, of which there are two in Africa, the rhythm of the plant which grows and dies. And the Nègre, feeling himself at one with the universe, paces his work by the song and the tom-tom. Nègre work, nègre rhythm, nègre joy which liberates itself by work and liberates itself from work.' 
américanisés' [amongst Westernized, Americanized Nègres]. Like sculpture and dance, 'nègre music' is 'enracinée dans le sol nourricier, [...] chargée des rythmes, des sons et des bruits de la Terre' [rooted in the nourishing earth, [...] laden with the rhythms, sounds and noises of the Earth] and, as such, could bring 'la sève nécessaire à la musique occidentale appauvrie, car basée et perpétuée sur des règles arbitraires, surtout trop étroites' [the sap necessary to Western music, which has become impoverished through being based on and perpetuated through arbitrary and, above all, too narrow rules] (Senghor, 1939: 36). Such music owes its regenerative role, first, to its organic rhythms, rhythms expressed in Africa in 'le tam-tam, voire le battement des mains' [toms-toms, or even the clapping of hands] and in America in 'ce que les Américains appellent swing' [what the Americans call swing] (ibid.: 37). The second contribution nègre music could make to the regeneration of the West is most clearly expressed in the characteristic style of 'hot jazz' performance. It is here, Senghor claims, that 'les Afro-Américains sont restés le plus près des sources. C'est affaire de style avant tout: d'âme' [the Afro-Americans have remained closest to the source. It is a matter of style above all: of soul] (ibid.). Here Senghor turns to the work of the contemporary French jazz critic, Hugues Panassié, whose 1934 study, Le Jazz hot, he credits with having 'mis en pleine lumière les apports nègres dans le jazz hot, dont le caractère fondamental est dans l'interprétation' [cast full light on the nègre contributions in hot jazz, whose fundamental characteristic is in performance]. Panassié had explained the ability of the 'hot' musician to endow notes with an expressive quality which communicated his whole personality. As Senghor puts it, glossing Panassié's analysis: 'C'est cette façon particulière d'entourer la note, le son, d'un halo de chair et de sang, qui le fait paraître si trouble et si troublant; cette façon "naïve" de traduire, par la voix la plus charnelle, la spiritualité la plus secrète' [It is this particular manner of surrounding the note, the sound, with a halo of flesh and blood, which makes it appear so troubled and so troubling; this 'naive' manner of communicating, by means of the most carnal of voices, the most secret form of spirituality] (ibid.: 38).

\section{Jazz, Panassié and the French Extreme Right}

Senghor's account of the relationship between jazz and négritude in 'Ce que l'homme noir apporte' would thus seem to epitomize that organic conception of the links between ethnic identity, geographical location and cultural expression we discussed in the introduction to this chapter. If that organic conception, in itself, risks reproducing a certain essentialism and primitivism, Senghor's reliance on the jazz criticism of Hugues Panassié is 
fraught with dangers of a more directly political nature yet. In the 1930s, Panassié was the best-known jazz critic in France and one of the most influential jazz critics anywhere in the world. A founding member of the French jazz appreciation society, the Hot Club de France, his study Le Jazz hot had been rapidly translated into English for an American readership and has subsequently been acknowledged as a founding text in the emergence of jazz criticism as a serious discipline. However, Panassié remains a highly controversial figure in jazz history and this for two principal reasons. First, he was affiliated with the French extreme right, being a close personal friend and collaborator of a number of jeunes maurrassiens, or young supporters of Charles Maurras, the leader of the extreme right-wing, anti-democratic and rabidly anti-Semitic Action française movement. Indeed, in the course of 1937, Panassié contributed two articles on jazz to the jeune maurrassien newspaper L'Insurgé in which he presented jazz's authenticity, vitality and spontaneity as an antidote to the decadence of the modern industrial and democratic age, seeking thus to champion jazz's possible role in the extreme right's programme of national regeneration (Panassié 1937a; 1937b).

If Panassié's extreme right-wing political affiliations seem problematic, the second reason he remains a controversial figure in jazz criticism reflects his complete refusal to accord modern jazz any musical or aesthetic value whatsoever, rejecting the music as a degraded European by-product of the true essence of traditional jazz, played by black musicians. Already by the late 1930s, Panassié had begun to embrace a racially purist conception of jazz, tinged with his own peculiar version of Catholic spirituality. By the end of the 1930s, Panassié was arguing that blacks and only blacks were capable of playing proper or 'hot' jazz and, as Ludovic Tournès puts it, 'les Noirs deviennent pour lui une sorte de peuple élu et le jazz un moyen de communication avec le divin' [Blacks became for him a sort of chosen people and jazz a means of communicating with the divine] (Tournès, 1999: 56). When the first recordings by bebop artists such as Dizzy Gillespie, Thelonius Monk and Charlie Parker arrived in France after the Liberation, Panassié's aesthetic and racial purism became more extreme still. He published a series of fierce polemics denouncing these practitioners of modern jazz, arguing they performed an excessively intellectual form of the music that had tainted the original freedom and spontaneity of traditional, New Orleans jazz by an over-reliance on harmonic complexities deriving from European music. Jazz, according to Panassié, was originally and essentially a simple, spontaneous, inherently black musical form and, as such, needed to be preserved from the polluting force of a degraded European intellectualism (Panassié, 1959; 1965). Panassié's polemics against modern jazz provoked a schism in the Hot Club de France and the broader field of French jazz criticism, the so-called guerre 
$d u$ jazz, which set Panassié against a generation of mostly younger critics, who sought to defend the value and significance of modern jazz. ${ }^{5}$

It has become conventional amongst commentators on the reception of jazz in France to distinguish between the traditionalist and racially purist conception of jazz Panassié embraced from the late 1930s onwards and the apparently more enlightened, hybrid conception of the music he elaborated in his earlier book of 1934, Le Jazz hot (see, e.g., Tournès, 1999: 53-58, 77-81 or Gennari, 2006: 57-58). Certainly, it is true that Le Jazz hot describes jazz as the product of a process of hybridization between African and European musical styles and traditions. Nonetheless, even that earlier study is marked by a profound ethnocentrism, as all of the African or 'black' elements of that hybrid are ascribed typically primitivist characteristic of natural, simple or untutored spontaneity and carnality, while all of the European or 'white' elements are ascribed 'superior' characteristics of order, intellect and reason (Panassié, 1934). Moreover, in elaborating his jazz aesthetic, Panassié draws heavily on the work of the Catholic philosopher Jacques Maritain, most notably the latter's Art et scolastique (1920). At the time of writing Art et scolastique, Maritain had himself been a member of Action française and the book contains a scathing critique of rationalist, post-Cartesian philosophy, of the 'ferveur nivelleuse' [levelling fervour] of the democratic French Third Republic, and of what Maritain terms 'la spirituelle acéphalie du siècle des lumières' [the spiritual brainlessness of the Enlightenment] (Maritain, 1920: 65-66). Against this degenerate rationalist tradition, Maritain promotes a spiritual conception of the aesthetic which rejects French republican egalitarianism in favour of a recognition of a God-given hierarchy of grace, talents and artistic abilities. In the course of Le Jazz hot, Panassié appropriates this Catholic, spiritual and decidedly anti-egalitarian aesthetic to promote jazz as the privileged expression of natural God-given talents and hence traditional order.

Senghor's interest in Panassié's jazz criticism surely reflected both his own Catholic spirituality and his own fondness for the philosophy of Maritain, a philosophy whose political implications had, by the 1930s, become rather ambiguous. As we have seen, at the time of writing Art et scolastique Maritain was a firm supporter of Charles Maurras and a member of Action française. In 1926, however, Maritain had left Action française, following the Pope's decision to excommunicate Maurras and denounce Action française for its political extremism. By the 1930s, Maritain had allied himself with the broad

5 For a summary of the positions taken by Panassié, see Panassié 1959; 1965. For a detailed refutation of Panassié's position, as well as a statement of the opposing camp's interpretation of modern jazz, see Hodeir, 1954. 
current of French social Catholicism, situated on the centre, or centre-left of the political spectrum, and had begun to elaborate his philosophy of 'integral humanism' as a foil to Maurras's 'integral nationalism' (Maritain, 1936). This current, which embraced the 'personalism' of Emmanuel Mounier alongside Maritain's own 'integral humanism', sought a 'third way' between fascism and communism, while retaining many of the Catholic, anti-rationalist, anti-modern, anti-statist, pro-corporatist ideas that Maritain had shared with Action française in the early 1920s. Its anti-materialism and anti-statism led to an interest in the cultures of France's provinces and colonies, and hence its journals, such as Charpentes and Mounier's Esprit, were happy to publish the first writings by French intellectuals of colour, including Léon Gontran Damas, Aimé Césaire and Senghor himself. A practising Catholic, Senghor possessed a strong religious, philosophical and political affinity to the philosophies of Maritain and Mounier (Wilder, 2005: 244-45). Nonetheless, this current was politically highly ambiguous, its critique of the degeneracy of the modern world remaining amenable to extreme right-wing interpretations and affiliations. This would be strikingly demonstrated in the months immediately following the fall of France in 1940 when Mounier welcomed the end of the Third Republic, declaring in Esprit in November 1940, for example, that 'democracy was a parasite on France', and presenting the Vichy regime as an opportunity to put some of his ideas into practice (Shennan, 1989: 29).

If the dividing line between extreme right-wing and centre-left interpretations of this current of interwar Catholic thought was not always clear-cut, all the evidence suggests that Panassié stood unambiguously at the extreme right wing of that political and philosophical spectrum. Senghor's interest in both Maritain and in Panassié's jazz criticism, by contrast, might seem to be expressions of the centre-left interpretation of that current of interwar French Catholic thought. However, as Mounier's flirtation with the Vichy regime demonstrates, even the centre-left version of such thought could lapse into dangerously conservative, nostalgic and anti-rationalist forms of political thought and practice. This, essentially, was the burden of the critiques which Fanon addressed to Senghor's conception of négritude. As we have already seen, the famous passage of Peau noire, masques blancs in which Fanon rejected négritude's project of 'reviving an unjustly unrecognised nègre civilisation' was prefaced by an anecdote about his response to primitivist interpretations of jazz. This strongly suggested Fanon had a keen awareness of the links between Senghor's négritude and Panassié's jazz criticism. Further confirmation of this would seem to be offered by an earlier passage in Peau noire, masques blancs in which Fanon parodies the primitivist interpretation of jazz in the following terms: 'Je suis Noir, je réalise une fusion totale avec le monde, une compréhension sympathique de la terre; une perte de mon 
moi au cœur du cosmos, et le Blanc, quelque intelligent qu'il soit, ne saurait comprendre [Louis] Armstrong et les chants du Congo' [I am Black, I achieve a total fusion with the world, a sympathetic understanding of the earth, a loss of my self in the heart of the cosmos, and the white, however intelligent he may be, will never be able to understand [Louis] Armstrong or the songs of the Congo] (Fanon, 1952: 36 [1986: 45]).

As we saw in the introduction to this chapter, David Macey has written rather dismissively of Fanon's allusion to jazz here, claiming it proves the latter 'was less interested in the music itself than in the sociological phenomenon of black music in the racist white society of the United States' (Macey, 2000: 124). This is surely both to underestimate and to misunderstand what Fanon is driving at here. For although his remarks are clearly parodic, they present a by no means wholly unfair caricature of the interpretation of jazz Senghor had offered in his essay 'Ce que l'homme noir apporte'. As we have seen, Panassié's jazz criticism does indeed present jazz appreciation as some kind of mystical communion with an ineffable spiritual force. In articulating Panassié's work to négritude, Senghor had, in turn, endowed jazz with an almost mystical spiritual force, seeing it as the expression of the nègre's organic communion with the earth and the natural rhythms of nature. Fanon's point is that this conception of négritude, in general, and of jazz, in particular, rehearses and reinforces the primitivist stereotypes on which colonial discourse depends. In his subsequent remarks on jazz in both the 1956 essay 'Racisme et culture' and Les Damnés de la terre (1961), he would suggest that modern jazz might, at the aesthetic level, be capable of figuring a way out of this trap, of uncoupling jazz from any organic link its promoters might claim it possessed to either specified geographical location or fixed ethnic identity. On the basis of that uncoupling, modern jazz might indeed become pertinent to discussions of a national culture in a newly independent Algeria.

\section{From the Guerre du Jazz to the Guerre d'Algérie}

In Les Damnés de la terre, Fanon returns to the question of négritude's interpretation of jazz, in a section in which he discusses the nature of the new 'national culture' that should be forged in any nation struggling to free itself from Western imperial rule. His primary concern is that such a national culture should not reflect the fetishization of national tradition; it should not be purely backward-looking, nativist or primitivist but should, rather, reflect decolonized peoples' active engagement in the historical dialectic. To exemplify his point, Fanon turns once more to jazz and, more specifically, to what he terms the 'réactions des spécialistes blancs du jazz quand, après 
la deuxième guerre mondiale se cristallisèrent de façon stable de nouveaux styles comme le be-bop' [the reactions of white jazz specialists, when, after the Second World War, new styles such as bebop took definitive shape] (Fanon, 1961: 291 [1986: 195]). This is an allusion to the so-called guerre $d u$ $j a z z$, that fierce dispute between, on one side, those who claimed traditional or New Orleans jazz was the only true jazz and hence that modern jazz or bebop was an aberration and those, on the other, who defended the new music. As we have seen, Panassié was the best-known, most vocal and most influential member of the traditionalist school of thought. For Fanon, the cultural and political implications of this dispute are clear. Those who adopt Panassié's position betray their investment in a fixed, nostalgic and primitivist conception of black identity, whilst those who champion bebop acknowledge black peoples to be active agents on the historical stage. As he puts it,

C'est que le jazz ne doit être que la nostalgie cassée et désespérée d'un vieux nègre pris entre cinq whiskies, sa propre malédiction et la haine raciste des Blancs. Dès lors que le nègre s'appréhende et appréhende le monde différemment, fait naître l'espoir et impose un recul à l'univers raciste, il est clair que sa trompette tend à se déboucher et sa voix à se désenrouer. Les nouveaux styles en matière de jazz ne sont pas seulement nés de la concurrence économique. Il faut y voir à n'en pas douter une des conséquences inéluctables de la défaite, inéluctable quoique lente, de l'univers Sudiste aux États-Unis. Et il n'est pas utopique de supposer que dans une cinquantaine d'années la catégorie jazz-cri hoqueté d'un pauvre nègre maudit sera défendue par les seuls Blancs, fidèles à l'image stoppée d'un type de rapports, d'une forme de la négritude. ${ }^{6}$ (Fanon 1961: 291)

Although again quite brief, Fanon's remarks here work on a number of interrelated levels. On one level, they demonstrate a keen awareness of the

6 'Jazz must not merely be the broken and despairing nostalgia of an old Nègre, caught between five whiskies, his own accursed state, and the racist hatred of the Whites. Once the Nègre apprehends himself and the world differently, fosters some hope and imposes some distance on the racist universe, it is clear that he tends to give up playing with a muted trumpet and his voice tends to become less husky. The new styles in jazz are not only the products of commercial competition. We must, without doubt, see them as one of the consequences of the defeat, ineluctable if slow, of the system of the American South. And it is not utopian to suppose that in fifty years or so the category of jazz as the stammered cry of a poor accursed Nègre will only be defended by Whites who remain faithful to the arrested image of a kind of relations, of a form of négritude' (Fanon, 1986: 195-95; translation modified). 
possible political implications of the guerre $d u$ jazz, of the extent to which the positions adopted by a Panassié in favour of New Orleans jazz reflected his investment in a primitivist and essentialist conception of black identity. Fanon also shows his understanding here of the close relationship between Panassié's jazz criticism and Senghor's négritude. As we have seen, in 'Ce que l'homme noir apporte' Senghor had claimed that all African Americans were nostalgic for the plantations of the South, that such nostalgia reflected their essentially organic relationship to the land, an organic relationship expressed in the rhythms of jazz, as in other inherently nègre cultural forms. It is these organic relationships between identity, geography and cultural expression that Fanon rejects here. He also shows his interest in the sociological conditions which enabled modern jazz or bebop to develop. Bebop was a fundamentally urban phenomenon; it first emerged in jam sessions in various New York jazz clubs and was thus one product of African Americans' literal movement away from the plantations of the South, in search of a better life in the cities and factories of the North. Figuratively, bebop also represented a conspicuous attempt by African-American musicians to distance themselves from the world of the Southern plantations. The sharp suits and ostentatiously 'cool' demeanour of the beboppers stood in stark contrast to the clowning and 'mugging' that characterized the performances of a Louis Armstrong and reflected the formers' overt refusal to play the role of the black clown or minstrel. The harmonic sophistication, dissonances, dizzyingly fast chord changes and rhythmic complexities that characterized bebop performances similarly represented a refusal of the role of simple, instinctive black musicians in favour of a claim to virtuosity and hence human dignity. As Fanon explains here, the political and sociological aspects of the emergence of modern jazz were thus reflected and expressed in the new music's properly aesthetic or musical characteristics, in what he describes as the rejection of the traditional blues tonality of muted trumpets or mournful, nostalgic singing voices.

Quite what Fanon has in mind in this last instance can be clarified by examining the precise role of blues idioms in bebop or modern jazz, whether in the form of a characteristic blues tonality or the traditional twelve-bar blues structure that had been the foundation stone of so much earlier jazz. These blues forms are generally considered to have their origins in the collision in the New World between West African melodies and field hollers, on the one hand, and Christian hymn harmonies, work songs and their associated call and response patterns on the Southern plantations, on the other. For the musicians who pioneered bebop, then, blues forms were associated with the American South and with enduring stereotypes as to African Americans' fundamental simplicity and lack of social or intellectual 
sophistication. As Dizzy Gillespie put it, 'The be-bop musicians didn't like to play the blues. They were ashamed. The media had made it shameful' (quoted in DeVeaux, 1997: 343). However, this did not mean that the beboppers simply abandoned the blues, not least because they knew that the African-American jazz audience had come to expect and felt comfortable with blues forms. Hence, rather than simply rejecting what they took to be the demeaning, earthy, crude forms of the blues, they integrated those forms into their music, transforming the blues idiom as they did so by means of the virtuosity of their harmonic, tonal, and rhythmic innovations. In this way, the beboppers sought to transcend the restrictive racial stereotypes they feared the blues otherwise risked reproducing. As Scott DeVeaux explains in his study of bebop, 'The beboppers' frustration with the technical limitations of the older blues style was easily overcome. By fusing traditional blues gestures with a speeded-up double time and couching their language in chromatic dissonance, they imposed a new feeling of swing on the old' (DeVeaux, 1997: 343). DeVeaux continues,

As upwardly mobile professionals, they [the beboppers] distanced themselves from the rural blues milieu even as they trafficked in its gestures and techniques. Their distancing, however, was no retreat. The progressive urge - in social and cultural terms as well as musical demanded that musicians take responsibility for elevating the taste of the people they entertained. Their very existence as a professional elite gave the lie to the stereotype of the unlettered Negro singing lewd blues to his guitar. Every sharp, impeccably pressed outfit, every intricate phrase executed with faultless intonation and technique, was a challenge to white assumptions of cultural supremacy and to black resignation to social inferiority. (DeVeaux, 1997: 345)

The relationship DeVeaux describes here between the musical innovations of the beboppers and the more traditional blues idiom is essentially a dialectical one in which a musical tradition is integrated and preserved in a new musical form even as its inherent flaws and limitations are transcended. In this sense, be-bop's transformative integration of older blues forms mirrors almost precisely the relationship between cultural tradition and political engagement Fanon sketches out in his 1956 essay 'Racisme et culture', an essay in which jazz is once again accorded a pivotal role. Here Fanon points out that colonialism does not operate by simply extinguishing all trace of the traditional culture of indigenous colonized peoples. Rather, it tends to exoticize, romanticize and hence freeze traditional indigenous cultures in aspic. Hence, such cultures, paradoxically, serve to reproduce rather than undermine colonial racism. In searching for an example of this process, 
Fanon turns once more to blues and to the traditional, New Orleans jazz played by Louis Armstrong. As he puts it,

C'est ainsi que le blues 'plainte des esclaves noirs' est présenté à l'admiration des oppresseurs. C'est un peu d'oppression stylisée qui revient à l'exploitant et au raciste. Sans oppression et sans racisme, pas de blues. La fin du racisme sonnerait le glas de la grande musique noire ... Comme dirait le trop célèbre Toynbee, le blues est une réponse de l'esclave au défi de l'oppression. Actuellement, pour beaucoup d'hommes même de couleur, la musique d'Armstrong n'a de véritable sens que dans cette perspective. Le racisme boursouffle et défigure le visage de la culture qui le pratique. La littérature, les arts plastiques, les chansons pour midinettes, les proverbes, les habitudes, les patterns, soit qu'ils se proposent d'en faire le procès ou de le banaliser, restituent le racisme.7 (Fanon, 1956: 38-39)

In these circumstances, where the protests against slavery and oppression contained in the blues or Louis Armstrong's jazz paradoxically contribute to the reproduction of racist stereotypes, the tendency for oppressed peoples to turn to their own cultural traditions as a source of solace, dignity and identity will always be highly ambivalent. The turn to native cultural tradition will always risk simply revalorizing a culture that is 'encapsulée, végétative' [bottled, vegetative], a culture that has not been 'repensée, reprise, dynamisée de l'intérieur' [rethought, grasped anew, dynamized from within] (Fanon, 1956: 43 [1970: 52]). Nonetheless, whilst this 'redécouverte [et] revalorisation absolue' [rediscovery [and] complete revalorization] of traditional culture is 'objectivement indéfendable' [objectively indefensible], it retains 'une importance subjective incomparable' [an incomparable subjective importance]. As Fanon puts it, 'la plongée dans le gouffre du passé est condition et source

7 'Thus the blues, as "the lament of the black slave", is offered up for the admiration of the oppressors. This modicum of stylised oppression is the exploiter's and the racist's rightful due. Without oppression and without racism, there is no blues. The end of racism would sound the death knell of great black music. As the all too famous Toynbee would say, the blues are the slave's response to the challenge of oppression. Still today, for many people, even those of colour, Armstrong's music only makes sense in this context. Racism bloats and disfigures the face of the culture which practises it. Literature, the plastic arts, sentimental popular songs, proverbs, habits, cultural patterns, whether they intend to criticise it or make it commonplace, end up reinforcing racism' (Fanon, 1970: 47; translation modified). The 'Toynbee' mentioned here is presumably the British historian Arnold J. Toynbee, whose multi-volume A Study of History (1934-61) is a Spenglerian study of the rise and fall of different world cultures and civilizations. 
de liberté' [plunging into the chasm of the past is the condition for and source of freedom] (Fanon, 1956: 44 [1970: 53]). Plunging into the roots of one's cultural identity and traditions thus becomes the necessary first step in a dialectical process that will aim to redynamize those traditions, to transcend and hence escape their primitivist or essentialist limitations. The catalyst for that dynamic, dialectical process will be, according to Fanon, the anti-colonial struggle itself (Fanon, 1956: 45 [1970: 53]). ${ }^{8}$

If in 'Racisme et culture' the catalyst for this dialectical sublation of a fetishized cultural tradition is the anti-colonial struggle, in his remarks on modern jazz in Les Damnés de la terre that catalyst is identified as the movement North of African Americans in search of a better life, their literal and figurative rejection of the plantation society of the American South. Bebop or modern jazz is important for Fanon not because it is taken to be an organic expression of a specified ethnic identity rooted in West Africa and transplanted to the American South, as Senghor's reading of jazz and négritude would have it. Rather, modern jazz's importance reflects its ability to express a historical process of change undergone by one specific ethnic group, namely African Americans, in their struggle against continuing oppression and racial discrimination. Here I am employing Peter Hallward's useful distinction between the 'specified' and the 'specific'. For Hallward, a 'specified identity' corresponds to a fixed and unchangeable essence, an identity 'defined by positive, intrinsic characteristics as essences (physical, cultural, personal, and so on)'. A 'specific understanding of individuals and situations', on the other hand, grasps such individuals and situations as being 'conditioned', but not absolutely determined, 'by the relations that both enable and constrain their existence' (Hallward, 2003: 274-75). It is because Fanon interprets modern jazz as reflecting the specific situation of racial oppression faced by African Americans, rather than their specified ethnic identity, that this musical form can be wholly pertinent both to Fanon, as a French Antillean, and to Algerians fighting for their independence, inasmuch as all suffer analogous forms of racial oppression, relating to their specific status as colonial subjects and/or ex-slaves. The pertinence of modern

8 The dialectic Fanon theorizes here is clearly indebted to the dialectical vision elaborated by Jean-Paul Sartre in his famous essay 'Orphée noir' (Sartre, 1948). This represents a shift from Fanon's position in Peau noire, masques blancs, where he had argued that Sartre's characterization of négritude as the 'moment faible' [weak moment] in the dialectical movement of black liberation was an 'erreur' [a mistake] since it risked dissolving the realities of black experience and culture in an all-encompassing dialectical process (Fanon, 1952: 107-09 [132-35]). 
jazz to both Algeria and to Fanon's own situation does not rest upon its ability to express some spurious, specified ethnic identity, shared by French Antilleans, African Americans and Algerians alike. Rather, its pertinence rests upon its ability to give aesthetic figuration to that dialectical process whereby a specific situation is transcended, namely that situation in which the victims of racial oppression find their cultural traditions simultaneously denigrated and exoticized by those who oppress them. Understood as the aesthetic figuration of a specific dialectical process, rather than as the organic expression of a specified ethnic identity, modern jazz can thus be entirely pertinent to a discussion of the form any national culture might take in a newly independent Algeria. In this sense, and contrary to what David Macey seems to assume, the pertinence of modern jazz to the Algerian situation does not even rely on any inherent affinity between bebop and the musical tastes or aesthetic sensibilities of Algerians, on the Algerians liking or knowing much about modern jazz. Similarly, Fanon's engagement in the Algerian struggle cannot, pace Vergès, be read as relying on an illegitimate claim to Algerian 'filiation' and hence a 'disavowal' of his true Creole identity. Indeed, modern jazz provides Fanon with a model, at the aesthetic level, of how that identity might be integrated into a transformative project, in such a way that its components are re-dynamized and its inherent limitations transcended. By analogy, at the political level, Fanon's solidarity with the Algerian cause rests on an awareness of a shared specific situation, rather than any illegitimate claim to a common specified identity.

As we have seen, whether in his explorations of his own identity as a French Antillean subject, in his writings on the Algerian situation or on anti-colonial and anti-racist struggle more generally, Fanon makes repeated allusions to jazz music. Although these allusions are typically quite brief, they occur at pivotal moments in his argument and, on closer examination, reveal a detailed understanding of the music, of its critical reception and of the potential political implications of both. It is important to play close attention to these allusions if we wish to understand precisely how Fanon conceptualizes the specific relationships between his own French Antillean identity, the struggles of African Americans to escape the oppressive conditions of the American South and the struggles of the Algerian people for their independence.

\section{Works Cited}

Bernasconi, Robert. 2002. 'The Assumption of Négritude: Aimé Césaire, Frantz Fanon, and the Vicious Circle of Racial Politics'. Parallax 8.2: 69-83. 
DeVeaux, Scott. 1997. The Birth of Bebop: A Social and Musical History. Basingstoke: Picador.

Edwards, Brent Hayes. 2003. 'Translating the Word Négre'. In The Practice of Diaspora: Literature, Translation, and the Rise of Black Internationalism. Cambridge, MA and London: Harvard University Press: 25-38.

Fanon, Frantz. 1952. Peau noire, masques blancs. Paris: Éditions du Seuil [English translation by Charles Lam Markmann: Black Skin, White Masks. London and Sydney: Pluto Press, 1986].

-. 1956. 'Racisme et culture'. Reprinted in his Pour la révolution africaine. Paris: Maspéro, 1961: 33-45 [English translation by Haakon Chevalier: 'Racism and Culture'. In Frantz Fanon, Toward the African Revolution. Harmondsworth: Penguin, 1970: 39-54].

- 1961. Les Damnés de la terre. Preface by Jean-Paul Sartre, Introduction by Gérard Chaliand. Paris: Éditions Gallimard/Folio actuel, 1991 [English translation by Constance Farrington: The Wretched of the Earth. London: Penguin, 2001].

Gennari, John. 2006. Blowin' Hot and Cool: Jazz and its Critics. Chicago, IL and London: Chicago University Press.

Hallward, Peter. 2003. Badiou: A Subject to Truth. Foreword by Slavoj Žižek. Minneapolis: University of Minnesota Press.

Hodeir, André. 1954. Hommes et problèmes du jazz. Paris: Le Portulan.

Macey, David. 2000. Frantz Fanon: A Life. London: Granta Books.

Maritain, Jacques. 1920. Art et scolastique. Paris: Louis Rouart et fils.

—. 1936. Humanisme intégral: problèmes temporels et spirituels d'une nouvelle chrétienté. Paris: Éditions Ferdnand Aubier.

Panassié, Hugues. 1934. Le Jazz hot. Introduction by Louis Armstrong, foreword by Eugène Marsan, illustrations by Roger Chastel. Paris: Éditions R.-A. Corrêa.

—. 1937a. 'Le Malentendu du jazz hot', L'Insurgé 27 January 1937: 5.

—. 1937b. 'La Revue du Cotton Club', L'Insurgé, 16 June 1937: 5.

-. 1959. Histoire du vrai jazz, Paris: Robert Laffont.

—. 1965. La Bataille du jazz, Paris: Albin Michel.

Sartre, Jean-Paul. 1948. 'Orphée noir'. Preface to L. S. Senghor, Anthologie de la nouvelle poésie nègre et malgache de langue française. Paris: Presses universitaires de France: ix-xliv.

Senghor, Léopold Sédar. 1939. 'Ce que l'homme noir apporte'. Reprinted in his Liberté, Vol. 1, Négritude et humanisme. Paris: Éditions du seuil, 1964: 22-38.

Shennan, Andrew. 1989. Rethinking France: Plans for Renewal, 1940-1946. Oxford: Clarendon Press.

Tournès, Ludovic. 1999. New Orleans sur Seine: histoire du jazz en France. Paris: Fayard. 
Vergès, Françoise. 1997. 'Creole Skin, Black Mask: Fanon and Disavowal'. Critical Inquiry 23: 578-95.

-. 2005. 'Where to Begin? "Le Commencement" in Peau noire, masques blancs and in creolisation'. In Max Silverman (ed.), Frantz Fanon's Black Skin, White Masks: New Interdisciplinary Essays. Manchester and New York: Manchester University Press: 32-45.

Wilder, Gary. 2005. The French Imperial Nation-State: Negritude and Colonial Humanism between the Two World Wars. Chicago, IL and London: Chicago University Press. 


\title{
The Sorcerer and the Quimboiseur: Poetic Intention in the Works of Miles Davis and Édouard Glissant
}

\author{
Jean-Luc Tamby
}

Édouard Glissant's writing is deeply rooted in a strategy that challenges a hegemonic form of language use, ${ }^{1}$ as described in detail by Celia Britton, with particular reference to his essays and novels (Britton, 1999). Miles Davis's music, too, can be interpreted as a counter-discourse. The literature of the Caribbean and jazz music in the United States belong in fact to areas of cultural activity which have comparable histories despite their dissimilarities. A comparative approach to Glissant's writing and the trumpet player's improvisations can therefore allow us to reflect on the connections between strategies of resistance and, on the other hand, the emergence in these two artists of independent formal concerns.

We do find references to music from time to time in Glissant's writings on poetics. He quotes Bob Marley in Poétique de la relation (Glissant, 1990: 107) and frequently mentions jazz in particular as an example of 'pensée de la trace' [trace thought]. It has to be said, though, that the position of music in his poetics is not as prominent as that of literature and the visual arts. Nevertheless, the limited number of references to music in Glissant's writings is perhaps not an accurate reflection of the true importance of this art to his poetics. The author of Sel noir in fact asserts: 'Il y a une mesure secrète des formes de la musique et de la philosophie, les deux arts les plus proches à la fois dans leur précision et leur évanescence' [There is a secret time signature in the structures of music and philosophy, the two arts which are closest to

1 Glissant's fictional quimboiseur, Papa Longoué, in Le Quatrième Siècle, is a healer, a seer and a storyteller. 
each other in both their precision and their evanescence] (Glissant, 2006: 116). ${ }^{2}$ One of the most intense prose pieces in La Cohée du Lamentin, entitled 'Au plus obscur des musiques' [Music at its most obscure] (Glissant, 2005: 243), is on the subject of silence and music as they enter into contact with the vastness of the world. And, during a press conference given on 21 July 2007 in the Basque village of Itxassou to introduce his collaboration with the multiinstrumentalist Bernard Lubat, the poet declared: 'Mon style d'écriture est le style de jazz de Miles Davis' [My writing style is the jazz style of Miles Davis].

In common usage, when the term 'style' is associated with a writer it tends to define individual character. 'Le style est l'homme même' [style is the man himself] declares Buffon in his Discours sur le style. 'On peut empiriquement constater que chaque écrivain a son style propre' [we can ascertain empirically that each writer has his own style], adds Etienne Souriau (Souriau, 1990: 1315). Roland Barthes refers to 'des images, un débit, un lexique' that 'naissent du corps et du passé d'un écrivain et qui deviennent peu à peu les automatismes même de son art' ['imagery, delivery, vocabulary' that 'spring from the body and the past of the writer and gradually become the very reflexes of his art'] (Barthes, 1953: 12 [Barthes, 1977: 10]). Édouard Glissant's style is not that of Léon Gontran Damas. Style is an important part of the identity of these writers, distinguishing them from each other, serving as their 'langage autarcique' [autarchic language]. When applied to music, the concept of style often extends beyond the individual. For historians of music, the works of Mozart and Haydn are both written in the Classical style which provided the title of Charles Rosen's famous book. At the beginning of the 1950s, Miles Davis's and Dizzy Gillespie's choruses grew out of the same bebop style, despite their many formal differences. ${ }^{3}$ (We can nevertheless still speak of a musical work 'in the style of' Bach or Mozart, which implies an individual referent for the word 'style').

Taken literally, Glissant's remark suggests that his own writing style and the jazz style of Miles Davis are identical. In this, he extends the concept of style to embrace two distinct artists and arts. This type of shift, operating through displacement and a broadening of focus, often dictates the hermeneutic movement that Glissant's poetics invites us to follow.

2 Where a published translation of a work in French exists, with the exception of Glissant's poetry, this is cited, with references. Where no published translation is available and no references are provided, the translation is the work of the translator of this chapter. A simple literal translation has been provided of the poetry.

3 In jazz, the term 'chorus' is used to describe one full cycle of a song's form. Choruses can be performed by either a solo instrument or an ensemble. 
Accordingly, the concept of 'Creolization' involves the deterritorialization of a properly Caribbean linguistic and cultural reality as perceived by the poet. The opposition between langue [language] and langage [language use] postulated by Édouard Glissant can equally allow us a better understanding of the poet's thoughts on style. He observes that a discourse community is to be found in the Caribbean that goes beyond the linguistic differences between English, French, Creole languages and Spanish. Langage in Glissantian poetics is, therefore, according to Celia Britton, 'un pont entre les langues' [a bridge between languages] (Britton, 2008: 238). Langage is even 'un voyage' [a journey] (Glissant, 1993: 307) for the writer. Style, too, according to Glissant, can also be conceived as a bridge, not between languages, but between arts.

The poet observes that a 'communauté de structures discursives' [community of discursive structures], to borrow Celia Britton's formulation, extends beyond langage and the Caribbean, to embrace the totality of cultures which have suffered the consequences of the slave trade. This is what Glissant calls 'pensée de la trace' [trace thought], under which heading he explicitly includes music.

Dans les pays composites, et par exemple pour les cultures créoles des Amériques, l'avancée s'est faite par traces. L'essentiel de la population y est arrivée nue, c'est-à-dire après avoir été dépouillée des artefacts de sa culture originelle, de ses langues, de ses dieux, de ses objets usuels, ses coutumes ses outils et il lui a fallu recomposer, par traces, 'dans les savanes désolées de la mémoire', ce qui lui restait des anciennes cultures ataviques [...]. Le jazz du sud des États Unis comme les musiques de la Caraïbe et du Brésil ont d'abord constitué une remontée de la trace africaine [...] et les langues créoles de la Caraïbe ont aussi procédé par traces pour constituer leur corpus lexical et syntaxique. ${ }^{4}$ (Glissant, 2006: 188).

Langage and the trace bring together different cultural phenomena within a single community. They also bring together communities who are widely

4 'In culturally composite countries and, for example, in the case of the Creole cultures of the Americas, advances are accomplished by means of traces. Most of the population have arrived there naked, that is to say deprived of the artifacts of their original cultures, of their languages, of their gods, of their daily objects, their customs, their tools, and they have had to reconstruct, through traces, "in the desolate savannahs of memory", the remains of their earlier atavistic cultures [...]. The jazz of the southern United States, like the musical cultures of the Caribbean and Brazil, initially followed the African trace [...] and the Creole languages of the Caribbean also built up their lexical and syntactic corpuses by means of traces.' 
separated by either geography or linguistic differences but have been brought closer to each other by the history of the slave trade. Glissant thus sees the discursive structures of the Caribbean tale in other forms of art and in other locations. He evokes an aesthetic which is born of silence and of deferred speech deep within the plantation:

La nuit des cases a enfanté cet autre énorme silence d'où la musique incontournable, d'abord chuchotée, enfin éclate en ce long cri. Cette musique est spiritualité retenue, où le corps s'exprime soudain. [...] ces musiques nées du silence, negro spirituals et blues, continuées dans les bourgs et les villes grandissantes, jazz, biguines et calypsos, éclatées dans les barios et favelas, salsas et reggaes, rassemblent en une parole diversifiée cela qui était crûment direct, douloureusement ravalé, patiemment différé. ${ }^{5}$ (Glissant, 1990: 88)

These global discursive structures: the trace and langage, seem to me to come close to what Glissant is describing when he talks about style. They also closely resemble Alain Locke's concept of idiom. The American anthropologist suggested that a shared idiom, born out of the traces of African cultures, links not only the different musical traditions of the Americas but also their styles of dress and habits of daily life, even extending the connection to the European artistic movement of cubism (Locke, 2009: 29). Anthony Mangeon describes the Lockean idiom as the 'produit d'attitudes émotionnelles privilégiées, de préférences dispositionnelles constituées dans l'expérience, lesquelles sont à leur tour constitutives d'un rapport au monde, d'une personnalité, d'un tempérament, tempérament dont l'art et plus particulièrement la poésie et la musique nègres sont les vecteurs privilégiés' (Mangeon, 2004: 466). ${ }^{6}$ The concepts of trace, langage and style, as referred to by Glissant, appear to correspond to Locke's idiom. Idiom, however, places

5 'Night in the cabins gave birth to this other enormous silence from which music, inescapable, a murmur at first, finally burst out into this long shout - a music of reserved spirituality through which the body suddenly expresses itself. [...] These musical expressions, born of silence: Negro spirituals and blues, persisting in towns and growing cities; jazz, biguines, and calypso, bursting into barrios and shantytowns; salsas and reggaes, assembled everything blunt and direct, painfully stifled, and patiently differed into this varied speech' (Glissant, 1997: 73).

6 'product of particular emotional attitudes, of dispositional preferences constructed through experience, which in their turn constitute the building blocks of a relationship with the world, of a personality, of a temperament, a temperament for which art and, more particularly, negro poetry and music are the preferred vehicles.' 
particular emphasis on an aesthetic viewpoint, including reception, whereas the concepts developed by Glissant are situated rather on the poïtic side of creative endeavour.

Glissant's formulation, understood literally, would thus define an aesthetic community bringing together several artistic disciplines that could be thought of as a synthesis of the concepts of langage and trace, closely resembling the concept of idiom developed by Alan Locke. Style in this case primarily has a collective value.

In his own definition of the concept of style, Nelson Goodman provisionally proposes that it should be described as a signature (Goodman, 1992: 59). I would revise this to 'formal signature'. Under this definition, Glissant's words can only be understood as a metaphor: the identity of a writer cannot be that of a musician nor, moreover, that of another writer, except in cases of pastiche or plagiarism. As formulated, the metaphor establishes an analogy between two creative outputs, one musical, the other literary. Since style, according to Roland Barthes, is already a metaphor that establishes equivalence between 'l'intention littéraire et la structure charnelle de l'auteur' (Barthes, 1953: 13) [the author's literary intention and carnal structure (Barthes, 1977: 12)], the new metaphor formulated by Glissant becomes part of a metaphorical chain characterizing artistic expression and the relationship between its different forms.

As Jean-Louis Backès remarks, the analogy between music and literature is not a scientific one (Backès, 1994: chap. 4). Like all metaphorical processes, it requires our good will and a subjective response. Rhythm in music is not the same as the rhythm of poetry. When musical or melodic terms are applied to poetry they are only metaphors whose validity cannot be proven. Any formal analogy between music and poetry must therefore be the result of interpretation. The latter is rendered even more complex by the unity implied in the terms 'style d'écriture' [writing style] and 'style de jazz' [jazz style] when considering corpuses as abundant and protean as Glissant's writings and Davis's music.

Glissant's works can be divided into three equally important groups: the novels, the essays and his poetry. Within each genre we encounter great variety in the forms of writing. Thus, the essays include image-laden poetic prose, aphorisms and conceptual developments. The poetry includes narrative epic poems, such as Le Sel noir and Les Indes, prose poems that verge on the lyrical, fragments where syntax is broken down and compositions that are more rhythmic in nature. The novels are also varied in style and structure, including prose works with such intensive imagery that they are almost poems, discursive prose pieces which resemble essays, narratives and interior monologues. The poet accepts the divisions provided 
by the traditional generic categories but constantly overturns them, disturbs them or 'creolizes' them. Glissant's writing itself cannot be summed up in terms of a tone or a cadence. For example, we find extreme variations in the sentence lengths of the essays. In 'Lespace d'une journée' (Glissant, 2006: 11-17) the sentences get progressively longer until the full stop disappears. The Caribbean writer's work here resembles a flood not unlike the prose of James Joyce's novels:

Alors ici vous consultez toutes ces roches de rivières polies et lustrées qui sont accourues rencontrer les gros morceaux déchiquetés de rocs et de laves froidies, et autour du Rocher, lui-même en paquets mais tout en un et ses creusements comme des yeux de nuit ou des bouches d'ombre et ses saillies comme des nez démantelés taris, et du rivage jusqu'ici, vous considérez comment la parole d'abord confuse s'est mêlée de sable gris, les mots sont raides et décarrés dans la page, et s'est éclairée d'un charroi de grosses ténèbres propices et s'est éclaircie d'un infini de ces sens qui tous tremblent là [...].7 (Glissant, 2006: 18)

By contrast, La Cohée du Lamentin and Traité du tout-monde employ a technique of fragmentation. In the excipits of the former, such fragments are in the form of maxims, each sentence constituting an independent entity:

LE TOUT-MONDE, L'OBJET LE PLUS HAUT DE POETIQUE, EST, AUSSI, L'IMPREVISIBLE. EN QUOI IL EST CHAOS MONDE. J'ECRIS EN PRESENCE DE TOUTES LES LANGUES DU MONDE. (Glissant, 2005: 37)

The expression 'vertige des styles' [dizziness of styles] used by Édouard Glissant to describe baroque aesthetics (Glissant, 1990: 92) could thus apply to his own work. It could also define the musical career of Miles Davis. The trumpet player worked through almost all the jazz styles of the second half of the twentieth century. Having started out at Charlie Parker's side, in the

7 'Here then you consult all these polished and sparkling river stones which have raced to join the great jagged lumps of rock and cold lava, and around the Rock, itself in clusters but forming a single mass and its gouges like night eyes or shadow mouths and its projections like broken up dried up headlands, and from the shore to here, you consider how speech that was originally confused has been mixed with grey sand, the words are unyielding and have escaped into the page, and has been lit up by a convoy of vast auspicious shadows and has been brightened by an infinity of those senses which are all trembling there [...].'

8 'The tout-monde, the highest object of poetics, is, also, the unpredictable. In which it is chaos-monde. I write in the presence of all the languages of the world.' 
midst of the excitement of bebop, he was an instigator in the development of modal jazz, followed by what was later called post bop, or 'controlled freedom'. He was the creator of jazz rock and ended his career close to pop music. With each aesthetic change, he shifted the parameters of complexity and the balance between them: simplifying harmonic structure in order to free up the melodic language of the album Kind of Blue (Davis, 1959); integrating polyrhythms and polytonality with his second quintet; then simplifying the polyrhythms while increasing the complexity of the contrapuntal texture and tonality in the album Bitches Brew (Davis, 1970). In this process, Davis integrated and reworked a mass of influences, from Stravinsky to James Brown, via Prince and Stockhausen.

Davis also turned his attention to the concept of style, but he gave this term a meaning which was both broad and, to say the least, enigmatic: 'But you've got to have style in whatever you do: writing, music, fashion, boxing, anything. Some styles are slick and creative and imaginative and innovative and others aren't. For me, music and life are all about style' (Davis and Troupe, 1989: 181).

Nevertheless, beyond this interweaving of forms and languages, there is a unity in each of Glissant's works, as in Davis's music, to which few other creators can aspire. Between these two diverse unities, the poet calls on us to distinguish a shared poetic intention.

When I asked him how his writing style and the jazz style of the trumpet player could be linked, Glissant promptly answered: 'par le rythme' [through rhythm]. Rhythm, for which there is no easy definition, is at once, according to Pierre Sauvanet, cosmic, biological and aesthetic in character (Sauvanet, 2000: chap. 1). I shall provisionally draw on André Lalande's very general definition of rhythm as the 'caractère périodique d'un mouvement ou d'un processus' [periodic character of a movement or process]. The philosopher further suggests that we should understand rhythm primarily as 'le caractère d'un mouvement périodique en tant qu'il compose une succession de maxima et de minima' [the character of a periodic movement considered as a series of maximum and minimum values] (Lalande, 1926: 935).

Aesthetic rhythms exist in complex symbolic relationships with biological and cosmic rhythms. Édouard Glissant writes that he uses breathing to measure the pace of his poetry:

En poésie le verset de Claudel ou de Saint John Perse ou celui des livres de la bible correspond à la mesure du souffle humain mieux que l'alexandrin. Le verset est ce que l'on peut dire le temps d'un souffle. J'ai essayé inconsciemment de faire la même chose dans l'écriture, et je ne m'en suis rendu compte qu'après. C'est à dire amener la phrase au bord 
de la rupture et de l'explosion pour que le lecteur lui-même se sente à ce point de rupture! C'est une technique de l'oralité que je fais entrer dans l'écriture. ${ }^{9}$ (Glissant, 2001: 37)

Miles Davis, too, constructs his improvisations around breathing. His phrases develop according to the rhythm of the silences and gaps which unrelentingly punctuate them. In this sense, his style is the opposite, for example, of Sonny Rollins or of Dizzy Gillespie, both users of circular breathing techniques to free themselves from breathing constraints. In Davis, this habit of listening to his own limits gradually becomes more marked as his style develops, but also as his strength declines. We can hear this method of building the music around a cycle of breaths in the famous chorus of 'All Blues' on the album Kind of Blue. The moments of silence and breathing around which the musician constructs his improvisation recur periodically but unpredictably. This irregular pattern contrasts with the regularity of the chord progressions and of the ostinato of the drums and bass. The moments of silence appear to coincide with moments of reflection on the part of both the musician, who considers what he will play next, and the listener, who can take the time to make sense of the pattern that he has just perceived. At other times the trumpet player's breathing becomes a space which allows the pianist to establish a dialogue and to step, for a brief moment, out of his accompanist's role.

In Glissant's poetry the rhythm constructed around breathing is explicit, for example in these verses taken from La Terre inquiète:

Sable, saveur de solitude! quand on y passe pour toujours.

O nuit! plus que le chemin frappé de crépuscules, seule.

À l'infini du sable sa déroute, au val de la nuit sa déroute, et sur le sel encore,

Ne sont plus que calices, cernant l'étrave de ces mers, où la délice m'est infinie.

Et que dire de l'Océan, sinon qu'il attend? ${ }^{10}$

(Glissant, 1994: 103)

9 'In poetry, the lines of Claudel, Saint John Perse or the books of the Bible are closer to the pattern of human breathing than is the alexandrine. The line is that which can be spoken in the space of a breath. I have subconsciously tried to achieve the same thing in my writing, a fact which I have only subsequently realized. That is to say that I take the sentence to its breaking point, the point of explosion, so that the reader also feels himself to be at that breaking point! It is an oral technique that I incorporate in my writing.'

10 'Sand, taste of solitude! when you enter it for eternity / Oh night! nothing 
Glissant uses punctuation in the form of exclamation marks and commas as echoes of orality. At the ends of the segments interrupted by these marks, the recurrence of the mute $e$ (in the words solitude, crépuscules, seule, déroute and encore) generates a bell-like effect which increases the musicality of these verses and gives them a quality of cantillation. Organization based on breathing patterns can be heard not only in the poetry but also in the prose of Édouard Glissant; we can accordingly hear it in this extract from Philosophie de la relation:

J'ai touché cet arbre du voyageur, que j'avais transplanté en l'autre saison du carême. Sa ramure balayée par le cyclone Dean. Je lui parle doucement. Dans l'éclair d'une semaine, il a poussé de nouvelles feuilles vert pâle. Je ne lui commande pas, il m'emprunte et me donne. C'est en face du rocher du Diamant. ${ }^{11}$ (Glissant, 2009: 71)

The breathing patterns incorporated in the writing bring it closer to the spoken word. Combined with the power of metaphor, they give the proffered words the impression of an almost prophetic strength, powerful enough to reach beyond language and physical experience. At the same time, the constraints of breathing draw the poetic discourse back to its physical origins and assert their immanence.

Taking this dialogue between emptiness and plenitude as his starting point, Miles Davis creates complex melodic phrases whose development is nevertheless clearly structured between protasis and apodosis or clearly oriented towards masculine or feminine closing cadences. This almost calligraphic art of musical phrasing brings Davis's improvisations close to a form of writing. The structure in the first chorus of So What (Davis, 1959) can accordingly be heard to privilege symmetry over surprise. The trumpet player begins his chorus by developing a motif based on the interval of a fifth and bringing out the ninth of the chord. The ascending transposition of the modal scale brings about a more ornamental and horizontal development but with the return of the original chord the improviser also returns to his initial

remaining but the path stricken by twilights, alone. / In the infinity of the sand its flight (defeat), (for, to) in the valley of the night its (his) flight (defeat), and salt once again, / Are now nothing but chalices, encircling the stem of these seas, where delight is endless for me. / And what can be said of the Ocean, other than that it awaits.'

11 'I have touched this traveller's tree, which I transplanted in that other season of Lent. Its branches swept by hurricane Dean. I speak gently to it. In the flash of a week, it has put out new pale green leaves. I don't give it orders, it borrows from me and gives to me. This is opposite the Diamant rock.' 
set of musical elements, sometimes lingering over long-held notes. The almost classical clarity and balance of Miles Davis's phrasing are sometimes disturbed in the course of the chorus as a whole by chromaticisms and anticipations drawn from blues music. Despite these irregularities, which slip in almost imperceptibly, Davis's sobriety is in contrast to John Coltrane's vehemence and baroque illuminations. It also differs from the bluesy truculence of Cannonball Alderley who follows them both.

Aesthetic rhythm most often occurs as the extended repetition of a beat or group of beats. This regularity characterizes dance music as well as metric poetry. Towards the end of his career Miles Davis was particularly fond, at least in his recordings, of pre-programmed rhythms. He expressed a preference for rock drummers who were, in his view, more rigorous than jazz drummers. On the topic of tempo and arrangement, he commented, 'Music is about timing and getting everything in order. It can sound good, even if it is Chinese, as long as the right things are in place' (Davis and Troupe, 1989: 396). This taste for perfectly regular rhythmics finds expression in his use of drum machines, that is, synthesized and electronically programmed percussion. The track 'Splatch' from the album Tutu (Davis, 1986) exemplifies this obsession with an almost mechanical precision while reflecting a general trend in 1980s funk rock.

The actress Sophie Bourel, who has performed many readings of Glissant's poetry, evokes in discussion rap music with respect to Grands chaos. For his part, the stylistician George Molinié also detects a 'forte structuration rythmique' [strong rhythmic construction] (Molinié, 1999: 142) in Glissant's poetry as evidenced by the following lines:

Ras du sel de mai, cayali

Qui scellait étoile en midi

Sa voyance est de plume folle

Il s'est noyé dans un mécrit

D'ombre boit durci, sucrier

Nom de cris plus que doux mis

A tout chemin inachevés

Nous avons garé son dédit. ${ }^{12}$

(Glissant, 1994: 403)

12 'Maytime salt level, green heron / Who sealed up the star in noon / Its clairvoyance is feather mad / It has drowned in a de-write // Of shadow sips hardened, sugarbird / Name of more than sweet calls set / On all paths unfinished / We have sheltered its broken promise.' 
In this extract from Grands chaos the rhythm of the octosyllabic line is strengthened by the rhymes, by the versification without enjambement and a syntactic and lexical parallelism between the two verses. These both begin with the name of a bird in apposition and conclude with a proposition in the perfect tense.

Such a strongly rhythmic style of writing, whatever its power, does not, however, reflect the entire rhythmic complexity of Glissant's writing any more than the pre-programmed rhythms on the album Tutu or the trumpet player's brief remarks on tempo encapsulate the latter's understanding of rhythm. Poet and musician take equal pleasure in building complex structures where order and disorder are mixed, where 'la mesure et la démesure' [moderation and excess] (Glissant, 1956: 25), to borrow Glissant's expression, are at work. ${ }^{13}$ These can be juxtaposed, for example, in Un Champ d'Iles. This collection is composed on the one hand of seven prose poems. The poems contain long phrases whose constituent parts sometimes appear to be produced one by one with no obvious links: 'Tourmentes, feu marin, étendues sans pitié: ce sont les hautes houilles, parfois le vent qui tout doux avive tout doux surprend le cœur et l'empanache; ce sont meutes du vent qui dévolent des mains, vers la coulpe et l'accomplissement du gravier'14 (Glissant, 1994: 55).

At other times the poet accumulates conjunctions.

Son silence est de vous appeler à ce feuillage de grandeur où naissent la mer, et les continents après elle, et toutes saveurs réparties sous le couteau de la lumière, les nappes spectrales du silence, buses et blancheurs du cri, et toute chose épanouie vers son île quotidienne, ouverte hélante, et secrètement close, et muette autant qu'une splendeur. ${ }^{15}$ (Glissant, 1994: 59)

The breadth and complexity of these lines, combined with a wealth of markers of expression (exclamation marks, question marks, apostrophe), produce the

13 La mesure also denotes musical time (in the sense of time signature, beating time, playing in time) here providing an additional layer of meaning to the two terms.

14 'Torments, marine fire, pitiless expanses: they are the high swells, sometimes the wind which quite gentle stirs up quite gentle surprises the heart and bedecks it with plumes; they are hounds of the wind which unfly from your hands, towards guilt and the completion of the gravel.'

15 'Its silence is to summon you to these leaves of grandeur where the sea is born, and the continents after it, and all flavours spread under the knife of the light, the ghostly layers of silence, buzzards and whiteness of the cry, and every single thing blooming towards its usual island, open calling, and secretly closed, and as silent as a splendour.' 
effect of a musical recitative, that is to say, extended speech that follows a melodic line without the constraint of a regular beat. These fragments of prose contrast with a hypnotic series of forty-seven octosyllabic quatrains. Throughout the series, the poet employs a large number of repetitions while the motif of percussion is also repeated thematically:

C'est là que dorment les tam-tams

Dormant ils rêvent de flambeaux

Leur rêve bruit en marée

Dans le sous-sol des mots mesurés ${ }^{16}$

(Glissant, 1994: 65)

La mesure and la démesure appear in succession but they may also be combined. For example, in 'Promenoir de la mort seule' Glissant again makes use of octosyllabic verse but this regularity is overturned by a mode of discourse which is sometimes on the verge of disintegration:

La baie triste n'a pas bougé

Sur un lac de roses, jonchée

De morts pâlis dans le rosier

Baie funèbre elle est demeurée

La rive hésite la mer passe

Les barques sont laveuses d'eau

Noir est le sable, la couleur

Est évidente dans ce lieu. ${ }^{17}$

(Glissant, 1994: 89)

In 'Pour Mycea', prose fragments are to be found juxtaposed with free verse where brief series of decasyllabic or alexandrine lines sometimes surface. The dream-like fragmentation of the discourse is counterbalanced by the repetition of images (night, hearth, water, day) which express the movement of the island to the rhythms of the cosmos.

This ambivalence between recitative and dance is also to be found in the music of Miles Davis. The blending of the solo line with the drums and, more broadly, with the rhythm section was one of the driving forces behind the different instrumental combinations directed by the 'sorcerer'. The trumpet

16 'It is there that the tom-toms sleep /As they sleep they dream of torches / Their dream sounds as a tide / In the cellar of regular words.'

17 'The sorrowful bay has not moved / On a lake of roses, strewn / With whitened dead in the rosebush / Funereal bay it remains // The shore hesitates the sea passes / The boats are washing the water / Black is the sand, the colour / Is apparent in this place.' 
player's incisive execution, which comes close to that of guitarists such as Wes Montgomery or George Benson, allows him to join in the rhythmic energy of his accompanists. It is this sharpness of style which is to be heard in the chorus of 'Budo' on the album Birth of the Cool (Davis, 1949) or on the title track of Spanish Key (Davis, 1970).

On occasion, however, Miles Davis establishes a rhythmic pattern which is independent of that of his rhythm sections and closely resembles a flow of words. At these moments, for instance in the chorus of 'Masqualero' on the album Sorcerer (Davis 1967), he invites a double perception in the listener. On listening to the soloist, the beat at times seems suspended by the curve of a minute inflexion or by an apparently endless parasitic sound. At the same time, the rhythm section makes us hear the beat as a movement which is born out of the power of the trance and of dance.

Clearly, these two modes of relation are inextricably bound up with each other in Davis's choruses. The musician draws his partners into a dialogics of la mesure and la démesure, whose intensity culminates, in my view, with his second quintet (with Tony Williams, Herbie Hancock, Ron Carter and Wayne Shorter). As Franck Bergerot remarks with regard to the album Nefertiti (Davis, 1967), the different performers in the rhythm section enter and then fall silent, divide the tempo and pull it apart in unpredictable ways (Bergerot, 1996: 98). The wind instruments sometimes act as accompanists to a rhythm section which is constantly generating new patterns. Tony Williams's drumming sums up this rhythmic aesthetic, being anchored in the power and physicality of the rhythmic idiom of black music described by Alain Locke while developing in parallel, by means of his cymbal playing in particular, an exploration of tone also to be found in the experimentation of a composer such as Edgar Varèse.

The complex rhythmic structures to be found in the work of Miles Davis, as in that of Glissant, lead us to another figure common to both: the spiral. This figure combines the return to an initial point (repetition), with the distancing of that same point (difference). In his compositions, which in the event are not very numerous, as in those of his colleagues, Davis favoured the short and repetitive harmonic sequences which would become emblematic of jazz rock. These repetitions, far from being restrictive or appearing obsessive, open up the space of freedom available to the improvisers. It is striking to hear how far the repetitive and circular chord sequence of 'Blue in Green' (Davis, 1959) inspires the musician to produce one of his most lyrical solos, however brief. Miles Davis's fascination with circular forms, which can be traced on the album So What (Davis, 1959), is explicit in the titles of the first two tracks of Miles Smiles (Davis, 1966), called respectively 'Orbit' and 'Circles'. 
In his improvisations, Davis's method is often to repeat a short phrase which is then developed and transposed along the way. This process of spiral development, which can be heard clearly in many of the numbers he composed and improvised for the film Ascenseur pour l'échafaud (Davis, 1957), is influenced by the poetic form employed by blues singers. The poet Langston Hughes often used this form for expressive purposes. In Miles Davis, the form is systematized, autonomized and expanded. Spiral repetition is also to be found on a larger scale. In 'It's About That Time' (Davis, 1969), sustained by the same rhythmic and harmonic ostinato, Miles Davis takes the first chorus then hands over to the guitar and the saxophone. His return brings about an unleashing of energy. Tony Williams, who until this point has been happy to produce a continuous drum beat based on the Charleston, lets his contained energy spill out. Here, repetition and the return to the point of departure are liberating rather than restricting forces, forming a spiral, not a closed circle.

We can also see this larger spiral form in the epic poem Les Indes. The poem opens beside the sea: 'Nous sur la plage, il nous est fait licence de nous assembler à la proue de la voix, de crier, Sur la plage' [We on the beach, we are given permission to gather together at the prow of our voices, to call out, On the beach] (Glissant, 1994: 112). Moved by 'l'air lyrique des départs' [the lyric melody of departures], the navigators 's'élancent sur l'Atlantique à la recherche des Indes' [set out on the Atlantic in search of the Indies] (Glissant, 1994: 109). After discovery comes conquest. Then massacres and plunder, followed by deportation, chains and battles for freedom. The epic poem ends with an evocation of the town where desire was born: Genoa. Far-sighted men have not forgotten 'la première plage' [the first beach], but they find themselves confronted by a new Indies: 'Voici la plage, la nouvelle. Et elle avance pesamment dans la marée' [Here is the beach, the new one. And it moves forward heavily in the tide] (Glissant, 1994: 165). This new horizon is not one of conquest but of Relation. The return to the open sea is no longer an invitation to the conquest of new territories but to that of its own gaze which is now turned towards the face of the Other. The call is no longer that of a 'nomadisme en flèche' [arrow-like nomadism] but of a 'nomadisme circulaire' [circular nomadism] (Glissant, 1990: 30).

With regard to his essays, Édouard Glissant also speaks of 'écho recomposé' and of 'redite en spirale' [recomposed echo, spiral repetition] (Glissant, 1990: 28). Concepts, or rather thoughts, are repeated and reformulated from one book to the next. Thus, on the subject of Relation, the poet writes in L'Intention poétique: 'la terre a cessé d'être essence, elle devient Relation' [the earth is no longer essence, it becomes Relation] (Glissant, 1969: 190). In Le Discours antillais, Relation is 'le feu majeur des poétiques à venir' [the 
principal light of future poetics] (Glissant, 1981: 19). It is 'l'effort sans limite du monde' [limitless effort of the world] in Poétique de la relation (Glissant, 1990: 186). In the recent Philosophie de la relation, the poet writes: 'Divination et prescience de la Relation, qui s'annonce, acceptons-en l'invitation partout incertaine, avec l'alliance des continents et des archipels' [Divination and foreknowledge of Relation, which is on its way, let us accept its invitation which is everywhere uncertain, along with the union of continents and archipelagos] (Glissant, 2009: 79). These changes in formulation, which are mostly metaphorical, call on us to allow the ideas they contain to move through our imaginations and open up ever-wider spaces within them.

The combination of repetition and the opening up of new vistas would appear to be an aesthetic ideal for the writer. As he himself puts it,

Je ne sais pas à quel âge, dans mon très jeune temps, j'ai rêvé d'avoir développé un texte qui s'enroulerait innocemment mais dans une drue manière de triomphe sur lui-même, jusqu'à engendrer au fur et à mesure ses propres sens. La répétition en était le fil, avec cette imperceptible déviance qui fait avancer. Je m'ennuie encore de ne pas retrouver l'enhâlement tant tourbillonnant qu'il créait, qui semblait fouiller dans une brousse et dévaler des volcans. ${ }^{18}$ (Glissant, 2005: 20)

Through breathing, through la mesure and la démesure, and in the figure of the spiral, we can see that the work of these two creators, each in its own way, is centred on rhythm. At the end of this journey through the rhythms of poetry and jazz, we can perhaps arrive at Nelson Goodman's definition of style as 'those features of the symbolic structure of a work that are characteristic of author, period, place, or school' (Goodman, 1978: 35). Style is thus at once a part of what is expressed and the means by which this part is expressed. We can also come to Glissant's definition of rhythm as a 'levier de conscience' [a lever of awareness] (Glissant, 1969: 216).

Miles Davis and Édouard Glissant both transform rhythm into a lever of awareness which opens up space. The desire for space was a constant preoccupation for the musician. His disagreements with Thelonious Monk and his shifts towards modal jazz and then fusion music all result from

18 'I don't know at what age, in my extreme youth, I dreamed that I had developed a text which would coil innocently but in a powerful triumphant way around itself, to the point that it would create its own meanings along the way. Repetition would be the guiding thread, with that imperceptible deviation which pushes you onward. I am still frustrated at my inability to rediscover the hot dry whirling wind it created, which seemed to blast through bush and to flow down volcanoes.' 
this same preoccupation. In fact, Davis, with his colleague John Coltrane, opened up the musical space of the twentieth century well beyond the limits of jazz. Miles was one of the prime movers in the renewal of improvisation in Western music. His liberating influence is to be found in many types of music from rock to contemporary music, not to mention French chanson and the revival of ancient music. It is no longer possible to perform Bach in the same way once you have heard Miles Davis's phrasing.

Likewise, for readers sensitive to Glissant's writing style and philosophy, the expansion of their imaginations and perceptions of the world brought about by his works is an almost physical experience. Glissant's words liberate those who have ears to hear, making them reconsider their own existence. The cascades of rhythms and metaphors carry them towards the foreknowledge of this complex and unexpected new region of the world. The quest for a space without limits is to be heard in many of the trumpeter's choruses, for example that of 'Footprints' (Davis 1966). It can equally be heard in the speech which concludes Les Indes:

Ô course! Ces forêts, ces soleils vierges, ces écumes

Font une seule et même floraison! Nos Indes sont

Par delà toute rage et toute acclamation sur le rivage délaissées,

L'aurore, la clarté courant la vague désormais

Son soleil, de splendeur, mystère accoutumé, ô nef,

L'âpre douceur de l'horizon en la rumeur du flot,

Et l'éternelle fixation des jours et des sanglots. ${ }^{19}$

(Glissant, 1994: 109)

A performance of African dance and music was the inspiration for Miles Davis's modal revolution. The space he offers thus finds its origin in the wound created by a lost and forbidden space. As Glissant says in 'La Barque ouverte', the trauma of the slave trade can be brought to a close in 'connaissance du tout' [knowledge of the totality]. 'Le gouffre est aussi projection et perspective d'inconnu. Par delà son abîme, nous jouons sur l'inconnu' [The abyss is also a projection and view of unknown things. Beyond its depths, we are playing on the unknown]. 'Nos barques sont ouvertes, pour tous nous les naviguons' [Our boats are open, for everyone we sail them] (Glissant, 1990: 21). The extraordinary power represented symbolically by the style of these

19 'Oh race! These forests, these virgin suns, these foaming waves / Are part of one and the same flowering! Our Indies are / Beyond all anger and all acclamation on the shore abandoned, / Dawn, light running across the waves henceforth / Its sun, of splendour, usual mystery, oh vessel, / The bitter sweetness of the horizon in the crashing of the waves, / And the eternal binding of the days and of tears.' 
two creators thus derives from a common history, from a movement towards 'l'aurore' [dawn] and 'la clarté courant la vague' [light running across the waves], which was born out of the darkness of the mutilated ship's hold. The power of these two rhythms cannot, however, be reduced to this shared history. It is the reflection of two creative forces who transcend their century and who can be neither explained nor summed up except, perhaps, when we remember that the trumpet player was born one year after a hurricane, and the poet during the onset of a volcanic eruption by Mount Pelée.

\section{Works Cited}

Backès, Jean-Louis. 1994. Musique et littérature. Paris: Presses universitaires de France.

Barthes, Roland. 1953. Le Degré zéro de l'écriture. Paris: Éditions du Seuil. English translation by Annette Lavers and Colin Smith, Writing Degree Zero, 1977 [1967]. New York: Hill and Wang.

Bergerot, Franck. 1996. Miles Davis, Introduction à l'écoute du jazz moderne. Paris: Éditions du Seuil.

Britton, Celia M. 1999. Édouard Glissant and Postcolonial Theory: Strategies of Language and Resistance. Charlottesville and London: University of Virginia Press.

-. 2008. 'Langues et langages dans le Tout-Monde'. In Samia Hassab-Charfi and Sonia Zlitni-Fitouri (eds), Autour d'Édouard Glissant: lectures, épreuves, extensions d'une poétique de la relation. Pessac: Presses universitaires de Bordeaux: 235-45.

Davis, Miles, and Quincy Troupe. 1989. The Autobiography. New York: Touchstone. Glissant, Édouard. 1956. Soleil de la conscience. Paris: Éditions du Seuil.

—. 1969. L'Intention poétique. Poétique II. Paris: Éditions du Seuil.

—. 1981. Le Discours antillais. Paris: Éditions du Seuil.

—. 1990. Poétique de la relation. Poétique III. Paris: Gallimard. English translation by Betsy Wing, The Poetics of Relation, 1997. Ann Arbor: University of Michigan Press.

-. 1993. Tout-Monde. Paris: Gallimard.

—. 1994. Poèmes complets. Paris: Gallimard.

—. 2001. Visite à Édouard Glissant. Edited by Gérard Cléry. Paris: Caractère.

- 2005. La Cohée du Lamentin. Poétique V. Paris: Gallimard.

-. 2006. Une nouvelle région du monde. Esthétique I. Paris: Gallimard.

—. 2009. Philosophie de la relation: poésie en étendue. Paris: Gallimard.

Goodman, Nelson. 1978. Ways of Worldmaking. Indianapolis, IN: Hackett.

Lalande, André. 1926. Vocabulaire critique et technique de la philosophie. Paris: Presses universitaires de France. 
Locke, Alain Leroy. 2009. Le Rôle du nègre dans la culture des Amériques. Ed. by Anthony Mangeon. Paris: L'Harmattan.

Mangeon, Anthony. 2004. 'Lumières noires discours marrons'. Doctoral thesis. Université de Cergy Pontoise.

Molinié, Georges. 1999. 'Pour une poétique d'Édouard Glissant'. In Jacques Chevrier (ed.), Poétiques d'Édouard Glissant. Paris: Les Presses de l'université Paris-Sorbonne: 141-45.

Sauvanet, Pierre. 2000. Le Rythme et la raison. Paris: Kimé.

Souriau, Etienne. 1990. Vocabulaire d'esthétique. Paris: Presses universitaires de France.

\section{Discography}

Davis, Miles. 1949. Birth of the Cool. Capitol (rel. 1956).

-. 1959a. Kind of Blue. Columbia.

-. 1959b. So What. Columbia.

—. 1966. Miles Smiles. Columbia.

-. 1967. Sorcerer. Columbia.

-. 1968. Nefertiti. Columbia.

-. 1969. In a Silent Way. Columbia.

-. 1970. Bitches Brew. Columbia.

-. 1986. Tutu. Warner. 


\title{
Creolizing Jazz, Jazzing the Tout-monde: Jazz, Gwoka and the Poetics of Relation
}

\author{
Jerome Camal
}

In a recent article in Black Music Research Journal, French sociologist Denis-Constant Martin proposed that Martinican writer Édouard Glissant's concept of creolization could help reconcile jazz's historical roots as an African American music with its recent universalization (Martin, 2008). Martin thus joined a growing group of scholars who use the concept of creolization in globalization studies in order to emphasize the fluid and unstable nature of culture. Meanwhile, scholars in postcolonial studies have embraced creolization's potential to celebrate the creative ingenuity of 'subaltern and deterritorialized peoples' and its power to subvert 'older notions of cultural dissolution and disorganization' (Khan, 2007: 237-38). However, a number of anthropologists have expressed reservations about this trend. Arguing that the historical process of creolization in the Caribbean has been fundamentally different from contemporary processes of globalization, these scholars advocate that creolization not be divorced from its original historical and geographic contexts (see Mintz, 1996 and 1998; Palmié, 2006 and 2007; Khan, 2007 for examples). Prompted by these debates, the present chapter tests Martin's postulate through a study of US saxophonist David Murray's collaboration with Guadeloupean musicians. Drawing on written, ethnographic and musical sources, I compare Martin's understanding of Glissant's créolisation with the meaning of creolization for the musicians involved in the Creole Project. ${ }^{1}$ I demonstrate that 'creolization' - and

1 Throughout this chapter, I use the French 'créolisation' to refer specifically to Glissant's theory, while its English translation refers more broadly to the various 
its related terms 'Creole' and 'créolité' - continue to hold specific and disputed meanings in Guadeloupean society, thus problematizing their wider application as concepts capable of describing global processes of cultural exchange or identity formations.

\section{Jazz and Glissant's Poetics of Relation}

In his thought-provoking article, Martin seeks theoretical answers to the following questions: How can we account for the spread of jazz - and other African American or Afro-Caribbean musics - throughout the world and their transformation into countless regional variants while also acknowledging the central contribution of African American musicians? What makes jazz and other forms of African American music universal? In using terms like 'universal' or 'universalization', Martin does not suggest that jazz and black musics are played and received in the same way throughout the world but rather that there are few places, if any, where black musics have not been embraced, appropriated or blended with local traditions. Although Martin's concern with universalism echoes Glissant's, the sociologist seems to be reaching for something more attuned to what ethnomusicologist Thomas Turino calls 'cosmopolitanism' (Turino, 2000: 7-11). Unlike terms such as 'global' or 'universal', which suggest the unrestricted diffusion of cultural objects and practices throughout the world and evoke fears of homogenization, cosmopolitanism admits that transnational cultural objects and practices are often adopted only by a segment of each local population and subjected to varying degrees of local interpretation and appropriation. ${ }^{2}$

In order to answer the questions outlined above, Martin proposes a theoretical shift by introducing Glissant's concept of créolisation. Philosopher, novelist and poet, Glissant developed his theory of Relation, in which créolisation plays an important part, through a variety of literary genres. A thorough exploration of Glissant's theory would exceed the confines of this chapter and for our purposes it is sufficient to focus on Martin's interpretation of Glissant's writings. Glissant consistently presented jazz as a musical embodiment of créolisation, thus justifying Martin's introduction of the term in jazz studies. In Le Discours antillais, Glissant asserts that jazz and other forms of Afro-Caribbean musics are products of the plantation system. He

linguistic and anthropological theories dealing with the emergence of syncretic cultural formations in the Caribbean and throughout the world.

2 Several ethnomusicologists have followed Turino's lead to explicate the process by which Caribbean musics participate in cosmopolitan loops. See Largey, 2006; Rommen, 2007; and Dudley, 2008. 
further argues that jazz differs from other forms of black music because, unlike musics such as biguine, it transformed itself once the plantation system collapsed in the late nineteenth century. ${ }^{3}$ According to Glissant, as the African American community experienced urbanization, industrialization and modernization, the emergence of new jazz styles assured that the music remained relevant to the experiences of the community who created it. He concludes that 'l'universalisation du jazz provient de ce qu'en aucun cas elle n'est une musique "en l'air", mais l'expression d'une situation donnée' [the universalization of jazz comes from the fact that it has never existed in a vacuum but rather is the expression of a particular situation] (Glissant, 1997: 383). ${ }^{4}$ Beyond the apparent contradiction, Glissant proposes that jazz's capacity to adapt to specific situations made its universal distribution possible.

Quoting from Tout-monde and Traité $d u$ tout-monde, Martin explains that jazz offers a sonic trace, a way to transmit memory, history and world vision (Martin, 2008: 107-08). However, Martin does not address the other meaning of trace, one familiar to those who have roamed the mountains of Martinique or Guadeloupe, where trace refers to a path. This second meaning, to which Glissant often alludes, is important in understanding the role of the trace in putting people and cultures in relation with one another. The trace not only looks back, it also leads forward. Glissant offers the 'pensée de la trace' as a force capable of opposing the 'pensée de système' [systematic thoughts] or 'systèmes de pensée' [systems of thought] that have characterized Western colonialism (Glissant, 1996: 17; 1997b: 18). Martin's omission of this local reference divorces Glissant's theory from its specific geographic (and political) context, an important point to which I will return later.

Martin breaks down Glissant's theory of Relation into four stages: métissage, créolisation, Relation and the Tout-monde [whole world]. While there is no single English translation for métissage, Glissant used the term 'cross-breeding' in an address at the University of Oklahoma (Glissant, 1989: 561). In other situations, 'cross-fertilization' seems equally appropriate (see, e.g., Glissant, 1996: 19). Martin explains that métissage 'created the conditions from which Relation spread, and assumes that it prevents any negative otherness' (Martin, 2008: 108). In other words, the recognition

3 Glissant's assertions are problematic since the emergence of both jazz and biguine in the late nineteenth century, and their subsequent growing popularity in the twentieth, were intrinsically linked to emancipation, urbanization and industrialization.

4 This and all other translations are by the author of this chapter unless cited otherwise. 
of cultures of métissage negates the existence of 'pure' cultures (Glissant, 1997a: 428-29) and therefore provides a safeguard against essentialism and intolerance and opens up new spaces in which Relation can grow.

Martin defines creolization as 'unlimited métissage', a definition Glissant proposed in Poétique de la relation. However, Glissant later drew a distinction between métissage and créolisation. In Introduction à une poétique du divers, the philosopher explained that the results of métissage can be predicted whereas créolisation introduces unpredictability in processes of synthesis (Glissant, 1996: 19). Glissant further stipulates that in order to be truly successful, créolisation must combine cultural elements 'équivalents en valeur' [of equivalent value], although he does not explain what this entails. In situations where creolization took place between elements of disparate value, it only took effect in a 'mode bâtard' and a 'mode injuste' [hybrid and unjust mode] (Glissant, 1996: 17). In the Western Hemisphere, where creolization is intrinsically linked with slavery, artistic movements such as négritude or the Harlem Renaissance have provided the necessary correction to put African and European culture on a more equal footing (Glissant, 1996: 17-18).

Successful créolisation puts people and cultures in Relation, a phenomenon that Glissant observes throughout the world. For Martin, Glissant's poetic of Relation offers a system that addresses 'both the elusive globality of a chaotic world and the "opacity" (that is to say the irreducible specificity) of the place one is from' (Martin, 2008: 109). The world thus becomes the 'Tout-monde' which can be translated as both 'whole world' and 'everyone', depending on whether one chooses to focus on the French or Creole meaning. ${ }^{5}$ Glissant envisions the Tout-monde as both 'multiple and one', a space where specificity and universality are reconciled. Martin concludes: 'Within this framework, there is indeed no contradiction between the permanent centrality of jazz and its universalization' (Martin, 2008: 110). I would now like to examine this assertion within the context of David Murray's Creole Project, as his collaboration with Antillean musicians is often referred to in the jazz press.

\section{Gwoka and Guadeloupean Politics}

David Murray, a longtime Paris resident, met Guadeloupean percussionist Klod Kiavué at the Banlieues Bleues festival in 1995. Within two years, the two men had organized a collaborative project which initially linked US jazz musicians with musicians from Martinique, Guadeloupe and Cape Verde. This collaboration resulted in a first album entitled simply Creole. Ultimately, this broad exploration of Creole music proved unwieldy, forcing Murray and

5 In French Creole, 'tout moun' means 'everybody'. 
Kiavué to limit the scope of their project. Kiavué proposed that they record an album focused on compositions by Guadeloupean gwoka singer Guy Konket. Thus was born the group David Murray and the Gwo-Ka Masters. Konket only spent two years touring with the group, but Murray and Kiavué have since continued to look for ways to blend North American jazz with Guadeloupean gwoka.

Definitions of gwoka vary from the poetic to the specific. Ethnomusicologist Frederic Negrit writes that gwoka is 'l'ensemble de musiques, danses et chants rythmés, d'origines guadeloupéenne, à base de percussions, orchestré par deux batteurs au minimum, œuvrant sur deux tambours de fonctions différentes' [the ensemble of rhythmic musics, dances and songs of Guadeloupean origins, based on percussions and orchestrated by a minimum of two drummers, each with a separate function] (Negrit, 2004: 193). In contrast, instrumentalist, composer, and educator Christian Dahomay declares that gwoka is 'ce qui reste quand on a tout oublié' [what's left when you have forgotten everything] (Dahomay, 1997: 18). Most commonly, but not exclusively, gwoka refers to a set of dances accompanied by an ensemble of barrel-shaped, singleheaded drums, themselves called gwo ka or ka. ${ }^{6}$ Two boula, the lowest of the drums, play one of the several rhythmic ostinati that underpin most gwoka performances. A single, higher-pitched drum called makè improvises in coordination with the movements of the dancer in front of him, or occasionally her. Traditional gwoka is a participatory music, meaning that there is not a clear delineation between audience members and performers. ${ }^{7}$ For instance, singing is responsorial between a song leader and a choir composed of members of the audience. Gwoka is traditionally performed during swaré léwòz, outdoor celebrations held on Friday or Saturday nights.

Owing to its association with slavery, gwoka has historically been stigmatized in Guadeloupean society. This was especially true between the 1848 emancipation declaration and the mid-twentieth century, a period which saw the rise of quadrille and biguine, two musical genres that mixed European and Creole instruments and whose popularity cut across socioracial divisions. During this time, the coloured middle-class in Guadeloupe and Martinique endeavoured to assert its political power against the white plantocracy, an effort that culminated in the 1946 law of départementalisation. Unfortunately, the new political status failed to mitigate the effects of the collapsing sugar industry in the French Antilles, fuelling widespread social unrest and the growth of separatist movements on both islands.

6 There is no standardized spelling for 'gwoka'. The spellings 'gwo ka' and 'gro $k a^{\prime}$ are also acceptable.

7 I borrow the concept of 'participatory music' from Turino, 2000: 47-58. 
In Guadeloupe, gwoka became strongly associated with separatist activism from the late 1960s onward. Influenced by Marxist-Maoist ideology, Guadeloupean nationalists within organizations such as the Groupe d'organisations nationales de Guadeloupe (GONG), the Association générale des etudiants guadeloupéens (AGEG) and the Union pour la libération de la Guadeloupe (UPLG) articulated a vision of Guadeloupean national identity based on the cultural practices of the island's rural lower-class population. Throughout the 1970s and 1980s, they campaigned to legitimize the Creole language and to revitalize gwoka. ${ }^{8}$ Guadeloupean nationalist intellectuals under the guidance of guitarist Gérard Lockel proposed to modernize gwoka by performing it onstage with European and North American instruments such as guitar, flute or drum set. This effort to bring a rural participatory music to the stage is consistent with postcolonial modernist-reformist strategies in other locations that seek to adapt local music to cosmopolitan aesthetics. ${ }^{9}$ As Turino points out, there is an inherent tension in nationalist movements that attempt both to participate in cosmopolitan formations and to highlight their local specificity. In Guadeloupe, Lockel's gwoka modènn [modern gwoka] aimed to resolve this tension by dictating that instrumental gwoka should be strictly based on a set of seven rhythms commonly played in swaré léwòz and on a distinctive non-tonal scale. ${ }^{10}$

Since the 1970s, the gwoka (drum) has become a marker of Guadeloupean specificity in other musical genres such as zouk, a form of popular music that emerged in the French West Indies in the 1980s (Guilbault, 1993: 32-35). Today, nationalist ideology continues to inform the discourse of many gwoka musicians, with those most closely aligned with its orthodoxy insisting that gwoka is an atonal music and viewing any attempt to incorporate elements of European tonal harmony into the music as a severe threat to its integrity.

8 The nationalist movement's cultural platform was outlined in Association générale des etudiants guadeloupéens, 1970. Dany Bébel-Gislert (1989) offers an alternative view of the issue of language and national identity. Ellen Schnepel (2004) explores the links between politics, identity and the Creole language in Guadeloupe. As early as the 1980s, Guadeloupean ethnographer Marie-Céline Lafontaine $(1983 ; 1988)$ criticized what she saw as the nationalist movement's excessively narrow focus on gwoka as the sole musical icon of Guadeloupean identity.

9 For more on modernist-reformism in music, see Turino, 2000; Largey, 2006; and Dudley, 2008.

10 Lockel's gwoka scale is based on a succession of whole steps and minor thirds and takes nine octaves to loop upon itself. See Lockel, 1978; 1981. 


\section{David Murray and the Gwo-Ka Masters: The Problematic of Creolization}

The liner notes to David Murray's Creole Project CDs reveal that issues of ethnic, racial and cultural identities loom large over this collaboration. References to créolisation, créolité and Afrocentrism abound. For example, the liner notes to the album Creole include a short endorsement by Gérard Lockel, who appeared on two tracks from this album. In his text for Creole, and in contrast to his unremitting nationalist convictions, the guitarist defines himself as an 'Afro-American musician' born in a colony, a condition he equates with créolité. Echoing Glissant, he states that Caribbean musics are self-sufficient and therefore hold international appeal. But he also insists that Afro-American musicians distinguish themselves because their 'authentic' musics are free from the bounds of tonality that characterize 'occidental' music (Murray, 1998). In another example, journalist Jacques Denis wrote in his liner notes for the album Gwotet,

Ni noir, ni blanc, cette internationale créole est à l'œuvre aujourd'hui de par le monde, bande-son bien réelle de ce que Édouard Glissant nomme si justement la créolisation, processus historique qui fait surgir d'une partie de l'Atlantique Noir défini par Paul Gilroy une nouvelle identité rhizomatique, par nature complexe et par essence irréductible aux schémas de l'historiographie classique. Un autre homme, le Brésilien Tom Zé, a trouvé un bon mot en forme de néologisme pour traduire cette transformation continue: unimultiplicité. ${ }^{11}$ (Murray, 2004: 5)

Lockel's unorthodox definition of créolité and his rejection of hybridization with occidental music directly contradict Denis's embrace of creolization and 'unimultiplicity'. It is therefore important to unravel how the musicians involved in the Creole Project understand words such as 'Creole', 'creolization' and 'créolité'. I want to make clear at this point that the musicians I interviewed often conflated all three terms to an extent that would most likely disturb Édouard Glissant and the authors of the seminal Éloge de la créolité (Bernabé, Chamoiseau and Confiant, 1993). My goal

\footnotetext{
11 'Neither white nor black, the international Creole movement is extending its reach across the world today, like a soundtrack accompanying what Glissant has called "Créolisation". This historical process is giving form to a new and necessarily complex identity, one impervious to the categories and structures of traditional historiography. This identity is in permanent flux, a flux that Brazilian Tom Zé has summed up well in his neologism unimultiplicity.' Translation by Anna-Louise Milne.
} 
here is not to address the theoretical distinctions of these terms but rather to expose their meaning and relevance to a specific group of musicians.

I first contacted David Murray in December 2006. During the course of the interview, Murray expressed interest in créolité but rejected the possibility that anything like it could have emerged in the United States. The saxophonist argued that slavery in the United States had resulted in a more profound type of cultural erasure than in the Francophone Caribbean. Under these conditions, Murray concluded, it has been impossible for Creole languages to develop and therefore a concept like créolité did not really apply to North America (recorded interview, 2006). In Guadeloupe, Klod Kiavué confirmed Murray's conclusions:

Les musiciens américains, ça ne les concerne pas. Eux, ils veulent défendre un truc, ils sont plus proches de Césaire que de Chamoiseau. [...] Ça c'est clair, de Fanon, Césaire que de Chamoiseau. Parce qu'ils voient pas l'intérêt, pour eux en tant que Noirs américains, [de] cette histoire de créolité. ${ }^{12}$ (recorded interview, 2007)

Kiavué also expressed personal reservations about the concept of créolité. Speaking of his work with Murray, he stated, 'Le truc de la créolité, ça a toujours était un problème pour cette musique-là. Parce que tout le monde n'adhère pas [...] Moi j'adhère pas.' He added,

Le mélange, un gars comme Lockel, il te dit aussi: 'Si tu es tout le monde, tu n'es rien du tout.' Tu vois un peu, l'idée c'est un peu ça, dire que, bon, nous, on est le monde. Si tu es le monde, t'es rien du tout parce que, jusqu'à maintenant, en Guadeloupe, l'ethnie noire a créé le gwoka, l'a développé et n'a jamais eu droit à la parole. Jusqu'à maintenant, dans l'histoire de la Guadeloupe, l'ethnie noire n'a jamais eu réellement droit à la parole, tu vois, à part de par la musique. ${ }^{13}$ (Recorded interview, 2007)

12 'American musicians are not concerned with it. They want to defend something closer to Césaire than Chamoiseau. [...] That's certain, closer to Fanon, Césaire than Chamoiseau. As American musicians, they fail to see anything of interest in this story of créolité.'

13 'This thing of créolité, it has always been a problem for this music. Because not everybody embraces the concept. [...] I don't embrace it. Someone like Lockel would tell you: "If you are the world, you are nothing at all." You see, the idea is a little bit like saying that we are the world. If you are the world, you are nothing at all because, up until now, in Guadeloupe, the black ethnicity has created gwoka. They developed it but they were never given the right to speak out. Up until now, in the history of Guadeloupe, the black ethnicity never really had the right to speak out, you see, except through music.' 
Here, Kiavué looks with some suspicion at what the authors of Eloge de la créolité have referred to as their 'spécificité ouverte' [open specificity] (Bernabé, Chamoiseau and Confiant, 1993: 28). Far from welcoming créolité as a potential resolution of the tension between the universal and the specific, Kiavué rejects this unstable and inclusive identity in favour of a more specific identity based on race and nationality, an attitude that reflects the influence of the Guadeloupean nationalist movement of the 1970s. As Richard Burton has explained, Antillean intellectuals from Césaire to Chamoiseau have struggled to 'affirm their difference in the face of [...] the reductive universalism of the whole Jacobin-Republican tradition in France' (Burton, 1995: 141). For this reason, Guadeloupean nationalist thinkers remain suspicious of any universalist claim - including those of Antillean writers such as Glissant - to which they oppose a discourse promoting the specificity of each island's culture.

Not only do many Guadeloupean gwoka musicians reject créolité, they also regard the term 'Creole' with suspicion. Alain Jean - a radio personality, nationalist activist and longtime advocate for gwoka music - explained to me that he refuses to use the term 'Creole' to define a person, preferring to limit the use of the noun to refer to the language. People, he argued, should be referred to as Guadeloupean, Martinican or Caribbean, but not Creole or Antillean (recorded interview, 2009). These terms express a conceptualization of the Caribbean as a group of separate nations, each with its own specific culture. The term 'Caribbean' is preferred over 'Antillean', whose use remains strongly tainted by French colonialism. Likewise, Jean expressed his distrust for the word 'creolization', which he perceived as often emphasizing the primacy of European over African culture. During the course of my research in Guadeloupe, many musicians echoed this attitude, including Kiavué, who once told me, dictionary in hand, that he could not consider himself Creole since the Petit Robert (2006) French dictionary still defined 'créole' as 'personne de race blanche, née dans les colonies intertropicales, notamment les Antilles' [a person of white race born in the tropical colonies, especially in the Antilles].

More than creolization, it is the legacy of the Middle Passage and slavery that generates what Paul Gilroy calls 'diasporic intimacy' (Gilroy, 1992: 193) between the members of the Creole Project. Kiavue stressed the common ground he and Murray found between their respective musical traditions:

En discutant, on se rend compte que le gwoka et le jazz ont les mêmes fondations. Ce sont des musiques, on connaît l'histoire, des musiques de descendants d'esclaves. La seule différence, c'est comme on aime dire, une 
ça a fait le blues du coton, nous on a le blues de la canne. Donc, c'est deux branches différentes. ${ }^{14}$ (recorded interview, 2007)

Later, he elaborated on this idea:

On s'est mis d'accord sur deux choses: c'est que c'est deux musiques rebelles, c'est deux musiques qui ont été créées pour combattre l'esclavage, pour combattre les blancs et c'est des musiques d'improvisation. Donc ça, c'est les deux caractères fondamentaux pour nous où ces musiques-là se rejoignent: deux musiques de revendication et deux musiques d'improvisation. C'est ça qui a été le socle des discussions. ${ }^{15}$ (recorded interview, 2007)

Even if Murray and Kiavué question terms such as 'Creole' or 'créolité', it is conceivable that, beyond their own awareness, something like créolisation is at work in their musical collaboration. On the surface, this seems entirely possible. Murray professes a vision for a new music that goes beyond a superficial juxtaposition of jazz and gwoka. He explained, 'I'm trying to mix jazz with gwoka music, Creole lyrics - but at the source of it, the bottom of it, so that it grows out together' (recorded interview, 2008). For Kiavué, the band is trying to develop a new idiom that is neither jazz nor gwoka and which he sees captured in the neologism 'gwotet', which Murray coined to designate his new musical group, but which also means 'big head' in Creole, as Kiavué humorously pointed out.

The conditions seem poised for what Glissant has imagined as a meeting of cultures of equivalent value. However, in his study of the 'world music' phenomenon, musicologist Timothy Taylor explains that collaborations between Western and non-Western musicians often replicate subordinating structures inherited from colonialism. While Taylor warns us that these hegemonic practices inform even the output of musicians who try to work around them, he leaves some room for more egalitarian collaborations (Taylor, 1997: 39-68, 173-96). It is easy to imagine that the work of Murray and the Gwo-Ka Masters falls into this latter category. David Murray is a versatile musician who has successfully promoted himself in a great variety

14 'As we were talking, we realized that gwoka and jazz had the same foundation. They are both music, we all know the story, they are music that descends from slaves. The only difference, as we like to say, is that one sings the blues of cotton and we have the blues of the sugar cane. So they are two different branches.'

15 'We agreed on two things: that they are rebellious musics, two musics created to fight slavery, to fight the whites and that they are improvised musics. So those are the two fundamental characteristics where these musics meet: two protest musics and two improvised musics. This provided the entire basis for our discussions.' 
of musical contexts. While this collaboration adds to his reputation for eclecticism, it offers little in terms of market visibility or financial reward that he could not achieve with his other projects. On the other hand, percussionists Klod Kiavué and François Ladrezeau claim to have benefited from the collaboration. Through their tours with the Gwo-Ka Masters, they have been able to meet festival organizers, promoters and journalists around the world, and thus bring more attention to their own music. However, these connections have yet to bear concrete professional rewards, and neither Kiavué nor Ladrezeau has gained access to the international touring circuit outside of Murray's outfit.

Murray himself seems to have noble goals for this music. In 2008, the saxophonist explained to me that his goal was to bring greater recognition to gwoka. He stated, 'I told Klod that I'm trying to give gwoka wider recognition so that we can get gwoka to the Grammys. [...] I got a Grammy here for some work I did with McCoy Tyner, but gwoka needs its own Grammy' (recorded interview, 2008). In a 2005 interview with Guadeloupean jazz critic Luc Michaux Vignes, Kiavué explained the value of working with a musician who is invested in developing a financially successful project. For Murray as for Kiavué, the Creole Project's success should translate into the sales of concert tickets and albums. And because the band does sell, the Creole Project has managed to raise awareness about Guadeloupean music in Europe and, to a lesser degree, in the United States. ${ }^{16}$ But at what price?

Semiotician Jean-Jacques Nattiez points out that musical works are polysemic and that their meanings very much depend on the socio-historical context in which these works are produced and received (quoted in Martin, 2008: 117). For Guadeloupean musicians, as for a large portion of the Guadeloupean population, gwoka remains a national and nationalist symbol, a meaning best encapsulated in the phrase 'gwoka sé potomitan a mizik an nou' [gwoka is the central pillar of our music]. While Murray respects the gwoka tradition, he is not limited by this particular historical heritage. He, for example, can ignore the debates which have surrounded Lockel's concept of gwoka modènn. This frees him to transform the music as he sees fit in order to increase its market appeal. For many gwoka musicians in Guadeloupe, this leads to a 'bastardized' form of music, and the musicians who collaborate with Murray are sometimes accused of 'prostituting' the music. Both Kiavué and Ladrezeau have acknowledged this difficult situation during interviews and private conversations.

16 Saxophonist Jacques Schwarz-Bart's recordings (2006; 2008) blending jazz and gwoka have also done much to bring attention to Guadeloupean music in recent years. 
Finally, it seems that no matter how much Murray and the Gwo-Ka Masters would like this to be a collaboration of equals, it simply cannot be. Citing ethnomusicologist Steven Feld, Taylor warns that 'no matter how collaborative and syncretic a musical style sounds, we should always remember the musicians' relationship to the means of production' (Taylor, 1997: 173). In this case, Murray controls every aspect of the recording process and, more importantly, makes all the decisions during mixing and editing. This gives the saxophonist complete control over the band's recorded output.

Over time, the aesthetic of the Creole Project has evolved in revealing ways. The album with Guy Konket (Murray, 2002) was entirely sung in Creole. An educated listener could fairly easily identify the basic gwoka rhythmic patterns in the mix. In addition, Murray based many of his arrangements on previous Konket recordings. The group's latest album offers a disturbing contrast. The musicians recorded in Guadeloupe in 2008 and invited local quadrille accordionist Négoce to join them. Mixing took close to two years. During this time, Murray decided to get rid of the tracks laid down by Négoce. Instead, he solicited blues singer Taj Mahal and US singer Sista Kee to overdub English lyrics based on poems by Ishmael Reed on half the tracks. The result is an album sung almost entirely in English and in which a heavy funk influence masks most of the distinctive Guadeloupean elements. If this collaboration initially augured some of the unpredictable creative results promised by Glissant, it has since come dangerously close to illustrating globalization's homogenizing effects.

\section{Conclusion: Music and Relation as Ideological Processes}

From these observations it seems that Glissant's créolisation has little value in analysing the collaboration of musicians who, at least on the surface, claim a Creole connection. Créolisation and the broader concept of Relation grew out of the particular politico-cultural situation of Martinique, as the opening of Glissant's Le Discours antillais (1997a) makes evident. As such, it does not necessarily map well onto the Guadeloupean experience. Here I partially concur with Richard Burton who believes this difference results from two factors: the strength of Guadeloupean nationalist ideology and the comparatively weak influence of Aimé Césaire on that island's cultural and political history (Burton, 1995: 149-50). While it is true that Césaire's personality does not loom over Guadeloupean politics as it does in Martinique, it is a mistake to ignore the influence of négritude on Guadeloupean nationalist thinking. In fact, the AGEG developed its political and cultural stance in response to Césaire and departmentalization. Its 1970 cultural report - a key document 
for the study of Guadeloupean cultural nationalism - acknowledges the importance of négritude as cultural resistance but criticizes Césaire and Senghor for conceiving anti-colonialism as a racial rather than a class struggle. Furthermore, the report denounces négritude for privileging racial solidarity within the African diaspora and failing to recognize the existence of essentially different national cultures in the Caribbean (Association générale des etudiants guadeloupéens, 1970: 33). Glissant in turn responded both to departmentalization and to the sort of nationalism espoused by pro-independence parties in Guadeloupe and Martinique by emphasizing the fluidity of culture and undermining pretences of racial or national essentialism. Yet, since the 1970s, the impact of nationalist ideology in Guadeloupe has been strong enough to limit the penetration of Glissant's ideas among Guadeloupean intellectuals.

Nevertheless, if I may borrow from anthropologist Clifford Geertz (1973), I do believe that even if the Tout-monde does not necessarily offer a model of global cultural exchanges, it does provide an attractive model for what these exchanges should be. Saying this acknowledges the utopian quality of some of Glissant's writings without denying his contribution to postcolonial theory. It is undeniable that Glissant brings a new perspective to the study of cultural interactions and power relations within the Caribbean and elsewhere, as Celia Britton (1999) demonstrates. Yet, the militancy of his recent publications, such Quand les murs tombent (Glissant and Chamoiseau, 2007; co-authored with Patrick Chamoiseau), reveals that the Tout-monde remains an unachieved dream - to paraphrase J. Michael Dash (Dash, 1995: 149). Glissant's oeuvre is best understood as participating in an ideological process, an ongoing debate about Antillean identity shaped by the French overseas departments' peculiar political status. ${ }^{17}$ Abstracting Glissant's poetics of Relation from its particular geopolitical context in order to extend it to disciplines beyond the field of postcolonial studies, as Martin did, is problematic. As the present chapter reveals, it is not only unsuited to explain collaborations such as Murray's Creole Project, but there is also a risk that it masks some of the inequalities that underlie them.

\section{Works Cited}

Association générale des etudiants guadeloupéens. 1970. Rapport culturel, 9ème congres. n.p.

Bébel-Gisler, Dany. 1989. Le Défi culturel guadeloupéen: devenir ce que nous sommes. Paris: Editions Caribéennes.

17 I borrow the concept of 'ideological process' from Katherine Verdery (1991). 
Bernabé, Jean, Patrick Chamoiseau and Raphaël Confiant. 1993. Éloge de la créolité / In Praise of Creoleness, édition bilingue. Paris: Gallimard.

Britton, Celia M. 1999. Édouard Glissant and Postcolonial Theory: Strategies of Language and Resistance. Charlottesville and London: University of Virginia Press.

Burton, Richard. 1995. 'The Idea of Difference in Contemporary French West Indian Thought: Négritude, Antillanité, Créolité'. In Richard D. E. Burton and Fred Reno (eds), French and West Indian: Martinique, Guadeloupe and French Guiana Today. London: Macmillan: 137-66.

Dahomay, Christian. 1997. Métòd Ka. Guadeloupe: n.p.

Dash, J. Michael. 1995. Édouard Glissant. Cambridge University Press.

Dudley, Shannon. 2008. Music from Behind the Bridge: Steelband Spirit and Politics in Trinidad and Tobago. New York: Oxford University Press.

Gabali, Joslen. 2003. Diadyéé. Les Abymes: Edition Créapub'.

Geertz, Clifford. 1973. The Interpretation of Cultures. New York: Basic Books, Inc. Gilroy, Paul. 1992. 'Cultural Studies and Ethnic Absolutism'. In Lawrence Grossberg, Cary Nelson and Paula A. Treichler (eds), Cultural Studies. New York: Routledge: 187-98.

Glissant, Édouard. 1989. 'Beyond Babel'. World Literature Today 63.4: 561-64.

—. 1990. Poétique de la relation. Poétique III. Paris: Gallimard.

-. 1993. Tout-monde. Paris: Gallimard.

—. 1996. Introduction à une poétique du divers. Paris: Gallimard.

—. 1997a. Le Discours antillais. Paris: Gallimard.

-. 1997b. Traité du tout-monde. Paris: Gallimard.

Glissant, Édouard, and Patrick Chamoiseau. 2007. Quand les murs tombent: l'identité nationale hors-la-loi? Paris: Galaadé, Institut du Tout-Monde.

Guilbault, Jocelyne, Gage Averill, Édouard Benoit and Gregory Rabess. 1993. Zouk: World Music in the West Indies. Chicago, IL: University of Chicago Press.

Khan, Aisha. 2007. 'Creolisation Moments'. In Charles Stewart (ed.), Creolization: History, Ethnography, Theory. Walnut Creek, CA: Left Coast Press: 237-53.

Kiavué, Klod. 2005. Interview by Luc Michaux-Vignes. 18 November 2005. Diks La Si Do. Médiathèque Bettino Lara: Basse-Terre.

Lafontaine, Marie-Céline. 1983. 'Le carnaval del'“Autre”. A propos d'“authenticité" en matière de musique guadeloupéenne: théories et réalités'. Les Temps Modernes 39.441-42: 2126-73.

-. 1988. 'Unité et diversité des musiques traditionnelles guadeloupéennes'. In Les Musiques guadeloupéennes dans le champs culturel Afro-Américain, au sein des musiques du monde. Paris: Éditions Caribéennes: 71-92.

Largey, Michael. 2006. Vodou Nation: Haitian Art Music and Cultural Nationalism. Chicago, IL: University of Chicago Press. 
Lockel, Gérard. 1978. 'Lolo Camphrin: un des derniers grands danseurs de gro-ka', Ja Ka Ta 3: 14.

—. 1981. Traité de gro ka modên: initiation à la musique guadeloupéenne. Baie Mahault: n.p.

Martin, Denis-Constant. 2008. 'Can Jazz be Rid of the Racial Imagination?: Creolization, Racial Discourses, and Semiology of Music'. Black Music Research Journal 28.2: 105-23.

Mintz, Sydney. 1996. 'Enduring Substances, Trying Theories: The Caribbean Region as Oikoumenê'. Journal of the Royal Anthropological Institute 2.2: 289-311.

-. 1998. 'The Localisation of Anthropological Practice: From Area Studies to Transnationalism'. Critique of Anthropology 18.2: 117-33.

Negrit, Frederic. 2004. Musique et immigration dans la société antillaise en France métropolitaine de 1960 à nos jours. Paris: L'Harmattan.

Palmié, Stephan. 2006. 'Creolization and its Discontent'. Annual Review of Anthropology 35: 433-56.

-. 2007. 'Is There a Model in the Muddle? Creolization in African-Americanist History and Anthropology'. In Charles Stewart (ed.), Creolization: History, Ethnography, Theory. Walnut Creek, CA: Left Coast Press: 178-200.

Rommen, Timothy. 2007. "Localize It": Rock, Cosmopolitanism, and the Nation in Trinidad'. Ethnomusicology 51.3: 371-401.

Schnepel, Ellen M. 2004. In Search of a National Identity: Creole and Politics in Guadeloupe. Hamburg: Helmut Buske.

Taylor, Timothy D. 1997. Global Pop: World Music, World Market. New York: Routledge.

Turino, Thomas. 2000. Nationalists, Cosmopolitans, and Popular Music in Zimbabwe. Chicago, IL: University of Chicago Press.

Verdery, Katherine. 1991. National Ideology under Communism: Identity and Cultural Politics in Ceauşescu's Romania. Berkeley: University of California Press.

\section{Discography}

Murray, David. 1998. Creole. Justin Time Records JUST 115-2.

Murray, David, and the Gwo-Ka Masters. 2002. Yonn-dé. Justin Time Records JUST 140-2.

-. 2004. Gwotet. Justin Time Records JUST 200-2.

-. 2009. The Devil Tried to Kill Me. Justin Time Records JUST 224-2.

Schwarz-Bart, Jacques. 2006. Soné Ka-la. Universal Music France B0009204-02. —. 2008. Abyss. Universal Music France 5308078. 



\section{Intertextualities:}

\section{Faulkner, Glissant, Condé}





\title{
Go Slow Now: Saying the Unsayable in Édouard Glissant's Reading of Faulkner
}

\author{
Michael Wiedorn
}

'Nous réclamons le droit à l'opacité' [We demand the right to opacity]:' this demand, articulated on the first pages of the Discours antillais [Caribbean Discourse] (Glissant, 1981: 11), resonates throughout Édouard Glissant's work. ${ }^{2}$ For Glissant, one way that literature can deploy opacity is to engage in a set of paired, paradoxical operations. It can say the unsayable, or make the invisible visible - or, more accurately put, present the absent. With his literary-critical text Faulkner, Mississippi, Glissant perceives both of these operations in the novels of an author whom he has hailed as the greatest of the twentieth century (Glissant, 1996: 54). This poetics of paradox is born of what Glissant sees as the shared cultural zone made up of the Caribbean and the US Gulf South region (cf. ibid.: 134, and passim). It is a poetics proper to this space; indeed, for Glissant, a literary method characterized by paradox and contradiction is necessitated by the particularity of this place or group of places.

In a rather contentious literary-historical formulation positing Faulkner

1 This and all subsequent quotations from this source and others were translated by the author of this chapter.

2 Many of Glissant's ideas concerning opacity are present in a nascent form in texts dating back as far as Soleil de la conscience (1956), and they are elaborated with regard to Faulkner's work, in particular in L'Intention poétique (1969) nearly thirty years before the publication of Faulkner, Mississippi (1996). This striking continuity casts doubt on portrayals of Glissant's thought as a long process of evolution, such as in Hallward, 1998. 
as the genitor of a multilingual, pan-Caribbean poetics, Glissant holds that Caribbean writers ranging from Wilson Harris to Carpentier to Glissant himself have borrowed the langage [language] of Faulkner's literary practice (Glissant, 2005b). ${ }^{3}$ While this literary practice is peculiar to the US Gulf South-Caribbean region, this shared, paradoxical poetics, which Glissant suggests is aligned with the very force of life itself (Glissant, 1996: 139-40), has the potential to extend outward into other spaces and places. Glissant thus implies, as with his repeated assertion that 'le monde entier s'archipélise et se créolise' [the entire world is becoming archipelago-ized and creolized] (Glissant, 2005a: 25), that the Caribbean, and by extension the shared US Gulf South-Caribbean cultural zone, can point the way towards new and more desirable forms of thought and, subsequently, life.

The opacity demanded by Glissant's texts serves as a sort of protective mechanism insulating the radical difference of the other from the self's at times depredatory search for knowledge. Opacity thus dictates that in the other an unknowable remainder persists. Glissant's figure of opacity, as I will show, also proves to be applied to his own ideas (including the idea of opacity itself). Glissant uses opacity and the set of paradoxes that accompany it as part of a larger enterprise of creation: that is, not only the creation of an ethical mode of being between self and other but also the impetus for creation of new literary forms. Through accommodating contradiction and allowing paradox to perdure, opacity points us towards possibilities for new forms of literary creation. The importance of such literary innovation to Glissant cannot be emphasized enough. For in his thought the causal link between new forms of writing and the creation of new forms of ethical life is spelled out quite clearly. The formula for bringing about this sequence of causally linked creations, however, is somewhat less so.

In Faulkner, Mississippi, composed during Glissant's stint at Louisiana State University in Baton Rouge, Louisiana, Glissant undertakes a survey of the entirety of Faulkner's oeuvre. He distills a reading that, as can be seen in

3 Here as elsewhere Glissant plays on the distinction in French between langage and langue, both of which are customarily rendered as 'language' in English. The two terms and the distinction between them have meant different things for different thinkers throughout history. For Glissant's purposes, 'langage' refers principally to the general code or sign system through which the subject frames his or her world. 'Langue', however, corresponds to the English word 'tongue', in terms of both the anatomical feature and the language spoken by a person (as in 'the English language'). This contrast allows Glissant to argue in 2005 that authors writing in the various languages (langues) of the Caribbean speak a common language (langage). 
Glissant's literary-critical work on other authors (cf., e.g., Glissant, 1969: 96), brings Faulkner's thought into line with his own. This effort runs counter to the author's views on race, or what many take to be his view (cf. Weinstein, 2009: 117-18). For in his chronicle of a journey through the past and present of the American deep South, which he situates in a history of profound and continuing race-based antagonism, Glissant reads Faulkner's work as laying, perhaps despite itself, the groundwork for an ethics of alterity.

What grounds Glissant's take on Faulkner's work is Glissant's slogan, 'Nous réclamons pour tous le droit à l'opacité' (Glissant, 1990: 209). ${ }^{5}$ As Patrick Crowley points out, this demand has gone beyond its earlier form in the Discours antillais. The right, or claim, to opacity has, almost ten years on in Poétique de la relation, left the colonizer-colonized opposition behind, extending the right of opacity to everyone (Crowley, 2006: 107). For Crowley, this shift proves that, pace Celia Britton, Glissant's main concern is less 'postcolonial resistance' than 'the capacity of poetic language to unsettle categorical systems of thought that are allied to power' (ibid.: 110). In Faulkner, Mississippi, I would like to submit, Glissant shows the potential of (his sense of) opacity to do both. In other words, Glissant uses opacity in Faulkner, Mississippi with both epistemological and political goals; indeed, his use of the term epitomizes the extent to which the political and epistemological dimensions are intertwined. And herein lies the entry point into Glissant's rehabilitation of Faulkner as an anti-racist, white Southern novelist: in Glissant's eyes, it is in Faulkner's epistemological opacity (his refusal or reluctance to make black subjects finally readable to his white characters and readers) that his political leanings (his fundamentally anti-racist poetics, his critical stance towards much of what his novels identify as Southern culture) can be discerned.

In work as in life, Glissant tells us, Faulkner was not interested in undertaking psychological studies (Glissant, 1996: 138). Glissant holds that Faulkner's concern, at least in his work, was what Glissant calls 'the abyss' (ibid.). Or rather, abysses, the abysses of non-knowledge and desperation that are brought about by 'le refus de la créolisation' [the refusal of creolization] and the refusal of the 'Other' (ibid.), cardinal sins in the Glissantian world view. Faulkner and his people (that is, Southern whites) struggle against the current that is the creolization of the world; they are 'offended' by 'Le mélange,

4 Mary Gallagher sketches some points of connection between Glissant and that other thinker of alterity, Emmanuel Levinas, in Gallagher, 1992.

5 Poétique de la relation [Poetics of Relation]. This cry's form has varied in Glissant's work: here the addition of 'pour tous' [for everyone] emphasizes its applicability to all people and places, and therefore its universality. 
le métissage, plus l'imprévu des résultantes' [Mixing, hybridization, plus the unpredicted nature of resultants] (ibid.: 117). As Glissant makes this point, he maintains the semantic slippage in his sense of the word 'creolization': the term denotes at once the creolization that Faulkner and his contemporaries would have considered to be 'racial mixing' as well as the more abstract and metaphysical creolization that would signify ever-increasing interconnection, combination and unpredictability (cf. ibid.).

As is his wont in other treatments of literary figures whom he admires, Glissant bends Faulkner's thought to meet with his own philosophy and poetics. Glissant's use of créolisation [creolization] as well as the imprévu [unpredicted] shifts the scene of conflict here from the ethnic to the epistemological realms. The 'refusal of creolization' of course refers to the rejection, on the part of whites who believe themselves to be of a 'pure' race, of other races and races that contain others within them (read: races that are perceived to be 'mixed'). But this refusal also refers to the rejection of a set of epistemological categories: again, 'Mixing, hybridization, plus the unpredicted nature of resultants'. While he is of course describing a refusal on the part of Faulkner of a certain race or of the mixing of what he perceives to be races, Glissant is also indicating that the 'sudistes' [sympathizers of the Confederates in the US Civil War] are refusing a certain way of knowing the world, one that would be grounded upon Glissant's idea of creolization.

For Glissant, Faulkner both is and is not a member of this group. Glissant perceives an ambivalence in Faulkner's literary texts, where 'La pose des nègres [...] est d'allure phénoménologique, c'est-à-dire qu'elle ne prétend à aucune profondeur, qui eût été imposture' [The way blacks are posed [...] appears to be phenomenological, which is to say that it doesn't seek any profundity, for that would have been fraud] (Glissant, 1996: 97). It is this methodological choice of phenomenology over ontology that allows Glissant to recuperate Faulkner as a thinker of the ethics of opacity: in Glissant's reading, Faulkner is concerned not with the truth of African-American subjects' being, but rather with how these subjects appear, or how they do not appear, as objects of knowledge.

In a curious foregrounding of the subjective, Glissant suggests that his reading is a matter of choice, or preference, explaining that 'je préfère penser qu'il y a dans ce choix méthodologique la lucidité et l'honnêteté (la générosité en somme, naturelle autant que systématique, c'est-à-dire d'ordre esthétique) de celui qui sait, qui admet en effet qu'il ne comprendra jamais ni les Noirs ni les Indiens' [I prefer to think that in this methodological choice there are the lucidity and the honesty (in sum, the generosity, both natural and systematic, which is to say aesthetic) of he who knows, who in effect admits that he will never understand either blacks or Indians] (ibid.; emphasis added). Glissant 
intensifies his speculation into Faulkner's psychology as he insists that Faulkner also knew that it would be, as Glissant puts it, 'odieux (et, à ses yeux, ridicule) de poser au narrateur tout-puissant et d'essayer de pénétrer ces consciences pour lui impénétrables' [odious (and, in his eyes, ridiculous) to posit an all-powerful narrator and to try to penetrate these consciousnesses which would have been for him impenetrable] (ibid.).

It is through this clarity of mind (lucidité [lucidity] - a curious way to praise Faulkner's understanding of the incomprehensible, the 'impenetrable', which is for Glissant the opaque) and in order to avoid the 'odious', that Faulkner has recourse to a language of his own invention (ibid.). Citing a critic who invokes Faulkner's 'langage de l'obscur' [Language of the obscure], Glissant holds that Faulkner 'remonte au plus obscur, au plus essentiel, là vraiment où pas un ne va. Il ne décrit pas, il ne fait pas de tableaux de genre' [goes back to the most obscure, the most essential, there where no one goes. He doesn't describe, he doesn't do genre painting] (ibid.: 216). It is thus in eschewing the search for the other's essence that Faulkner's literature sets in motion the essence of the encounter with the other. This apparent contradiction in terms - abandoning an essentialist framework in order to attain to 'the essential' - is made possible, once again, by Faulknerian language.

Noting that Faulkner's writing (in French translation) is fond of the phrasing 'en même temps' [at the same time], Glissant formulates a theory of the coexistence of opposites in Faulkner's work - a Faulknerian methodology that echoes Glissant's own. The language that makes Faulkner's writing possible does three things at once:

1. It describes.

2. And, in the process of description, it undertakes a paradoxical operation of saying the unsayable - 'cherche à dire cela qui est indicible dans la description et qui pourtant signifierait pleinement (fonderait en raison dévoilée) le décrit' (it seeks to say that which is unsayable in description and yet that which would fully signify (which would found in unveiled reason) that which is described] (Glissant, 1996: 190).

3. And, at the same time, it leads readers to understand that the underlying reason in the text can be unveiled but never attained - 'laisse sans répit à entendre que cette raison dévoilable est aussi bien inatteignable' [Ceaselessly makes it understood that this unveilable reason is also quite unattainable] (ibid.).

These three actions can be otherwise understood in terms of three objects, which Glissant sees at play in Faulkner's work. The first is the 'hidden truth' (ibid.), the shame or trauma that is the key to Faulkner's novels. This hidden 
truth generally takes the form of the impossibility of establishing a series of traceable lines of filiation - a term which, as we have seen, Glissant connects to root-identity, system thinking and the cruelty of Western empires (Glissant, 1990: 23-31, and passim). Second is description, which in Faulkner's work is necessarily 'visionary', in that 'elle est ainsi décidée par l'intuition, le pressentiment de la vérité primordiale' [It is thus decided by the intuition, the premonition of primordial truth] (Glissant, 1996: 190). Finally, there is the unstable reassurance offered by the text that this secret of a lacking origin will never be revealed (ibid.).

For Glissant, slavery becomes the unsayable, the unspeakable, in Faulkner's novels: 'Tout se fait comme si pour lui la tare de l'esclavage était une souffrance morale, disons de l'Être, une déchéance indélébile (l'absence à l'Histoire), beaucoup plus folle à porter que la souffrance physique de l'oppression et de la misère' [Everything happens as if for him the defect that was slavery was a moral suffering, one of Being, an indelible decline (the absence to History), one much more maddening to carry than the physical suffering of oppression and misery] (Glissant, 1996: 99). The lingering stain of slavery on the conscience of Faulkner's whites would thus influence so profoundly Faulkner's text that, as Glissant puts it, it is as if this mark were harder to bear than the more concrete pains of oppression and poverty.

This is no small point. Faulkner's emphasis on the suffering of whites, while it may seem provocative or even taboo, is connected to another unspeakable, which Glissant presents as the cipher of Faulkner's depiction of race relations: that is, lack of transparency, epistemological failure and the (white) subject's inability finally and thoroughly to know the other. Just as Faulkner cannot describe outright the shame, the stain that marks the consciousness of southern whites, he cannot speak the being of Southern blacks. Two 'primordial truths' thus are and are not spoken in Faulkner's work. The latter truth, Faulkner's inability fully or finally to know the being of Southern blacks, serves as the point of departure for Glissant's development of his ethics of opacity. Glissant holds that, through the figure of opacity, Faulkner seeks one thing: 'seulement et à toutes forces fonder en métaphysique l'obscur de la relation entre les Noirs et les Blancs' [Only, and altogether, to establish in metaphysics the obscure within the relationship between blacks and whites] (Glissant, 1996: 99). While the term opacity is a metaphysical one for Glissant, it also has a direct impact on the social relations that structure the polis. It is thus in literature that Glissant locates the possibility for a viable ethics. This ethics does not remain abstract, however, as Glissant links it to real, lived social interactions. The opacity that Glissant finds in Faulkner's novels is precisely what allows for the knowledge of, and participation in, the whole represented by the all-important Glissantian figure of the 
Tout-monde. ${ }^{6}$ Opacity makes possible the concept and lived experience of a community, while protecting the singularity of the individuals that form the community: 'C'est aussi cette même opacité qui anime toute communauté: ce qui nous assemblerait à jamais, nous singularisant pour toujours. Le consentement général aux opacités particulières est le plus simple équivalent de la non-barbarie' [It is also this very same opacity that animates every community: that which forever brings us together, while singularizing us forever. The general consent to particular opacities is the simplest equivalent of non-barbarism] (Glissant, 1990: 209). Acknowledging, and living in terms of, the opacity of the other is the most basic way of conceiving of a society that would oppose itself to the barbarism of the past.

Herein lies one of the fundamental links between Glissant's abstract conception of the 'poetics of Relation' and the effects of this idea upon political actuality. The other resists the self's effort to know him/her in two ways: in terms of density and in terms of change. The other is thus never ultimately knowable because the entirety of his/her being never becomes apparent or readable to the self. Even if it were to become thus, its nature of constant flux would preclude any mastery characterizing the knowledge of the other. As Glissant explains, 'Car la poétique de la relation suppose qu'à chacun soit proposée la densité (l'opacité) de l'autre. Plus l'autre résiste dans son épaisseur ou sa fluidité (sans s'y limiter), plus sa réalité devient expressive, et plus la relation féconde' [For the poetics of relation postulates that the density (the opacity) of the other is offered to each of us. The more the other resists in his/her thickness or fluidity (without being limited to either), the more his/her reality becomes expressive, and the more the relation fecundates] (Glissant, 1969: 23).

Otherwise put, for Glissant as for Faulkner, literature is the place where a certain, seemingly paradoxical phenomenon of perception occurs. This phenomenon is the coincidence of opposites, in this case in the form of a revelation of non-revelation: that is, the final revelation of the other as concealed and unknowable finally. This paradox is decisive in the elaboration of Faulkner's literary project. The différance of Faulkner's writing, for Glissant, lies in the fact that it stages difference in a continued pattern of deferral. For example, Glissant illustrates that the différé [differed/deferred] of Faulkner's

6 This figure, which has proved contagiously compelling to many of Glissant's readers, represents, in very broad strokes, Glissant's metaphysical sense of an oneness and interconnection underlying all worldly phenomena and beings. For a more elaborate treatment of the term, see Glissant's Traité du tout-monde (1997) (which, despite its title, is far from a treatise) or the novel Tout-monde (1993) that accompanies it. 
writing goes back, without ever finally arriving, to a presupposition: that of 'l'établissement impossible, la légitimité déniée du Sud' [The impossible establishment, the denied legitimacy of the South] (Glissant, 1996: 191). Given this impulse in Faulkner's work, it becomes clear that, as Glissant puts it, 'Le travail de l'écrivain est de révéler ce présupposé, tout en exposant ses équivalences douloureuses dans le présent, tout en signifiant que cette révélation est à jamais reportée' [The task of the writer is to reveal this presupposition, all the while exposing its painful equivalences in the present, all the while signifying that this revelation is forever deferred] (ibid.).

Faulkner would thus realize the impossible in literature. In his novels the (black) other is made visible in his/her final invisibility to the (white) self; the other's final absence to the self is unveiled. By the same token, the impossible knowledge that haunts the South is articulated without being spoken. More importantly, Glissant reads Faulkner as seeking political change though a literary language that undertakes the impossible. This newly invented form of writing may lead, Glissant suggests, to new political inventions. The Southern writer therefore seeks to 'dire l'impossible du Sud sans avoir à le dire, d'en donner une écriture qui remonte patiemment à tout l'inexprimé de cet impossible, et s'il se trouve d'y changer quelque chose par la seule force de cette aventure' [say the impossible of the South without ever having to say it, to set forth a writing of it that would go back to all that is unexpressed in this impossible, and perhaps to change something by the very force of this adventure] (Glissant, 1996: 207-08). In his lifetime, Glissant adds, Faulkner did all but the last.

Glissant's politicized reading of opacity in Faulkner's texts thus finds itself in conflict with the author's own political actions. Indeed, Glissant's enthusiasm for a white, Southern writer whose racial politics were well known proved troubling to the students of Southern University, to whom Faulkner, Mississippi is dedicated. Given Faulkner's famous remarks that African Americans should 'go slow now' (Glissant, 1996: 145) rather than seek rapid and revolutionary change, and given that, as Glissant puts it, African Americans in Faulkner's oeuvre are 'dépositaires de la souffrance, gardiens du temple de l'indicible' [depositories of suffering, guardians of the temple of the unsayable] who are never allowed the possibility to rise up (ibid.: 132), the students of this historically black university in the deep south proved loath to follow Glissant's example in reappropriating Faulkner. Glissant allows that these students taught him that 'aucune qualité de littérature ne vaut le prix de la chosification même emblématique d'une communauté' [no quality in a literature is worth the price of the thingification, even emblematic, of a community], but responds that Faulkner's readers are 'libres de regarder Faulkner dans les yeux, d'aller avec lui où 
nous voulons aller' [free to look Faulkner in the eyes, to go with him where we'd like to go] (ibid.: 146).

In this retort, what Glissant holds to be the true value of Faulkner's work becomes evident. For Glissant, the effects of Faulkner's work are profoundly radical. For in the Faulknerian corpus careful readers can make out what Glissant calls 'un bouleversement des conceptions unitaires de l'être, une mise en différé de l'absolu identitaire, un vertige de la parole' [an overturning of the unitary conceptions of being, a differing/deferring of the identitarian absolute, a vertigo of speech] (ibid.: 146-47). These latter qualities constitute, for Glissant, the 'revenge' of the Faulknerian corpus against the 'génial puritain qui l'a engendrée' [the brilliant puritan who engendered it] (ibid.: 147). Glissant here presents himself as a partisan not of the author but of the author's corpus and, more specifically, of its effects. It is worth recalling Glissant's argument that Faulkner's method has influenced not only his own work but also that of many Caribbean writers, from Carpentier to Wilson Harris. Indeed, Glissant holds not only that these writers are 'influenced' by Faulkner, but that, much more provocatively, the 'techniques of writing' in the common langage of Caribbean writers in French, Spanish and English, were borrowed from Faulkner:

Un Alejo Carpentier (Cuba), qui écrit en espagnol, un Wilson Harris (Guyana), qui, lui, écrit en anglais, un Aimé Césaire (Martinique) ou moi-même, qui écrivons en français, avons un langage commun qui est fait de confiance dans les mots, dans le pouvoir du verbe, dans les techniques d'écriture que nous avons empruntées essentiellement à Faulkner: accumulation, listage, redondances, entassements, révélations différées. Tout cela constitue un langage, une manière de s'approprier les langues que nous avons tous en commun. Cela constitue une donnée littéraire spécifique, une esthétique de la relation, si vous voulez! (Glissant, 2005b)

Glissant would thus have his readers believe that he suffers from very little 'anxiety of influence' (Bloom, 1973). In this instance of self-representation, Glissant's relationship to Faulkner, like his access to Faulkner's psychology,

7 'An Alejo Carpentier (Cuba), who writes in Spanish, a Wilson Harris (Guyana), who writes in English, an Aimé Césaire (Martinique) or myself, who write in French, we have a common language [langage] that comes from confidence in words, in the power of the word, in the techniques of writing that we essentially borrowed from Faulkner: accumulation, listing, verbosities, hodgepodges, differed/deferred revelations. All that constitutes a language [langage], a way of appropriating languages [langues] that we all have in common. That constitutes a specific literary given, and aesthetics of relation, if you like!' 
would appear to be transparent. For Glissant, Caribbean writers, or at least this diverse group of well-known Caribbean writers, are all heirs of the white, racist, sudiste Faulkner. ${ }^{8}$ This kinship, which would transcend perceived racial/ethnic differences without negating them finally, is made possible by a shared relationship to language and to literary technique.

Yet just as Faulkner, Mississippi maintains that there is a direct and traceable lineage connecting Faulkner and a host of Caribbean writers, Glissant holds that the Faulknerian literary corpus also marks a radical rupture with the Western literary tradition. Faulkner's writing is also the scene of a creative destruction of foundational genres in Western literature: not only the novel, but also the epic and tragedy. This death and rebirth of fundamental modes of literature will, in Glissant's view, contribute to bringing about a more ethical tomorrow. Seizing upon two interrelated definitions of the epic and tragic modes, Glissant argues that both come to know their decadence in Faulkner's writing. Faulkner's entire oeuvre becomes a 'méditation sur l'impossibilité de l'épique, en ce temps et en ce lieu-ci. Ou plutôt un forcènement contre cet impossible, un effort héroïque pour le faire naître et l'exprimer à partir de l'improbable qu'il suppose' [meditation on the impossibility of the epic, in this time and in this place. Or rather a fury raging against this impossible, a heroic effort to bring about its birth and to express it, taking as a point of departure the improbable that it postulates] (Glissant, 1996: 169). The tragic mode, just as swiftly defined, figures prominently in the Faulknerian corpus as well, a corpus that stages repeatedly this literary mode's downfall.

La légitimité, le drame de son épuisement et la course de sa restauration constituent le principe premier du théâtre tragique traditionnel. Parce que la légitimité, dans les cultures occidentales, conduit le fil de l'être, le chemin obscur qui rattache toute communauté à une Genèse, l'établissant ainsi dans son droit souverain. ${ }^{9}$ (Glissant, 1996: 177)

The 'grandeur' and the nouveauté [novelty] in Faulkner, for Glissant, stem from the fact that both the epic and the tragic modes of literary production see their own downfall, or, as he puts it, 'butent sur leurs propres impossibles'

8 Glissant's emphasis on Faulkner could, I would submit, be seen as vulnerable to J. Michael Dash's critique of the all-too-common assignation of what amounts to a single origin to Francophone Caribbean writing. See, for example, Dash's discussion of the Surrealist contact (Dash, 2006).

9 'Legitimacy, the drama of its exhaustion and the course of its restoration constitute the first principle of traditional tragic theatre. Because legitimacy, in Western cultures, runs along the thread of being, the obscure path that attaches every community to a Genesis, thus establishing it in its sovereign right.' 
[come up against their own impossibles] in Faulkner's work (Glissant, 1996: 180).

For Glissant, salvation lies in the advent of a new epic form. Faulkner's work, in Glissant's view, intimates to us the possibility of a new sort of epic, one that would dispense with any effort to make whole what is fragmented, to seek resolution in the dissolute; one that would be, as Glissant puts it,

Une ouverture insoupçonnable, imprévisible, qui ne serait en rien système. Qui serait fragile, ambiguë, éphémère, mais brillerait de tous les éclats contradictoires du monde. Il faut qu'il en soit ainsi, sinon le tarissement de l'épique traditionnel aurait produit une mort plus froide et plus dure encore que la mort même. ${ }^{10}$ (Glissant, 1996: 139-40)

How is it that, in Glissant's thought, writing comes to serve as a conduit from individual subjects to the world-as-whole, and from the world as it is in the present to future Utopias? From a single, fixed origin set in the past to an origin become multiple and set in motion ('l'en-aller'), ${ }^{11}$ from a myth that founds the legitimacy (or the 'being' in Glissant's parlance) of an ethnic or racial group to the literary project of deploying a new imagination: this is the shift from the moribund epic form to the epic-as-Relation. And, for Glissant, herein lies one of the ways in which Faulkner can be valued - as a writer who began to measure the changes that need to be made in the world and in the imaginations of his readership. For Glissant, Faulkner 'mesure ce qu'il faudra de renversements dans les sensibilités' [measures what kind of overturnings will be necessary in our sensibilities] (Glissant, 1996: 134). Crucially, political change is, in this view, prefaced by the work of literature: 'Ce renversement, l'œuvre de Faulkner y travaille, non par leçon de morale, mais par changer nos poétiques' [this overturning, Faulkner's oeuvre works towards it, not through moral lessons, but rather by changing our poetics] (Glissant, 1996: 134).

It is this impetus towards change in the imagination, towards change in poetics, that allows Glissant to recuperate Faulkner an ancestor of sorts. For Cilas Kemedjio, 'The quest for founder-ancestors ... is part of that canonizing tendency that torments writers and critics of Antillean literature' (Kemedjio,

\footnotetext{
10 'An opening beyond suspicion, unpredictable, one that would in no way be a system. That would be fragile, ambiguous, ephemeral, but that would shine with all the contradictory radiance [éclats] of the world. It must be so, for otherwise the extinction of the traditional epic will have produced a death colder and harder than death itself.'

11 This Glissantian neologism might be translated as 'the in-the-process-ofgoing', or 'the in-motion'.
} 
2002: 229). It would seem, then, that Glissant has found in Faulkner a 'founder-ancestor' who allows him to critique the ideas of founding and of ancestry. Whether fuelled by 'torment' or not, Glissant's choice of Faulkner is significant in that it is not based on racial or ethnic confraternity, but rather on a shared poetics and a common spirit of critique: it is for this reason that Glissant's reading of Faulkner is relatively untroubled by the latter author's race or his overt implication in the politics of race of his time. For Glissant, imagination would thus transcend racial or socioeconomic belonging. ${ }^{12}$

For Glissant, the writer's role in the advent of the Tout-monde is to model new forms of thought and to breathe literary life into them. As is often the case in Glissant's work, progression towards a higher, future goal (e.g., the Tout-monde) does not imply a unilateral and conclusive departure. Rather, a relationship of simultaneous détour/retour [detour/return] is instated between the particular and the universal: in the case of Faulkner, for example, Glissant reads the writer as attaining to the 'plus essentiel' [most essential] (Glissant, 1996: 216) of human interaction precisely through his exploration of opacity and through deepening his study of Yoknapatawpha county, a very particular, very small place. Faulkner is 'the greatest writer of the twentieth century' for Glissant, in that he was 'celui qui avait le plus à révéler de son propre lieu incontournable en même temps que de la Relation de ce lieu à la totalité-monde' [he who had the most to reveal of his own incontrovertible [incontournable] place, at the same time as of the Relation of that place to the totality-world] (Glissant, 1996: 54). Herein lies the conduit between the particularity of Faulkner's novels and the universality (although Glissant would spurn the term) of the methodological experimentations that guide them. Through the decadence and rebirth of established literary forms that is staged in his work, Glissant's Faulkner becomes a deeply revolutionary ontological thinker:

Ces ouvertures infinies de l'épique et du tragique (leur échec en fin de compte, mais qui les renouvelle si complètement), et cet effort, le plus total que, depuis Nietzsche, un créateur ait entrepris pour 'repenser' cela (l'Être, et par dérivée dans le réel: l'identité, l'appartenance) sur quoi reposait depuis tant de siècles et avec tant de profondeur l'ontologie occidentale. ${ }^{13}$ (Glissant, 1996: 181-82)

12 Glissant writes that 'The same skin can clothe different imaginaries [imaginaires] ... Madam Condoleezza Rice draws on the same imaginary as $\mathrm{Mr}$ George W. Bush, and has nothing to do with Mr Mandela or with Martin Luther King' (Glissant and Chamoiseau, 2007).

${ }_{13}$ 'These infinite openings of the epic and the tragic (their failure, finally, but 
It is also through this project of rethinking Being, identity and belonging that Faulkner can be seen as one of Glissant's forerunners (and Glissant might have included Deleuze in this Nietzschean line or lineage as well). The terms Glissant uses to describe Faulkner's literary practice, terms such as 'repenser' [rethinking] (Glissant, 1996: 181-82), 'renouvellement' [renewal] (ibid.: 141), 'renversement' [overturning] (ibid.: 134) could be fruitfully applied to the Martinican author's own literary-philosophical project. Indeed, in response to Stathis Gourgouris's 2003 inquiry into the philosophical potential of literature entitled Does Literature Think?, one might propose a Glissantian reformulation of Gourgouris's question: Does literature re-think? If we are to take Glissant at his word and follow him in his rereading of Faulkner, a corollary question arises: How can a connection be drawn between thought and life, between a Faulknerian rethinking of ethical relations and concrete, political changes in actuality?

It can be said that Faulkner, Mississippi is a text on how to read opacity, on how to read opaquely, and on how to proffer an opaque reading. The 're-' prefix, moreover, reveals Glissant's overall preoccupation with literature as a creative and creating activity whose effects extend beyond the book. As to the question of what might inhabit this beyond, and as for the political potentialities of 'new' Faulknerian literary forms, for the moment the idea of creolization dictates that there is only one prediction we can be sure of with regard to future creation, literary or otherwise: that it will be imbued with the unpredictable.

\section{Works Cited}

Bloom, Harold. 1973. The Anxiety of Influence: A Theory of Poetry. New York: Oxford University Press.

Britton, Celia M. 1999. Edouard Glissant and Postcolonial Theory: Strategies of Language and Resistance. Charlottesville and London: University of Virginia Press.

Crowley, Patrick. 2006. 'Édouard Glissant: Resistance and Opacité. Romance Studies 24.2: 105-15.

Dash, J. Michael. 2006. 'Caraïbe Fantôme: The Play of Difference in the Francophone Caribbean'. Yale French Studies 103: 93-105.

Gallagher, Mary. 1992. 'La Poétique de la diversité dans les essais d'Édouard

one that renews them so completely), and this effort, the most total that, since Nietzsche, a creator has undertaken in order to "rethink" that (Being, and by extension in the real: identity, belonging) upon which Western ontology has rested for so many centuries and with such profundity.' 
Glissant'. In Yves-Alain Favre and Antonio Ferreira de Britto (eds), Horizons d'Édouard Glissant: actes du colloque international de Porto, 24-27 octobre 1990. Pau: J. \& D. Éditions, 1992: 27-35.

Glissant, Édouard. 1956. Soleil de la conscience. Paris: Éditions du Seuil.

—. 1969. L'Intention poétique. Poétique II. Paris: Éditions du Seuil.

—. 1981. Le Discours antillais. Paris: Éditions du Seuil

—. 1990. Poétique de la relation. Poétique III. Paris: Gallimard.

-. 1993. Tout-monde. Paris: Gallimard.

-. 1996. Faulkner, Mississippi. Paris: Stock.

-. 1997. Le Traité du tout-monde. Poétique IV. Paris: Gallimard.

-. 2005a. La Cohée du Lamentin. Poétique V. Paris: Gallimard.

—. 2005b 'La "créolisation" culturelle du monde, entretien avec Édouard Glissant'. By Tirthankar Chanda. France Diplomatie. 27 October 2005.

Glissant, Édouard, and Patrick Chamoiseau. 2007. 'Les Murs, par Patrick Chamoiseau et Édouard Glissant'. 4 September 2007. <http://cabaret.voltaire. over-blog.com/article-les-murs-par-patrick-chamoiseau-et-edouard-glissanta-propos-de-l-identite-nationale-38387940.html>. Consulted 11 December 2011.

Gourgouris, Stathis. 2003. Does Literature Think?: Literature as Theory for an Antimythical Era. Palo Alto, CA: Stanford University Press.

Hallward, Peter. 1998. 'Édouard Glissant between the Singular and the Specific'. Yale Journal of Criticism 11.2: 441-64.

Kemedjio, Cilas. 2002. 'Founding-Ancestors and Intertextuality in Francophone Caribbean Literature and Criticism'. Research in African Literatures 33.2: 210-29.

Weinstein, Philip M. 2009. Becoming Faulkner: The Art and Life of William Faulkner. New York: Oxford University Press. 


\title{
Édouard Glissant and the Test of Faulkner's Modernism
}

\author{
Hugues Azéradt ${ }^{1}$
}

Only for the sake of the hopeless ones have we been given hope.

Walter Benjamin, Selected Writings,

Vol. 1, 1913-1926 (1996), pp. 335-56

Et qu'on devrait, qu'on pourrait, à nouveau mais totalement, commencer - d'une autre sorte d'humanité

Édouard Glissant, Faulkner, Mississippi (1996), p. 299

[And that we should, we could, begin again - completely, totally - a new type of humanity (Glissant, 2000: 218) $]^{2}$

Les paysages faulknériens s'altèrent d'une mauve fragrance, d'une puissance de mélancolie qui font que vous avez envie [...] d'en revenir à peindre votre propre paysage, proche ou lointain.

Édouard Glissant, Faulkner, Mississippi (1996), p. 148

1 I would like to thank Marion Schmid for the many improvements she has made to this chapter. Thank you also to Celia Britton, Teresa Bridgeman, Michael Wiedorn, J. Michael Dash, Jean-Pascal Pouzet, Bernadette Cailler and Jean-Luc Tamby, all of whom have enriched my approach to Glissant and Faulkner through fruitful exchanges.

2 Where a published translation of Glissant's work exists, this is cited, with references. Where no references are provided, no published translation is available and the translation is the work of the translator of this chapter. 
[Faulkner's landscapes are suffused with a fragrance of mauve, with a power of melancholy that makes you feel like painting your own countryside, whether near or far (Glissant, 2000: 106)]

In Faulkner, Mississippi, Glissant provides us with an innovative reading of an author whose work we thought we already knew almost inside out. Indeed, in 1996, compared with other great modernists such as Joyce, Woolf, Proust, Kafka and Musil, Faulkner was beginning to seem outdated, 'unsaleable' and even undesirable within the field of literary criticism. Faulkner's heyday was under New Criticism and at the time of the White House's anti-communist policies of the 1950s and 1960s (Schwartz, 1988), and only a small number of brilliant hardliners such as Philip Weinstein, Barbara Ladd, John Mathews, Richard Godden, André Bleikasten and Claude Romano, along with a few others, have continued to explore his work and open it up to the new critical trends of the 1990s (see in particular Mathews, 2004; Ladd, 2003; 2007; Loichot, 2003; Romano, 2005; Bleikasten, 2007; Weinstein, 1996; 2006; Chrétien, 2009). Despite these endeavours, Faulkner has not survived the theoretical turns of these last decades well. It would be too easy to explain this by pointing to the latent and atavistic racism of this 'white Southerner', along with the complexity and apparent decline of his style (the difficulty of the books which preceded Go Down Moses (1942) was considered to be an indisputable mark of quality by pro-modernist formalists, whereas the ratiocinations of his final novels betrayed, in their view, a delirious and paternalistic humanism).

This, then, was the apparent state of affairs when Glissant's book stirred up the Parisian critical world in 1996, and very shortly afterwards did the same in Faulkner studies, partly as a result of the English translation. After Malraux, Camus, Sartre and almost all the literary figures of the post-war period, from Marguerite Duras to Claude Simon, here was another writer-thinker in the French language who had come to tell the world that Faulkner is an author who really cannot be ignored, albeit, this time, for an unexpected reason: Faulkner, Glissant tells us, is a writer, indeed almost the only writer, who anticipated the tout-monde: 'oui, Faulker est un moment de la pensée-monde' (Glissant, 1996: 143) [Yes, Faulkner is a moment, a beat in the world-thought (Glissant, 2000: 102)]. A beat which demands that we move beyond it, as Glissant's novels Tout-monde (1993) and Sartorius (1999) imply through their themes, their geographical fragmentation and the words of the 'déparleur-poète-narrateur' [lunatic-poet-narrator] of Tout-monde, if we can believe him: ${ }^{3}$

3 This moment of distancing (going further than Faulkner in its (re)vision of 
Ce romancier, dont on pouvait dire qu'il partait aussi en poésie, essayait de tracer, de révéler les personnes par le paysage (nous ne croyons plus avec lui au personnage de roman qui vous en impose, ni aux astuces de l'auteur: les descriptions rusées qui tâchent de présenter un quidam sans en brosser vraiment le portrait, du genre 'non pas seulement, mais' plutôt que 'assuré pas peut-être', les dialogues sous-entendus qui dévoilent peu à peu et laissent tant à deviner [...]). ${ }^{4}$ (Glissant, 1993: 521)

Whereas Le Discours antillais (1981a) still followed the patterns of traditional literary discourse, setting tale and myth in opposition, Faulkner, Mississippi plunges into Faulkner's work, setting out to explore its physiognomy by analysing it as a whole. Most important, though, as will be argued here, it also establishes an extreme relationship intended to test out Glissant's own work and concept of literature against those of a writer who moved him deeply, before putting these to the test in their turn. This relationship should allow us a clearer vision of Glissant's aesthetic project, a project which strategically pursues Faulkner's modernism and in doing so diverts it and redeems it.

character, which, like the narrative voice, is now truly scattered to the winds, disappearing into a landscape which has become the only true vehicle for narration) would in its turn disappear in an intriguing swing of the pendulum (between mimeticism and detachment). A close examination of the form and structure of Ormerod (Glissant, 2003) reveals that it follows the formal and typographical structures of Faulkner's greatest books: long sentences, almost without punctuation, their rhythms governed by simple indents, for example in the section entitled 'Les Gros Mornes' (Glissant 2003: 220-44), which itself immediately calls to mind 'The Bear' in Go Down Moses and 'The Courthouse' in Requiem for a Nun; juxtapositions of different time frames; italics which signal shifts to embedded levels of consciousness and temporal frames (Romano, 2005: 7). And while Tout-monde might at first glance appear to be Glissant's attempt to write the epic of a world diametrically opposed to Faulkner's universe, we only have to remind ourselves of that other unique attempt to write on a universal scale, Faulkner's great diasporic work, A Fable (1954), in which a Creole character, prophet of a humanity yet to come, is given the name Tooleyman (tout-le-monde [everyone/all the world]).

4 'This novelist, who could also be said to have glided off into poetry, attempted to trace out and reveal his characters through landscape (with him we lose our belief in those characters in the novel who thrust themselves upon us and in the author's artifices: in trick descriptions which attempt to present some character without really filling in the details of his portrait, along the lines of "not-just-but" rather than "certain-not-perhaps", in implied dialogues which produce gradual revelations and leave so much to the imagination [...]).' See also Glissant, 1993: 193 on the question of 'non pas seulement mais' [not-just-but]. 
Tracing the circular pattern which is part of his signature, Glissant's critical reading of Faulkner cannot be separated from the way in which he, in his turn, invites us to read his own work.

It is by allowing the South, and the mythical county of Yoknapatawahpa, to establish itself in its true geographical location, the creolizing archipelago which stretches from South America to the shores of Louisiana, that Glissant contrives to take a writer's work which had become mired in an increasingly individualizing and atavistic space and whose flagging universalism was denigrated by critics, and free it from its ghetto. Barbara Ladd, in the footsteps of J. Michael Dash, has given a clear account of this geographical, ideological and aesthetic repositioning which transforms Faulkner into a writer of 'the other America' (Dash 1998). ${ }^{5}$ She picks up on a feature of Faulkner's work remarked on by Glissant as early as L'Intention poétique (Glissant, 1969) and later in Le Discours antillais (1981a), namely his view of history as non-linear and circular, as passion and as trace, overturning the spatio-temporal logic which governs Western history. She accordingly suggests that

our habit of seeing the presence of History in Faulkner's texts as an irresistible force and Faulkner himself chiefly as a Euro-American writer in the midst of exploring the South's obsolescence has blinded us to his Créolité, to his own roots in a Creole context, to his Creole suspicion of and resistance to the Historical narrative. (Ladd, 2004: 33-35)

Nevertheless, Glissant is careful not to clarify Faulkner's opacity, absorbing it into his approach and reflecting on his own work which appears to offer him an analogous historical aporia that nevertheless differs in essence from that of Faulkner: the abyss of the origins of the South, produced by an original lack, a linearity ruptured by defeat and a false legitimacy based on slavery, is in fact one of the concomitant causes of that other historical abyss, of the 'non-histoire' [non-history] (Glissant, 1981a: 130-31) that marks the islands of the Caribbean. But there is a mutual interaction between these two abysses for Glissant, who probes the historical abyss at the heart of the South and produces his own paradox from it: the universe of the South shares a crisis of filiation, a parental and historical trauma, with the world of the Caribbean islands. Absalom, Absalom! (Faulkner, 1936) in particular is a symptom of this historical trauma, being the book of the impossible 'désiré historique' [desire for history] (Glissant, 1981a: 260). Glissant, adopting the de-essentializing approach to be found in all his thought and work, views Absalom! as the great

5 See also the section 'rêve d'une autre Amérique' [dream of another America] in Tout-monde (Glissant, 1993: 515-22). 
book of questions, whose techniques of modernist writing are in fact part of an essay in delayed and tragic revelation - 'un enroulement d'un vertige [...] autour d'un lieu qu'il lui faut signifier' (Glissant, 1996: 20) [a whirling vertigo [...] centered in a place to which he felt a need to give meaning (2000: 8)] which calls back into question the foundations not only of the false epic of Southern literature but also of all atavistic cultures: legitimacy and legitimization are simply misreadings offered in response to the desires of nations to define themselves by excluding others. Faulkner provides no answer, but he asks the right question. Absalom! does not reduce the abyss and the Other to a transparent vision: it brings out a basic antagonism and confirms the death of the traditional epic (Glissant, 2008: 75, 89). Glissant replaces the false epic with the possibility of a new poetics, a new form of epic, open to and founded on his concept of Relation. ${ }^{6}$

Like Proust in Contre Sainte-Beuve and the pastiches of the masters which are strategically worked into the Recherche, Glissant transforms his work of criticism into a vertiginous mirror of his own work: he modifies our approach to Faulkner by taking us right back towards the origins of the most inextricable and inexpressible aspects of Yoknapatawpha, but he also sets us on the path towards a critical approach to his own work. We should read his Faulkner, Mississippi as a mirror structure in which the work of each author would be tested out by that of the other, that is, put into Relation. What is effectively a sort of literary manifesto-criticism also contains its own antidote: as Glissant and Faulkner's voices intertwine almost to the point of confusion, markers of distance and warnings emerge here and there, sometimes through the distancing technique of self-criticism (avoiding the creation of 'Faux Faulkner' (Glissant, 1996: 44) or the inane imitation of techniques which are all the more alluring for being inseparable from their

6 There is a connection to be made between Glissant's redefinition (not confusion) of genres (lyric, epic and dramatic) and the work of Emil Staiger in Basic Concepts of Poetics (Staiger, 1991). The latter has been very influential in France and rethinks genres 'not as essences but as versions of ongoing processes of foundational human experience and thus as versions of concrete historical existence' (ibid.: 30). Staiger accordingly associates the epic genre 'with its disclosure of the moment-of-vision, or bringing the phenomenal world into unconcealment, a disclosure that is primarily present-oriented', while the lyric genre is associated with the past and drama with the future (ibid.: 33). For Glissant, the epic is not an a priori and immutable form, but is more fundamentally a means to reveal a coming-into-awareness, a movement towards consciousness, to which can be added the other preponderant temporalities constituted by the lyric (the past, the having-been) and drama (the future, the being-who-becomes). 
intent, for example the use of modals, of 'non seulement, mais' ([not only, but], etc.), sometimes through the intrusion of voices from his other books, enjoining him not to project himself onto the Other; in particular the voice of Mycéa, who repeatedly intervenes in the midst of his reflections:

Elle me déclare tout bonnement, au moment d'un tel raisonnement que j'ai comme déparlé à voix haute, que oh! non elle ne veut pas paraître dans ce livre que je fais là [...] Je lui dis qu'un pronom a de la force quand on ne sait pas qui se cache derrière. Que d'autres supputeront qu'elle' c'est Mycéa 'celle dont le poète est enchanté'. Que d'autres calculeront, si ça les intéresse, une identité imaginaire, peut-être une synthèse des quelques éléments dont ils disposeront. Elle me dit de ne pas indéfinir comme ça, sans raison, et de ne pas faire mon Faulkner avec ce pronom, qui après tout est le sien.7 (Glissant, 1996: 243)

This internal echo is part of a Glissantian aesthetic which constantly plays games with itself and, in the process of theorizing, is careful to reject its own identity, to deny itself transparency: Mycéa's witticism about the 'misappropriation' and the 'reasoning' of the critic-narrator is a direct reference to the temptation to conceptualize and 'reason' which plagues Glissant's fictional and often antithetical twin, the great calculator, Mathieu Béluse, who can be compared on occasion to Quentin Compson in Absalom! or even to Joyce's Stephen Dedalus or Proust's 'Marcel'. It is Mathieu who reluctantly falls under the spell of reason and challenges Papa Longoué in Le Quatrième Siècle, 'ne sachant pas encore que Mathieu l'avait vaincu, puisque le jeune homme le forçait à suivre le chemin le plus logique, et que voici qu'il raisonnait en que, en donc, en après et avant' (Glissant, 1964: 47) [Not yet knowing that Mathieu had won because the young man was forcing him to follow the 'most logical' path, and here he was arguing that and therefore and after and before' (Glissant, 2001: 40)].

Faulkner, Mississippi both tests out and embodies the poetics of Relation, which remains the defining mode of Glissant's practice: it is an exercise in self-experimentation in which he reveals to us the essential characteristic

7 'She tells me frankly as I was thinking out loud that I am speaking nonsense. Oh! No, she says - she does not want to appear in this book I am writing. [... ] I tell her that a pronoun has power even when you do not know who is behind it. Some argue that "she" is Mycea, "the one with whom the poet is enchanted". Others deduce an imaginary identity, if this interests them, perhaps a synthesis of several elements at their command. [...] She tells me not to work like that, needlessly, and not to construct my Faulkner out of this pronoun which, after all, is hers' (Glissant, 2000: 176-77). 
of his work which he has long described as his poetics (in five books over forty years), which he has more lately called his aesthetics in Une nouvelle région du monde (Glissant, 2006) and which, most recently, he has described as 'poésie en étendue' [poetry across space] in the defining subtitle of Philosophie de la relation (Glissant, 2009). ${ }^{8}$ Glissant exercises his right to preserve his opacity, just as he makes no attempt to shed light on that of Faulkner, instead testing out his poetics of Relation as a new form of criticism and thought. Just as he redefines the concept of literary tradition, as he redefined the relationships between literature and history, between myth and folktale, between language and language-use, between atavistic and composite cultures - on each occasion producing a diversion (rather than an apparent inversion) of terms - he here redefines the way in which we speak of and theorize literary works, including his own. ${ }^{9} \mathrm{He}$ completely overturns the concept of anxiety of influence since, in his reformulation, influence is merely an incomplete early hypothesis, a false understanding of a much more potentially productive phenomenon, that of the poetics of Relation: the concept of influence is a stunted, linear and hierarchizing way of viewing a literary history which turns out to be far more complex than

8 Since the time of Mallarmé, Valéry and Reverdy, poetics has been integral to poetry: not a system of codes, but 'poetic thought, reflection on its foundations' (Rueff, 2009). Glissant joins this tradition of poetic thought on poetry, which he diverts and decentres, subsuming it to the category of aesthetics. Glissant takes his idea of aesthetics from Reverdy (via Hegel) and repoliticizes it, 'particularizes' it, jolting it out of its still-rigid patterns. The above are clear stages in Glissant's thought on literary creation over the past forty years, which has continuously evolved in both direction and scope, always in 'unpredictable' ways.

9 This 'setting-in-relation' has led to a new concept of comparative literature, shifting it from its habitual paths (see Bassnett, 2006; Spivak, 2003; et al.). Indeed, the poetics of Relation (of which translation is a cornerstone) is itself redemptive in nature, redefining comparative literature and providing it with a profoundly political and aesthetic dimension which it previously lacked. Nor is this a mere reversal of perspectives (passing from the viewpoint of the 'dominator' to that of the 'subaltern'). Instead, it teases out the darker side of literature, which is in fact the means by which it brings light into the world: Glissant's concept of Relation comprehensively revisits the very grounds on which we evaluate and compare literatures. The poetics of Relation sets out a methodological basis for the comparative analysis of literary texts (resembling the global literary anthology assembled by Glissant (2010)). It is a comparative literature that has finally attained adulthood, self-generated and awaiting regeneration, brought up to date in the age of the tout-monde. 
it might at first appear. ${ }^{10}$ Glissant does not reject the principle of influence, he turns it into a principle of Relation (going so far as to speak of 'contamination'). In this sense, influence would be more a matter of re(-)cognition, of outcrops on the textual landscape, of ephemeral points of contact.

Faulkner, Mississippi, and indeed Glissant's entire critical output, thus exemplifies postcolonial criticism, all the more so in that it radically subverts the literary tradition which is its object. His critical essays, which cannot be viewed separately from his novels and poems, inflect the concept of literary tradition (overturning well-established generic categories such as the essay, novel, drama, poetry and so on, in the process), decentring it, increasing its breadth and rejecting those works which Glissant knows to be forever closed to the reader. ${ }^{11}$ In Soleil de la conscience, Glissant already asserted: 'Si l'œuvre est "bonne", on y respire, on y profite; si l'œuvre est "mauvaise", tout mouvement y est pour le lecteur impossible' [If the work is 'good', there is room for us to breathe, we can benefit from it; if it is 'bad', there is no possible room for movement by the reader] (Glissant, 1997: 40). He now takes up this idea once again in Faulkner, Mississippi: 'l'ouverture innombrable de l'œuvre [faulknérienne] a fait que chacun a pu, sans se trahir ni s'abolir dans ce qui n'était pas un modèle, emprunter quelque trace qui lui convenait, parmi celles qui se trouvaient là proposées' (Glissant, 1996: 344) [The unbounded openness of the work is such that anyone can find a suitable path among those Faulkner proposes without betraying or losing oneself' (Glissant, 2000: 254)].

What is more, in this book Glissant combines his aesthetic preoccupations with both the modernist and postcolonial principles which had previously often been constructed in opposition to each other, initiating a renewed

10 Patrick Chamoiseau returns to this subject in Un dimanche au cachot where Faulkner and Glissant figure among the ranks of great authors. He makes the following remark on the non-anxiety of influence: 'que si Faulkner l'a déjà fait, cela ne sert à rien de le refaire [...] que Cervantès, Joyce, Faulkner, Perse, Césaire, Glissant [...] nous ont ouvert des portes, [qui] [...] sont reliées entre elles, se relatent sans fin, et qu'un trésor baille à leurs entrecroisements' [that if Faulkner has already done it there is no point in doing it again [...] that Cervantes, Joyce, Faulkner, Perse, Césaire, Glissant [...] have opened the doors for us, [which] [...] are interconnecting, constantly leading to each other, and that a treasure is spilling out at their points of intersection] (Chamoiseau, 2007: 267-68). I am very grateful to Bernadette Cailler for having brought this text to my attention.

11 Faulkner, Mississippi does not itself belong to any stable genre: it is at once a travel diary, literary criticism, semi-fiction (with the intrusion of Mycéa, who is the chief interlocutor in the book and who also provides its 'ethical' voice, keeping a close eye on Glissant's intellectual and, some might say, already over-academic reasonings). 
dynamics of Relation between them. ${ }^{12}$ As a consequence, it is tempting to link Glissant's concept of opacity to modernist negativity, perceived by Adorno as the necessary and only guarantee of modernism's truth-content, where the autonomy of the modernist work of art represents neither a rejection of historical and political conflicts nor a formalism detached from human experience but a mode of realism based on the loss of experience; it is the degree of autonomy in the modernist work that allows it to exercise its critical power fully and, out of the depths of its negativity, to restore a form of hope to the world. Leaving aside Adorno's euro-centrism (which, in this revolutionary thinker, is almost too obvious to be convincing), theoretical links can be established between his principle of non-identity (which supports his negative dialectic, and rejects the homogenization imposed by the universalist principle of identity and the tyranny of eighteenth-century rationalism) and the Glissantian theory of non-history, of the trace, of the abyss, of perpetually deferred revelation, and of non-language ('notlanguage' in Absalom!). Glissant is at heart the great Negating writer, the writer of positive negativity (how else should we interpret poétique forcée [forced poetics], le déparler [ravings] and l'opacité [opacity]?), a positive negativity which emerges from the night, from traces, and, tragically, never regains its wholeness, even though he never abandons the waking dream of being made whole. ${ }^{13}$ Glissant's texts which deal with aesthetics, knowledge and poetics, while they differ from those of Adorno in certain respects, share with them a conviction that domination cannot be vanquished through a form of art which is too directly politically engaged. This was also the question addressed by his first novel, La Lézarde (1958), where political action and art were set in a parallel and sometimes conflicting relationship. For Glissant, the fight against forms of domination cannot be accomplished without running the risk of mediating those same

12 A number of significant books and articles have reinstated the link between postcolonial literature, modernism and aesthetics severed by the postmodernist drive of the 1990s: Lazarus, 1986; Gikandi, 1992; Quayson, 1999; and Nesbitt, 2003. It is also worth remembering the confusion which arises in many critical works between various modernist and avant-garde projects. Nor should we forget that it is only as a result of the work of Jacques Rancière (2004) that the term 'modernism' has come to be used in French in a way broadly similar to the English understanding of the term. To include Yeats and Joyce, Césaire and Reverdy in the same category, for example, is to disregard the differences between their aesthetic (and political) projects.

13 For an excellent analysis of the relationship between Adorno and postcolonial theory, see Bahri, 2003. On the role of the Negator in Glissant, see Cailler, 1988; Britton, 1999; and Chancé, 2002. For a lucid analysis of Adorno, see Jarvis, 1998 and Zuidervaart, 1991. 
forms, bringing about a crystallization of History. Negation provides the guarantee that the work of art does not unwittingly reproduce the very forms of domination it wishes to fight against. It is only in its power to negate 'what is' that the possibility of a 'concrete Utopia' can survive, pointing to a latent 'not yet' (Bloch) even in a present that is experienced as obscure and traumatized. ${ }^{14}$ For, however vertiginous the paradoxes of Adorno's aesthetics may be, he shares with Glissant the concern for struggle and truth which can still be associated with modernism: 'Surely it would be better for art to vanish altogether than to forget suffering, which is art's expression and which gives substance to its form' (Adorno, 2004: 338). The validity of Glissant's poetics and aesthetics is drawn from the original abyss, from the negativity on which his entire work is founded and which fuels his belief in the capacity of art to affect the course of our imaginings and therefore our practices to the extent that, whereas in Adorno the paradoxes of art cannot be resolved except in a world free of antagonisms, in Glissant paradox is replaced by the inextricable while antagonisms give way to Relation. Utopia in Adorno can only be negative and unrealizable, even if it is always desirable and necessary as the unattainable goal of humanity, science and art, because antagonisms cannot be resolved in the world as it is, endlessly reflected in the contradictions of modern art, whereas Glissant's conception of Utopia is closer to Bloch's (and that of Marcuse after him), remaining even in its very lack a Principle of Hope (Bloch, 1995), a concrete hope. This principle of hope, which is also seen as a prism of lucidity and a refusal of what is (namely, in the first instance, the condition of the colonized), remains a benchmark for his aesthetics and his work: 'Lutopie n'est pas le rêve. Elle est ce qui nous manque dans le monde' [Utopia is not a dream. It is what we lack in the world] (Glissant, 2005: 16). Utopia is that reservoir of innocence

14 The artist is the figure who proclaims that 'something' is missing in the artificial happiness promoted by the culture industry, the Aber Etwas fehlt, which can be heard in Brecht and Weil's dystopian opera Mahagonny (a possible source for Glissant's Mahagony?), opening up an abyss that offers salvation, the possibility of a 'true' happiness. There is a link to be made between Glissant's concept of Utopia and that established by Ernst Bloch in The Principle of Hope (Bloch, 1995), and both resemble those of Benjamin, Adorno and, more recently, Ricœur. For an overview of these theories, known as 'concrete' or 'negative' Utopias, see Europe 949, 2008. Ideas such as Benjamin's theory of History, the role of myth, the process of demythification, the relationship of myth with historical time and the community (in Benjamin and Adorno), the dichotomy of oral storytelling and the novel and, most of all, the new community/language which art still has the capacity to bring forth, can all be related profitably to Glissant. 
and opposition to ideology (Ricoeur, 1997) that gives strength to the poetic and political struggle: 'rudesse innocente de l'utopie'; 'l'utopie est notre seul Acte: notre seul Art' [the innocent ruggedness of Utopia; Utopia is our only Act, our only Art] (Glissant, 2005: 19, 27).

In Faulkner's version of modernism Glissant sees clearly that revolutionary techniques of writing are always motivated by a presupposition in the real world and are never external forms superimposed on supposedly stable historical material (such material does not exist). For Glissant, 'la technique moderniste est consubstantielle à la matière, au sujet traité' [modernist technique is consubstantial with its material, with its subject matter] (Magny, 1948: 48), and it provides the means to return to the unspoken of historical impossibility, that is to say, everything that would otherwise be submerged in the 'délire verbal' [verbal delirium] or 'déparler' [raving] that plagues the community of Martinique but which can, in turn, itself become a source of autonomous and authentic creation (Chancé, 2002). According to him, these modernist procedures 'ne mènent pas aux révélés absolus d'une Genèse, ce sont les détours infinis par quoi une digénèse trame ses traces et entre dans le conjectural du monde' (Glissant, 1996: 284) [tell us nothing absolute about how Genesis takes place. They are the endless detours by which a digenesis weaves its traces and Faulkner enters into the realm of the worldly conjectural (Glissant, 2000: 207)].

Faulkner's modernist writing techniques are listed exhaustively by Glissant. First, there are the three key techniques of accumulation, repetition and the circularity generated by the first two. Then there are the stylistic markers, the 'not only, but's, the 'not at all, but's and 'perhaps's, which qualify what Glissant describes as 'les touchers de conscience' (Glissant, 1996: 283) [strokes of consciousness (Glissant, 2000: 206)]. To these we must add the other techniques briefly mentioned by Glissant: preterition; the orality inherent to storytelling; the description of the effect before the cause; attention to typographical form and page layout; the points in the text where the style becomes that of a prose poem, where the text appears in a block with almost no punctuation. ${ }^{15}$ Glissant's accurate and perspicacious description of Faulkner's techniques is mirrored in his own works, for example in the extreme density of La Case du commandeur (Glissant, 1981b), the constant shifts in rhythm and style in Malemort (Glissant,

\footnotetext{
15 See Celia Britton's chapter on Faulkner in this volume, which refers to the essential characteristic of Faulkner's deferred writing: preterition or paralipsis, 'dire sans dire tout en disant' (Glissant, 2008: 63; 2009: 156) [saying without saying while saying].
} 
1975) and Mahagony (Glissant, 1987), the blocks of prose separated by short indents in Ormerod (Glissant, 2003), his use of italics in Le Quatrième Siècle (Glissant, 1964) and, invariably, in temporal arabesques, where chronology advances in spirals, not straight lines. These stylistic patterns in Glissant echo certain stylistic characteristics of Absalom! (Faulkner, 1936), Go Down Moses (Faulkner, 1942) and Intruder in the Dust (Faulkner, 1948), but never in a passive process of assimilation: on the contrary, fresh life is breathed into these occasional surface similarities whose role in the narrative is sometimes quite different from that in Faulkner's work - in this respect such passages should be described as pastiche ('in the manner of', borrowings of motifs and characteristics) or even parody (a more distanced reconfiguration of motifs). ${ }^{16}$ It is, rather, with respect to breathing and rhythm and to heuristic content (form being an integral part of the process of revelation and concealment which characterizes Glissant's poetics) that these similarities are worth pursuing further.

Faulkner and Glissant share an intuition that the poetic 'enfante des bouleversements qui nous changent' [gives birth to upheavals which transform us] (Glissant, 2005: 108). Poetry is what allows us to follow the trail back, to work our way through a gradual series of revelations: 'La poésie révèle dans l'apparence du réel, ce qui s'est enfoui, ce qui a disparu, ce qui s'est tari' [Poetry reveals in the semblance of the real, things that are hidden, that have disappeared, that have dried up] (Glissant, 2009: 102). And while poetry is - as for Césaire - a synonym for knowledge in Glissant's writing, this knowledge is never taken for granted; it is not founded on a fact to be appropriated, but on a dispossession, on non-knowledge, which he also calls 'un insu' (Glissant, 1996: 191) [an unknown (Glissant, 2000: 139)]. This unknown, this knowledge of non-knowledge, is, moreover, one of the core features of modernism. In Benjamin's rereading of Baudelaire we encounter the view that knowledge can only be produced through the destruction of experience, which modernity frames as ineffective and illusory. ${ }^{17}$ This

16 In his contribution to the Florida conference of February 2010, Michael Wiedorn judiciously pointed out that Glissant reads Faulkner in French, a situation with implications for the dilution of Faulkner's style: in fact, Faulkner, like Joyce, was fortunate enough to have excellent translators (Michel Gresset, François Pitavy) whose work came close to the originality of his style (translating 'wilderness' as 'brousse', for example). We should also remember Glissant's comments on translation as an operative function of the poetics of Relation in his various essays - in particular, Glissant, 1990.

17 On the concept of knowledge and non-knowledge (inspired by Bataille), see Weinstein, 2006. 
destruction gives narrative the power to found a new poetics 'non pas de la narration, mais du rapport du narré à l'indicible qui le porte' (Glissant, 1996: 192) [that is not narrative but creates a relationship between what is narrated and what is unsayable (Glissant, 2000: 140)]: writing as a resistant and opaque signifying form, not founded on a compromised reality, but capable of recreating a lost link, of bringing the trace to life.

Glissant understands himself through Faulkner's modernism, which he perceives as a deconstructive undertaking that is in fact an intentionally impossible act of historical reconstruction. It is only effective because of its repeated failure, for example in Absalom! and Go Down Moses, where writing, equipped with the full modernist toolkit, is made to serve an impossible archeological endeavour, always striving to work further back towards a tragic presupposition that nevertheless remains unknown 'parce que ce présupposé est à jamais insu, l'écriture, techniquement, se rassemblera en une série d'approches dont aucune ne conclut et dont le tout porte au vertige de l'inconnaissable' (Glissant, 1996: 195) [because this presupposition will never be known, the writing juggles a series of technical approaches, none of which reaches a conclusion and all of which spin into vertigo' (Glissant, 2000: 142)]. This dark side draws the reader in and generates the intangible quality of Faulkner's work, being none other than the hidden element of true suffering already apparent in other ways. Literature has no choice but to confront this unknown: 'le caché nous fait mieux ressentir le dévoilé ou le révélé. C'est "ce qu'on ne comprend pas" qui dans l'œuvre nous aide à approcher la masse sombre et lumineuse de ce que nous croyons avoir compris' (Glissant, 1996: 195) [What is hidden makes us feel what is disclosed or revealed all the more strongly. [...] it is 'what we don't understand' that helps us approach the dark and luminous mass of what we think we have understood (Glissant, 2000: 142)]. Glissant sets out a new poetics and offers his readers fresh knowledge and it is in this that both the risk and the challenge of his work are to be found. While Glissant pursues Faulkner's modernist project and while the latter allows us a greater understanding of the complexities and the issues at stake in Glissant's own work, this is because he uproots Faulkner's work from the atavistic tradition imposed on it by the critics, and, in doing so, redeems it. In his book, he chooses to approach Faulkner from an aesthetic point of view, despite his awareness of Faulkner's failings and because of his knowledge of how to expose them. He sets this essential question aside but does not deny its existence: 'la littérature prévaut sur le témoignage ou la prise de position, non parce qu'elle excède toute appréciation du réel, mais parce qu'elle en est l'approche la plus approfondie, la seule qui vaille finalement' (Glissant, 1996: 92) [literature matters more than making testimonies or taking sides, not because it exceeds all possible appreciation of the real, but because it is a 
more profound approach and, ultimately, the only one that matters' (Glissant, 2000: 64)]. Modernist literature does not disengage itself from reality nor does it cravenly abdicate responsibility when faced with the judgement of history: on the contrary, the whole of Glissant's book attempts to show that Faulkner's work orbits the abyss of the unsayable, which nevertheless leaves behind an indelible mark. Glissant's lucid analysis of Faulkner's atavistic racism offers no excuse for the latter but he refuses to condemn his work, seeing in it a chance of hope, an authenticity guaranteed by the suffering which it uncompromisingly allows to appear in all its nakedness, and by its capacity to 'negate' an unjust reality which still endures: 'l'œuvre de Faulkner mesure ce qu'il faudra de renversement dans les sensibilités avant que les nouveaux rapports, le nouveau vécu de la Relation, soient rendus délibérés. Ce renversement, l'œuvre de Faulkner y travaille, non par leçon de morale, mais par changer nos poétiques' (Glissant, 1996: 134) [[Faulkner's work] measures what reversals must occur in sensibilities before new alliances - the new experience of the Relation - can become deliberate. Faulkner's work struggles toward this change of direction, not through moral lessons, but by changing our poetics' (Glissant, 2000: 95-96)].

Ultimately, in his own particular dynamics of reversal, it is thus Glissant who puts Faulkner to the test. That this should involve so much opacity and so many obvious differences between the two writers is necessary: Glissant continues here, and no doubt concludes, the task he embarked on thirty years earlier in his Intention poétique, another revolutionary critical work, probably rivalled in the French language only by the critical works of Blanchot, Bonnefoy and Deguy. ${ }^{18}$ What is more, Glissant, in this book, re-evaluates aesthetics, transforming the modernist aesthetic and opening it up from within, freeing it of its atavistic content and proposing it as a new aesthetic which could be described as postcolonial.

In Faulkner, Mississippi, Glissant provides us with the tools to enter his own work whose opacity guarantees its resistance to appropriative readings. This resistance is that of language, reconstructed between the lines of 'official'

18 Despite the importance of Glissant's works, and despite the recent efforts of the Institut du Tout-monde, little attention has been paid to Glissant in French poetic and academic circles. Although remarkable, the poetry internet site created by Jean-Michel Maulpoix (www.maulpoix.net) nowhere mentions Glissant, and the same is true of Martin Rueff's theoretical work which brilliantly retraces the past forty years of poetic creativity in France through reference to the work of Deguy (Rueff, 2009). Very few French theorists of poetry have followed the example set by Michel Collot in his detailed examination of Glissant's poetry. 
language in La Lézarde, for example, where the multiple and complex voice of the narrator - 'j'entends l'ivresse du temps passé [...] mais les mots n'achèvent jamais de mourir, la rivière jamais n'achève de porter les terres vers la mer' (Glissant, 1958: 244) [I still hear the wild rejoicing of bygone days [...] But the words never finish dying; the river never ceases to carry its burden of earth towards the sea' (The Ripening: 1985: 180)] - repeats Addie Bundren's litany against words from As I Lay Dying (Faulkner, 1930), reformulating it, reinvesting the fallen words with their haunting power, their ability to preserve and bear traces. ${ }^{19}$ Or again, in the modulation and shifting of the narrative voices of Absalom! in his Quatrième Siècle, where Mathieu Béluse's constant interjections: 'mais tu vas trop vite' (Glissant, 1964: 213) [But you're going too fast (Glissant, 2001: 215)] merge into the 'touchers de conscience' (Glissant, 1996: 283) [strokes of consciousness (Glissant, 2000: 206)] of interior monologue: 'nous sentons que nous sommes trop légers sous ce poids [le passé], et pour remplir notre présence nous sommes trop vides dans cette absence, cet oubli' (Glissant, 1964: 58) [we feel that beneath this weight [of the past] we are too flimsy, and we are too empty in this absence, and forgetting to fill our presence' (The Fourth Century: 2001: 51)], Glissant quite simply creates the resonances of Relation, rendering concepts of influence and atavistic literary tradition obsolete. ${ }^{20}$ Ludic relationships are in no way excluded from this process (to which we should add the restorative function of humour in both writers), so long as the need to follow the trail of the trace and Mycéa's voice, ever enigmatic and ungovernable, enchanted and enchanting, remain the ethical benchmarks, the only true concern of Glissant's imaginary creation.

For as long as aesthetics continues to pursue the enigma of the trace, with the poetics of Relation as the practical manifestation of this quest, writing is protected from the risk of becoming monumentalized and ceasing to

19 'I learned that words are no good; that words don't ever fit even what they are trying to say [...] I knew that that word was like the others: just a shape to fill a lack [...] I would think how words go straight up in a thin line, quick and harmless, and how terribly doing goes along the earth, clinging to it' (Faulkner, 1955 [1930]: 92-93).

20 The rhythm created by Faulkner for Quentin and Shreve's breathless and breathy double narration in Chapter 7 of Absalom! (Shreve's 'get on with it's 'get on now's and 'go on's, which are echoed by Quentin's 'Wait's ‘Wait, I tell you!'s), is also employed again by Artémise and Mathieu in Tout-monde: 'Tout ça va trop vite [...] Attendez rien qu'un peu'; 'Attendez attendez' (Glissant, 1993: 211); 'Tout ça va trop vite' (ibid.: 223) [It's all going too fast [...] Wait just a little bit; Wait wait; It's all going too fast]. 
communicate, becoming a trace in its turn. It is indeed this 'trace-mémoire' [memory trace], to borrow Chamoiseau's term (Chamoiseau and Hammadi, 1994), which appears in Absalom! where we encounter an important definition of History framed, not in terms of documents and monuments, but as an evanescent trace.

And so maybe if you could go to someone, the stranger the better, and give them something, anything, it not to mean anything in itself and them not even to read or keep it, not even bother to throw it away or destroy it, at least it would be something just because it would have happened, be remembered even if only from passing from one hand to another, one mind to another, and it would be at least a scratch, something, something that might make a mark on something that was once for the reason that it can die someday, while the block of stone can't be is because it never can become was because it can't ever die or perish. (Faulkner, 1976: 105-06)

And Mycéa replies to this Faulknerian injunction in the clausula of Faulkner, Mississippi, where her voice blends dialogically with that of Glissant, inverting Beckett as it does so: 'non pas démontrer ni justifier, approcher tout au plus. Mais oui, dit-elle, la meilleure [approche] à jamais, la meilleure chaque fois' (Glissant, 1996: 347) [neither prove nor justify. The best you can do is reach an approximation. But, yes, she says, forever the best [approach], the best each time (Glissant, 2000: 256)].

Translated by Teresa Bridgeman.

\section{Works Cited}

Adorno, Theodor W. 2004. Aesthetic Theory. Trans. by Robert Hullot-Kentor. London: Routledge.

Bahri, Deepika. 2003. Native Intelligence: Aesthetics, Politics and Postcolonial Literature. Minneapolis and London: University of Minnesota Press.

Bassnett, Susan. 2006. 'Reflections on Comparative Literature in the Twenty-First Century'. Comparative Critical Studies 3.1-2: 3-11.

Benjamin, Walter. 1996. Selected Writings, Vol. 1, 1913-1926. Ed. and trans. by Marcus Bullock and Michael W. Jennings. Cambridge, MA: Harvard University Press.

Bleikasten, André. 2007. William Faulkner: une vie en romans. Croissy-Beaubourg: Éditions Aden.

Bloch, Ernst. 1995. The Principle of Hope. Trans. by Neville Plaice, Stephen Plaice and Paul Knight. Cambridge, MA: MIT Press. 
Britton, Celia M. 1999. Edouard Glissant and Postcolonial Theory: Strategies of Language and Resistance. Charlottesville and London: University of Virginia Press.

Cailler, Bernadette. 1988. Conquérants de la nuit nue: Édouard Glissant et l'H(h)istoire antillaise. Tübingen: Gunter Narr.

Chamoiseau, Patrick. 2007. Un dimanche au cachot. Paris: Gallimard.

Chamoiseau, Patrick, and Rodolphe Hammadi. 1994. Guyane: traces-mémoires du bagne. Paris: Caisse nationale des monuments historiques et des sites.

Chancé, Dominique. 2002. Édouard Glissant: 'un traité du déparler'. Paris: Karthala.

Chrétien, Jean-Louis. 2009. Conscience et roman. Paris: Éditions de Minuit.

Dash, J. Michael. 1998. The Other America: Caribbean Literature in a New World Context. Charlottesville and London: University of Virginia Press.

Europe 949. 2008. T. W. Adorno et E. Bloch. May 2008.

Faulkner, William. 1955 [1930]. As I Lay Dying. In The Best of Faulkner. London: Reprint Society.

—. Requiem for a Nun. 1975 [1951]. New York: Vintage Books.

—. Absalom, Absalom! 1976 [1936]. Harmondsworth: Penguin Books.

—. A Fable. 1977 [1954]. New York: Vintage Books.

—. Go Down Moses. 1991 [1942]. New York: Vintage Books.

-. Intruder in the Dust. 1991 [1948]. New York: Vintage Books.

Gikandi, Simon. 1992. Writing in Limbo: Modernism and Caribbean Literature. Ithaca, NY: Cornell University Press.

Glissant, Édouard. 1958. La Lézarde. Paris: Éditions du Seuil [English translation by J. Michael Dash: The Ripening. London: Heinemann, 1985].

—. 1964. Le Quatrième Siècle. Paris: Éditions du Seuil. English translation by Betsy Wing. The Fourth Century, 2001. Lincoln and London: University of Nebraska Press.

—. 1969. L'Intention poétique. Poétique II. Paris: Éditions du Seuil.

—. 1975. Malemort. Paris: Éditions du Seuil.

—. 1981a. Le Discours antillais. Paris: Éditions du Seuil.

—. 1981b. La Case du commandeur. Paris: Éditions du Seuil.

—. 1987. Mahagony. Paris: Éditions du Seuil.

—. 1990. Poétique de la relation. Poétique III. Paris: Gallimard.

—. 1993. Tout-monde. Paris: Gallimard.

-. 1996. Faulkner, Mississippi. Paris: Stock. English translation by Barbara B. Lewis and Thomas C. Spear. Faulkner, Mississippi, 2000 [1999]. Chicago, IL and London: University of Chicago Press.

—. 1997 [1956]. Soleil de la conscience. Poétique I. Paris: Gallimard.

-. 1999. Sartorius: le roman des Batoutos. Paris: Gallimard.

-. 2003. Ormerod. Paris: Gallimard. 
-. 2005. La Cohée du Lamentin. Poétique V. Paris: Gallimard.

—. 2006. Une nouvelle région du monde. Esthétique I. Paris: Gallimard.

-. 2008. (with Alexandre Leupin). Les Entretiens de Baton Rouge. Paris: Gallimard.

-. 2009. Philosophie de la relation: poésie en étendue. Paris: Gallimard.

- 2010. La terre, le feu, l'eau et les vents: une anthologie de la poésie du tout-monde. Paris: Galaadé.

Jarvis, Simon 1998. Adorno: A Critical Introduction. New York: Routledge.

Ladd, Barbara. 2003. 'Faulkner, Glissant, and a Creole Poetics of History and the Body in Absalom, Absalom! and A Fable'. In Robert W. Hamblin and Ann J. Abadie (eds), Faulkner in the Twenty-first Century. Jackson: University of Mississippi Press: 31-49.

-. 2007. Resisting History: Gender, Modernity, and Authorship in William Faulkner, Zora Neale Hurston, and Eudora Welty. Baton Rouge: Louisiana State University Press.

Lazarus, Neil. 1986. 'Modernism and Modernity: T. W. Adorno and Contemporary White South African Literature'. Cultural Critique 5: 131-64.

Loichot, Valerie. 2003. 'Glissant, Yoknapatawpha'. Mississippi Quarterly 57.1: 99-111.

Magny, Claude-Edmonde. 1948. L’Age du roman américain. Paris: Éditions du Seuil.

Mathews, John T. 2004. 'Recalling the West Indies: From Yoknapatawpha to Haiti and Back'. American Literary History 16.2: 238-62.

Maulpoix, Jean-Michel. n.d. <http://www.maulpoix.net>. Consulted 1 August 2010.

Nesbitt, Nick. 2003. Voicing Memory, History and Subjectivity in French Caribbean Literature. Charlottesville and London: University of Virginia Press.

Quayson, Ato. 1999. Postcolonialism: Theory, Practice or Process? Cambridge: Polity Press.

Rancière, Jacques. 2004. Malaise dans l'esthétique. Paris: Galilée.

Ricœur, Paul. 1997. L'Idéologie et l'utopie. Paris: Éditions du Seuil.

Romano, Claude. 2005. Le Chant de vie: phénoménologie de Faulkner. Paris: Gallimard.

Rueff, Martin. 2009. Différence et répétition: Michel Deguy, situation d'un poète lyrique à l'apogée du capitalisme culturel. Paris: Hermann.

Schwartz, Lawrence S. 1988. Creating Faulkner's Reputation: The Politics of Modern Literary Criticism. Knoxville: University of Tennessee Press.

Spivak, Gayatri Chakravorty. 2003. Death of a Discipline. New York: Columbia University Press.

Staiger, Emil. 1991 [1946]. Basic Concepts of Poetics. Trans. by Janette C. Hudson and Luanne T. Frank. University Park: Pennsylvania State University Press. 
Weinstein, Philip M. 1996. What Else but Love? The Ordeal of Race in Faulkner and Morrison. New York: Columbia University Press.

-. 2006. Unknowing. Ithaca, NY: Cornell University Press.

-. 2009. Becoming Faulkner: The Art and Life of William Faulkner. New York: Oxford University Press.

Zuidervaart, Lambert. 1991. Adorno's Aesthetic Theory. Cambridge, MA: MIT Press. 


\title{
The Theme of the Ancestral Crime in the Novels of Faulkner, Glissant and Condé
}

\author{
Celia Britton
}

William Faulkner, Édouard Glissant and Maryse Condé all come from that part of the world that we can define as the American Tropics, and therefore share a common history of plantation slavery. Within that history, however, they occupy very different positions - Faulkner as the descendant of slaveowners, Glissant and Condé as the descendants of slaves. In addition, the American South and the Caribbean have very different attitudes towards the question of racial mixing, pejoratively known as miscegenation in the United States and positively as métissage or creolization in the Caribbean. The South's fear of miscegenation leads to an obsession with what Glissant calls 'filiation', that is, maintaining clear continuous lines of descent, especially male descent, which he sees as the opposite of creolization; these two antagonistic principles are a prominent theme in many of his essays (see, e.g., Glissant, 1996b).

Glissant has also written on Faulkner throughout his career, culminating in 1996 with Faulkner, Mississippi (Glissant, 1996a; henceforth FM), and the opposition and interplay of filiation and creolization are central to his account of Faulkner. He sees Faulkner's novels as showing the inevitable perversion of filiation, and the impossibility of founding a 'pure' lineage. Thus, Faulkner's Absalom, Absalom is a particularly important text for Glissant, because of its hero Thomas Sutpen's desperate desire to found a lineage, and the tragic consequences of this $(F M, 151)$. In other words, he reads Faulkner's work as dominated by the issue of the origin of Southern society; Faulkner's sense of the damnation of the South, he argues, stems from the impossibility of founding a legitimate filiation - and this in turn 
is impossible because the whole society has been brought into existence by a crime: an 'original sin'.

What this crime is, however, is never entirely clear. Looking at Faulkner's work as a whole, Glissant shows how it sometimes appears to be simply miscegenation: 'Dans la métaphysique délirante du Sud, il est une logique indéniable: que c'est impossible de fonder lignée à partir du mélange' (FM, 122-23) [In the surreal metaphysics of the South, miscegenation truncates the family line (Glissant, 2000: 87)]. Elsewhere, however, the 'curse' might be something the settlers brought with them to America (FM, 163); or it might stem from the way in which they acquired land (FM, 163-64); but this - stealing the land from the native Americans - is in turn juxtaposed with another original sin: the institution of slavery. Thus, after evoking the first question of how Faulkner is to represent the crime of stealing the land, Glissant adds: 'S'ajoute une autre béance [...] comment comprendre ou au moins envisager cette "damnation" du Sud? Est-elle liée à l'obscur enchevêtrement de l'esclavage, de ses racines, de sa tourmentée histoire?' [To all this, a gaping wound is added [...] How can one understand, or at least envision, the South's "damnation"? Is it connected to the South's dark entanglement with slavery, inextricable from its roots and its tormented history? (Glissant, 2000: 22)] - and concludes that Faulkner never gives an answer to these 'questions primordiales' (FM, 37) [primordial questions (Glissant, 2000: 22)].

So there are three possible candidates for the status of the original sin: miscegenation, the theft of the land, and slavery. Throughout Faulkner, Mississippi, they reappear in varying combinations: miscegenation is the result of slavery - 'la damnation, le métissage, né du viol de l'esclavage' $(F M, 124)$ [the damnation and miscegenation born of the rape of slavery (Glissant, 2000: 88)] - but is that the only reason why slavery is a crime? In fact, slavery is more often seen as a parallel crime to the appropriation of the land, a 'perversion', which undermines the attempt to found a legitimate community, but one which is 'liée (sourdement, obscurément), à une injustice, une oppression, en l'occurrence, l'esclavage' (FM, 169) [tied (secretly and nebulously) to injustice and oppression - namely, slavery (Glissant, 2000: 122)]. The two crimes are brought together in Go Down, Moses, where the Indian chief sells to the white settlers both the land which is not his to sell, and slaves $(F M, 165)$. But in general terms there is no necessary link between them.

Moreover, none of these entangled possible causes is ever stated explicitly. They combine to create a pervasive sense of damnation and rottennness, as in Hamlet's Denmark (FM, 181); but 'Faulkner ne le dit jamais (le criant si souvent, obscurément), parce qu'il souffre dans sa chair (dans son Sud) de le penser vraiment' (ibid.) [Faulkner never says this (he shouts it out indistinctly 
every so often) because he suffers in his flesh (his South) from thinking in this way (Glissant, 2000: 132)]. Here, Glissant raises the question of how Faulkner's own position affects his representation of Southern society, and argues that because of his implication in and intense emotional attachment to the South his novels cannot confront the question openly. As a citizen, Faulkner shared the conventionally loyal and racist views of the Southern plantocracy in general. In his writing, however, the conflict between his moral principles - in particular, his hatred of injustice - and his social position produces a fundamental ambiguity of which he does not seem to be fully conscious (FM, 308-09). Thus, Faulkner is not in control of his writing $(F M, 137)$, which as a result both reveals and conceals the original crime(s), constantly gesturing towards a truth whose revelation is constantly deferred: 'ce que l'écrivain William Faulkner s'est attaché, avec une si sauvage ténacité, à occulter tout en le révélant: le différé de la damnation du $\operatorname{Sud}(F M, 28)$ [what led the writer William Faulkner, with such savage tenacity, to hide even while revealing it: the deferral of the South's damnation (Glissant, 2000: 15)].

This 'différé' is, according to Glissant, a major structural principle of Faulkner's work. It underlies various prominent features of his writing, such as the curious indeterminacy of his characters $(F M, 37-38)$ and the inconclusive nature of his narratives $(F M, 53)$. But its central dynamic is the concealment-revelation of the secret crime: 'Indiquer et dérober un secret ou une connaissance, c'est-a-dire en différer le relèvement [... ] ce sera le motif, pour l'essentiel, des modes techniques autour desquels s'organisera son écriture' $(F M, 14)$ [To point out and to hide a secret or a bit of knowledge (that is, to postpone its discovery): this is [...] the motif around which his writing is organised (Glissant, 2000: 6)]. Thus the crime is figured in the novels by a secret truth buried in the past and only revealed towards the end of the novel, after a long and convoluted process of partial disclosures, hints and clues; but, even then, the revelation of this particular secret, for example Sutpen's first marriage to the not-wholly-white Eulalia Bon in Absalom, Absalom - is only implicitly and ambiguously connected to the basic crime which causes the damnation of the South. This kind of compulsive ambiguity and deferment is reminiscent of the theory of the Marxist critic Pierre Macherey, with his emphasis on the determining force of the 'silences' in the work; in the chapter of his Pour une théorie de la production littéraire entitled 'Dire et ne pas dire' (Macherey, 1966: 105-10), he argues that what is overtly present in the literary work emerges from a 'fond de silence' [background of silence], which is 'ce qui donne un sens au sens' [what gives a meaning to the meaning] (ibid.: 106). ${ }^{1}$

1 Macherey's theory has been adapted to a specifically postcolonial context by Gayatri Spivak (Spivak 1988: 286). 
The work says what it does because of what it cannot say, and this structure is produced by a contradiction between the author's ideology, determined by his or her class position, and the ability of literary form to distance and put into question that ideology.

As Macherey would, Glissant explains Faulkner's work as determined by his social position as a member of the Southern white landowning classes in the lengthy aftermath of their defeat in the Civil War. Had Faulkner not been so loyal to traditional white Southern society and so troubled by its decline, he would not have needed to repress or 'différer' the truths of its original sins. Therefore, despite the fact that Faulkner and Glissant are both formed by their history of plantation slavery in the American Tropics, one would not expect to find any similarities between their novels, because their social positions within this geographical-historical complex are so different: as a black descendant of slaves, Glissant has no reason to feel implicated in the crimes of the white plantation owners.

In fact, however, critics such as J. Michael Dash and Chris Bongie, while also stressing the differences between the two writers, have argued that Glissant's early fiction is heavily influenced by Faulkner (Dash, 1995: 74-79; Bongie, 1998: 167-69, 189-93). The clearest example of this is the novel which Bongie describes as 'Glissant's resolutely Faulknerian Quatrième Siècle' (Bongie, 1998: 167). In their discussion of Le Quatrième Siècle, both critics point to the overwhelming influence of the past on the present - a past, however, that cannot be represented straightforwardly or with any certainty (Dash, 1995: 74-75; Bongie, 1998: 189). Dash adds to this the concern with filiation and legitimacy, and conversely with interracial contact (Dash, 1995: 75); Bongie notes 'the importance of family genealogies' to both Le Quatrième Siècle and Absalom, Absalom (Bongie, 1998: 167-68), and mentions Glissant's analysis of the secret and its revelation in Faulkner's novels (ibid.: 167).

There is, however, another Faulknerian echo in Le Quatrième Siècle, which relates more directly to Glissant's analysis in Faulkner, Mississippi: the motif of the ancestral crime or the 'original sin'. One of the more surprising features of Le Quatrième Siècle is that in it Glissant chooses to appropriate and rework Faulkner's obsession with the crime that lies buried at the source of a community's evolution over time; the crime, in other words, that is 'original' in the sense that it has to do with the foundation of a lineage - in fact, in Le Quatrième Siècle, of two lineages. The novel tells the stories of two families who are descended from two African captives brought to Martinique on the same slave ship; the fact that we never learn their original African names is in itself a sign that transportation breaks the chain of filiation and so necessitates the founding of new lineages, named as the Longoués and the Béluses. The first Longoué and the first Béluse are enemies because of 
something that happened in Africa before they were captured, but for most of the narrative we do not know what that was. Only the narrator, Papa Longoué, knows; and he does not disclose it to his listener, Mathieu Béluse, until three-quarters of the way through the novel (Glissant, 1964: 245-46), when we and Mathieu learn that the two African ancestors were once close friends, but that after 'Longoué' was chosen to be the new chief of the tribe 'Béluse', out of envious rage, sold his friend to the slave raiders - but then was also taken himself, and they ended up on the same ship. The whole Béluse family, in other words, is descended from the man who betrayed his friend by selling him into slavery. This, then, is the ancestral crime that haunts $L e$ Quatrième Siècle. The similarities with Faulkner are clear: the narrative of founding a new lineage, not here as a result of colonization but of the trauma of transportation (hence the novel's repeated emphasis on the theme of 'enracinement' [rootedness]); and, particularly, the fact that the Béluse lineage is based on an original crime that is secret, unknown to the descendants and revealed only belatedly and briefly.

It does not follow, however, that Glissant's novels are also driven by the principle of the 'différé, the compulsive, constrained need to 'say without saying' that drives Faulkner's tortuous scenarios of gradual revelation; Glissant himself is not caught up in the moral and social contradictions that in his reading of Faulkner's work underlie the dynamic of the 'différé'. One indication of this is the contrast between Faulkner's lack of clarity concerning the nature of the original crime - hesitating, as I have shown, between slavery, miscegenation and the theft of the land - and the way in which in Glissant's novel it is quite unambiguously defined as African complicity in slavery, with a lucidity which suggests a much freer, less constrained authorial position.

At several points in Faulkner, Mississippi, however, Glissant emphasizes his view that the 'différé' is the most positive feature of Faulkner's writing, because the fracture that it introduces into the novels opens them up to the possibility of future change, including an intuition of creolization ( $F M$, $225-26,304-05)$. This may explain why, in addition to his reworking of the story of the original crime, Glissant also adopts the 'différé' as a structural principle. The revelation of Béluse's treachery in Le Quatrième Siècle is deferred until almost the end of the novel, just as the revelation of Charles Bon's mixed blood is in Absalom, Absalom. In Glissant's novel, however, the deferral strikes the reader less as an obscure impulse to delay or play down the truth than as a calculated mise en scène of repression: no longer the author's repression, in other words, but that of the characters. As in Glissant's reading of Faulkner, the repression is to do with slavery; unlike in Faulkner's case, however, it is not the result of guilt: there is no reason why 
the descendants of slaves (apart from individuals such as Béluse who raise the sensitive issue of African complicity in it $)^{2}$ should feel guilty about slavery. But Glissant has elsewhere written a great deal about their repression of the shame of slavery and the importance of overcoming it, most recently in Mémoires des esclavages. In this text he makes a direct connection between Faulkner's 'différé', now described as 'une nouvelle technique de l'écriture et un style nouveau, qui sont bien de dire sans dire tout en disant' [a new writing technique and a new style, which are to say without saying while still saying] (Glissant, 2007: 61; italics in original), and slavery, not just in Faulkner's work but in a far more general manner: no one who has been in any way implicated, however distantly, in any system of slavery, he argues, is capable of having a normal, 'neutre ou sereine' [neutral or serene], memory of it (ibid.: 63). Rather, he continues in a long italicized sentence,

Nous avons à nous dire tout esclavage, parce que nous essayons d'être lucides et d'être participants, sans nous le dire pourtant, parce que dans tous les cas nous en avons honte [...], et le disant quand même, parce que nous tenons au sens du temps et à la signification des histoires des peuples. ${ }^{3}$ (Glissant, 2007: 63-64)

In this sense the deliberate appropriation of Faulkner's 'différé' allows Glissant to stage the different drama of the slaves' descendants' repression of the trauma of slavery. But he also makes another use of it, one that is far more ironic. In Le Quatrième Siècle the deferred revelation of the original Beluse's crime is strangely anti-climactic: on the one hand the reader finally finds out the reason for the enmity between Longoué and Béluse, but the impact of the revelation is immediately followed by the realization that it is simply not relevant to the present-day characters' lives: referring to the slave ship which brought the two ancestors to Martinique, Papa Longoué finishes his

2 It is worth noting, however, that in a brief chapter in La Case du commandeur Glissant returns to this theme, tracing another genealogy, that of the Celat family, back to the same crime: their ancestor Odono is one of two friends who give themselves the same name, but then fall in love with the same woman; out of jealousy, one of them sells the other into slavery (Glissant, 1981: 138-42). As in the earlier novel, both end up in Martinique. But here no one knows which one was the victim and which the betrayer; the guilt of complicity in slavery is in this case not limited to one particular individual, but hangs ambiguously over the community as a whole.

3 'We have to speak to each other about all slavery, because we try to be lucid and engaged, yet without speaking about it, because in every case we are ashamed of it [...], and yet still speaking about it, because we care about the sense of time passing and the significance of the peoples' histories.' 
story by saying 'Mais lequel ici se souvient du bateau?' (Glissant, 1964: 247) [But who here remembers the boat? (Glissant, 2001: 250)]. This ironic, empty anticlimax is the sign of a conception of history which is very different from Faulkner's. On the one hand, Glissant accuses Faulkner of depriving black people of their history, criticizing "cette manière de "chosification" qui "sort" une communauté de son histoire' (FM, 84) [We know how reductive objectification "removes" a community from its context (Glissant, 2000: 58)]; and his own novels very consciously reinstate black people as agents of history. But while Le Quatrième Siècle does indeed emphasize the need to retrieve a lost history, it accords equal importance to the ability to leave it behind: as Mycéa says, 'le fait est qu'il faut apprendre ce que nous avions oublié, mais que, l'apprenant, il faut l'oublier encore' (Glissant, 1964: 285) [the fact is we have to learn what we have forgotten, but that, learning it, we have to forget it again (Glissant, 2001: 291)]. Thus, whereas the South for Faulkner is trapped in a static historical impasse, Glissant's characters have the 'resilience and creativity', in Dash's words, to instigate change. ${ }^{5}$

Moreover, the way in which Le Quatrième Siècle demonstrates that time moves on is centrally to do with the original crime of the first Béluse. There is no indication that Mathieu feels responsible for, or shocked by, the betrayal perpetrated by his ancestor. The enmity between the families dies out and Papa Longoué 'adopts' Mathieu, because his own son has been killed fighting in the First World War. Thus, while his situation as the last of his line could be seen as an eminently Faulknerian example of failed filiation, here the failure is repaired by the adoption of the descendant of the original traitor Béluse; and this in turn means that where Glissant differs most strikingly from Faulkner is in the complete absence of the idea of damnation. Indeed, the Béluse family, far from being cursed, develop and thrive, adapting to new

4 As Bongie notes, Le Quatrième Siècle 'critically supplements [Absalom, Absalom], in its revisionist emphasis on the centrality of a black experience that remains for the most part on the silent or inarticulate margins of the Southern writer's oeuvre' (Bongie, 1998: 189) and 'offers us the hope of a solution that, as Glissant points out, is apparently absent from Faulkner's novels ([L'Intention poétique], p. 178) [...] in which the past becomes the redemptive ground out of which a different set of relations - and a revolutionized future - might be thought to emerge' (ibid.: 191).

5 'There is generally a resilience and creativity in Glissant's characters that make them very different from Faulkner's doomed protagonists' (Dash, 1995: 74). Dash also contrasts Glissant's 'open-ended universe' (ibid.: 77) with Faulkner's atmosphere of doom. 
historical circumstances: it is the Longoués, descended from the original innocent victim, who die out as a distinct lineage.

But this - the end of the Longoué filiation - does not matter: because, as we read on the last page of Le Quatrième Siècle, they are somehow diffused into the lives of everyone else: 'Taris, les Longoué reposaient en tous .... It is also extremely significant that the two examples which the text goes on to give of this process of diffusion concern, first, the descendants of the original enemy, Béluse, and secondly of the mixed-race Targin family: 'Dans un Béluse, dont le vertige et l'impatience portaient la connaissance jusqu'au bord du chemin où elle était bientôt partagée entre tous. Dans un Targin, corps impavide, créé pour l'acte' (Glissant, 1964: 287) [The Longoués who had run dry were buried in everyone. [...] In a Béluse whose exhilaration and impatience took knowledge right to the edge of the road where soon it was shared with everyone. In a Targin, an impassive body created for action (Glissant, 2001: 293)]. Filiation, in other words, has given way to the creolization that is so antipathetic to Faulkner $(F M, 117)$. Creolization has 'mixed up' the original African lines of filiation and given them new sources of strength, as Mycéa reflects: 'Puisque la mer avait brassé les hommes venus de si loin et que la terre d'arrivage les avait fortifiés d'une autre sève' (Glissant, 1964: 285; my italics) [Because the sea had intermingled the men who had come from so far away, and the land to which they were delivered had strengthened them with different sap (Glissant, 2001: 292)]. Faulkner's sense of damnation, in other words, is dependent upon the supremacy of filiation, which in Glissant's fiction, as in his essays, gives way to the reality of creolization in which the notion of an ancestral curse affecting subsequent generations of one particular family can no longer be sustained.

Maryse Condé's allusions to Faulknerian themes in her novels are equally ironic, but differ from Glissant's in that she is not at all interested in the idea of founding a lineage: the hidden crimes, in her case, are not original - but they are ancestral. Also, unlike Glissant, Condée has not written extensively on Faulkner, but in interviews has spoken of his influence on her novels. Critics such as Michael Lucey (1992), and indeed Condé herself (Pfaff, 1996: 74), have linked her Traversée de la mangrove to Faulkner's As I Lay Dying because of their structural similarity: multiple interior monologues organized around a death. ${ }^{6}$ But elsewhere Condé emphasizes that her interest in Faulkner centres

6 In fact the similarities are fairly limited: the interior monologues in Traversée take place simultaneously during the 'veillée' of Sancher, while those of As I Lay Dying follow each other over a period of time and are more concerned with present events than memories of the past; also the character of Addie Bundren is not a source of mystery in the way that Sancher is. 
on the notion of a transgression and guilt that affect people who have not committed the transgression themselves, but in some sense inherited it. ${ }^{7}$ This is a theme which is far more prominent in Absalom, Absalom than in As I Lay Dying; and there are in fact close links between Traversée de la mangrove and Absalom, Absalom. Traversée alludes to Faulkner's novel in the name of Mira's son: Quentin, like Quentin Compson, one of the narrators of Absalom, Absalom, but also a child who will never be able to get to know his father Sancher, just as Charles Bon (for different reasons) never gets to know Thomas Sutpen. More generally, a comparison of Absalom, Absalom with Condé's Traversée de la mangrove allows us to see that the latter constitutes another reworking, parallel to Glissant's, of the theme of the ancestral crime.

For instance, Condés presentation of miscegenation bears a distinctly ironic relation to Faulkner: it used to be a crime - the white ancestor of the Lameaulnes family had to flee Martinique for Guadeloupe because he married a black woman in 1904 (Condé, 1989: 20) - but is no longer; the mulatto Lameaulnes family are now the richest and most socially powerful in the whole village, and we are told that 'dans la Guadeloupe d'aujourd'hui, ce qui comptait, ce n'était plus la couleur de la peau [... ] Non, ce qui comptait, c'était l'argent' (Condé, 1989: 135) [For what matters in today's Guadeloupe is no longer the colour of your skin [...] No, what matters is money (Condé, 1995: 108)]. Conversely, the elderly Man Sonson is angry with her son for marrying a white woman, but he laughs at her and she reflects that 'Peut-être que ces mots-là, noirs, blancs, ne signifient plus grand-chose!' (Condé, 1989: 82) [Perhaps those words, black and white, no longer mean anything! (Condé, 1995: 61)].

In Absalom, Absalom, filiation is undermined not only by miscegenation, but also by incest. Sutpen's repudiation of his first wife and son - Eulalia and Charles Bon - has tragic consequences not only for Charles but also for Judith and Henry, Sutpen's son and daughter by a second marriage, because the secret of Charles's parentage makes possible his engagement to his half-sister Judith, in other words raising the possibility of incest, and leading ultimately to his murder by Henry. In fact, throughout most of the novel, incest is the central issue regarding guilt; only near the end do we

7 'Transgression and guilt constitute one of the profound and essential themes of any literature. If you consider Faulkner, whom I have read quite a bit, you notice that he depicts many characters affected by a fault that is not within, but rather outside them, in the community to which they belong [...]. What interests me is the anguish of human beings who [...] wonder whether they are here for a reason that escapes their understanding, such as a transgression committed at some previous time' (Pfaff, 1996: 51). 
learn, in a typical example of 'le différé', why Sutpen repudiated Eulalia: that is, he discovered that she, and therefore also Charles, was of mixed race. So, in gradually uncovering its layers of secrets, the novel intertwines miscegenation and incest as parallel sexual crimes, both threatening the ideal goal of legitimate filiation. While miscegenation in this instance is ultimately seen as 'worse', incest has an ominously pervasive quality that makes it equally sinister: in Absalom, Absalom, the Charles-Judith relationship is echoed by strong suggestions of incestuous feelings between Judith and Henry. ${ }^{8}$

Traversée de la mangrove, on the other hand, features a prominent incestuous relationship between Mira and her half-brother Aristide. Here incest is not a horrifying possibility, but an actual relationship which has been going on for some time; nor is it the unknowing consequence of a secret or a misunderstanding; and it is itself not a secret but is generally known throughout the village (Condé, 1989: 180). One can see it as a metaphor for the closed community of Rivière au Sel - Mira prefers Sancher to Aristide because 'il venait d'Ailleurs' (Condé, 1989: 63) [he came from Elsewhere (Condé, 1995: 43)] - just as for Faulkner it serves as a metaphor for the inbreeding of the white South. But Condé's closed community is a threat not to filiation but to individual self-determination: Aristide's reaction to the end of his 'guilty love' for Mira is to decide to leave: 'Ne prenait-il pas le départ de sa vraie vie?' (Condé, 1989: 80) [Wasn't he off to begin his real life? (Condé, 1995: 59)]. Above all, the presentation of this incestuous relationship is extremely undramatic - it attracts disapproval ('son amour peu ordinaire' (Condé, 1989: 73) [his rather particular brand of love (Condé, 1995: 52)]), but nothing like the kind of horror that attaches to it in Absalom, Absalom. Loulou, the authoritarian father of Aristide and Mira, does not try to stop it, for example (Aristide even thinks his father is jealous; Condé, 1989: 80) and Dinah merely prays that God will forgive Mira (ibid.: 107). Incest is seen as embarrassing and rather unhealthy, but not as a terrible crime which must be prevented at all costs.

However, there are ancestral crimes in Traversée de la mangrove, and they have more indirect but nevertheless intriguing connections with other aspects of Absalom, Absalom. The tragedy in Faulkner's novel is in actual fact precipitated not by Eulalia's racial status per se but its consequence, that is, Sutpen's decision (although he does not see it as a choice) to repudiate both her and their child; and this finds an echo in Traversée de la mangrove's theme of parents who reject or mistreat their children, or whose children suffer because of their misdeeds. Dodose believes that her son's cerebral haemorrhage,

8 The temptation of incest also hovers over brother-sister relations in other novels by Faulkner, such as Quentin and Caddy in The Sound and the Fury. 
which leaves him permanently brain damaged, is God's punishment for her adultery (Condé, 1989: 211-12); when Mira becomes pregnant by Sancher, her stepmother Dinah interprets this as God's punishment for her adultery with Sancher: 'Les malheurs des enfants sont toujours causés par les fautes cachées des parents' (Condé, 1989: 104) [The misfortunes of the children are always caused by the secret sins of the parents (Condé, 1995: 79)]; and Rosa, Vilma's mother, echoes this comment when (just as Dodose does with Sonny; Condé, 1989: 214) she blames herself for not having loved Vilma enough: 'C'est moi qui suis coupable, responsable de tout ce malheur. Car, il ne faut pas chercher, le malheur des enfants est toujours causé par les parents' (Condé, 1989: 166) [I am guilty, I am the one to blame for all this unhappiness. For you don't need to look very far: a child's misfortunes can always be traced to the parents (Condé, 1995: 136)]. It is typical of Condé that the ancestral curse assumes the more twentieth-century, psychologistic form of the cycle of abuse: Rosa cannot love her children because she was not loved herself (Condé, 1989: 169, 171); Loulou treats his sons harshly because he himself was rejected by his mother (ibid.: 122-23), and so on.

However, Traversée's central example of the Faulknerian ancestral curse is rather different. It concerns Sancher: all the men in his family die prematurely, supposedly because of a crime that one of his ancestors committed. We learn that this crime was committed in Guadeloupe, and that Sancher has come there in order to die, with no children to succeed him and thus to 'terminer une race maudite' (Condé, 1989: 87) [put an end to a race that's cursed (Condé, 1995: 66)]: in other words, to break for ever the chain of filiation. Fragments of the ancestor's story gradually emerge, and Sancher's conviction that his death is imminent because of the curse put on the family is repeated several times. Also, Sancher is terrified of Xantippe, the mad outcast who lives in destitution outside the village and whom he sees as a figure of avenging death, saying to him: 'Est-ce que tu ne connais pas le pardon? La faute est très ancienne. Et puis, je n'en suis pas l'auteur direct' (Condé, 1989: 118) [Don't you know the meaning of forgiveness? The fault is a very ancient one. I'm not the one to be blamed directly (Condé, 1995: 91)]. But the exact nature of the original crime remains a mystery to the reader and to the other characters for most of the novel: there is just one rumour, cited quite late on, that it concerns slavery: 'A l'en croire, Francis Sancher se prendrait pour le descendant d'un béké maudit par ses esclaves et revenant errer sur les lieux de ses crimes passés' (Condé, 1989: 224) [Going by what she said, Francis Sancher thought himself the descendant of a white Creole planter, cursed by his slaves, who had come back to haunt the scenes of his past crimes (Condé, 1995: 186)]. But it is only in the last of the main chapters of the novel, at the end of Xantippe's interior monologue, that it acquires the status of a real 
event rather than a lurid rumour, and that it is revealed as the torture and massacre of the ancestor's slaves. Xantippe has found the evidence: 'Je sais où sont enterrés les corps des suppliciés. J'ai découvert leurs tombes sous la mousse et le lichen' and he knows (somehow) that Sancher is responsible for his ancestor's crime: 'A chaque fois que je le rencontre, le regard de mes yeux brûle les siens et il baisse la tête, car ce crime est le sien' (Condé, 1989: 245) [I know where the tortured bodies are buried. I discovered their graves under the moss and lichen [...] Every time I meet him my eyes burn into his, and he lowers his head, for this is his crime (Condé, 1995: 205)]. Thus a direct link is created between the crime of slavery and its punishment, the curse of the dying out of the Sancher lineage.

This revelation is by far the most dramatic moment in Condé's consciously undramatic novel. There is nothing here of the ironic playing down of incest and miscegenation. Instead, the novel puts in place something very similar to Glissant's mimicking of the structure of the 'différé' in order to say something about the original crime of slavery and its present-day repercussions; the 'différé, in other words, once again functions not in relation to the author but on the level of the characters. Thus, throughout Traversée, on the one hand, slavery is rarely mentioned (although there is a brief reference to one of the Lameaulnes ancestors amusing himself by shooting his slaves in the head (Condé, 1989: 124), prefiguring the crime of Sancher's ancestor); while on the other hand, Xantippe's sinister, silent appearances not only frighten Sancher but also make everyone else feel vaguely uneasy. Then in the last chapter, as we finally have access to his interior monologue, Xantippe assumes the more precise role of a reincarnation, a ghost of the slaves, come to Rivière au Sel to avenge their deaths. Thus, an earlier cryptic remark by Sancher about Xantippe - 'ce n'est pas moi qui ai fait couler son sang avant de le pendre à la tête du mapou lélé' (Condé, 1989: 118) [It wasn't me who shed his blood before hanging him from the manjack tree! (Condé, 1995: 91)] - turns out, in the final revelation, to be a reference to the ancestral crime, in which Xantippe also identifies himself with the victims: 'C'est sur les racines en béquilles de ses mapous lélé que la flaque de mon sang a séché. Car un crime s'est commis ici, ici même, dans les temps très anciens' (Condé, 1989: 244) [It was on the buttress roots of its manjack trees that the pool of my blood dried. For a crime was committed here, on this very spot, a long, long time ago (Condé, 1995: 205)]. In other words, the revelation of the ancestral crime of the slave massacre has been foreshadowed all along - we realize in retrospect - by the presence of Xantippe, lurking unacknowledged in the background: as though perhaps not just the massacre but the fact of slavery itself forms a Machereyan unsaid in the novel as a whole, until it finally bursts into the open with Xantippe's revelation. 
Unlike in Absalom, Absalom, however, but as in Le Quatrième Siècle, the ancestral crime in Traversée de la mangrove is in some sense absolved by the end of the novel: Xantippe forgives Sancher on behalf of the slaves whose deaths he would have wanted to avenge: 'Il peut dormir tranquille cependant [... ] je ne lui ferai rien. Le temps de la vengeance est passé’ (Condé, 1989: 245) [He can sleep peacefully though [...] I won't touch him. The time for revenge is over (Condé, 1995: 205)]. One could argue therefore that in Condés novel the atmosphere of damnation which in Faulkner attaches permanently to the ancestral crimes is either absent from the start - incest is a banal misdeed rather than a source of horror and miscegenation is not a crime at all - or in the case of slavery, the curse is lifted.

This would mean seeing Xantippe's act of forgiveness as the equivalent of Le Quatrième Siècle's coming to terms with the past but then moving on, diffusing the sins of filiation in the new historical reality of creolization. But there is, I think, in Traversée de la mangrove - despite Condé's consistent stress on modernity and her refusal of nostalgia - significantly less confidence in the notion of collective historical change. At the end of Le Quatrième Siècle there is a strong sense that things have moved on for the whole community; but in Traversée, because Xantippe's interior monologue is not shared with any of the other characters, both his revelation of the crime of slavery and his act of forgiveness remain purely private; it is impossible to conclude that the community's repression of the collective memory of slavery has been affected - and Xantippe's forgiveness does not, of course, prevent Sancher's death.

Glissant's novel therefore perhaps enacts a more upbeat reworking of its Faulknerian theme, while Condé remains more pessimistic. Both, however, share a focus on slavery as the only original sin that counts - a far more explicit and lucid focus than Faulkner allows himself to have. Both combine the kind of ironic reworking of Faulknerian themes that we have come to expect from postcolonial writers with a perhaps more striking, because less usual, transformation of Faulkner's compulsive need to defer revelation, to 'say without saying', into a controlled representation of the repression of the trauma of slavery; and both, finally, replace the Faulknerian sense of permanent damnation and entrapment in the past with the idea that sins will eventually be absolved - or at least dissolved - and with characters who at least realize the desirability of being able to move on and leave the past behind.

\section{Works Cited}

Bongie, Chris. 1998. Islands and Exiles: The Creole Identities of Post/Colonial Literature. Palo Alto, CA: Stanford University Press. 
Condé, Maryse, 1989. Traversée de la mangrove. Paris: Mercure de France. English translation by Richard Philcox, Crossing the Mangrove, 1995. New York: Anchor Books.

Dash, J. Michael. 1995. Édouard Glissant. Cambridge University Press.

Faulkner, William. 1929. The Sound and the Fury. New York: Jonathan Cape and Harrison Smith.

-. 1930. As I Lay Dying. New York: Jonathan Cape and Harrison Smith.

-. 1936. Absalom, Absalom. New York: Random House.

Glissant, Édouard. 1964. Le Quatrième Siècle. Paris: Éditions du Seuil. Reprinted Paris: Gallimard, 1997. English translation by Betsy Wing, The Fourth Century, 2001. Lincoln and London: University of Nebraska Press.

-. 1981. La Case du commandeur. Paris: Éditions du Seuil. Reprinted Paris: Gallimard, 1997.

-. 1996a. Faulkner, Mississippi. Paris: Stock. English translation by Barbara B. Lewis and Thomas C. Spear, Faulkner, Mississippi, 2000 [1999]. Chicago, IL and London: University of Chicago Press.

—. 1996b. 'Culture et identité'. In Introduction à une poétique du divers. Paris: Gallimard: 59-79.

—. 2007. Mémoires des esclavages. Paris: Gallimard.

Lucey, Michael. 1992. 'Voices. Accounting for the Past: Maryse Condé's Traversée de la mangrove'. In Maryse Condé (ed.), L'Héritage de Caliban. Pointe-à-Pître: Éditions Jasor: 123-32.

Macherey, Pierre. 1966. Pour une théorie de la production littéraire. Paris: Éditions Maspéro.

Pfaff, Françoise. 1996. Conversations with Maryse Condé. Lincoln and London: University of Nebraska Press.

Spivak, Gayatri Chakravorty. 1988. 'Can the Subaltern Speak?'. In C. Nelson and L. Grossberg (eds), Marxism and the Interpretation of Culture. London: Macmillan: 271-313. 


\title{
An American Story
}

\author{
Yanick Lahens ${ }^{1}$
}

1963 - I was twenty years old, the age at which we thrust words taut as fists into the sun's face, when we burn through the days so as not to drag into old age. I had left for America as one summons life, without even waiting for it to beckon. In New York, more than a woman, black, or a student, I was an escapee. I was looking for a way out. Dense thickets still blocked many paths to me when, two years after my arrival, I met Scott Bradley, a black lawyer of the NAACP. In the eyes of exiled Haitians, I became from that moment on a sort of spoils of war to black Americans. Few were those in 1965 who understood that I was going from one anguish to another. And even today I suspect that they didn't want to change the world so much as to Haitianize it, remake it in the image of their own wounds.

Luc must have smiled at me, but I am not sure. Maybe I wanted so badly for it to be thus that I believed it. It was raining, one of those tropical downpours, a straight rain, falling with no reprieve, no pity. I had taken refuge on the porch of the haberdashery where my mother had sent me to buy string. It was the month of September, and she was preparing our uniforms for the start of school in October. Rain in the tropics is always either miracle or upheaval, as if it could not content itself with being ordinary as it did under other skies. And squeezed against each other on that porch, we were already linked by

1 Translated by Nadève Ménard. 
those waters that would just as soon make fruit grow as tear down walls or bury bodies. Joy at the sight was already marred by the imminence of disaster setting its huge dark wings somewhere. But for me, the world still smelled of innocence, and I felt both lost and happy as if in a huge shell of water. And it is perhaps because I thought him as lost and happy as I was that, turning, I saw Luc smile. He was talking to François and smiling. And when he saw that I was looking at him, he stumbled over his words, but continued to smile. In spite of the coolness brought by the rain, I felt a heat wave cross my body from the tips of my toes to the roots of my hair.

As soon as Scott proposed that I accompany him on a trip to the Southern United States, he became haunted night and day by the idea. Without at all suspecting what was hidden behind this obsession, I agreed to the trip with complete confidence. I so wanted to see, and especially to understand. Understand that staunch, obstinate silence with which he met me each time he returned from the South.

Scott had chosen an itinerary, and I was called upon to follow him wherever he wanted with the assurance that he was my guide, my tenacious, sweet and unpredictable brother. Our first stop was Richmond, in Virginia. We were then supposed to go to Atlanta, Georgia, then finally to Birmingham. Through having heard so many stories about the South, fear had started to make its way through my veins each time that Scott had gone there during those last three months. I didn't dare buy newspapers or listen to the radio, and I feared the ring of the telephone. And each time, he returned so broken that often, I didn't know how to start the conversation. I didn't even dare touch him for fear he go off like a charged rifle. For this trip, Scott gave me precise warnings:

First, you make sandwiches, because after Delaware, I'm not stopping at any restaurant, and I'm telling you above all that you will not be calling your aunt or your friend Claudia from our hosts' home. Their phone is tapped.

We made the trip by car. Scott thought it was the best way for me to learn; stopping at the rest stops and seeing for the first time restrooms distinctly marked whites on one side, and blacks on the other. As soon as we left New Jersey, then Newark, I keenly felt the taste of the abyss. I sank into the South. Indeed, you head West, but you sink into the South as though it were an abyss from which a Black person in those years could only return banged up or dead. The South, like a big trap. I leaned out of the window to see better. To 
miss nothing of this pilgrimage. Scott's hand touched the nape of my neck from time to time as if to reassure himself that I was still up for the trip.

It was also out of gratitude. Our first stop was in Delaware to get gas and drink hot coffee. It was the end of spring and we had chosen that time of year so as not to add the additional difficulties of the rigors of winter to a trip that in any case would be no easy journey for two blacks.

At nightfall, we approached Charlottesville where Mr and Mrs Mitchell were supposed to put us up. I had dozed off for a long while, and Scott, seeing me move slightly, woke me up completely with a strange question:

- Listen carefully. Do you hear anything?

After a while, I answered him:

- No!

- I do.

- Really. And what do you hear?

In the distance, cries, moans, groans, the click of a gun, a pack of dogs barking, the sound of boots. This very minute, somewhere in the South, someone is saying to a black man: 'What are you doing here? You know we don't serve Negroes.' At the moment I'm speaking to you, somewhere in the South, someone is killing an innocent. You can't recognize that sound, it's that of the Ku Klux Klan, of the John Birch Society and thousands of voices tracking us in the bushes and high grass.

I realized the extent to which these particular fears had been banished from the roads of my island. If we had other fears to confront, these ones, I knew, had been banished from our roads. We bore only the scars. Today, we witness our own errors, our own grandeur and weaknesses. We pay the price dearly, but they are ours. I myself had thought I'd paid, leaving the island hurriedly one Sunday, fear in my gut, rage in my fists, not knowing too well which one of us, Luc, François or Claude would survive on this road to Birmingham. I felt relieved of my fears, more than I should have been.

Could I have been born in a false paradise? With a sky as blue as a lie above our heads and all around, the violent poetry of the sea.

The monstrous machine began grinding lives. Men in blue uniforms were wearing their first dark glasses, and the DKWs were already rolling in the night, blinding delirious innocents with their headlights. Very quickly, I lost my initial zest for the world: I understood for the first time that this world had its dividing lines. Irreversible ones. That it divided humanity according 
to what you possessed, your sex, your origin, the color of your skin. Faced with this disaster, an unknown anxiety oppressed me. I followed Luc, François and Claude in order to give a name to this distress.

Each day, Luc remade the world and the island in his head. And understanding that all he had left were his tenacity and his dream was difficult for me. The agitation that ruled the universities had largely taken over the high schools, and Luc was no stranger to it. The meeting of the Seniors' association took place at the medical school, and when I got there, Luc was speaking to all of the students. Out loud this time, laying out the reasons why the world was no longer going well. That there was on one side, the rich, and on the other, the poor, the winners and the others. That here, on our island, everything got mixed up from the beginning. That the wheel had turned, dressing the losers of old in the clothing of those who had conquered and humiliated them. Everyone was looking at Luc like he was some sort of oracle, waiting for the words that would save them to fall from his lips. When I got there, Luc turned. His eyes had lost the brightness of the rain. I still wouldn't know how to explain it today. They were burning when he looked at me from the depths of a mystery into which I could not enter, would never enter.

We arrived at our hosts' house at about eight o'clock. On a tree-lined street, we discovered a modest, but cute wooden house. Mr and Mrs Mitchell pulled aside a curtain downstairs to make sure it was us before opening their door. Mr Mitchell was a doctor and Mrs Mitchell a teacher in a nearby school. For a while now, they were being watched because of the ideas they expressed about the emancipation of colored people.

The dinner was full of warmth. Mrs Mitchell, an excellent cook, made us cornbread and honey pork chops. She forced herself to maintain a wise and bitter humor between herself and tragedy, determined to have the upper hand in spite of everything:

- You'd better eat and stock up, because where you're going, people like you and I are not served, past a certain hour. And if God forbid we introduce ourselves to people, well! The whites, they think we've come to kill them, steal from them or rape their wives. So, be very careful! In such difficult situations, I play at being simple and I always end up getting what I want. It is the image of us that suits them most as it reassures them.

She turned to her husband:

- It pisses Jason off. 
- Really! Sometimes Barbara exaggerates.

- Ok, she agreed. But don't I get what I want?

- I have to admit that you do.

- At least it pays off and the white man and I are even. I'm frustrated and he's been tricked.

After the meal, Jason Mitchell wrote on a piece of paper for us the name, address and telephone number of the people who would put us up in Birmingham. And he even drew a map of the city.

We decided not to go to bed too late. Scott had had the idea of interviewing some young blacks the next day. And they were supposed to arrive early in the morning to allow us to leave at the stroke of ten. In fact, they got there at about seven thirty. We waited for them in the kitchen. The youngest was barely sixteen and the oldest was about twenty. What I read in their eyes was the saga of thousands of people freed only to be delivered to a new and incomprehensible nightmare: the nightmare of poverty, hunger, humiliation, crosses burning in the night, blind massacre, and, above all, never-ending fear.

- Are there times in your life when you are not scared?

They were not expecting that question. Perhaps they had never asked it of themselves. So they looked at each other for a moment before answering, almost as one:

- No. All blacks live in fear. Rare are those among the young who have never been arrested or mistreated by the police or by isolated groups of whites.

- It's one thing to know that you have to die one day. We all die. But it's another to know you could be assassinated at any time. I never imagine the future. When the older ones go to work, my father, my brother, I never know if they'll come back whole, or come back at all.

- Fear is within us, it's everywhere. It's like our shadow. Fear is the black man's shadow.

- Why?

- Because that is what America has made of us. We did not choose it.

- Is that why you chose violence? It goes along with fear. They are very similar. Do you think it's normal for people as young as you to live that way?

- You're wrong, we're not young. We've never been young. We are black and that's the main thing. In America, other issues come afterwards. 
Luc had forgotten how to talk to the little people among whom he was born. Those who didn't have the words to express crooked houses, leaking roofs, streets like slimy ponds, illness, epidemics, the lack of love. No words to express deprivation, being packed together, the smell of decaying carcasses, houses burned by the tens. He had wrongly thought that political activism would give him those words. So he gorged himself with words, books, asking himself how such things could be written and said, and unlearned his people's lessons of silence. He now lived apart, painfully distanced, and never wanted to believe it. To believe that man's law could be so terrible.

The next day, the Mitchells walked us to our car and asked us to follow them. They wanted to show us the safest exit out of the city. Just like for our departure from New York, we prepared sandwiches, bought some fruit, filled a thermos with coffee and another with water. As we approached this second phase that was Birmingham, you might as well say that we were approaching Dante's third circle: hell. The mere mention of that city made the hair on every normally constituted black American's head stand up. But for Scott who had lived there, I knew it was a return to something even more profound, something buried in the deepest part of him.

Fatigue numbed us on the road to Birmingham. I felt a sudden dizziness tunneling through my stomach. And I wondered from the depths of what world Scott looked at me. He was sinking towards the South for erasure, to forget. But to forget what? Each instant, I accepted him with his fear, his sighs and his silences. I was following him into the roaring South, into a jungle that became thicker by the second.

The meeting was supposed to be held in a church. Scott was due to speak there. Reverend Williams had opened the doors of his Baptist temple to us, welcoming us with words of encouragement. There were all kinds of people there, mostly blacks, of course. Carl, who had a hard time hiding his violence, his aversion to systems, spoke rapidly. Louis, the Marxist, trying on the contrary, to make everything fit into his system, but getting caught up in a few contradictions, but also some whites like Jonathan or Reverend Williams. While we were in the midst of introductions, a young black man came to warn Reverend Williams that a group of whites from the area had been told about the meeting and were getting ready to respond. Reverend Williams announced the news calmly and added:

- And, of course, the meeting goes on. Besides, tonight, we welcome a 
lawyer who first started out in Chicago and who, today, lives and fights in New York with the NAACP.

I watched Scott stand up. I hadn't realized before how tall he was. He bent his head slightly forward. All heads turned towards him, attentive.

When Scott pronounced these words: 'Good evening, Ladies and Gentlemen, brothers and sisters,' his voice seemed older to me. He didn't say anything that was really new. Nothing that everyone in the room didn't already know. But the content was much less important than the innate power emanating from that voice. It carried the most secret, most intimate challenge and carried far, very far, beyond the streets, the houses, the bloodied bushes around the city:

- What I have to say to you tonight is very simple. I am beating on an open door. Something is changing in the United States of America.

After he spoke for about fifteen minutes, the Reverend advised us to shorten the meeting and to disperse. We did so cautiously in the early part of the Southern night, so surprisingly beautiful and profound. We returned home tired, but happy. The telephone rang at about three o'clock in the morning. It was Reverend Williams announcing that the young black man who had warned us had been beaten to death and had managed to drag himself to his door. He had had just enough strength to knock twice. He succumbed to his wounds an hour later. Scott stayed seated for a long moment. His gaze met mine.

- What are you going to do now?

- I don't know yet. I am sad to death, Jocelyne. And I'm angry. In any case, I am not going to make things any easier for them by bringing myself down. He stayed bent like that and drank a half-bottle of Bourbon in silence. I touched his shoulder.

- God does not exist, if he does I fuck him! ${ }^{2}$

Then, he fell asleep, rage in his heart.

And in that Birmingham night, something became clear. I see us between those four walls. In a warm and cottony silence. The world was nothing but shadows, murmurs, and expectations. Scott turned in his sleep and took on that look of a troubled child that I knew so well. I thought for a moment that he was going to wake up completely. But he opened his eyes a moment, half asleep. I saw his lips tremble, then break into a grimace and I thought

2 Original in English. 
he was going to scream or cry. I almost crushed my hand against his mouth. He placed a tense hand on my forearm and I lessened the pressure.

- Is it you? ${ }^{3}$

- Yes Scott. What's wrong?

He didn't answer that question.

- Stay here, don't leave.

- I'm here Scott. Where would you want me to go?

And, for the first time, unexpectedly, Scott talked. Scott had an implacable memory, vibrant, precise. His voice came from very far away. Hollow and more troubling than all the shadows in this damned town. He blinked, like when you emerge from a dream, and sat up. He pulled apart the edges of that virile wound that he carried within him and that every woman unknowingly awakened:

- My mother was of Trinidadian origin, the daughter of a pastor who had emigrated to the United States. During my childhood, we were poor, but my father was my father and I loved him. I was proud of him. His dirty pants and his old, misshapen hat did not matter to me. No one could play the harmonica like my father, no one could work the land like him. No one walked like him. So straight, so strong. And since I was his eldest son, he talked to me about what we would do, once I had finished school. He told me about the importance of learning at Mr Brown's little school, the town's black teacher. Then, Scott fell silent. For so long that I had to ask another question.

- And then?

I served him some bourbon.

- One day we arrived at a grocery store. It was a Saturday. It was pouring rain. We weren't very clean because we'd spent the day working in the fields. We had never bought from this grocery store. But the next day was my younger brother's birthday, and mom wanted to make him a birthday cake with real icing and asked us to buy some at this grocery store. The door reserved for blacks is on the right, right next to a puddle. And it was raining so hard that particular afternoon that the water came up to our ankles. So, it was raining so hard that we went through the door on the left side that was reserved for whites, with the intention, once inside, of rejoining our ranks. Me, I'm so unused to being in a closed space with

3 Original in English. 
whites that I hesitate in the doorway for a moment. But I still follow my father inside the grocery store. I know that he is the strongest. A lady with a hat and glasses ... . Scott abruptly stopped his story, drank another gulp of alcohol, lit a cigarette, then continued ...

- I will never forget that face. That cow looked at my father and screamed. The other whites stepped back, then turned. The grocer stopped serving clients, came out from behind his counter and grabbed my father by the collar, shook him like a sack of straw and slapped him:

- Didn't you see that there was a door for people like you?

- It's raining and I couldn't use it with my son.

- I don't want to know. Next time, I'll strangle you and I'll tell the cops you threatened me with a knife.

- I watched the scene without being able to budge. I was so ashamed that I was crying in silence. There are several ways to emasculate a man, Jocelyne. Slapping him in front of his son without him being able to react is one of them. Then the grocer shouted:

- Get out!

And he kicked my father to the wet floor. On the way home, I never turned around to look at him, even when he called me with his sad and humiliated voice. My father didn't come home that night and made a habit of crossing our doorstep less and less.

- Other people's childhoods are a foreign land.

- You mean to say that no one can ever enter it?

He didn't answer. Those were the only words he pronounced about the other world, the one over which he seemed to have no control, a world of mystery, the mystery of the vanquished. We were sitting on a small promontory near Fort Jacques. The memory of him in that sun still enchants me. I didn't take him anywhere except to the brink of that childhood. He had nothing to give me except for the sensation of once again being able to set my feet there. While waiting for the one who would stir up his wounds with secret gestures, to better heal them. He turned and I knew in that instant that even when everything had played out in my life there would be the memory of those eyes. He took my face between his hands and placed his lips on mine.

The next day, he had joined François and Claude in hiding. Other worlds were waiting that we would not see together.

It was not until many years later that I learned to weigh that humanity in my hands, according to the more or less ugly things that each person was 
willing to do to exist because suffering is not always redeeming, injustice having long contaminated the heart of the vanquished. Of Luc, François, and Claude, I kept the idea that revolt was still necessary.

I moved close to Scott and laid my head on his shoulder, as distraught as if I was finding him after having lost him for a long time. He crushed his cigarette in the ashtray and slid his dry palms into the warmth of the sheets. Along with pleasure, Scott wanted to find, between a woman's thighs, his childhood intact. The bed fell away from under me and the dizziness carried me even more surely towards him, towards a shared sleep that slowly erased the shame.

1995 - And for several years now, I go over in my memory images of my island, the landscapes of the American South, words of sun and night.

I see Luc's eyes again as though crossed by fires. I still hear Scott's voice, lightly rasped by alcohol and tobacco. I make out the smell of childhood and streams of their hair.

I still have the imprint of their hand in mine, on my skin, gestures that link and unravel. 


\section{Notes on Contributors}

Hugues Azérad is a Fellow in French at Magdalene College, Cambridge. He is the author of L'Univers constelle de Proust, Joyce et Faulkner (Lang, 2002) and co-editor with Peter Collier of Twentieth-Century French Poetry: A Critical Anthology (CUP, 2010). He has written articles and chapters on Reverdy, Proust, Glissant, Faulkner, Nerval and Joyce. He is an editor for the Literary Encyclopedia.

Celia Britton is Emeritus Professor of French and Francophone Literature at University College London, and a Fellow of the British Academy. She has published widely on French Caribbean literature and thought, particularly on the work of Edouard Glissant. Her books include Édouard Glissant and Postcolonial Theory: Strategies of Language and Resistance (1999); Race and the Unconscious: Freudianism in French Caribbean Thought (2002); and The Sense of Community in French Caribbean Fiction (2008). She has also coedited an issue of Paragraph titled 'Francophone Texts and Postcolonial Theory' (2001) and edited 'France's Colonies and the Second World War' (2007), a special issue of Esprit créateur.

Jerome Camal's research focuses on musics of the African diaspora, principally music of the Francophone Caribbean and jazz. He is particularly interested in issues of nationalism and creolization as well as the relationship between music and politics. Other interests include jazz, the connections between North American and Caribbean popular musics, and ethnographic approaches to the study of diasporic consciousness. His dissertation, entitled 
'From Gwoka Modènn to Jazz Ka: Music, Nationalism, and Creolization in Guadeloupe', investigates how gwoka - an African-derived drum music has been deployed and transformed to express changing political ideologies and national identities. By articulating the tension between race and class solidarity as well as between national and diasporic consciousness, this research conceptualizes creolization as a post-nationalist strategy in Caribbean societies. Professor Camal is currently visiting assistant professor of musicology at UCLA.

Mary Gallagher teaches French Studies at University College Dublin. She is the author of La Créolité de Saint-John Perse (Gallimard, 1998) and of Soundings in French Caribbean Writing: The Shock of Space and Time (Oxford, 2002). She has edited or co-edited several volumes directly or indirectly inspired by her interest in the 'Creole problematic', including Ici-Là: Place and Displacement in Caribbean Writing in French (Rodopi, 2003), World Writing: Poetics, Ethics, Globalization (University of Toronto Press, 2008), (with Douglas Smith) a special issue of Modern and Contemporary France on 'Empire and Culture Now' (2010) and (with Michael Brophy) La Migrance à l'oeuvre (Peter Lang, 2011). She is slowly completing a study entitled Lafcadio Hearn's Creole Odyssey and her previously published work on Hearn includes most notably critical re-editions of the French translations of two of his Caribbean-based works: Esquisses martiniquaises (two volumes) and Un voyage d'été aux Tropiques (L'Harmattan, 2004).

Christina Kullberg holds a double PhD in French and Francophone Literature from Uppsala University (2006), and New York University (2009). Her publications include a monograph on Patrick Chamoiseau, Espace urbain et écriture des carrefours, and articles on Édouard Glissant, Maryse Condé, and Magloire-Saint Aude. She has also translated numerous authors from French into Swedish, for example Gilles Deleuze, Édouard Glissant, Jacques Rancière, and most recently, Philippe Hamon. Currently, she works as a researcher at the Department of Modern Languages at Uppsala University, and is directing a network for Caribbean Studies in Scandinavia together with the Department of Romance Studies at the University of Bergen, Norway. She is completing a manuscript on the uses of ethnography in narratives from Martinique; her next project will focus on accounts by French travellers to the Caribbean from the seventeenth and eighteenth centuries.

Yanick Lahens was born in Port-au-Prince, Haiti, in 1953, where she still lives. A novelist and essayist, her published works include Dans la Maison du père (Le Serpent à Plumes, 2000), La Couleur de l'aube (Sabine Wespieser, 
2008; Presses Nationales d'Haïti, 2008), Failles (Sabine Wespieser, 2010), and L'Exil: entre l'ancrage et la fuite, l'écrivain hä̈tien (Éditions Deschamps, 1990).

Jeremy F. Lane is Associate Professor in the Department of French \& Francophone Studies at the University of Nottingham. He is the author of Pierre Bourdieu: A Critical Introduction (Pluto, 2000) and Bourdieu's Politics (Routledge, 2006). He has recently completed the manuscript for a new monograph, provisionally entitled Jazz in the Imperial Metropolis: Music, 'Race', and Aesthetics in Machine-age France.

Typhaine Leservot is Associate Professor in the Romance Languages and Literatures Department (French) and College of Letters at Wesleyan University in Connecticut. She specializes in the intersection of globalization and Francophone postcolonial studies. Her first book, Le Corps mondialisé: Marie Redonnet, Maryse Condé, Assia Djebar, was published by L'Harmattan. She has also published articles on Maryse Condé, Assia Djebar, Marjane Satrapi, and the Muslim veil in Québec. Her current research project focuses on the impact of globalization on Francophone postcolonial theory.

Valérie Loichot is Associate Professor of French and a core member of Comparative Literature at Emory University in Atlanta, Georgia. She is the author of Orphan Narratives: The Postplantation Literature of Faulkner, Morrison, Glissant, and Saint-John Perse (University of Virginia Press, 2007) and The Tropics Bite Back: Literary Cannibalism and Creolization in Caribbean Literature (University of Minnesota Press, forthcoming). Her published articles have dealt with creolization, space, memory, sexuality, exile, cooking and literary cannibalism in the literatures and cultures of the Caribbean and the US South. She has worked on authors such as Édouard Glissant, Edwidge Danticat, Gisèle Pineau, Patrick Chamoiseau, William Faulkner, Octavia Butler, and Lafcadio Hearn.

Martin Munro is Professor of French and Francophone Studies at Florida State University. His recent publications include Different Drummers: Rhythm and Race in the Americas (California, 2010), Edwidge Danticat: A Reader's Guide (Virginia, 2010), and Haiti Rising: Haitian History, Culture, and the Earthquake of 2010 (Liverpool University Press/University of the West Indies Press, 2010). His current projects include books on the theme of the apocalypse in the Caribbean and on the cultural effects of the 2010 earthquake in Haiti. $\mathrm{He}$ is a member of the Small Axe editorial collective. 
Angel Adams Parham has research interests in race, ethnicity, immigration, and culture. She is particularly interested in the way that the movement of people, cultures, and ideas between the American South and the Caribbean have helped to mutually shape social and cultural practices in each region. Her current project, 'American Routes: Legacies of St. Domingue/Haiti in Louisiana', explores the impact of refugees from eighteenth- and nineteenthcentury St. Domingue/Haiti on the racial legacy and cultural heritage of southern Louisiana. Another publication from this project, 'Race, Memory, and Family History', appeared in Social Identities (January 2008). Other work on contemporary Haitian migration has been published in Geographies of the Haitian Diaspora (ed. Regine O. Jackson, 2011) and in various journals.

Jean-Luc Tamby has just defended his doctoral thesis on the musical implications of the work of Édouard Glissant. His publications include 'Le baroque du tout-monde' (the myth of Orpheus in Brazilian music in relation to Edouard Glissant's thought on the Baroque), in L'Education Musicale (May 2009), and 'Le chaos Opéra' (on a collaboration between Édouard Glissant and the multi-instrumentalist Bernard Lubat), forthcoming with the Presses Universitaires de Clermont Ferrand.

Michael Wiedorn is an Assistant Professor of French at the Georgia Institute of Technology. His research focuses on the Martinican novelist and philosopher Édouard Glissant's engagement with the philosopher Gilles Deleuze's work, on the intersections of continental philosophy and Francophone literature more broadly, and on cultural production in the Caribbean and Louisiana. Publications include a collaboration on the entry for 'The Twentieth-Century French Novel' in the Blackwell Encyclopedia of the Novel and a chapter in the book Exils et migrations postcoloniales. Current work includes a history of the notion of creolization in the work of Lafcadio Hearn. 


\section{Index}

Note: The letter ' $\mathrm{f}$ ' indicates a figure and ' $\mathrm{n}$ ' a footnote.

Action française movement 135

Adderley, Cannonball 156

Adorno, Theodor W. 205, 206

aesthetics 106-7, 203n8

African Americans

and créolité 70-4, 172

and Faulkner, William 190

French usage of term 7, 81-2

and jazz 167

and nostalgia 133, 139

Obama, Barack and 90, 91

and racial discrimination 143

African Diaspora 88

Algeria 129, 143-4

American South

Caribbean writers' and artists' relationship with 14-15

Faulkner, William and 185-6, 188

historical trauma of 200-1

Anglo-Americans 60

anthropology

Glissant, Édouard on 105

literariness of 95-6, 97

postmodern 8

Price, Richard: The Convict and the Colonel 95, 97-9 anti-societies 113

Appiah, Kwame Anthony 80

Aribot, Médard see Médard Aribot

Armstrong, Louis 138, 140, 142

Association for the Study of African and Caribbean Literature in French 1

Atlantic triangle 2

autobiography: Price, Richard: The

Convict and the Colonel 95, 97, 99-100

Backès, Jean-Louis 151

Barbados 31

Barthes, Roland 148, 151

beauty 86

Bébel-Gislert, Dany 170n8

bebop 135, 139, 140-1, 143

Benjamin, Walter 197, 208

Bergerot, Franck 159

Berlusconi, Silvio 87

Bernabé, Jean 4, 100

Bernasconi, Robert 131-2

biguine (musical genre) 167, 169

black code see Code noir

Black Music Research Journal 165 
Black Power 114

blackness

Fanon, Frantz 87

Jackson, Michael 86

Obama, Barack 81, 86, 87, 88, 91 see also négritude

Bloch, Ernst: Principle of Hope 206

blues 140-1, 142, 174

Bongie, Chris 219, 222n4

Bonoli, Lorenzo 97, 104

Boulet-Gercourt, Philippe 79

Bourel, Sophie 156

Brecht, Bertolt: Mahagonny 206n14

Britton, Celia

'Eating Their Words' 85, 147

on Glissant, Édouard 177

on langage 149

Bronner, Simon 26

Brooks, Peter 45n4

Brown, James

'Out of Sight' 114

'Papa's Got a Brand New Bag' 114-16

and rhythm 9, 114-15

Buffon, Georges Louis Leclerc, comte de: Discours sur le style 148

Burton, Richard D. E. 173, 176

Cajun/Creole List 74

Camal, Jerome 11

Canboulay 126

Caribbean Creole dialect 32-3

Caribbean Sea 103-4

Carnival 125, 126

Carondelet, François Louis Hector, Governor of Louisiana 50, 51-2

Carpentier, Alejo 191

Césaire, Aimé 3

and Action française 137

Cahier d'un retour au pays natal 15

and langage 191

and négritude 4, 176
Chamoiseau, Patrick

and Créolité movement 4, 100

Un dimanche au cachot $204 \mathrm{n} 10$

Éloge de la Créolité 21

influence 204n10

L'Intraitable beauté du monde: adresse à Barack Obama 88, 90

Lettres créoles: tracées antillaises et continentales de la literature, 1635-1975 19, 20

Quand les murs tombent 177

Charles X, King of France 7

Charpentes (journal) 137

Chateaubriand, François-René: Le

Génie du christianisme 49-50

Chude-Sokei, Louis 81, 91

Cincinatti 23-4, 27, 28, 29, 31

class: 'three-class system' 71

Clifford, James 107

Writing Culture 95-6

Clinton, George 115n1

coartación 59

Code noir 79

Collot, Michel 210n18

colonialism 141-2

Coltrane, John 156, 162

comparative literature 203n9

Condé, Maryse 3

criticism of Creolists 4-5

influence of Faulkner, William 223-5

on Price's The Convict and the Colonel 95, 96

racial identity 216

Traversée de la mangrove 'différé' (repression of truth) 227

linked with Faulkner's As I Lay

Dying 223, 224

filiation 226

guilt 226

incest 225, 227, 228

metaphor 225

slavery $227-8$ 
Confiant, Raphaël

and Créolité movement 4, 100

Éloge de la Créolité 21

'Lafcadio Hearn: The Magnificent

Traveler' 20-1

Lettres créoles: tracées antillaises

et continentales de la littérature,

1635-1975 19, 20

on Obama, Barack 87

‘Pitié pour Michael Jackson’ 86

cosmopolitanism 166

Cowley, John 126n11

'Creole': definition 5, 173

Creole continuum 21

Creole Project 171, 175, 176

'Creoleness' see créolité

Creoles

Americanization 41, 53, 60-1

continuum 20, 33, 38

language $32-3,34,66,67,84$

memory 108

marriage 66

musical culture 119

oral tradition 66,68

parody 126

racial identity $7,64,65,68-70,70-4$

see also free people of colour

créolisation 89, 166, 176

créolistes (Créolité movement) 4-5,

98, 101, 105, 171

créolité

definition 171

Hearn, Lafcadio 21, 36, 38

Kiavué, Klod 172

Murray, David 172

Price, Richard: The Convict and the

Colonel 100

creolization

créolistes and 4, 105

culinary 85-6

Faulkner, William and 185-6

and filiation 223

Glissant, Édouard and 185-6
Guadeloupe 11

Hearn, Lafcadio on 21-2

Martin, Denis-Constant on 168

Martinique 77-8

and métissage contrasted 7, 77,

88-9

of Obama, Barack 7-8, 77-8, 79, 80,91

and race 186

and Relation 91

and rhythm 114-15, 122-7

roots of 165

Crowley, Patrick 185

Cuba 61

culture

and colonialism 141-2

musical 119

and négritude 132-3, 133-4, 168

oral 28

plantation 126

Dahomay, Christian 169

Damas, Léon-Gontron 137, 148

dances: slaves 126

Dash, J. Michael 83n11, 219

Davis, Miles

Birth of the Cool

'Budo' 159

Bitches Brew 153

'Blue in Green' 159

'Footprints' 162

and Glissant, Édouard compared

10-11

influence of 162

'It's About That Time' 160

Kind of Blue 153, 154

and language 147

'Masqualero' 159

Miles Smiles 159

on music 156

Nefertiti 159

and rhythm 156, 158-9, 161-2

spiral 159-60 
So What 155-6, 159

Spanish Key 159

style $148,152-3,154,162-3$

Tutu 157

'Splatch' 156

De Marigny de Mandeville family 37

Debaene, Vincent 96

Déclaration des droits de l'homme et du citoyen (1789) 81

Delaney, Jim 28

Denis, Jacques 171

Depestre, René 119

Deslondes, Charles 51

DeVeaux, Scott 141

Diawara, Manthia 82

'différé' (repression of truth)

Condé, Maryse 227

Faulkner, William 218, 219, 220, 221, 225

Glissant, Édouard 220-1

Domota, Elie 85n13

Doré, Gustave 31

drums

gwoka 169

plantation culture 126

rhythm 117

Roumain, Jacques: Gouverneurs de la rosée 120,122

Williams, Tony 159, 160

Durant, Amelie 72-3

Duras, Claire de: Ourika 51n8

Elder, Jacob D. 126n12

Éloge de la créolité (In Praise of

Creoleness) 4

English language

Barbados 31

Cincinatti 27, 28

New Orleans 32

epic genre 192-3, 201

epidermalization 91

Esprit (journal) 137

ethnographers 26
Fanon, Frantz

Les Damnés de la terre 129, 138,

143-4

filiation 144

and jazz 9-10, 129, 130, 132,

138-40, 141, 144

influence on Obama, Barack 86

Peau noire, masques blancs 129, 131-2, 137-8

and racial identity $87,91,92$,

129-30

'Racisme et culture' 138, 141-3

Faulkner, William

Absolom, Absolom! 200-1, 209,

211n20, 212, 216, 218, 224-5

African American students'

response to 189

As I Lay Dying 223n6

and Condé, Maryse compared

223-8

and creolization 185-6

'différé' (repression of truth) 218, 219, 220, 221, 225

use of epic form 192-3

A Fable 199n3

and filiation 14, 188, 216-17, 223,

224-5

and Glissant, Édouard compared 219

Glissant, Édouard: Faulkner,

Mississippi 11-12, 13, 14, 183,

184-95, 197, 198-212, 216, 219,

220

Go Down Moses 209, 217

guilt 224-5

and history 200

identity 200

influence 191-2

language 187, 190

and literary criticism 198

and miscegenation 217

and modernism 207, 208, 209, 210

and opacity 185, 186, 188, 194 
and otherness 190

use of racial descriptors 79

and Relation 210

and rhythm $211 \mathrm{n} 20$

and slavery 188, 216

The Sound and the Fury 225n8

style 207

and Tout-monde 198, 199n3

tragedy in 192

transgression in $224 \mathrm{n} 7$

translators of $208 \mathrm{n} 16$

the unknown in 209

Figaro (French newspaper) 77, 80

filiation

Condé, Maryse 226

and creolization 223

definition 216-17

Fanon, Frantz 129-30, 144

Faulkner, William 14, 188, 216-17,

223, 224-5

Obama, Barack 89

Foix, Alain 91

Forsdick, Charles 1, 2

Fortier, Alcée 41

France

abolition of slavery 51

Atlantic triangle 2

black community 81

citizenship 81

colonies, former 4

Creoles' connection to 73

discrimination 81-2

extreme right 135

and Louisiana 58, 59

métissage 80

response to Obama, Barack 77, 79,

80, 90-1

Peninsular War (1808) 61

race $81-2$

Vichy regime 137

see also Paris

'Francophone': definition 1-2

Francophone Caribbean Studies 3
Francophone Postcolonial Studies 1-3

Frederiksted (Santa Cruz) 33-4

free people of colour 58, 59-60, 62-3 see also Creoles

French language

Césaire, Aimé 4

Creoles' use of 66, 67

creolization of 21,32

Hearn, Lafcadio 22, 25, 31-2

French Revolution

American fear of 51-2

cultural influences 3

Lussan, Auguste: La Famille créole 6, 47

Frobenius, Leo 132-3

Gallagher, Mary 185n4

genealogy

Louisiana 56, 57

Caribbean and Creole 64-5

Creole and African American 73-4

Creole v. African American 70-3

Creole v. Américain 65-8

Creole v. Black/White racial system $68-70$

methodology 63-4

slaves 219-20

genre 201

Gillespie, Dizzy 135, 141, 148, 154

Gilroy, Paul 173

Glissant, Édouard 3

and aesthetics 203n8

on anthropology 105

'La Barque ouverte' 162

La Case du commandeur 207, $221 \mathrm{n} 2$

Un Champ d'Iles 157-8

La Cohée du Lamentin 152

'Au plus obscur des musiques' 148

and créolisation 88, 166, 168, 186

and Davis, Miles compared 10-11 
Le discours antillais 160-1, 166-7, 176, 183, 199, 200

'L'espace d'une journée' 152 essays 151, 160-1

Faulkner, Mississippi 11-12, 13, 14, 183, 184-95, 197, 198-212, 216, 219, 220

and Faulkner, William compared 219

French knowledge of 210n18

genres 201

Grands chaos 156-7

and Guadeloupe 177

and history 200, 222

and imagination 193-4

Les Indes 160, 162

influence 203-4

L'Intention poétique 160, 200, 210

L'Intraitable beauté du monde:

adresse à Barack Obama 88, 90

and jazz 166-7

and language 147, 184, 191

La Lézarde 205, 211

on literature 209-10

Mahagony 208

Malemort 207

Martinican residence 82

Mémoires des esclavages 221

la mesure and la démesure 157, 158

on métissage 88-9, 168

'Métissage et créolisation' 77

mirroring 201, 207-8, 211

and modernism 13, 118-19, 204-5,

207

and music 147-8

and negation 205-6

Une nouvelle région du monde 203 novels 151

and opacity $183,184,185,188-9$, 203

Ormerod 199n3, 208

and otherness 189
Philosophie de la relation 155, 161, 203

poetry 151-2, 153-4, 208

'Pour Mycea' 158

'Promenoir de la mort seule' 158

use of punctuation 154-5, 157-8

Quand les murs tombent 177

Le Quatrième Siècle 13, 14, 202, 208, 211, 219-20, 220-3, 228

racial identity 216, 219

and realism 13

Relation, poetics of $160-1,166$, 167-8, 177, 189, 202-4, 211

Poétique de la relation 12n1, 147, 161, 168, 185

and rhythm 153-4, 156-7, 161, $211 \mathrm{n} 20$

Sartorius 198

Soleil de la conscience 204

spiral form 160-1

style $148,149,152,154-5,162-3$, 207-8

La Terre inquiète 154

and Tout-monde 168, 188-9, 194, 198-9

Traité du tout-monde 152

Tout-monde (novel) 198, 199n3, $211 n 20$

on trace thought 149-50, 167

on translation $208 \mathrm{n} 16$

on Utopia 206-7

on writers' task 190

Goldhammer, Arthur 79

Goodman, Nelson 151, 161

Gourgouris, Stathis: Does Literature

Think? 195

Grenada 35n20

Guadeloupe

autonomy 84

'Creolization' 11

music 172

gwoka 169, 170, 175

national identity 170,176 
nationalism 173, 176-7

racial identity 224

guilt

Condé, Maryse 226

Faulkner, William 224-5

Gwo-Ka Masters 169, 174, 176

gwoka music 169, 170, 172, 175

and jazz compared 173-4

'gwotet' music 174

Haiti

American occupation 119

cultural dualism 119

modernity 118

music 121

poetry $119-20$

revolution 3

Vodou 117-18, 118-19

see also Saint-Domingue

Hallward, Peter 143

Hamon, Philippe 107

Hanger, Kimberly S. 52

Harlem Renaissance 168

Harrap's Dictionary: definition of métis 78

Harris, Wilson 191

Hawaii 84

Hearn, Lafcadio

'American Period' 22-3

anthropological/ethnological paradigm 26

'At the Gate of the Tropics' 33

on Barbados 31

'Black Varieties' 30

'Les Chiffonniers' 31

Chita 24, 28

'The City of the South' 31-2, 36

Creole folktales 25

créolité 8, 20-3, 35-7, 38

'Los criollos' 21

francophilia 22, 31

identity 19,23

journalism 23-4, 31
Lafcadio Hearn's America: Ethnographic Sketches and Editorials 26

'Levee Life' 28, 30

literary trajectory in America 23-5

Martinique Sketches 25, 28

'Memphis to New Orleans' 25, 33

métissage, aesthetics of 29-32

A Midsummer Trip to the Tropics

25, 33-5, 37

and oral culture 28

and otherness 27

'Pariah People' 29, 31

proto-ethnographic work 24

song transcriptions 28

Two Years in the French West Indies 20-1, 25

'A Winter Journey to Japan' 25

Youma 25, 28

Hearn, Richard 22

history

Faulkner, William and 200

Glissant, Édouard and 200, 222

Martinique 108

regional 75

Hot Club de France 135

Hughes, Langston 160

Hugo, Victor

Bug-Jargal 51n8

Hernani 45

Hutchings, Vincent 92n14

hybridity 107

identities

'American' 57

black 131, 140

Carnival 125, 126

Condé, Maryse 216

Creoles 7, 60, 64, 68, 69, 73-4

Fanon, Frantz 129-30

Faulkner, William 200, 216

Glissant, Édouard 216

Louisiana 41, 42, 52, 53, 59, 60 
Lussan, Auguste 49

Obama, Barack 7-8, 86-8, 89

slaves $125-6$

see also métissage

idiom 150-1

In Praise of Creoleness 4

incest 224-5, 227, 228

L'Insurgé (French newspaper) 135

Jackson, Michael 86

jazz

choruses $148 \mathrm{n} 3$

Davis, Miles and 10, 152-3, 162

Fanon, Frantz and 9-10, 129, 132,

138-40, 144

Glissant, Édouard on 166-7

guerre du jazz 135-6, 140

and gwoka compared 173-4

modern (bebop) 135, 139, 140-1,

143,144

New Orleans 135, 139, 140

and racial purity 135

Senghor, Léopold Sédar and 132, 134

spread of 166

Jean, Alain 173

Jefferson, Thomas 50

jeunes maurrassiens 135

Johnson, Jerah 60

Kemedjio, Cilas 193

Kiavué, Klod 168-9, 173-4, 175

on créolité 172-3

King, Desmond 92n14

Konket, Guy 169

LA Creole 63

Lachance, Paul 61, 62

Ladd, Barbara 200

Ladrezeau, François 175

Lafontaine, Marie-Céline 170n8

Lalande, André 153

land: settlers' appropriation of 217 langage 149-50, 184

language

Barbados 31

Cincinnati 27, 28

Creole 32-3, 34, 85

English 27, 28, 31, 32

Faulkner, William 12, 187, 190

French

Césaire, Aimé 4

Creoles 66, 67

Creolization 21, 32

Hearn, Lafcadio 22, 25, 31-2

New Orleans 32-3

patois 37

Santa Cruz 34

Spanish 21-2

Latrobe, Benjamin Henry 57, 60

Le Diamant (Martinique) 102

Anse Cafard Memorial 82-3, 84f

election (1925) 97

Rue Barack Obama 82, 83

legitimacy 201

Locke, Alain 150

Lockel, Gérard 170, 171

Loi de laïcité (1905) 81

Louisiana 3

Americanization of 52, 60, 62

coartación 59

attachment to France 3

genealogical research

Caribbean and Creole 64-5

Creole and African American 73-4

Creole v. African American 70-3

Creole v. Américain 65-8

Creole v. Black/White racial system $68-70$

methodology 63-4

identity politics 41, 42, 53

Lussan, Auguste: La Famille créole $48-52$

plaçage 58,59

race $7,58,59-61$ 
revolution (1768) 41

slave rebellion (1795) 50-1

theatres 41

see also New Orleans

Louisiana Purchase (1803) 60

Lubat, Bernard 148

Lussan, Auguste

La Famille créole 6

colonial life 43, 45-6

emotions 44-5, 49

French Revolution 6, 47-8

identity politics 49

as melodrama 41, 45, 53

Paris 42, 45, 46, 47-8

political issues $50,51,52,53$

slavery 51

identity 41

Les Martyrs de la Louisiane 41 mirroring 48

lyric genre 201

Mabry, Marcus 79n6

Macey, David 9-10, 129, 130, 138

Macherey, Pierre: Pour une théorie de la production littéraire 218-19

Mangeon, Anthony 150

Maritain, Jacques 136-7

Art et scolastique 136

marriages, mixed 58, 65-6 see also plaçage

Marsh, Dave 115, 116

Marshall, Bill 3

Martin, Denis-Constant 165, 166, 167-8

Martinique

anthropology 95, 97-9

autonomy 84

Creole aesthetic 35

Creole dialect 32-3

créolistes $98 \mathrm{n} 1$

Créolité 4-5

creolization of Obama, Barack 7-8, $77-8,83,84$

Diamond Rock 83n11, 84f attachment to France 125

Hearn, Lafcadio and 26, 28-9

history 108

Lyannaj Kont Pwofitasyon (Union

Against Profit) 85n13

see also Le Diamant; Petite-Anse;

St Pierre

Maulpoix, Jean-Michel 210n18

Maurras, Charles 135, 136

Médard Aribot 95, 97, 101, 102, 103, 108

memory: Price, Richard: The Convict and the Colonel 108

la mesure and la démesure

[moderation and excess]

Davis, Miles 159

Glissant, Édouard 157, 158

metaphors

Condé, Maryse 225

culinary 85

Glissant, Édouard 151

métis: definition 77, 78, 79, 80

métissage

and Creolization contrasted 7, 77, 88-9

Hearn, Lafcadio and 29-32

and multiculturalism 80

Obama, Barack and 79, 80, 82

and Relation 167-8

Métraux, Alfred 117

Miller, Christopher L.: The French

Atlantic Triangle: Literature and

Culture of the Slave Trade 2-3

Mintz, Sidney: Caribbean Contours 5

Miró, Governor 52

mirroring 3

Glissant, Édouard 201, 207-8, 211

Lussan, Auguste 48

Price, Richard 97

racial labels 72

miscegenation

aesthetics of 29

Condé, Maryse and 224 
Faulkner, William and 217, 225

and filiation 216

illegality of 88

and métissage contrasted 79

mixed marriages 66

modernism

Faulkner, William and 207, 208, 209, 210

Glissant, Édouard and 13, 118-19, 204-5, 207

and knowledge 208

Molinié, George 156

Le Monde (French newspaper) 81

Monk, Thelonius 135, 161-2

Montray Kreyol (website) 87

Mounier, Emmanuel 137

mulâtres ('mulattos') 79

Murphy, David 1, 2

Murray, David

Creole Project 171, 175, 176

and créolité 172

and Kiavué, Klod 168-9, 173-4

musicianship 174-5

music 167

African American 166, 171

biguine 167, 169

blues 140-1, 142, 174

Creole 119

Davis, Miles on 156

funk 115

Glissant, Édouard and 147-8

Guadeloupe 169, 170, 172

gwoka 169, 170, 172, 173-4, 175

'gwotet' 174

improvisation 162

and literature 151

nègre 134

quadrille 169

rap 156

slaves and 9, 142, 150

and style 148

world 174

see also jazz; rhythm; songs
Nattiez, Jean-Jacques 175

Nau, Émile 118

Négoce (accordionist) 176

'nègre culture' 132-3, 133-4

Negrit, Frederic 169

négritude

Créolité movement's challenge to 4 and culture 168

Fanon, Frantz and 137

Guadeloupe 177

Sartre, Jean-Paul and 143n8

Senghor, Léopold Sédar and 10, 130

see also blackness

Nesbitt, Nick 118

New Orleans

cultural intolerance 60

French Theater 42

genealogical research see under

Louisiana

Hearn, Lafcadio on 21, 24, 26, 27, $28,30-1,31-2,33,35-7$

history 57

incorporation $65 \mathrm{n} 5$

language $32-3$

municipalities 67

racial identity $35,56,58-9$

refugees $7,40,46,50,53,56,61-3$

see also Louisiana

New York Times 81

Newton, Lewis William 41

nostalgia 100, 133, 139

Le Nouvel Observateur (French

newspaper) 79

Obama, Barack

and African Diaspora 88

creolization 7-8, 77-8, 79, 80, 91

election campaign $92 \mathrm{n} 14$

filiation 89

racial identity $7-8,86-8,89-90$

France $78,79,80,82,90-1$

Martinique 77-8, 83, 91 
'Obama martiniquais' (video) 84-6

Ohio 27, 30 see also Cincinnati

'One-Drop Rule' 79

opacity

Faulkner, William 185, 186, 188, 194

Glissant, Édouard 183, 184, 185, 188-9, 203

oral culture 28, 66

O’Reilly, Alejandro 59

'original sin' 217, 219

otherness 27, 189, 190

Panassié, Hugues 137, 139

Le jazz hot 134, 135, 136

Paris 42, 45, 46, 47-8, 49

Parker, Charlie 135

Pavel, Thomas 107

Peninsular War (1808) 61

Pétion, Alexandre 121

Petit Robert (dictionary): definition of 'créole' 173

Petite-Anse (Martinique) 98-9, 100, 101, 104n2

Pettigrew, Thomas 92n14

Pitot, Jean (James) 65, 66

Pitot House, Bayou St John 66

plaçage 58,59

plantations 3, 33, 113

poetics $203 n 8$

poetry

Glissant, Édouard on 208

Haitian 119-20

'postcolonial': definition 1

Pratt, Mary Louise 25-6

Price, Richard

The Convict and the Colonel 8-9 anthropology 96, 97-9

autobiography 95, 97, 99-100

créolité 100

distancing 101

fiction 96, 103, 104

French translation $108 \mathrm{n} 5$ hybridity $107-8$

literary technique 107

memory 108

methodology 105

mirroring 97

nostalgia 100

style 101-3, 104-5, 105-6

créolistes' criticism of 98

First Time: The Historical Vision of an Afro-American People 96

mirroring 97

reputation 99

'Shadowboxing in the Mangrove' 99

Price, Sally 98

Caribbean Contours 5

'Shadowboxing in the Mangrove' 99

Price-Mars, Jean 119

quadrille (musical genre) 169

race

and Creolization 186

France 81

Louisiana 58-61

and rhythm 125

race hatred 233-4, 238

racial discrimination

France 81-2

United States 91n14, 231, 232, 235, 237-8

racial mixing 56, 216 see also

métissage; miscegenation

racial oppression 143-4

racial prejudice 73

racial segregation 71

racial violence 92n14, 236

racism

colonial 141-2

and métissage 79, 80, 91

Rancière, Jacques 205n12

rap music 156

refugees: New Orleans 7, 40, 46, 50,

$53,61-3$ 
Relation

and créolisation 168, 176

ethnography of 105

Faulkner, William 194, 210

Glissant, Édouard 160-1, 166, 167, 177, 189, 202-4, 211

Obama, Barack 89-90, 91

revolutions

America 15

France 3, 6, 47

Haiti 3

Louisiana 41

rhythm 114, 116

Saint-Domingue 6, 40, 44

rhythm 134

aesthetic 156

Brown, James 114-15

and change 127

and creolization 122-7

Davis, Miles 156, 158-9, 161-2

Faulkner, William 211n20

Glissant, Édouard 153-4, 156-7, 161, 211n20

Haiti 117-22

Lalande, André on 153

music and poetry 151

and race 125

Roumain, Jacques 120-1, 122

Sauvenet, Pierre on 153

slaves 113, 121

spiral form

Davis, Miles 159-60

Glissant, Édouard 160-1

Zobel, Joseph 122-4, 125

Rollins, Sonny 154

Romantics, French 51

Rose, Cynthia 115n1

Rosen, Charles 148

Roumain, Jacques: Gouverneurs

de la rosée 120-2

Rousselin, Pierre 77

Rueff, Martin 210n18
Saint-Domingue (Haiti)

Lussan, Auguste: La Famille créole 43-5

refugees from $7,40,46,61-3$

revolution $6,40,44,61$

slave uprising 40, 50, 61

Saint-Domingue Special Interest

Group 63

St Pierre (Martinique) 34-5

Santa Cruz see Frederiksted

Sartre, Jean-Paul: 'Orphée noir' 143n8

Sauvenet, Pierre 153

Schnepel, Ellen 170n8

Schwarz-Bart, Jacques 175n16

Senghor, Léopold Sédar

'Ce que l'homme noir apporte' 131, $132,134,140$

and jazz 132, 134

and négritude 10, 130

politics of 137

sexual relationships, interracial 58 see also métissage; miscegenation

slave trade 2-3, 162

slavery

abolition of 51

'abyss' of 13

Condé, Maryse: Traversée de la mangrove 227-8

and creolization 14

and cultural erasure 172

Faulkner, William and 188

Hearn, Lafcadio on 22, 28

Youma 25

Obama family's inheritence of 89-90

as 'original sin' 217

and plaçage 58

slaves

and Americanization process $60-1$

and coartación 58

dances 126

former 27, 29, 30, 58

genealogies 219-20 
and identity $125-6$

language 12, 37

and métissage 79

and music 9, 142, 150

New Orleans 60

and rhythm 113, 121

complicity in slavery 220, 221

uprisings 40, 50-1, 61

whites' parody of 126

Smith, Rogers M. 92n14

songs: Lafcadio Hearn's transcriptions

28

Souriau, Etienne 148

Spain 58-60, 61

Spanish language 21-2

Staiger, Emil: Basic Concepts of Poetics $201 n 6$

Strobel, Michèle-Baj: Les Gens de l'or 106

Stuempfle, Stephen 126n13

style

Barthes, Roland on 151

and content 107

Davis, Miles 152-3, 154, 162-3

Faulkner, William 207

Glissant, Édouard 148, 149, 152, $154-5,162-3,207-8$

Goodman, Nelson on 151, 161

Price, Richard 101-3, 104-5, 105-6

Sue, Eugène 31

swaré léwòz (outdoor celebrations) 169

Taylor, Timothy 174, 176

theatres 41

'three-class system' 71

Tournès, Ludovic 135

Tout-monde

Faulkner, William 198, 199n3

Glissant, Édouard 168, 177, 188-9, 194, 198-9

traces 3, 149-50, 167, 211-12

Transnational French Studies:
Postcolonialism and

Littérature-Monde 2

travel books 25-6

Treaty of Paris (1763) 58

Trethewey, Natasha 88

Trinidad 125, 126

Trouillot, Lyonel 122

truth, repression of see 'différé'

Turino, Thomas 166, 170

Turner, Nat 51

Ulloa y de la Torre Guiral, Antonio de 59

Utopia 206-7

Valère, Laurent: Anse Cafard

Memorial, Martinique 83, 84f

van Allen Caulfield, Ruby 41-2

Varèse, Edgar 159

Vergès, Françoise 10, 129-30

Monsters and Revolutionaries 80

Vesey, Denmark 51

Vignes, Luc Michaux 175

Vincent, Rickey 115n1

Virginia slave rebellions 50, 51

Vodou 117-19, 121-2

Weil, Kurt: Mahagonny 206n14

Werner, Craig 116n2

whiteness: Creoles and 64, 65, 68-9, 70

whites

and creolization 186

parody of 126

suffering of 188

Wiedorn, Michael 208

Williams, Tony 159, 160

Zé, Tom 171

Zobel, Joseph: La Rue cases-nègres

122-5

zouk music 170

Zuma, Jacob 86 